GEOLOGICAL SURVEY CIRCULAR 833

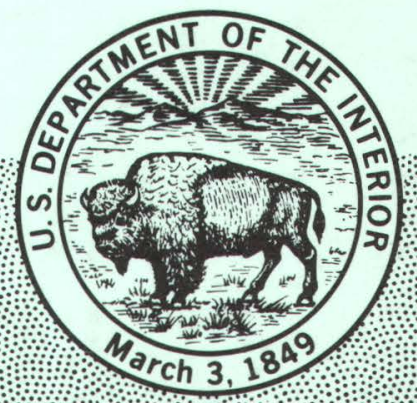

\title{
Geological Studies of the COST No. B-3 Well, \\ United States Mid-Atlantic Continental Slope Area
}



Geological Studies of the

COST No. B-3 Well,

United States Mid-Atlantic

Continental Slope Area

By Peter A. Scholle, Editor

GEOLOGICAL SURVEY CIRCULAR 833 


\section{United States Department of the Interior}

\section{CECIL D. ANDRUS, Secretary}

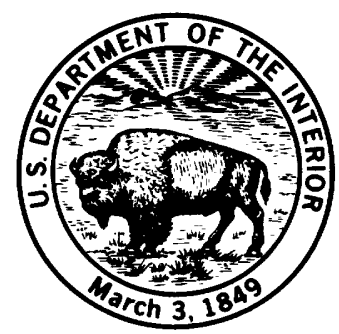

Geological Survey

H. William Menard, Director 
Abstract--

Introduction-_-

Acknowledgments--

Geologic setting and hydrocarbon exploration activity, by Robert E.

Mattick and Kenneth C. Bayer-

Data summary and petroleum potential, by Peter A. Scholle-

Lithology, by Barry M. Pollack-_-

Sandstone petrography, by Barry M. Pollack-_-

Computer well-log analysis, by Ching H. Wu and Renny R. Nichols--------- 26

Foraminiferal stratigraphy, paleoenvironments, and depositional

cycles in the outer Baltimore Canyon trough, by C. Wylie Poag-_-_-

Calcareous nannofossil biostratigraphy, paleoenvironments, and post-

Jurassic continental margin development, by Page C. Valentine--------- 67

Organic geochemistry, by R. E. Miller, D.M. Schultz, G. E. Claypool,

M. A. Smith, H. E. Lerch, D. Ligon, D. K. Owings, and C. Gary-_-_- 85

Geophysical studies, by David J. Taylor and Robert C. Anderson------ 105

Seismic stratigraphy in the vicinity of the COST No. B-3 well, by

John S. Schlee and John A. Grow-

Deep structure and evolution of the Baltimore Canyon trough in the

vicinity of the COST No. B-3 well, by John A. Grow-

Conclusions-_-

References cited--

\section{ILLUSTRATIONS}

2. Isopach map of sediment thickness in the Baltimore Canyon trough area-- 5

3. Geological cross section of Baltimore Canyon trough--_-_--_--- 6

4. Correlation chart of Cretaceous strata of the mid-Atlantic Coastal Plain- 7

5. Generalized stratigraphic section in the Baltimore Canyon trough-- 9

6. Map showing locations of deep exploratory wells drilled in Baltimore Canyon trough-_ 11

7. Generalized lithologies and depositional environments for COST No. B-3 well-_- 14

8. Porosities and permeabilities as a function of depth--_-_-_-_-- 16

9. Comparison of various geochemical and thermal parameters as a function of depth- 17

10. Generalized lithologic plot-_ 21

11-14. Comparison of measured and computed porosities for the interva1:

11. From 9,921 to $9,935 \mathrm{ft}(3,024-3,028 \mathrm{~m})-28$

12. From 11,010 to $11,060 \mathrm{ft}(3,356-3,371 \mathrm{~m})-\ldots$

13. From 12,573 to $12,587 \mathrm{ft}(3,832-3,836 \mathrm{~m})-\ldots$

14. From 13,773 to $13,786 \mathrm{ft}(4,198-4,202 \mathrm{~m})--\ldots$

15-19. Results of computer wel1-1og analysis (SAM7):

15. 8,200 to $10,300 \mathrm{ft}(2,499-3,139 \mathrm{~m})-30$

16. 10,300 to $12,400 \mathrm{ft}(3,139-3,779 \mathrm{~m})-32$

17. 12,400 to $14,100 \mathrm{ft}(3,779-4,297 \mathrm{~m})-34$

18. 14,100 to $15,810 \mathrm{ft}(4,297-4,818 \mathrm{~m})-\ldots$

19. 15,700 to $15,810 \mathrm{ft}(4,785-4,818 \mathrm{~m})-38$ 
22. Index map of stratigraphic drill sites and USGS seismic lines in the outer part of the Baltimore Canyon trough-------- 45

23. Biostratigraphic column, foraminiferal biozones, and paleoenvironments for the COST No. B-3 well-

24. Revised biostratigraphic column, foraminiferal biozones, and paleoenvironments for the COST No. B-2 well- 46

25. Geologic cross section along USGS Seismic Line 25-- 50

26. Paleoenvironmental cross section along USGS Seismic Line 25- 56

27. Lithology, foraminiferal biostratigraphy, and geophysical $10 \mathrm{~g}$ characteristics for the COST No. B-3 well- 58

28. Comparison of sediment accumulation rates at the COST Nos. GE-1, B-2, and B-3 well sites- 61

29. Comparison of global sea-level changes, paleobathymetry, and sediment accumulation rates for the COST Nos. GE-1,

30. Calcareous nannofossil biostratigraphy and paleoenvironments of the $\operatorname{cosT}$ No. B-3 we11

46

31. Summary of organic-richness analyses on $C_{15}+$ hydrocarbon extractables

32.

Gas-chromatographic analyses of saturated paraffin-napthene hydrocarbons of Tertiary rocks-_-

33. Summary of light-hydrocarbon analyses-_-

34-36. Gas-chromatographic analyses of saturated paraffin-napthero hydrocarbons of:

34. Upper Cretaceous rocks- Lower Cretaceous rocks- 95

36. Jurassic rocks--_- 99

37. Summary profile of indicators of types of organic matter present as a function of depth-

38. Maturity profiles of organic matter as a function of depth-

39. Gas-chromatographic analyses of additives to the mud drilling system-

40-42. Filtered and unf
constructed:

40. From interval-transit-time and density logs--

41. Using only velocity data from interval-transit-

time log-- 106

42. Using only density data-_- 107

43. Synthetic seismograms constructed from velocity and

44. Two-way trave1 time as a function of average velocity and root-mean-square velocity-_- 108

45. Two-way travel time as a function of depth-_-_-_-_-_-_-_-_-_- 108

46. Filtered reflection coefficient trace projected into a

portion of USGS seismic Line 25- Interval velocity as a function of depth below sea level
47.

48. Index map of seismic lines and drill holes in the

49. Annotated depth section of a portion of USGS Seismic Line 25 , between shotpoints 2600 and $3400--1$ -

50. Major reflectors distinguished on USGS Seismic L
34, and 35; keyed to relative sea level curve, generalized 1ithology, and biostratigraphic ages--_-_-_-_-_-_-_-

51. Interpretation of USGS Seismic Line 25 depth profile

between shotpoints 1900 and $3900-$
52. Time section of USGS Seismic Line 34 between shotpoints 800 and 1600 
53. Time section of USGS Seismic Line 35 between shotpoints 500 and 1300

54. Map of continental margin off New Jersey with locations of primary structural features and seismic profiles discussed------------_-

55. Structural cross section along USGS Seismic Line 25 between shotpoints 1900 and 3600-_-

56. Annotated multichannel depth section (migrated) for USGS Seismic Line 25 with associated magnetic anomalies-_-_-_-_-_--

57. True-amplitude display (time section) of USGS Seismic Line 25 ltichannel seismic section (Line 2) over the Great Stone Dome--

60. Multichannel seismic section (Line 15) showing two small domes inferred to be salt intrusions-_-

61. Schematic cross section through Baltimore Canyon trough

approximately along Seismic Line 25122
59. Multichannel seismic section (Line 14) over inferred salt diapir--_-_-

Plates 1 and 2.--Light micrographs of selected nannofossils from the $\operatorname{cosT}$ No. B-3 well-

\section{TABLES}

Table 1. Comparison of biostratigraphic analyses from the COST

2. Petrography of selected sandstones from the $\cos T$ No. B-3 well- data for LOGCALC log analysis program-

3. Input data for LOGCALC log analysis program-- Lithologic descriptions of samples used for organic geochemical analysis--

5. Organic carbon and extractable organic matter-

6. Organic-carbon and thermal-analysis data--

7. Analytical data for extractable organic matter in drilling mud additives used in the $\operatorname{COST}$ No. B-3 well-

8. Correlations between the $\operatorname{cosT}$ No. B-3 well and USGS Seismic Line 25 
- 


\title{
Geological Studies of the COST No. B-3 Well, United States Mid-Atlantic Continental Slope Area
}

\author{
By Peter A. Scholle, Editor
}

\section{ABSTRACT}

The CosT No. B-3 well is the first deep stratigraphic test to be drilled on the Continental slope off the Eastern United States. The we11 was drilled in 2,686 ft (819 $\mathrm{m})$ of water in the Baltimore Canyon trough area to a total depth of $15,820 \mathrm{ft}(4,822 \mathrm{~m})$ below the dri11 platform. It penetrated a section composed of mudstones, calcareous mudstones, and 11mestones of generally deep water origin to a depth of about $8,200 \mathrm{ft}(2,500 \mathrm{~m})$ below the drill floor. Light-colored, medium- to coarsegrained sandstones with intercalated gray and brown shales, micritic limestones, and minor coal and dolomite predominate from about 8,200 to $12,300 \mathrm{ft}(2,500$ to $3,750 \mathrm{~m})$. From $12,300 \mathrm{ft}$ $(3,750 \mathrm{~m})$ to the bottom, the section consists of limestones (including oolitic and intraclastic grainstones) with interbedded fine- to mediumgrained sandstones, dark-colored fissile shales, and numerous coal seams.

Biostratigraphic examination has shown that the section down to approximately $6,000 \mathrm{ft}$ $(1,830 \mathrm{~m})$ is Tertiary. The boundary between the Lower and Upper Cretaceous sections is placed between 8,600 and $9,200 \mathrm{ft}(2,620$ and $2,800 \mathrm{~m})$ by various workers. Placement of the JurassicCretaceous boundary shows an even greater range based on different organisms; it is placed variously between 12,250 and 13,450 ft $(3,730$ and $5,000 \mathrm{~m}$ ). The oldest unit penetrated in the well is considered to be Upper Jurassic (Kimmeridgian) by some workers and Middle Jurassic (Callovian) by others. The Lower Cretaceous and Jurassic parts of the section represent nonmarine to shallow-marine shelf sedimentation. Upper Cretaceous and Tertiary untts reflect generally deeper water conditions at the B-3 well site and show a general transition from deposition at shelf to slope water depths.

Examination of cores, well cuttings, and electric logs indicates that potential hydrocarbon-reservoir units are present throughout the Jurassic and Cretaceous section. Porous and moderately permeable limestones and sandstones have been found in the Jurassic section, and significant thicknesses of sandstone with porosities as high as 30 percent and permeabilities in excess of $100 \mathrm{md}$ have been encountered in the Cretaceous interval from about 7,000 to $12,000 \mathrm{ft}(2,130$ to $3,650 \mathrm{~m})$.

Studies of organic geochemistry, vitrinite reflectance, and color alteration of visible organic matter indicate that the Tertiary section, especially in its upper part, contains organic-carbon-rich sediments that are good potential oil source rocks. However, this part of the section is thermally immature and is unlikely to have acted as a source rock anywhere in the area of the B-3 well. The Cretaceous section is generally lean in organic carbon, the organic matter which is present is gen?rally gas-prone, and the interval is thermally immature (although the lowest part of this section is approaching thermal maturity). The deepest part of the well, the Jurassic sention, shows the onset of thermal maturity. The lower half of the Jurassic rocks has high organiccarbon contents with generally gas-prone organic matter. This interval is therefore considered to be an excellent possible gas source; it has a very high methane content.

The combination of gas-prone source rocks, thermal maturity, significant gas shows in the well at 15,750 ft $(4,801 \mathrm{~m})$, and porous reservoir rocks in the deepest parts of tr: well indicate a considerable potential for gas production from the Jurassic section in tha area of the COST No. B-3 well. Wells drilled farther downslope from the B-3 site may encounter more fully marine or deeper marine sections th at may have a greater potential for oll (rather than gas) generation. 


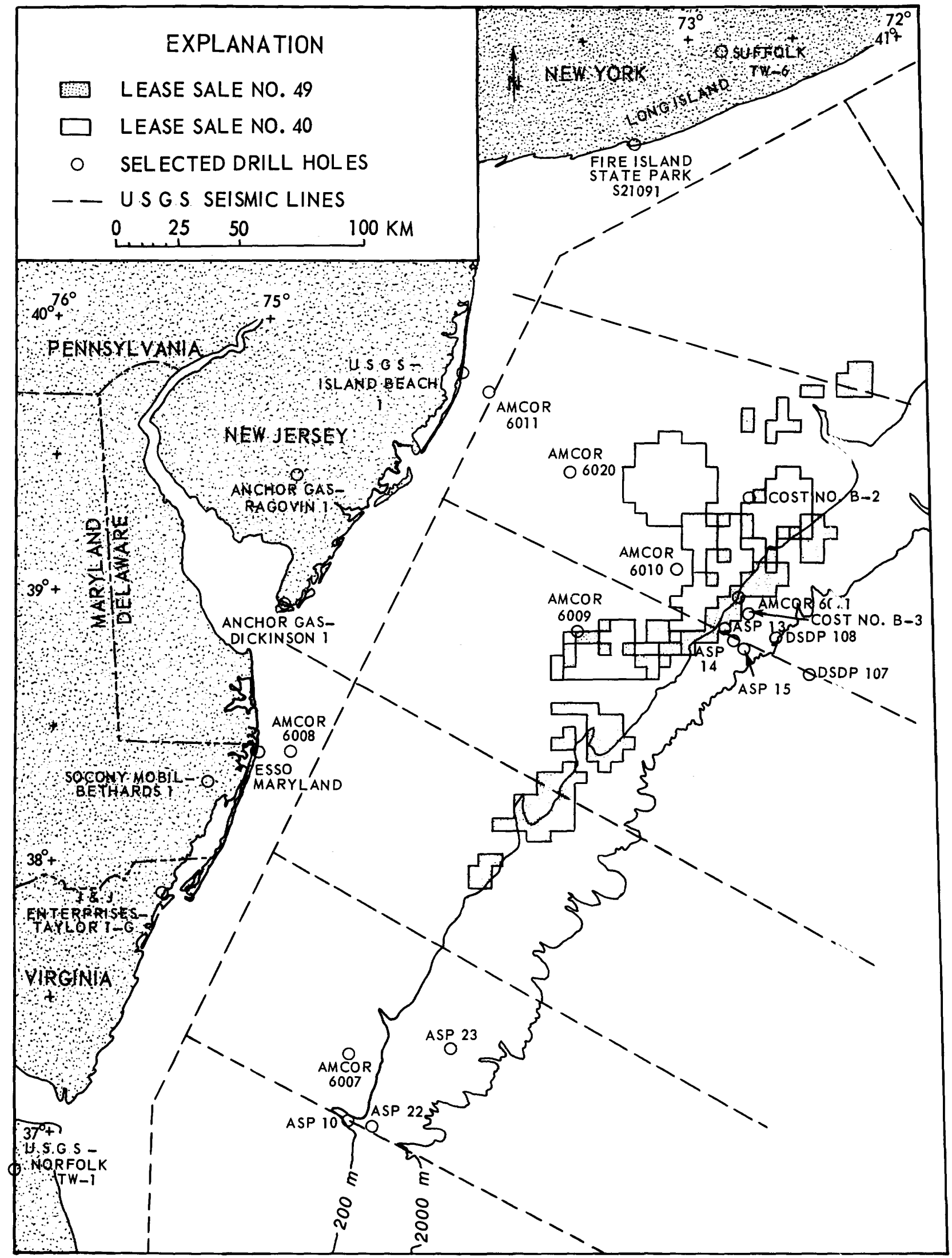




\section{INTRODUCTION}

Until the completion of the cosT (Continental offshore Stratigraphic Test) No. B3 well, the first deep-penetration well to be drilled on the U.S. Atlantic Continental Slope, information about this region was extrapolated from onshore wells, offshore bottom sampling or shallow coring, geophysical surveys, or the COST No. B-2 well (Scholle, 1977), located more than 32 statute miles $(52 \mathrm{~km})$ north of the $\mathrm{B}-3$ site (fig. 1). The COST No. B-3 well was drilled between October 9, 1978, and January 25, 1979, in 2,686 ft $(819 \mathrm{~m})$ of water to examine the petroleum potential of the section seaward of the $\mathrm{B}-2$ well. The well was drilled using the Ben Ocean Lancer, a dynamically positioned dri11 ship, and Chevron USA, Inc. acted as the operator for an 11-company COST-we11 group. The hole was drilled on the present-day Continental Slope, approximately 93 statute miles (150 km) southeast of Atlantic City, N.J. at lat $38^{\circ} 55^{\circ}$ $00.655^{\prime \prime N}$. long $72^{\circ} 46^{\circ} 22.578^{\prime \prime}$. (f1g. 1). The well reached a total depth of $15,820 \mathrm{ft}(4,822$ $m)$ below the Kelly Bushing $(K B)$, equivalent to a penetration of $13,092 \mathrm{ft}(3,990 \mathrm{~m})$ of section below the sea floor. The well is located offstructure but directly adjacent to the area offered for leasing on February 28, 1979, as part of Lease Sale No. 49. The granting of Federal leases within 50 nautical miles $(93 \mathrm{~km}$ ) of the B-3 drill site on May 1, 1979, has made possible the publication of detailed information about the geological findings from the COST No. B-3 well. Leasing stipulations provide for public disclosure by the U.S. Geological Survey (USGS) of all geological information on the well 60 days after such leasing.

Considerable basic operational, lithologic, stratigraphic, and geochemical data, most of it derived from industry reports, have been released previously (Amato and Simonis, 1979). This circular summarizes some of that data and adds information from other studies conducted by the USGS. It is by no means an exhaustive or completed program, but because the COST No. B-3 well has such immediate interest for both the petroleum industry and academic workers, we believe that publication of such preliminary results is justified.
The publication is divided into separately authored sections on geological, geochomical, and geophysical topics. Environmental or operational details are not Included as these have been amply described by Amato and Simonis (1979). A brief synthesis of all available data is presented in the section "Data Summary and Petroleum Potential." Much of the basic data will also be available in chart form (Scholle and others, 1980).

All results reported in this paper were based on analysis of rotary-drill cuttings, supplemented in only a few cases by conventional or sidewall cores. Electric logs ard core descriptions were available, however, to aid in checking the accuracy of sample-depth assignments. The cuttings, in conjunction with electric logs, thus provided a useful picture of the complete spectrum of lithologic variation within a given interval and were commonly more useful than the spot samples provided by sidewall coring. All depth references in this report for electric-log, core, or cuttings data are based on depth below the $K B$, which was $42 \mathrm{ft}$ $(12.8 \mathrm{~m})$ above mean sea level and $2,728 \mathrm{ft}$ (831 m) above the sediment-water interface.

\section{ACKNOWLEDGMENTS}

Technical assistance in sample preparation was provided by Frederick Zihlman. other technical help came from Denise Irlanto, Kim Schwab, Peggy Hempenius, Patty Forreste1, and Doris Low. Raymond E. Hall assisted in analysis of the Neogene planktic faunas, and WiJ.liam $\mathrm{H}$. Abbott analyzed the diatom biostratigraphy and paleoecology in several core holes. William Fairchild and Rod Pickett kindly arranred for the examination of the foraminiferal assemblages from sidewall cores of the COST No. B-3 well. Clyde Kelly and Robert Hohman of Geophysical Services, Inc. provided assistance during all stages of the advanced processing of Line 25, and William Patterson served as the USGS representative during most phases of the acquisition and processing of these data. Page Valentine, John Schlee, C. Wylie Poag, and John Grow read various chapters and provided valuable suggestions. Michael Arthur and Richard Q. Foote reviewed the entire manuscript, an undertaking for which they are greatly thanked.

Figure 1.--Location of selected wells, U.S. Geological Survey seismic-reflection grid, and the lease blocks involved in 011 and Gas Lease Sales No. 40 and 49 in the Baltimore Canyon trough area. Abbreviations used for wells, but not explained in the text, are as follows: DSDP (Deep Sea Drilling Project), ASP (Atlantic slope Project), and AMCOR (Atlantic Margin Coring Project). 
GEOLOGIC SETTING AND HYDROCARBON EXPLORATION ACTIVITY

Robert E. Mattick and Kenneth C. Bayer

The $\cos$ No. B-3 well is located offshore from New Jersey on the present-day Continental slope at a water depth of $2,686 \mathrm{ft}(818.7 \mathrm{~m})$ (f $1 \mathrm{~g} \cdot 1)$.

In this area, basement rocks have subsided to depths of $12 \mathrm{mi}(20 \mathrm{~km})$ with $1 \mathrm{n}$ an elongated, seaward-opening basin called the Baltimore Canyon trough (fig. 2). Analyses of seismic data Indicate that maximum subsidence in the Maryland-Delaware-New Jersey offshore area occurred beneath the Outer Continental Shelf and Slope offshore from New Jersey (f $1 g . \quad 2)$. According to Schlee and others (1979), irregularities in the 1sopach pattern toward Long Island, N.Y., and Cape Hatteras, N.C. reflect a block-faulted basement surface where the basin merges with the Long Island Platform to the northeast and the Carolina Platform to the southwest.

Figure 3 shows a cross section from the Coastal Plain of New Jersey to the COST No. B-3 well. On the Coastal Plain of Virginia, Maryland, Delaware, and New Jersey more than $6,500 \mathrm{ft}(2,000 \mathrm{~m})$ of Mesozolc through Cenozolc sedimentary rocks have been penetrated in numerous wells. These sedimentary rocks lie with marked unconformity on Paleozolc and Precambrian(?) metamorphic rocks and Triassic redbeds, basalts, and intrusives. The oldest post-Triassic sediments drilled on the Coastal Plain north of North Carolina are thin, unfossiliferous conglomerates, arkosic sandstones, and red claystones and shales. The age of these arkosic sandstones and redbeds is controversial (Perry and others, 1975), but they were Identified by Brown and others (1972) as being Jurassic.

The Cretaceous stratigraphy of the Coastal Plain sediments is shown in figure 4. In the Island Beach well (f1g. 3), Lower Cretaceous sedimentary rocks consist almost entirely of fluvial facies containing angular to subangular sandstones, siltstones, and silty claystones of the predominantly nonmarine Potomac Group (Perry and others, 1975). Upper Cretaceous sediments penetrated in the Island Beach well belong to the Raritan and Magothy Formatiors and the Matawan and Monmouth Groups (fig. 4). The Raritan Formation is chiefly of marine origin along coastal New Jersey (Owens and Sohl, 1969). Unconformably overlying the Raritan Formation is the Magothy Formation, which consists of coarse beach sands and interbedded marine and lagoonal deposits (Owens and others, 1968; Owens and Sohl, 1969; Spoljaric, 1972; Perry and others, 1975). The overlying Matawan and Monmouth Groups consist of a cyclic sequence of nearshore-marine deposits (Perry and others, 1975).

Eocene and Paleocene sedimentary rocks on the Coastal Plain of Maryland, Delaware, and New Jersey consist of a sequence of claystones and sandstones of shallow-marine origin (Poag, 1980). In the Island Beach well (fig. 3), oligocene sediments are missing below a major middle Tertiary unconformity (Mrttick and others, 1975). Recent fleld work, however, has revealed that upper oligocene sediments crop out along the Pamunkey and Chlcahoming Rivers in Virginia (Poag, 1980). Miocene sediments consist of shelly sand interspersed with clay beds of shallow- or marginal-marine origin, and post-Miocene strata consist chlefly of coarse to fine, shelly sand and silty clay deposited in nonmarine and marginal-marine ervironments (Poag, 1980).

Comparison of onshore well data with the data from the COST Nos. B-2 and B-3 wells indicates a major thickening, in en offshore direction, of time equivalent rock units-especially Upper Jurassic sediments that are less than $250 \mathrm{ft}(80 \mathrm{~m})$ thick in the Island Beach well and may be more than $4,000 \mathrm{ft}(1,200$ m) thick in the cosT No. B-2 well (f Ig. 3). The seaward increase in section is bolleved to reflect subsidence of basement rocks along a

Figure 2.--Isopach map showing total thickness of sedimentary rocks from sea floor to acoustic basement in the Baltimore Canyon trough region. Contour interval $183,28 \mathrm{C}$ ft (1,000 m). Locations of the selsmic lines, used in compliting the map, are shown in figure 1. 


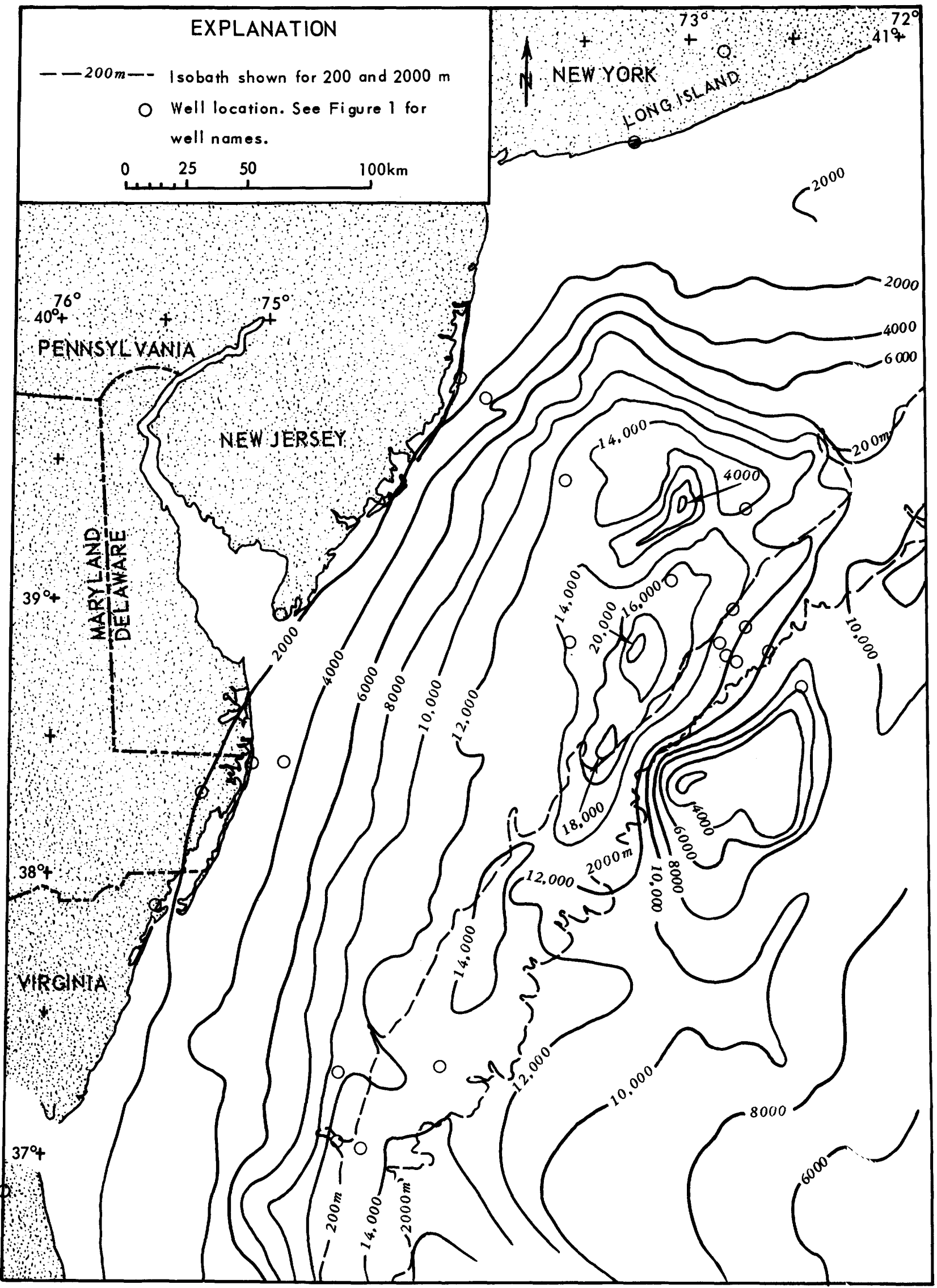




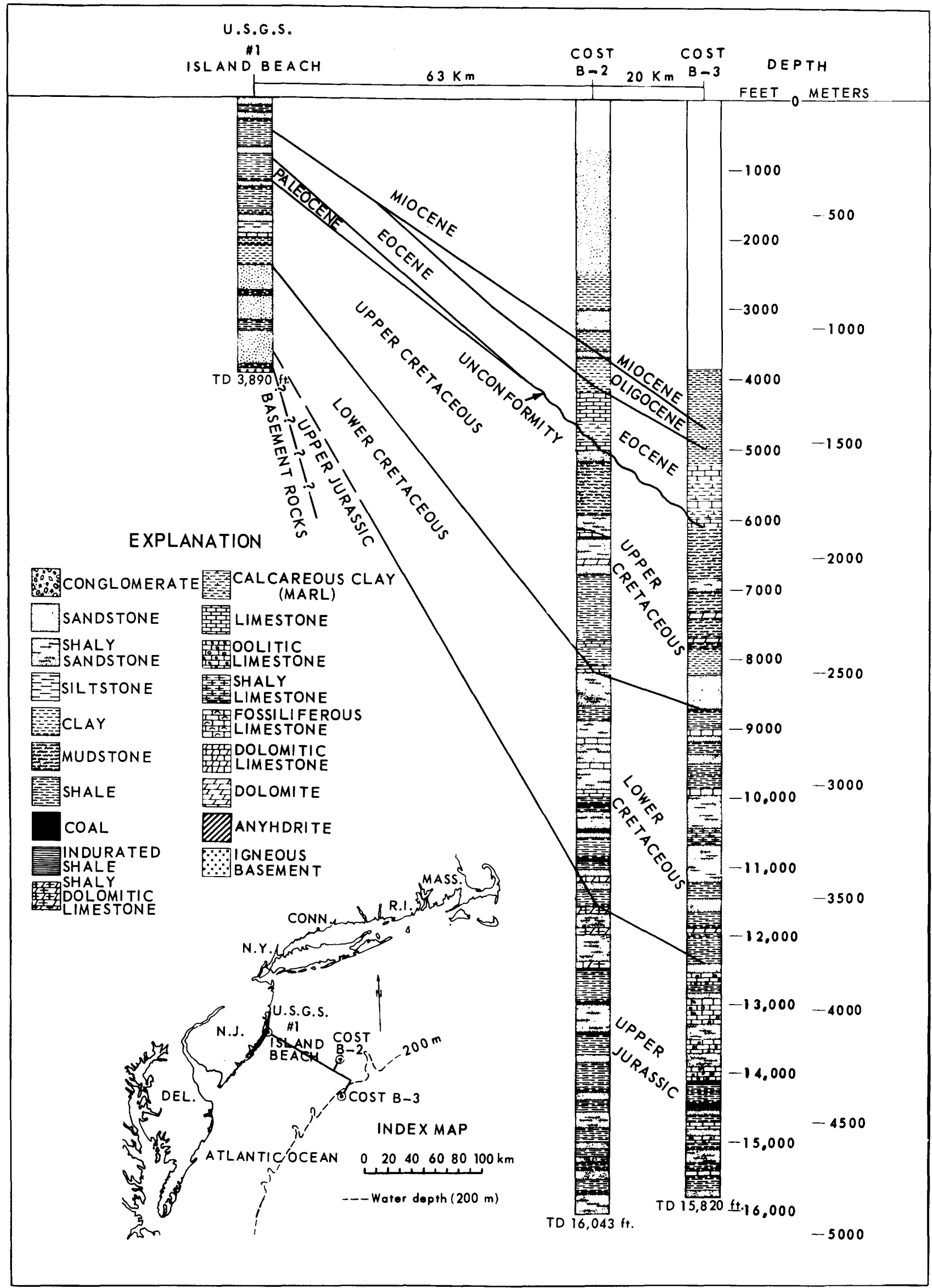


hinge zone located near the coast (Mattick and others, 1974). The greatest subsidence probably occurred during Jurassic time as a hot, young Atlantic rift margin cooled to nearly presentday temperatures.

Time-equivalent rock units, in general, become more marine in an offshore direction. Miocene sands and clays of shallow-marginalmarine origin on the Coastal plain become part of a shelf progradational sequence deposited under deltaic and near-deltaic environments at the B-2 drill site (Poag, 1978). Oligocene deposits, absent on most of the Coastel plain, are represented by claystones deposited in outer shelf environments at the $\mathrm{B}-2$ site (Poag, 1977). Although Eocene and Paleocene deposits reflect a shallow-marine environment in the Island Beach wel1, Eocene deposits fror the B-2 well consist of limestone deposited in water depths equivalent to those of the present-day

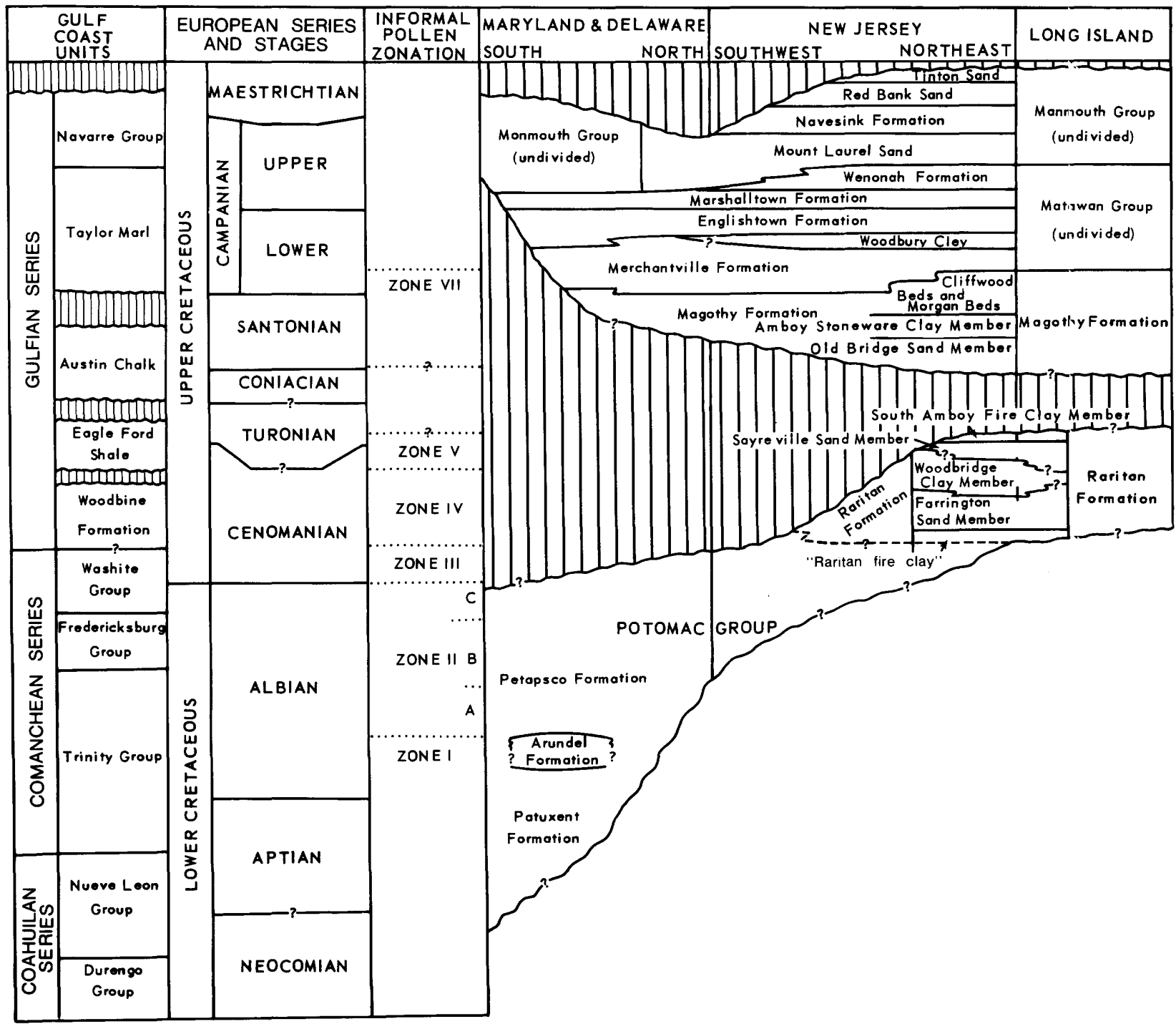

Figure 4.--Correlation chart of outcropping and shallow-subsurface Cretaceous stratigraphic units in Maryland, Delaware, New Jersey, and Long Island, N.Y. From Perry and others (1975).

Figure 3.--Geological cross section of the Baltimore Canyon trough. Modified from Adinolfi and Jacobson (1979, pl. 4). 
Continental Slope (Smith and others, 1976). Upper Cretaceous nearshore shales, beach sandstones, and shales deposited in estuarine to shallow-water environments change to generally marine shales and mudstones (Poag, 1977) deposited in outer shelf environments (Smith and others, 1976) in the direction of the B-2 we11. The Potomac Group is represented by fluvial sandstones on the Coastal Plain; however, during Albian and Aptian time a shallow sea occupied the B-2 site (Poag, 1977). Onshore, basal Lower Cretaceous and Upper Jurassic sedimentary rocks are represented by continental deposits of arkosic sandstones and redbeds. Apparently, during this time, much of what is now the Continental Shelf was at or above sea level and was only intermittently submerged. According to Poag (1977), basal Lower Cretaceous and Jurassic beds at the B-2 site consist primarily of continental deposits, as evidenced by the rare occurrence of marine fossils, abundance of coal beds and terrestrial plant remains, and presence of nonmarine sandstone and shale beds that accumulated under subaerial conditions.

Comparison of data from the $\cos T$ No. B-3 we11 with data from the COST No. B-2 well by Amato and Simonis (1979, p. 111) indicates that the entire section is more marine at the COST No. B-3 well site. Below about $12,400 \mathrm{ft}(3,780$ m) in the COST No. B-3 well, Upper Jurassic sandstone, limestone, shale, and coal were deposited in nearshore-tidal-flat to outer shelf environments (Amato and Simonis, 1979, p. 111). The uppermost part of the sequence also contains oolitic limestone thought to have been deposited in a tidal-bar environment (Schlee, Mattick, and others, 1979, p. 8). During Jurassic time, therefore, the Continental Shelf must have extended farther seaward than the present-day shelf. On the basis of seismic data, Mattick and others (in press) show the Jurassic shelf edge located about $20 \mathrm{mi}(30 \mathrm{~km})$ seaward of its present position.

The pre-Upper Jurassic stratigraphy of the Baltimore Canyon trough is inferred from seismic data (Mattick and others, 1975; Sheridan 1976; Schlee and others, 1976; Mattick and others, 1978; Schlee, Mattick, and others, 1979; Bayer and Mattick, 1980) and by analogy with the Continental Shelf off Nova Scotia on which exploration wells have penetrated Middle Jurassic strata (McIver, 1972; Jansa and Wade, 1975; Given, 1977; Adinolfi and Jacobson, 1979). On the basis of Common Depth Point (CDP) selsmic velocities, the Upper Jurassic clastic sequence penetrated at the bottom of the COST Nos. B-2 and B-3 wells is thought to overlie a thick sequence of Lower Jurassic (or Triassic?) to Middle Jurasilc interbedded limestone, dolomite, and evaporite (including salt) in the basal part of the section. The Houston 011 and Minerals $676-1$ wildcat well penetrated salt at a depth of about $12,500 \mathrm{ft}(3,810 \mathrm{~m})$ in the vicinity of a basaltic(?) intrusion in the central Baltimore Canyon trough area where a thick, uplifted section of Upper Jurassic rocks was removed by erosion. The carbonate-evaporite sequence would correspond 1tthologically and chronostratigraphically to the Iroquois Formation and the salt to the Argo Formation (Adinolfi and Jacobson, 1979). Bcth of these formations have been drilled on the Continental Shelf, offshore from Nova Scotia, Canada. According to Jansa and Wade (1975) and Given (1977), the salt (Argo Formation) was deposited in restricted basins of rift-valley origin, and the dolomite-evaporite sequence (Iroquois Formation) represents a marine transgression prior to the opening of the Atlantic. Bayer and Mattick (1980), however, speculate that the evaporites in the Baltimore Canyon trough were deposited in a narrow, shallow, early Atlantic sea. Internal velocity data s'ggest that shoreward of the COST No. B-2 we11, the limestone, dolomite, and evaporite sequence grades into a clastic sequence of sandstones and shales. This Lower Jurassic (Triassic?) to Middle Jurassic clastic sequence would be equivalent to Mohican Formation penetrated on the Nova Scotia shelf.

Basement rocks underlying the sedimentary wedge in the Baltimore Canyon trough area are thought to be of two types: continental and oceanic. The juncture of these rcck types is belleved to be represented by the East Coast Magnetic Anomaly (Grow and Klitgord, in press, fig. 24), which parallels the Continental Shelf margin in the central Baltimore Canyon trough area; the COST No. B-2 well (fig. 1) lies on or very close to this functure. Oceanic basement rocks (basalts) were presumably emplaced as the African and North American continental plates separated during Triassic or Early Jurassic time. Continental basement rocks a.re probably metamorphic rocks of Paleozolc age. Paleozolc rocks, moderately to strongly metamorphosed, occur east of the Blue Ridge Mountains, in New England, Nova Scotia, and locally in the crystaline Pledmont south of New York. In addition, generally flat-lying Paleozoic sedimentary rocks showing little or no metamorphism are present beneath the Coastal Plain south of Cape Hatteras, North Carolina (Applin, 1951). The continental basement rocks are believed to have been broken up into a series of horsts and grabens during initial phases of rifting, and nonmarine "red beds" were deposited locally in resulting J.ow-standing areas. In outcrop onshore, these rod beds are represented by a heterogeneous mixture of stream and lake deposits plus intrusive ant extrusive volcanic rocks.

A columnar section that summirizes the geology of the Outer Continental Shelf and slope in the Baltimore Canyon trough area is shown in figure 5. Of special interest for the petroleum geologist are possible Mesozolc shelf-edge reef deposits associated with a Jurassic-Lower Cretaceous carbonate bank bulldup. Shelf-edge 


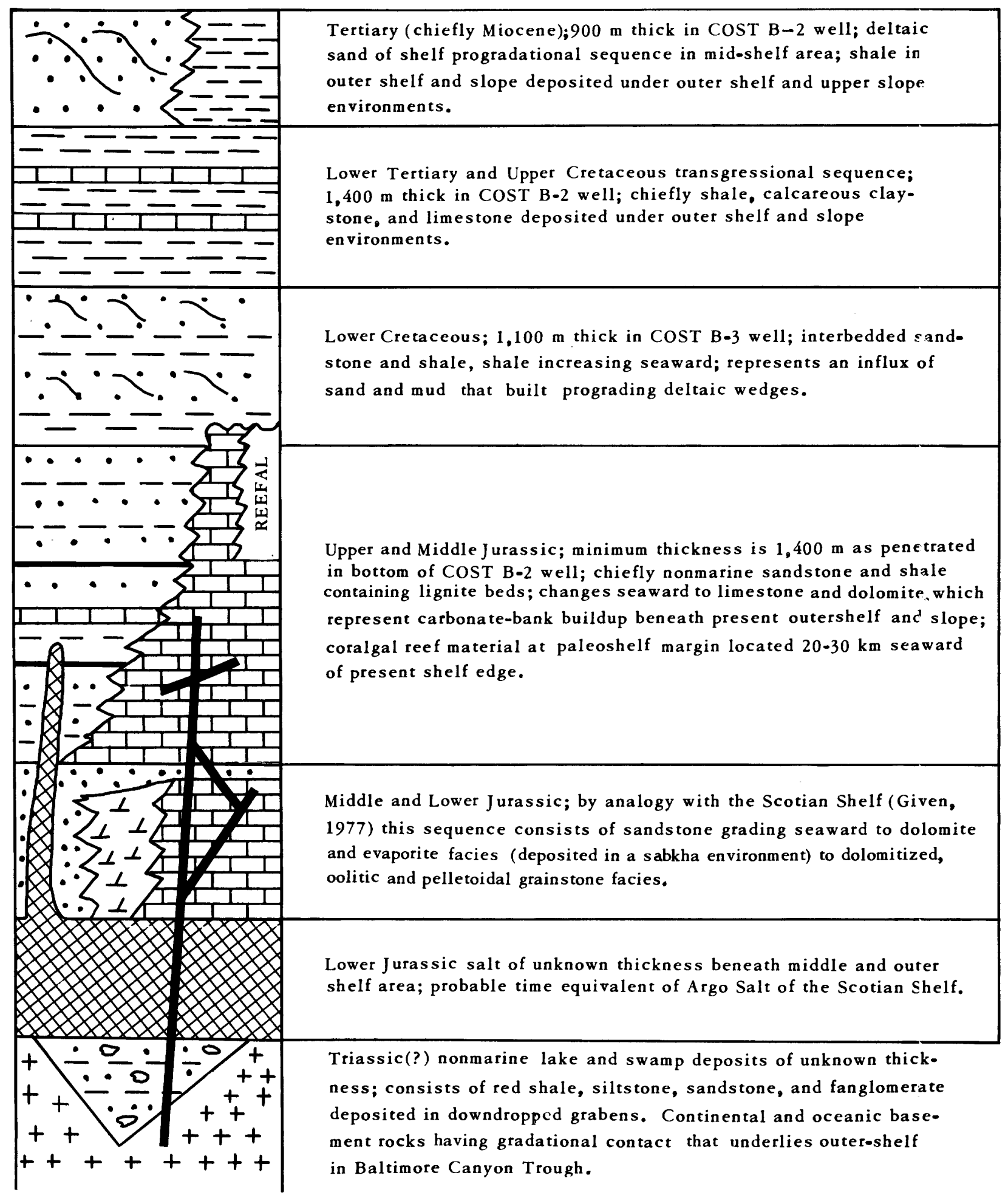

Figure 5.--Generalized columnar section showing lithologic units present and inferred to be present in the Baltimore Canyon trough. Section below the Upper Jurassic is based on geophysical interpretation and analogy with the Continental Shelf offshore from Nova Scotia. Basement intrusions at the shelf margin have been inferred by Schlee, Mattick, and others (1979) on the basis of magnetic interpretation. Other authors have inferred a shallow basement surface at the shelf margin. 
carbonate bulldups were predicted by Mattick and others (1978) on the basis of seismic data. The increase in amount of limestone and dolomite from the $\mathrm{B}-2$ to the $\mathrm{B}-3$ well appears to confirm the interpretation that the Mesozoic shelf margin was dominated by carbonate rocks (Simonis, 1979, p. 104). Petroleum could have been generated in organic-carbon-rich Mesozoic basin facies and have migrated essentially updip, but possibly down section, to reefal reservoir rocks of the Mesozolc shelf margin. Mattick and others (1978) compared the Mesozoic shelf-margin complex to the productive back-reef facies of the Cretaceous Edwards Limestone of Texas and the reef and fore-reef trend of the E1 Abra-Tamaulipas Formation of the Golden Lane and Poza Rica trends in Mexico. However, Simonis (1979, p. 105) noted that this comparison must be tempered by the lack of discoveries in the Upper Jurassic Abenaki Formation (carbonate unit) of the Scotian Shelf in Canada and by the fact that oolitic limestone penetrated in the CosT No. B-3 well had porosities of less than 8 percent and permeabilities of less than $0.1 \mathrm{md}$.

Wildcat drilling in the Baltimore Canyon trough, which started in March 1978, has been concentrated in the vicinity of the Great Stone Dome (fig. 2) and in a narrow strip along the shelf edge. The Great Stone Dome, a large domal structure (f1g. 2) inferred to be assoctated with an Early Cretaceous mafic intrusion, appeared to be the largest and most promising single structure on the shelf. Six wells (fig. 6) were drilled on the structure, and all were plugged and abandoned with no oil or gas shows reported.

Fifteen additional wells, including the two COST wells, have been completed along the shoreward edge of the Continental Shelf (fig. 6). Hydrocarbon shows have been reported from four of these wells. The first discovery was made by Texaco on Block 598. In initial tests, the Texaco 598-1 well flowed natural gas at the rate of 7.5 million $\mathrm{ft}^{3}\left(210,000 \mathrm{~m}^{3}\right)$ per day from a 38-ft $(11.6-\mathrm{m})$ interval below $14,000 \mathrm{ft}$ $(4,270 \mathrm{~m})$; and a second interval of $40 \mathrm{ft}(12.2$ $\mathrm{m})$, below a depth of $13,000 \mathrm{ft}(3,960 \mathrm{~m})$, flowed natural gas at the rate of 9.4 million $\mathrm{ft}^{3}$ $\left(270,000 \mathrm{~m}^{3}\right.$ ) per day (J. C. Hathaway, U.S. Geological Survey, written communication, 1979). A confirmation we11, Texaco's 598-2, located about $1 \mathrm{mi}(1.5 \mathrm{~km})$ west was reported as dry. In May 1979, Tenneco, referring to their 642-2 we11, announced that natural gas flowed from a 14-ft (4.3-m) interval in Jurassic sandstone at about $13,190 \mathrm{ft}(4,020 \mathrm{~m})$; the initial flow rate was 12 million $\mathrm{ft}^{3}(340,000$ $\mathrm{m}^{3}$ ) of natural gas and 100 barrels of condensate per day. Another zone at about $12,650 \mathrm{ft}(3,860$ m) flowed natural gas at the daily rate of 1 million $\mathrm{ft}^{3}\left(28,000 \mathrm{~m}^{3}\right)$ and 500 barrels of salt water. An additional zone at about $8,315 \mathrm{ft}$ $(2,535 \mathrm{~m})$ flowed $48.4^{\circ}$ API gravity oil at the rate of 630 barrels per day from a thin Lower Cretaceous sandstone. In reference to the 642-1 we11, Texaco announced (October, 1579) that it flowed natural gas at a rate 5.5 million $\mathrm{ft}^{3} /$ day $\left(156,000 \mathrm{~m}^{3} /\right.$ day) and condensate at a rate of 18 barrels per day from an interval below $15,480 \mathrm{ft}$ $(4,720 \mathrm{~m})$. Two additional zones, at $12,720 \mathrm{ft}$ $(3,879 \mathrm{~m})$ and $12,990 \mathrm{ft}(3,962 \mathrm{~m})$, were tested in November 1979. The respective daily flow rates were 18.9 million $\mathrm{ft}^{3}\left(536,000 \mathrm{~m}^{3}\right)$ and 14.2 million $\mathrm{ft}^{3}\left(402,000 \mathrm{~m}^{3}\right)$ of natrral gas. A show of natural gas was reported from the COST No. B-3 we11 in the interval from. $15,744 \mathrm{ft}$ $(4,798.8 \mathrm{~m})$ to $15,752 \mathrm{ft}(4,801.2 \mathrm{~m})$ (Scholle, this volume).

Although natural gas shows to date have been significant, a commercial field has yet to be announced. Crawford (1978) has estimated that it would require a daily flow of about 200 million $\mathrm{ft}^{3}\left(5.7 \mathrm{million} \mathrm{m}^{3}\right)$ and reserves of about 1.2 trillion $\mathrm{ft}^{3}$ (34 billion $\mathrm{m}^{3}$ ) of natural gas to establish a profit-ylelding commercial field in the Baltimore Canyon trough. 011 companies may be disappointed by their initial lack of success in the U.S. Atlantic. In August 1976, during the first East Coast offshore sale, industry bid 1.1 billion dollars for the rights to explore 93 (fig. 1) tracts offshore from New Jersey (fig. 1). In February 1979, however, Industry bid only 41.7 million dollars on 44 of 109 (fig. 1) tracts offered for lease in the same area.

Sparce seismic data indicate that the Texaco discovery $(598-1)$ is associated with closure above a pillow (salt?) structure located on the downthrown block of a large growth fault. The strata at discovery depths are complexly faulted. According to Mattick and others (1980), local salt movement on the shelf could be related to movement along growth faults which are oriented parallel to the Continental Shelf and which are common on the shelf margin. Two wells (Exxon's 684-1 and 684-2, fig. 6), drilled on a similar pillow (salt?) structure $9 \mathrm{mi}(15 \mathrm{~km})$ southwest of the Texaco discovery, however, were plugged, abandoned, and reported as dry holes (J. C. Hathaway, U.S. Geological Survey, written communication, 1979).

A summary of the petroleum geolcgy prior to the drilling of the COST No. B-3 well is as follows: Results from seismic aralysis and exploratory drilling have indicated that the shelf margin, as compared to the mid-shelf area, offers better possibilities for further exploratory work. Traps are expected to involve relatively complex structures. Analyses of data from the COST No. B-2 well indicate that conditions for the generation and entrapment of natural gas in Jurassic sediments are favorable (Scholle, 1977, p. 14). On the Continental Shelf, Lower Cretaceous and Jurassic sandstones offer the best reservoir possibilities. The sandstone porosity values are small below 12,000 ft $(3,700 \mathrm{~m})$ because of a breakdown of feldspar and generation of calcite cement (Scholle, 1977, p. 8); but, locally, thin porous sandstone layers persist to depths of at least $16,000 \mathrm{ft}$ 


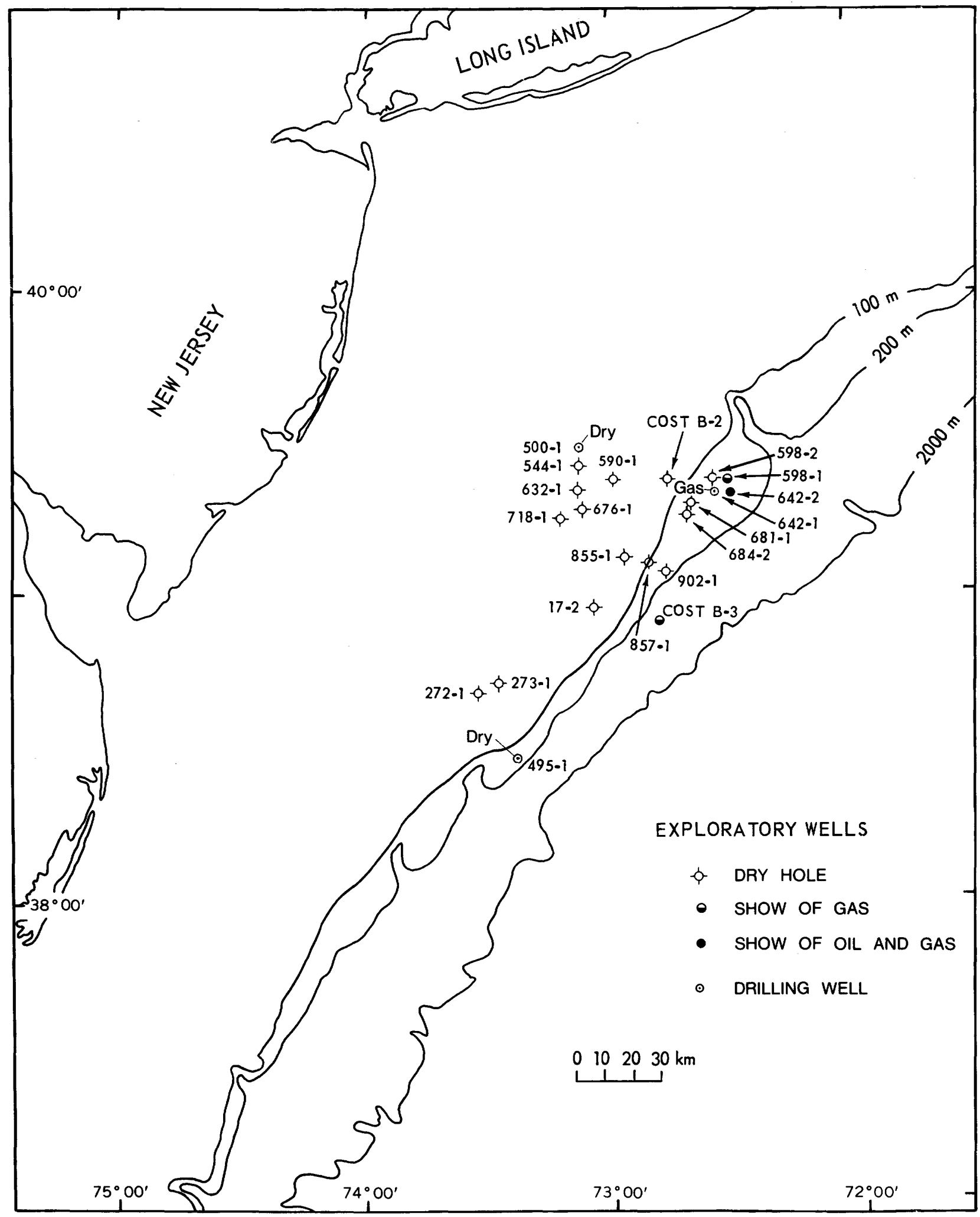

Figure 6.--Locations of deep exploratory wells drilled in the Baltimore Canyon trough. 
$(4,900 \mathrm{~m})$ and these have flowed natural gas in at least two wells. Seismic data suggest that Jurassic carbonate rocks, which could be potential reservolrs, exist at depth on the Continental Slope. Although comparison with the Abenaki Formation (Middle to Late Jurassic age) of the Scotian Shelf would suggest that these carbonate units are usually tight, the Shell Demascota G-32 well, drilled as a shelf-edge test on the Scotlan Shelf, penetrated $551 \mathrm{ft}$ $(168 \mathrm{~m})$ of porous dolomites and limestone (including coralgal reef carbonates) with porosity values as large as 14 percent in the limestone and fracture porosities of unknown magnitude in the dolomite (Given, 1977, p. 74). In addition, on the Scotian Shelf, a variety of porosity types exist in the Iroquois dolomite (Early to Middle Jurassic) with values as large as 15 percent and oll staining reported in several wells (Given, 1977, p. 71). Whether or not such reservolrs are located on the paleoshelf margin in the Baltimore Canyon trough near the lower part of the present slope and whether those reservolrs could have been charged with liquid hydrocarbons generated in nearby basin facies are not known. The discovery of oll in the Tenneco 642-2 well, however, lends some weight to these possibilities. 
DATA SUMMARY AND PETROLEUM POTENTIAL

Peter A. Scholle

The cosT No. B-3 well penetrated 13,092 ft $(3,990 \mathrm{~m})$ of Tertiary to Jurassic section. Lithologic, blostratigraphic, and paleoenvironmental studies, summarized in figure 7 and table 1 , Indicate that the section from 3,810 ft $(1,161 \mathrm{~m})$ (the shallowest sample recovered in this well) to about $6,000 \mathrm{ft}(1,830$ m) consists of Miocene to Eocene calcareous clays, chalks, and shales. The entire interval represents deep-water sedimentation at outermost shelf to lower slope water depths. Nevertheless, significant hiatuses are present below the Eocene, within the 0ligocene, and within or at the base of the Miocene. These presumably reflect submarine rather than subaerial erosional events.

Below a major unconformity at $6,020 \mathrm{ft}$ $(1,835 \mathrm{~m})$ at which the entire Paleocene and part of the Maestrichtian were missing, Upper Cretaceous sediments are present down to a depth of about $9,000 \mathrm{ft}(2,750 \mathrm{~m})$. This section contains calcareous mudstones, glauconitic sandstones, and dolomitic limestones; it shows a progressive change in paleoenvironments of deposition from outer shelf or upper slope depths at the top to Inner shelf or middle-shelf depths at the base. Unconformities have been reported from several horizons within the lower part of this section. The exact placement of the base of the Upper Cretaceous varies among workers. Poag (this volume) places the boundary at $9,170 \mathrm{ft}(2,795 \mathrm{~m})$ on the basis of studies of foraminifers; Valentine (this volume) places it at $8,900 \mathrm{ft}(2,713 \mathrm{~m})$ on the basis of nannofossils; and Steinkraus (1979) placed it at $8,690 \mathrm{ft}(2,649 \mathrm{~m})$ on the basis of a suite of microfloral and microfaunal studies (table 1).

Conformably underlying the Upper Cretaceous section is a thick interval of Lower Cretaceous sediments. These sediments contain interbedded sandy shales, sandstones, and micritic limestones with small amounts of coal, all deposited mainly in inner shelf to margina1marine conditions. One hiatus has been recognized between the Hauterivian and Barremian sections, and it may have involved subaerial exposure (Poag, this volume). The base of the Lower Cretaceous is placed at $12,400 \mathrm{ft}(3,780$ m) by Steinkraus (1979); at $12,260 \mathrm{ft}(3,737 \mathrm{~m})$ by Poag (this volume); and at $13,450 \mathrm{ft}(4,100$ m) by Valentine (this volume). Thus, in the $B-3$ well, as in most wells along the Atlantic margin of the United States, considerable disagreement exists about the exact placement of the Jurassic-Cretaceous boundary.

The underlying section, to the base of the we11 at $15,820 \mathrm{ft}(4,822 \mathrm{~m})$, is considered to be Jurassic. This interval contains shales and sandy shales with interbedded limestones, subordinate sandstones, and coal beds. Deposition was apparently in nonmarins to shallow-marine, inner shelf conditions. Steinkraus (1979) and Valentine (this vclume) identified the entire section to the base of the we1l as Upper Jurassic, but Poag (this vclume) has recognized a Callovian(?) fauna ir the interval from 15,390 to $15,820 \mathrm{ft}(4,691$ to $4,822 \mathrm{~m})$ and thus considers the well to knttom in the Middle(?) Jurassic.

The biostratigraphic results for the COST No. B-3 well, summarized in table 1, indicate close agreement between all workers or the placement of the Cretaceous-Tertiary botndary and the series boundaries within the Tertiary. The disagreement on the placement of other boundaries increases, however, with increasing geologic age. Thus, there is a spread of about $500 \mathrm{ft}(150 \mathrm{~m})$ in the interpretation of the Lower Cretaceous-Upper Cretaceous boundary and a spread of nearly $1,200 \mathrm{ft}(365 \mathrm{~m})$ for the Jurassic-Cretaceous boundary. Better binstratigraphic standards and further studies are needed to reduce such differences.

Sedimentation rates of verious stratigraphic units are discussed by Poag (this volume). Jurassic rates range from 2.1 to 3.1 in. $/ 1,000$ yrs $(5.4$ to $7.8 \mathrm{~cm} / 1,000$ yrs). Rates for the Lower Cretaceous sediments raried between 0.8 and $1.5 \mathrm{in} . / 1,000$ yrs $(2.1$ and 3.8 $\mathrm{cm} / 1,000$ yrs), except in the Valanginian interval which had rates of 2.8 to $3.2 \mathrm{in} . / 1,000$ yrs ( 7.0 to $8.1 \mathrm{~cm} / 1,000$ yrs). Upper Cretrceous sediments were deposited at rates that varied from as low as $0.5 \mathrm{in} . / 1,000$ yrs $(1.3 \mathrm{~cm} / 1,000$ yrs) in the Maestrichtian to as high as 4.1 in. $/ 1,000$ yrs $(10.5 \mathrm{~cm} / 1,000$ yrs $)$ is the Turonfan. Tertiary rates at $\mathrm{B}-3$ range from 0.4 to $1.5 \mathrm{in} . / 1,000$ yrs $(1.0$ to $3.9 \mathrm{~cm} / 1,000 \mathrm{yrs})$, 
PALEOBATHYMETPY

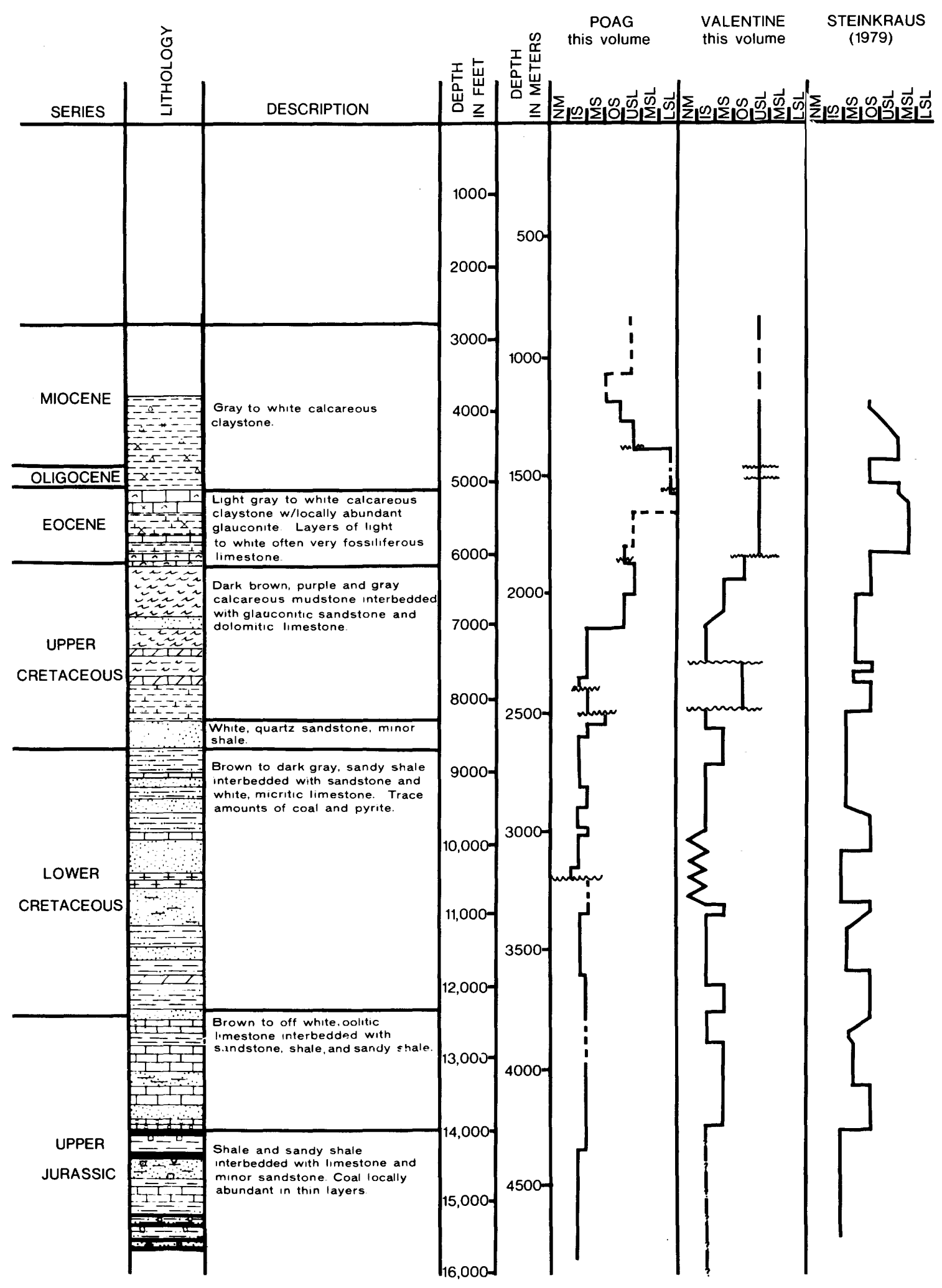


with a significant pulse in the middle Miocene of $3.2 \mathrm{in.} / 1,000 \mathrm{yrs}(8.0 \mathrm{~cm} / 1,000 \mathrm{yrs})$.

The porosity and permeability values of conventional and sidewall core samples from the $\operatorname{cosT}$ No. B-3 well are shown in figure 8. Porosities of units in the Tertlary and Upper Cretaceous section, down to about $8,200 \mathrm{ft}$ $(2,500 \mathrm{~m})$, vary between 20 and 32 percent. Corresponding permeabilities in these relatively fine-grained rocks are small, however. Only about 200 ft $(60 \mathrm{~m})$ of reservolr-quality sandstone was noted in this interval (Amato and Simonis, 1979).

The Cenomanian and Lower Cretaceous Interval between about 8,200 and $11,630 \mathrm{ft}$ $(2,500$ and $3,550 \mathrm{~m})$ contains many more sandstone units, and more than $1,000 \mathrm{ft}(300 \mathrm{~m})$ of sandstones with porosities of 16-24 percent have been reported for this interval (Amato and Simonis, 1979).

The Lower Cretaceous and Upper Jurassic section from $11,630 \mathrm{ft}(3,550 \mathrm{~m})$ to the base of the well at $15,820 \mathrm{ft}(4,822 \mathrm{~m})$ contains thin sandstone units as well as numerous potential limestone reservolrs. Log analysis has defined an interval of approximately $140 \mathrm{ft}(43 \mathrm{~m})$ of sandstone with porosity values greater than 8 percent (Amato and Simonis, 1979). Analysis of sidewall cores has shown even higher porosity values for sandstones in this section, averaging about 20 percent. Corresponding permeabllities, however, are quite small, averaging less than 10 md., a reflection of probable diagenetic alteration of these units involving authigenic clay formation and possible secondary-porosity generation. Carbonate rocks in this basal interval of the well have moderately low porosities, generally below 10 percent, and permeabilities generally below $1 \mathrm{md}$.

Impermeable beds, which could act as seals for hydrocarbon entrapment, are present throughout the section. The thick sequence of calcareous claystones, shales, and chalks from 3,800 to about $6,200 \mathrm{ft}(1,161$ to $1,890 \mathrm{~m})$, as well as thinner shale and Impermeable limestone beds throughout the penetrated section, is the best potential seal. Furthermore, the significant differences in section between the B-3 and B-2 COST wells indicate that considerable lateral interfingering of sandstones and shales (on the landward side) and limestones (on the seaward side) is to be expected in this area. Thus, stratigraphic traps with updip permeability barriers are quite likely in this region.

Temperature logs were not run on the B-3 we11, and so no precise value can be given for the present-day geothermal gradient in this area. Temperature data, taken from headirs of other electric logs (fig. 9) run in this well, show an average geothermal gradiert of $1.26^{\circ} \mathrm{F} / 100 \mathrm{ft}\left(22.8^{\circ} \mathrm{C} / \mathrm{km}\right.$ ) (Amato and Simonis, 1979), which is similar to the value of $1.30^{\circ} \mathrm{F} / 100$ ft $\left(23.7^{\circ} \mathrm{C} / \mathrm{km}\right)$ obtained for the nearby COST No. B-2 well (Scholle, 1977). This relatively low present-day geothermal gradient is also reflected in the rather low rate of thermal maturation of organic matter with depth in the B-3 we11. Two maturation findices (vitrinite reflectance and visual kerogen) are presented in figure 9, and both show that the onset of thermal maturity occurs in the deepest part of the we11, below about $15,000 \mathrm{ft}(4,575$ m).

In general, organic geochemical studies have shown that the Tertiary section in tla COST No. B-3 wel1, down to approximately $6,000 \mathrm{ft}$ $(1,825 \mathrm{~m})$, contains high concentraticns of organic matter (as much as 3 percent, with an average of about 1.5 percent) (Miller and others, this volume). The kerogens in this interval are primarily marine, hydrogen-rich, ofl-prone types that would indicete a significant potential for ofl generation. However, the very low degree of thermal maturation of organic matter in this interval (vitrinite reflectance values of 0.26 to 0.35 percent, and thermal alteration index (TAI) values of 1.2 to 1.5 ; fig. 9) Indicates that this sediment is not likely to act as an actual source rock unless it is much more deeply buried. The shallow gas occurrence in this well at about $4,000 \mathrm{ft}(1,220 \mathrm{~m})$ was predominantly methane of probable biogenic origin.

The Cretaceous interval from approximately 6,000 to $12,400 \mathrm{ft}(1,841$ to $3,780 \mathrm{~m})$ contains dominantly humic, hydrogen-lean, gas-prone, exinite- and vitrinite-type kerogens with atomic hydrogen-to-carbon ratios of 0.6 to 0.8 (M11ler and others, this volume). Total-organic-carbon contents are moderate, averaging under 1 percent. An average carbon preference index (CPI) value of 1.5 , a total hydrocarbon-toextractable-organic-matter ratio of 0.30 to 0.52 , low thermal-pyrolysis values (generally below $436^{\circ} \mathrm{C}$ ), TAI values of 1.51 , and vitrinitereflectance values of 0.35 to 0.39 percent all indicate moderate thermal immaturity for this interval and poor hydrocarbon source potential.

The Jurassic interval from about $12,400 \mathrm{ft}$ $(3,780 \mathrm{~m})$ to the base of the well has organicrichness characteristics that indicate moderate to good source-rock potential. The interval below $14,300 \mathrm{ft}(4,359 \mathrm{~m})$, in particuler, has

Figure 7.--Generalized plot of lithologies and comparison of depositional-environment assignments of sediments in the COST No. B-3 well. Environmental designations are as follow: NM, nonmarine; IS, Inner shelf; OS, outer shelf; USL, upper slope; MSL, middle slope; LSL, lower slope. Age assignments are from Amato and Simonis (1979); 11thologic data from Pollack, this volume. 
CORE POROSITY (percent)

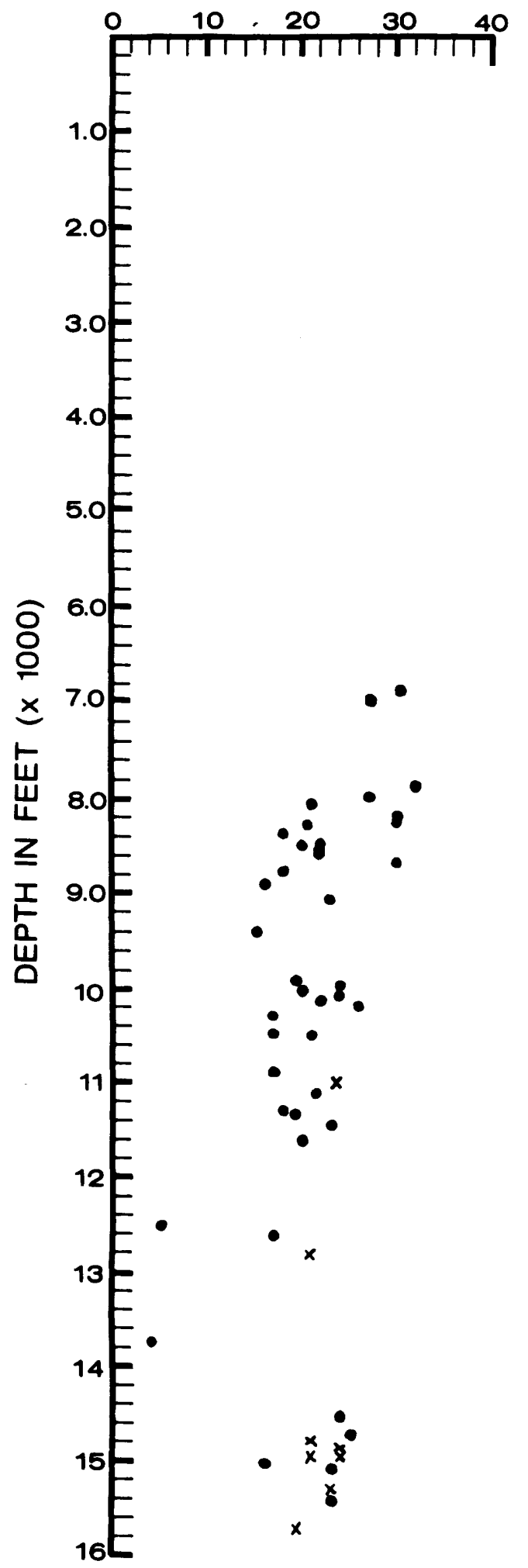

PERMEABILITY (millidarcies)

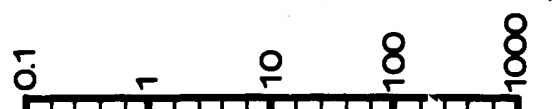

हार्णाता गार्णाता

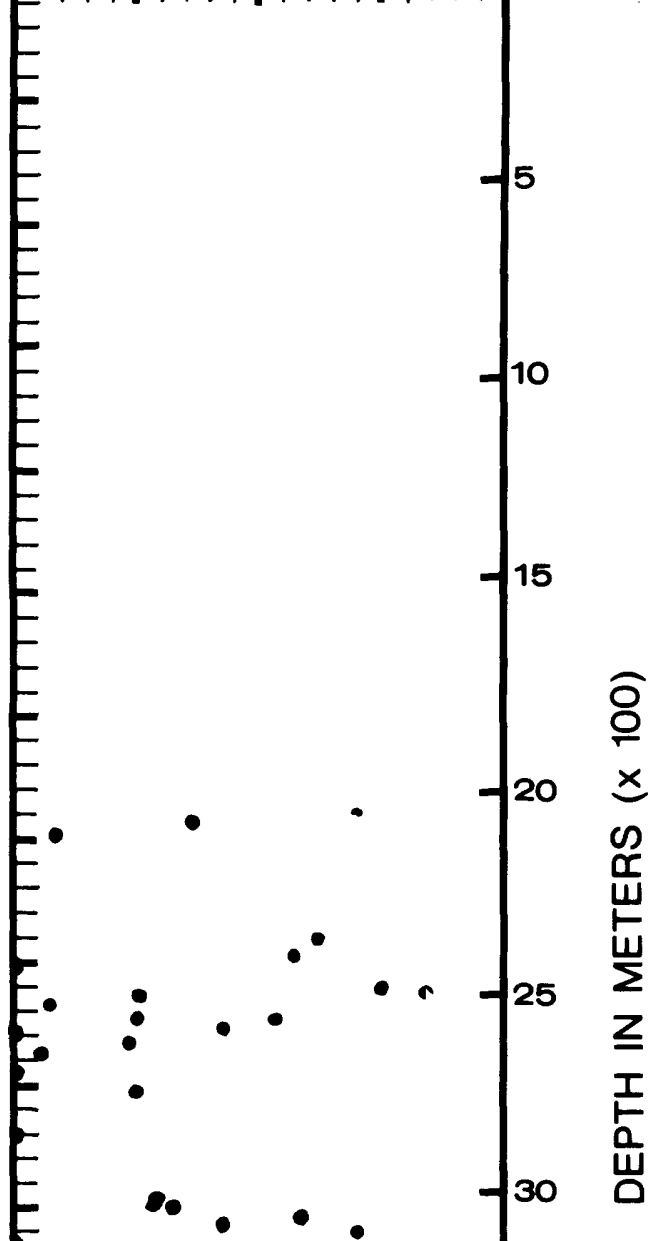

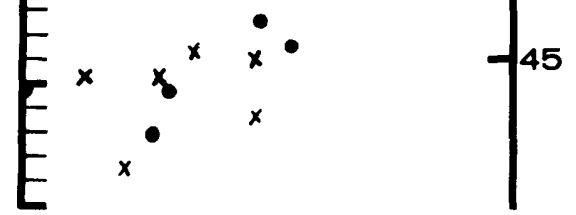


high organic-carbon contents (some values in excess of 2 percent). The kerogens in this interval are predominantly gas-prone, hydrogenpoor, exinite and vitrinite types. "Below $14,900 \mathrm{ft}(4,542 \mathrm{~m})$ the $\mathrm{C}_{15}+11$ quid-hydrocarbongas chromatograms show a systematic decrease in the magnitude of the unresolved envelope and a relative increase in the concentration of the lower molecular welght, resolved, saturated paraffin-napthenes" (Miller and others, this volume). These factors, coupled with a significant increase in the concentration of $\mathrm{C}_{1}$ to $\mathrm{C}_{4}$ light hydrocarbons, increased gas-wetness values, and TAI values and vitrinite-reflectance percentages as high as 2.2 and 0.54 , respectively, at the base of the we11, all indicate that incipient thermal maturity is likely to have been reached in the basal section in this well. Indeed, the vitrinite-reflectance data reported by Core Laboratories (1979) for this well represent minimum values (based on cuttings). Vitrinite-reflectance studies of an in-situ coal from $15,570 \mathrm{ft}(4,746 \mathrm{~m})$ yielded $\mathrm{R}_{\mathrm{o}}$ values of between 0.83 and 1.13 percent, values well within the range normally interpreted as indicating thermal maturity. The interval from about $15,000 \mathrm{ft}(4,572 \mathrm{~m})$ to $15,820 \mathrm{ft}(4,822 \mathrm{~m})$ is therefore considered to be an excellent potential gas source which is at or very near thermal maturity. The discovery of a "significant" gas show in the interval from 15,744 to 15,752 ft $(4,799$ to $4,801 \mathrm{~m})$ during the drilling of the $B-3$ well serves to confirm this evaluation.

The presence of a thick column of sedimentary strata below the total depth of the B-3 well, coupled with the low geothermal gradient in the area and the marginal thermal maturity, indicates the possiblity of a thick section of rocks with petroleum-source possibilities below $16,000 \mathrm{ft}(4,875 \mathrm{~m})$ in this region.

Essentially, five major factors are involved in the origin and entrapment of hydrocarbons: (1) source rocks, (2) temperatures sufficlent to generate liquid or gaseous hydrocarbons, (3) porous reservoir rocks, (4) Impermeable seals, and (5) structural and (or) stratigraphic traps. Indications from the B-3 well are that rocks of high organlccarbon content are present in the uppermost and lowermost parts of the total section penetrated. The upper interval is ofl-prone; the lower is gas-prone. Rocks between these sections have lower organic-carbon contents and lower oll- or gas-generation potentials.

Temperatures appear to have been sufficient for possible hydrocarbon generation in the deeper, gas-prone Interval, below $15,000 \mathrm{ft}$

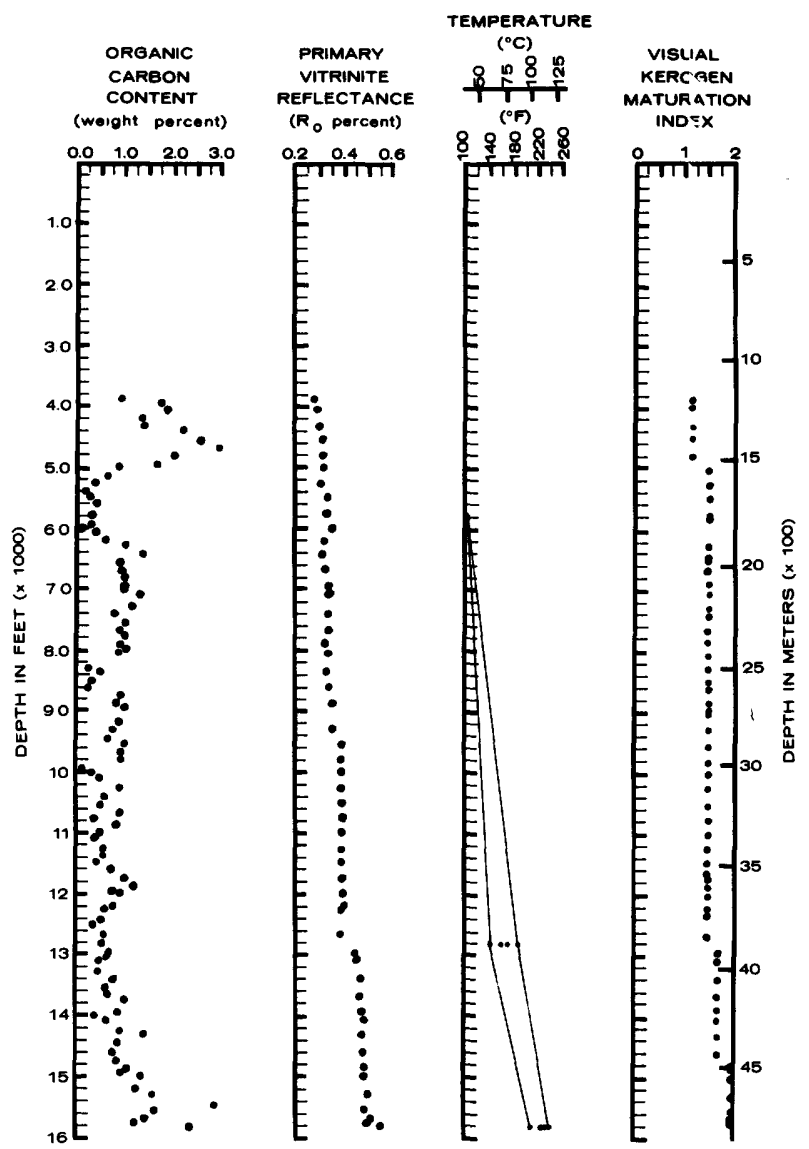

Figure 9.--Comparison of various geochemical and thermal parameters as a function of depth in the $\operatorname{cosT}$ No. B-3 well. Organic carbon content, primary vitrinite reflectance, and visual kerogen maturation data are $\mathrm{frcm}$ Core Laboratories (1979); we]1-bore temperature values are from Ams to and Simonis (1979).

$(4,572 \mathrm{~m})$. The shallower, oil-prone interval is thermally immature and is not likely to have acted as a source rock.

Potential reservolr rocks, particularly for gas deposits, are distributed throughout the lower half of the section in the B-3 well. These rocks, sandstones and possibly also some limestones, have high porosities and moderate to low permeabilities. Reservoir units are present both within and immediately above the interval of maximum gas-generation potential (below $15,000 \mathrm{ft} ; 4,572 \mathrm{~m})$. Presumably, sandstone

Figure 8.--Porosities and permeabilities measured using conventional and sidewall cores from the COST No. B-3 well as a function of depth (data from Amato and Simonis, 1979). When numerous core measurements were available for short depth intervals, plotted values are averages and are shown by an X symbol. All other (nonaverage) values shown as dots. 
Table 1.--Comparison of blostratigraphic analyses from the COST No. B-3 well

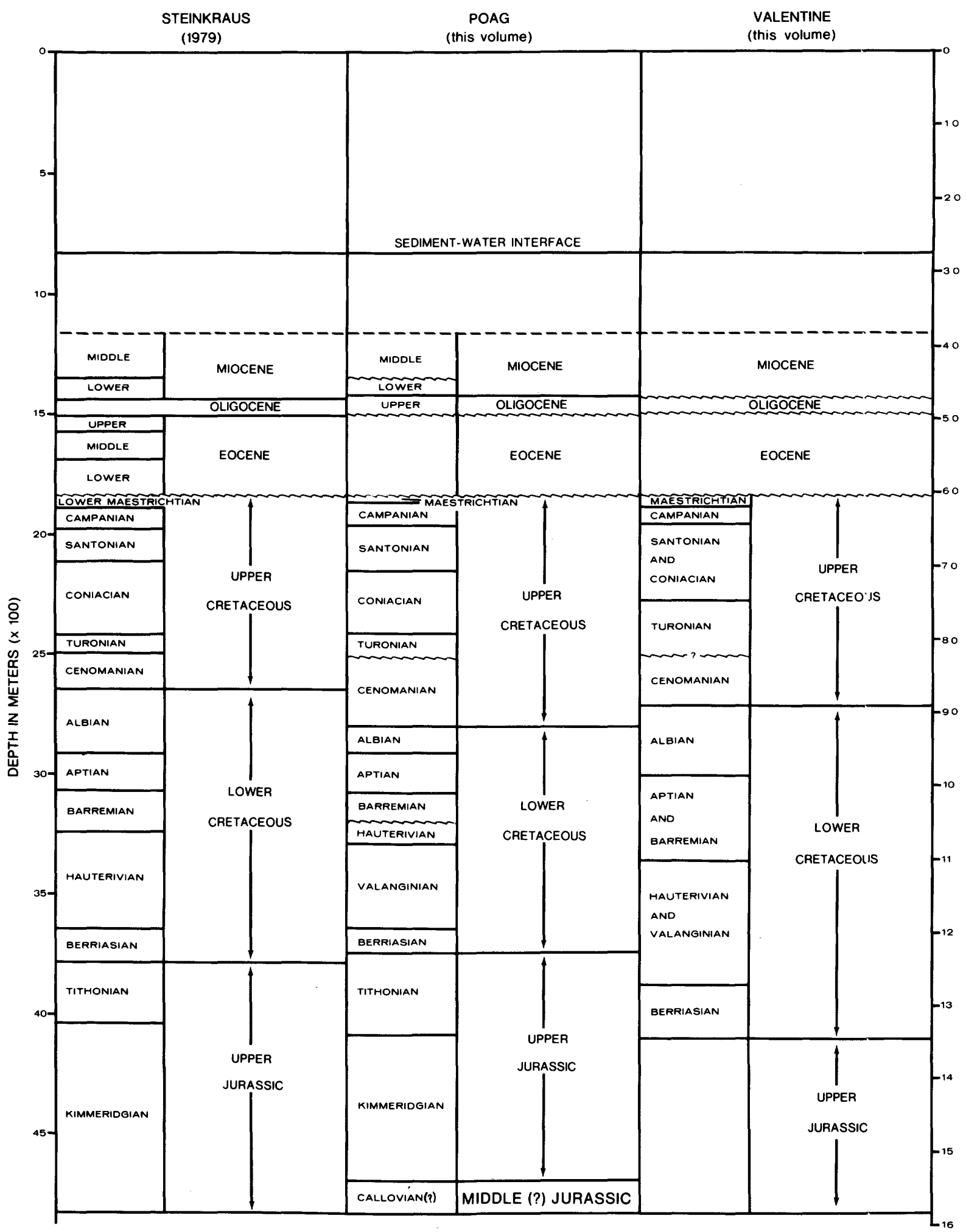


reservoir rocks with adequate porosity and permeability are also present below the depths penetrated by the $\mathrm{B}-3$ well.

Seals, in the form of shales, are present throughout the $\mathrm{B}-3$ section. In addition, impermeable limestone beds, which may act as seals, are also present in the deepest parts of the well.

Although the avallability of structures for hydrocarbon trapping cannot be evaluated from a single well intentionally drilled off-structure, regional geophysical studies indicate the presence of structures associated with JurassicCretaceous shelf-margin carbonate buildups as well as block faulting in the area of the B-3 we11. Furthermore, the rapid facies changes of sandstones, shales, and limestones in the lower parts of the COST Nos. B-2 and B-3 wells, combined with the expected facies changes between the $\mathrm{B}-3$ well and the Jurassic-Cretaceous bank-margin carbonate buildup, indicate that the potential for significant stratigraphic traps is high in this area.

In tota1, then, the potential for economic gas accumulations in this area is tigh; the potential for ofl accumulations is significantly lower, however. 


\section{LITHOLOGY}

Barry M. Pollack

Drill cuttings from the COST No. B-3 well were obtained and microscopically examined at 30-ft (9.14-m) intervals between 3,810 and 5,790 ft $(1,160$ and $1,765 \mathrm{~m})$ and at $10-\mathrm{ft}(3.05-\mathrm{m})$ intervals between 5,790 and $15,820 \mathrm{ft}(1,760$ and $4,822 \mathrm{~m}$ ) total depth (TD). References to the types of microfossils present are from Steinkraus (1979).

Lachance (1979) has divided the stratigraphic sequence penetrated by the COST No. B-3 well into four major 1ithologic units. The major divisions of Lachance have been followed with only minor differences in reported depths. These minor variations probably reflect a difference in sample interval and the fact that the contacts between most of the units are gradational. The stratigraphic sequence penetrated by the COST No. B-3 well is shown in a columnar section in figure 10. Unit $I$, between 3,810 and $6,150 \mathrm{ft}(1,160$ and $1,870 \mathrm{~m})$, is of Tertiary age and consists primarily of calcareous clay with minor amounts of sand and limestone. Unit II, between 6,150 and $8,250 \mathrm{ft}$ $(1,870$ and $2,510 \mathrm{~m})$, is of Late Cretaceous age and consists primarily of mudstone and siltstone with some glauconitic sandstone and dolomitic limestone. Unit III, between 8,250 and 12,300 ft $(2,510$ and $3,750 \mathrm{~m})$, is of Early to Late Cretaceous age and consists primarily of sandstone and shale with some minor amounts of carbonate. Unit IV, between 12,300 and 15,820 ft $(3,750$ and $4,822 \mathrm{~m})$, is chiefly of Late Jurassic age and consists primarily of shales.

UNIT I $(3,810-6,150 \mathrm{ft} ; 1,160-1,870 \mathrm{~m})$

This unit is divided into subunits IA and IB on the basis of abundant layers of limestone below a depth of about $5,100 \mathrm{ft}(1,550 \mathrm{~m})$.

Subuntt IA $(3,810-5,100 \mathrm{ft} ; 1,160-1,550 \mathrm{~m})$ consists primarily of dark-gray to white, calcareous clay. It contains minor amounts of quartz sand and shell fragments. The sand is fine to medium grained, is relatively clean, and has angular to rounded grains. The shell fragments and microfossils are primarily Foraminifera; there are, however, some palynomorphs and nannofossils. Glauconite is present as rounded individual grains and in botryoidal aggregates in amounts $r$ anging from traces to locally abundant in the sandier portions of the subunit. Gypsum is present in sparse to locally abundant amounts in the form of authigenic, thin to thick, tabular crystals, which are sometimes aggregated in a micritic matrix. Mica is present in varying amounts throughout the subunit. Other trane constituents Include pyrite in subhedral to euhedral crystals, argillaceous limestone, and ooliths wth quartz nucleil.

Subunit IB $(5,100-6,150 \mathrm{ft} ; 1,550-1,870 \mathrm{~m})$ consists of light-gray to white claystone, which is locally very calcareous, and har some thin layers of white microcrystalline, fossiliferous limestone. Similar micritic calcite appears to be present in the calcareous claystone. Glauconite ranges from trace amounts in the claystone and limestone to locally abundant in sand lenses. The glaucontte is usially in the form of botryoldal masses but has a few individual rounded grains. The sand a are clean, fine to medium grained, and angular to well rounded; they contain clear to frcsted quartz grains. Other trace constituerts include massive and euhedral pyrite; gypsum in thin and thick tabular crystals; buff-colored, dense, blocky dolomite; and satin spar gypsum. Microfossils Include Foraminifera, nannofossils, and palynomorphs.

$$
\text { UNIT II }(6,150-8,250 \mathrm{ft} ; 1,870-2,510 \mathrm{~m})
$$

This unit consists primarily of purple to gray and brown, locally very calcarecis mudstone interbedded with glauconitic sandstone and dolomitic limestone. This lithology grades downward into a dark-gray calcareous claystone at about $7,810 \mathrm{ft}(2,380 \mathrm{~m})$. The sandstone is composed of fine to coarse, angular to subrounded, clear to gray, opaque quartz sand

Figure 10.--Generalized plot of lithologies based on examinations of cuttings from the CosT No. B3 we11. The biostratigraphic relationships are based on Steinkraus (197^) and work conducted by International Biostratigraphers, Inc. (written communication, 1979). 


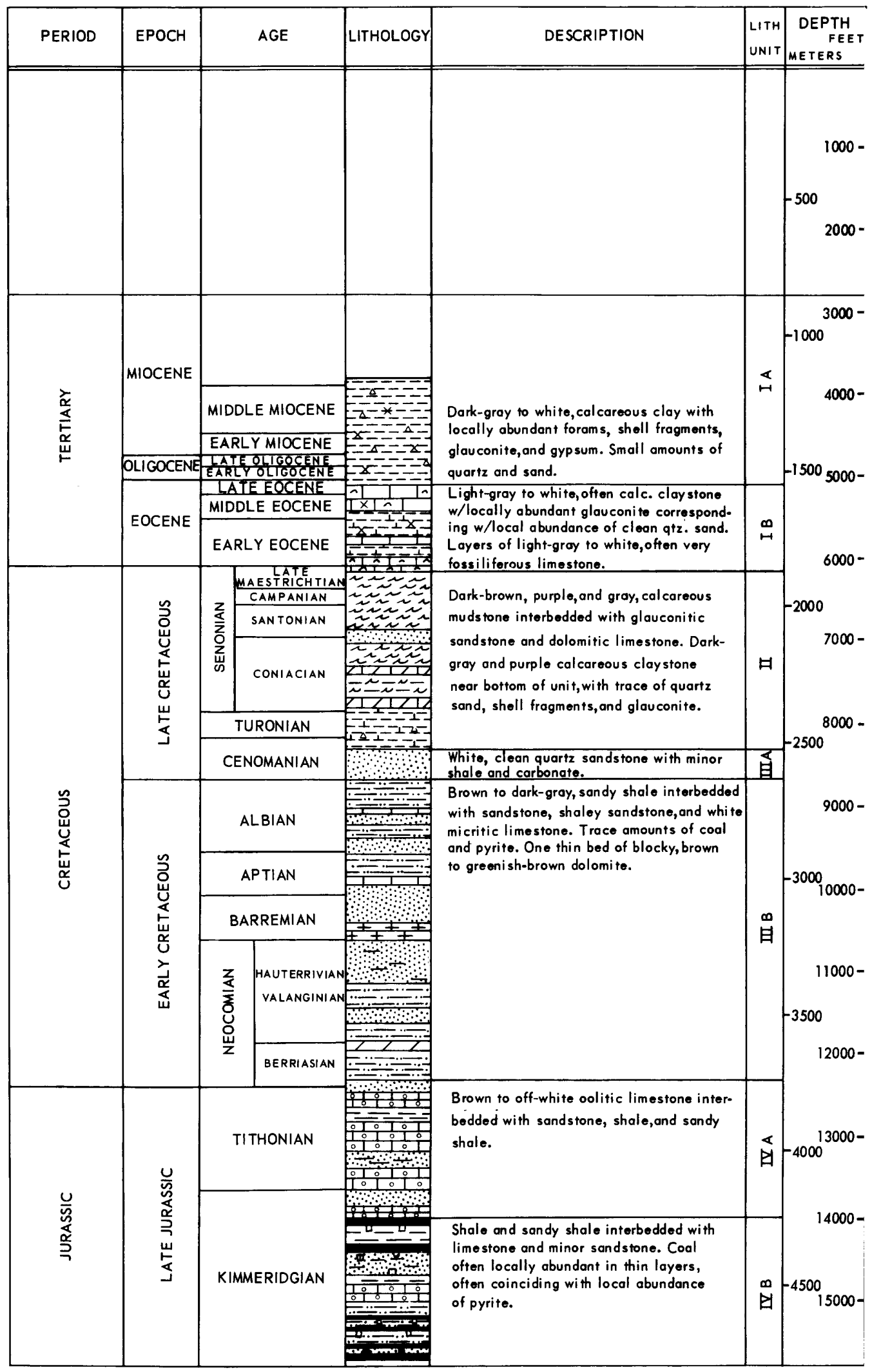


grains. The glauconite is present in trace amounts in the mudstone, is abundant in the sanstone, and is primarily in the form of botryoldal aggregates. The limestone occurs in very thin layers and is a gray to buff-colored micrite with small amounts of hard, dense, blocky, brown dolomite. Other trace constituents include massive nodular and euhedral pyrite and microfossils. The microfossils Include Foraminifera, palynomorphs, and nannofossils.

The claystone, $7,810-8,250$ ft $(2,380-2,510$ $m$ ), contains traces of clear quartz which is fine to medium grained, angular to well rounded, and, in a few cases, in the form of polycrystalline aggregates. Other trace constituents include nodular, massive, and euhedral pyrite and botryoidal aggregates of glauconite. Mica is present in trace amounts throughout the unit.

\section{UNIT III $(8,250-12,300 \mathrm{ft} ; 2,510-3,750 \mathrm{~m})$}

This unit can be divided into subunits IIIA and IIIB on the basis of the greater amount of clean quartz sandstone above $9,000 \mathrm{ft}(2,740 \mathrm{~m})$.

The upper subunit, IIIA $(8,250-9,000 \mathrm{ft}$; $2,510-2,740 \mathrm{~m})$, contains clean quartz sandstone, interbedded shale, and minor amounts of limestone. The sandstone is light gray to white, is noncalcareous to slightly calcareous, and has clay and (or) silica cement predominating. It is moderately sorted, well consolidated, and very fine to medium grained; the grains are angular to subrounded and clear to gray-opaque (locally with frosted grains). Glauconite ranges from trace to sparse amounts, usually in the form of botryoldal masses with a few individual grains. The glauconite $1 \mathrm{~s}$ more abundant in the sandstone than in any other parts of the subunit. Other trace constituents include pyrite in euhedral crystals and nodular masses, mica (disseminated throughout the subun(t), and marine microfossils. The shale is primarily medium to light gray, noncalcareous to moderately calcareous (micrite), with small amounts of coal. Pyrite, usually in massive form with some euhedral crystals, is present in trace amounts and is slightly more abundant in coal-bearing strata.

The carbonate material is primarily in the form of white to off-white laminae in the shale. It is nonfossiliferous to slightly fossiliferous, soft, dense, and micritic, and contalns trace amounts of clean sand which is fine-grained and angular to rounded. Microfossils in this subunit include Foraminifera, palynomorphs, and nannofossils.

Subunit IIIB $(9,000-12,300 \mathrm{ft} ; 2,740-3,750$ m) is predominantly sandy shale interbedded with sandstone, shaley sandstone, and limestone. Near the top and bottom of this subunit, the ratio of sandstone to shale shows a significant increase. Apparently on the basis of this change in the sandstone/shale ratio, Lachance
(1979) subdivided the interval from 9,000 to 12,300 ft $(2,740-3,750 \mathrm{~m})$.

The shale in subunit IIIB is brown to dark gray to locally black and chlefly norcalcareous, but some samples contain large amounts of sand. The sand, mostly in the form of fine- to medium-grained quartz, is clear to frosted and angular to subrounded. Other trace ronstituents include massive pyrite associated with coal; glauconite in botryoldal masses (more abundant in the sandier portions of the shale); hard, dense, brown, blocky dolomite, crystalline calcite; and microfossils. The sandstone is light gray to brownish gray to buff colored, slightly to moderately calcareous, and poorly to moderately sorted; it contains angular to subangular, clear to gray and brown opaque grains. It 18 generally fine to moderately coarse grained. Trace constituents include botryoldal masses of glaucontte, nodular pyrite, and microfossils.

The two thick sandstone beds ir the middle of this subunit (at $10,000 \mathrm{ft}$ and $10,600 \mathrm{ft}$; 3,050 and $3,230 \mathrm{~m}$ ) are fairly clean, white, very fine to fine grained, with calcarenus cement. The grains are subrounded to rounded and clear to frosted. Trace constituents include glauconite in botryoldal masses (wlich is more abundant here than in other parts of the subunit), coal, and microfossils.

Microfossils in this subunit include palynomorphs, nannofossils, and Foraminifera to a depth of about $9,530 \mathrm{ft}(2,900)$.

\section{UNIT IV $(12,300-15,820 \mathrm{ft} ; 3,750-4,822 \mathrm{~m}$ [TD] )}

This unit is divided into two sibunits (IVA and $I V B$ ) on the basis of a predominance of sandstone and limestone above $14,000 \mathrm{ft}(4,270 \mathrm{~m})$.

The upper subunit (IVA 12,300-14,000 ft; $3,750-4,270 \mathrm{~m}$ ) consists primarily of interbedded sandstone, shale, sandy shale, and oolitic limestone. The sandstone is generally white to light gray, well consolidated, fine to moderately coarse grained, poorly tc moderately sorted, with angular to subrounded grains. Trace constituents include glauconite, pyrite, and coal. The glaucontte $1 \mathrm{~s}$ more al indant here than in other parts of the sut rnit. It generally occurs as botryoidal aggregates, although there are a few individual subrounded grains. The pyrite occurs as massive nodules concentrated around pieces of coal.

The shale is light to dark grey, commonly sandy, and moderately calcareous. Micrite, which is present in varying amounts, gives the shale its calcareous nature. It s sand is primarily clean, fine to moderately coarse grained, clear to opaque, with angular to subrounded grains. Trace constituents include glauconite, pyrite, and coal. The glauconite occurs as botryoldal aggregates in th sand.

The carbonate is brownish gray to off white and ranges from a soft micrite to a 1 ard, dense, somewhat argillaceous, finely crystalline 
1imestone. Ooliths range from sparse to very abundant; they are most abundant in the micrite where they make up a significant percentage of the rock. The micrite acts as matrix around the ooliths which have quartz nucle11. Trace constituents include botryoidal aggregates of glauconite, massive-nodular pyrite, and coal. Microfossils in this subunit include palynomorphs to a depth of $13,220 \mathrm{ft}(4,050 \mathrm{~m})$; palynomorphs and nannofossils from 13,220 to $13,960 \mathrm{ft}(4,050$ to $4,250 \mathrm{~m})$; and palynomorphs, nannofossils, and Foraminifera from 13,960 to 14,000 ft $(4,250$ to $4,270 \mathrm{~m})$.

The lower subunit (IVB, 14,000-15,820 ft; $4,270-4,822 \mathrm{~m}$, [TD]) consists of sandy shale interbedded with limestone and minor amounts of sandstone. The shale ls light to dark gray (locally black near the bottom of the well), ranges from somewhat calcareous to very calcareous, and is locally very sandy. Micrite, in places acting as matrix, gives the shale a calcareous nature. The sandstone is primarily a clean quartz sand, fine to medium grained, clear to frosted, angular to moderately well rounded. Trace constituents include glauconite in botryoldal aggregates (more abundant in the sandier parts of the section), nodular-massive pyrite, coal, and microfossils. The pyrite is closely associated with the coal. The limestone ranges from soft and micritic to hard, dense, and finely crystalline. It is generally light gray to white and slightly argillaceous. Ooliths with quartz nucleil range from trace amounts in the crystalline Iimestone to 1ocally abundant in the micritic limestone, where the micrite acts as matrix. Trace constituents include nodular-massive pyrite and microfossils. The sandstone ranges from predominantly white to light gray and buff colored. It is slightly calcareous to very calcareous and is locally consolidated with micritic matrix and (or) carbonate cement. Although the sandstone is usually well consolidated, a zone of poorly consolidated sandstone occurs between 15,750 and $15,780 \mathrm{ft}(4,800 \mathrm{~m}$ and $4,810 \mathrm{~m})$, the reported gas zone. In the gas zone, the sandstone is clean, white, and moderately sorted. Coal varies from trace to locally abundant, and the more abundant coal zones are usually associated with a noticeable increase in the abundance of pyrite. Other trace constituents include glauconite in the form of botryoidal masses; hard, dense, blocky, brown, cryptocrystalline dolomite; and microfossils. There is a notable lack of glauconite in the gas-bearing sand zone $(15,750$ to $15,780 \mathrm{ft} ; 4,800$ to $4,810 \mathrm{~m})$. 


\title{
SANDSTONE PETROGRAPHY
}

\author{
Barry M. Pollack
}

Rotary drill cuttings of sandstone were chosen at 27 levels from $8,300 \mathrm{ft}(2,530 \mathrm{~m})$ to $15,780 \mathrm{ft}(4,810 \mathrm{~m})$ for petrographic analys1s. Thin sections were made of samples from each interval and stained to show potassium feldspar. The thin sections were examined by means of a standard petrographic microscope; the results of this analysis are shown in table 2 .

During drilling, coarse sand and gravel tend to disaggregate into Individual constituent grains, making examination of representative rock textures Impossible. Therefore, the grainsize columns of the table merely indicate the coarseness of the material examined and do not necessarily reflect the average grain size of sand in that interval. Thus, the finer grained and more lithified units in the section are emphasized in this analysis. Nevertheless, the overall changes in rock composition, fabric, and diagenesis described in the selected samples are probably representative of the whole section.

\section{COMPOSITION}

The entire section from $8,300 \mathrm{ft}(2,530 \mathrm{~m})$ to $15,780 \mathrm{ft}(4,810 \mathrm{~m})$ is quartzofeldspathic, and most sandstone 13 classed as quartz arenite. Part of the sandstone (about one third) is sufficiently feldspathic to be classed as subarkose. Although there is a marked decrease in the ratio of potassium feldspar (orthoclase and microcline) to plagioclase feldspar below $11,100 \mathrm{ft}(3,383 \mathrm{~m})$, plagloclase is subordinate to the other feldspars throughout the section. The decrease in the amount of potassium feldspar below $11,100 \mathrm{ft}(3,383 \mathrm{~m})$ probably reflects changes in provenance, as the potassium feldspar is not observed to be drastically altered.

Rock fragments are present throughout the section, although they never constitute a major rock-forming element. The rock fragments noted were primarily of sedimentary origin (shale, 1imestone, and sedimentary quartzite).

Most of the sediment in the section contains glaucontte (of both pelletal and vermicular form) in varying amounts. Below 15,740 ft $(4,798 \mathrm{~m})$, however, glauconite is notably lacking. The glaucontte, in confunction with calcareous microfossils and limestone,
Indicates dominantly marine desositional conditions.

The sandstones are slightly miciceous and somewhat pyritic throughout the $8,300-\mathrm{ft} \quad(2,530-$ m) to $15,740-f t(4,798-\mathrm{ta})$ section; in some intervals pyrite is quite abundant. Lignitic inclusions are commonly present, especially between 10,300 and $10,800 \mathrm{ft}(3,139$ and $3,292 \mathrm{~m})$ and between 15,760 and 15,780 ft $(4,804$ and $4,810 \mathrm{~m})$.

\section{DIAGENESIS AND CEMENTATION}

Malinowsk1 (1979) has shown thar the mean porosity of the sediments in the COST No. B-3 well decreases slightly with depth. This is to be expected in mineralogically imnature sediments because of sediment compaction resulting from an increase of overburden pressure as a function of depth, as well as from progressive cementation. However, in the depth intervals examined, there are no ohservable, significant compaction effects such as crushing of relatively soft grains (glauconite and mica), orientation of elongate grains, and shattering or twinning of brittle minerals. Grain interpenetration through pressure solution was observed in a few places in the section. This is seen primarily in polycrystalline quartz grains with interlocking boundaries. The scarcity of these grains seems to indicate that the pressure-solution effects occurred prior to deposition in this particular section. There is little indication that mechanical compaction resulting from increased subsurface lithostatic pressure has played a major role in loss of porosity in these sediments.

The chemical effects of mineral alteration and cement prectpitation, although not large in scale, are more important in porosity reduction than are compaction effects. Starting at about $11,000 \mathrm{ft}(3,353 \mathrm{~m})$, alteration of potassium feldspar and plagloclase feldspar (a] though of relatively small extent) becomes more important with increasing burlal depth. This alteration takes the form of sericitization, kaolinization, or calcite replacement; it varies in form and intensity from one unit to the next. Although the Increase in feldspar alteration may be correlatable with a slight increase in 


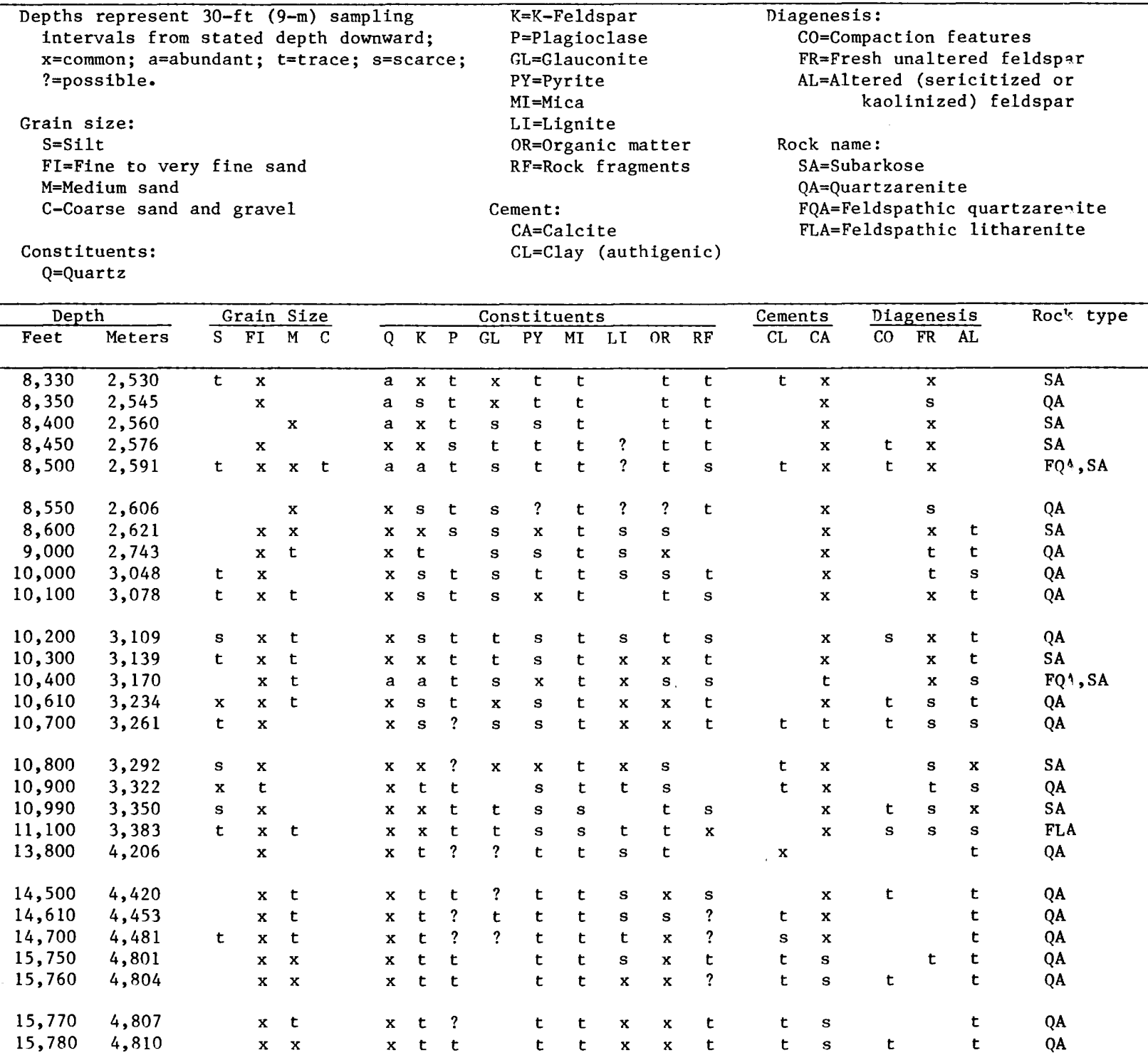

authigenic clay minerals as cementing agents, the general trend appears to be one of consistent calcite cementation with occasional occurrences of clay matrix. Calcite is clearly the most important cement throughout the section. Below 13,800 ft $(4,206 \mathrm{~m})$ the amount of authigenic clay Increases, but calcite cementation still predominates. In the more fossiliferous units, the calcite cenent displays polkilitic textures. This seem to Indicate that, at least in these units, the presence of skeletal grains or carbonate rock fragments played a significant role in the nucleation of calcite cement. In the reported $\mathbf{g a s}$ zone from 15,750 to 15,780 ft $(4,801$ to $4,810 \mathrm{~m})$, there $1 \mathrm{~s}$ a noticeable decrease in the cementation of the sandstone. What cement is present in that interval, however, is primarily calcite.

\section{CONCLUSIONS}

The loss of porosity with desth (as described by Malinowsk1, 1979) 1s largely the result of calcite cementation rather than of compaction or feldspar alteration. The prospects for Improved porosity at equivalent or greater depths at other sites are relatively unfavorable unless some factor has significantly retarded or halted the in-situ production of calcite cement. Even if this cementation does not occur at other sites, compaction or alteration effects might be more significant in such areas. 
COMPUTER WELL-LOG ANALYSIS

Ching H. Wu and Renny R. Nichols

Well logs from the COST No. B-3 well were analyzed using a computer program--LOGCALC ${ }^{1}$. The well logs were recorded on a Schlumberger LIS tape as well as on analog papers. Only the following logs were used in the computer analys1s: Dual-induction sphertcally-focused 108 (DISFL), Long-spaced sonic $\log$ (LSS), Compensated neutron formation density $\log$ (CNL/FDC), and Compensated formation density $\log$ (FDC).

Briefly, the computer well-log analysis was performed as follows:

1. Selected Intervals for $\log$ analysis on the basis of lithology and depositional environments.

2. Determined the formation-water resistivity of each interval using recorded spontaneous potentials.

3. Determined $10 g$ parameters for LOGCALC analysis; executed LOGCALC programs to obtain preliminary results.

4. Analyzed LOGCALC outputs and determined 108 parameters from crossplots.

5. Used LOGCALC to process intervals when core data were available.

6. Compared core and computed porosity data; then made necessary corrections on FDC.

7. Made LOGCALC runs to obtain the final loganalysis results.

Only two large intervals were selected for computer we11-log analysis because of time and cost constraints. The first interval ranges from 8,200 to 12,400 ft $(2,499$ to $3,779 \mathrm{~m})$, corresponding to the Lower Cretaceous deltaic sand-shale sequences. The second interval ranges from 12,400 to 15,810 ft $(3,779$ to 4,818 $\mathrm{m})$, corresponding to the Upper Jurassic carbonate and interbedded sandstone sequences deposited in marine to nonmarine environments. Because a different set of 1ithologic and $10 g$ parameters was used for each of the two large intervals, computer-analysis results should be considered as qualitative. Extreme caution is advised and other reference materlals should be considered when using the log-analysis results.

Two we11-log-analysis models were used in the $\log$ analysis. Because the formations from 8,200 to $12,400 \mathrm{ft}(2,499$ to $3,779 \mathrm{~m})$ are mainly sand-shale sequences, the interval was analyzed using a sand-shale log-analysis mode1 (SAM7). On the other hand, as the formations from 12,400 to 15,810 ft $(3,779$ to $4,818 \mathrm{~m})$ are mainly composed of carbonate rocks interbedded with sandstones, the interval was analyzed using both a sand-shale (SAM7) and complex 1ithology (CAM7) mode1.

The interval from 8,200 to $15,810 \mathrm{ft}(2,499$ to $4,818 \mathrm{~m}$ ) was logged in two separate runs. The bit sizes, mud weights, and assumed rock matrices were different below and above 12,688 ft $(3,867 \mathrm{~m})$. In addition, the lithology changed from a sand-shale sequenne to a carbonate-dominated sequence below $12,400 \mathrm{ft}$ $(3,779 \mathrm{~m})$. Therefore, the entire interval was divided into three sections for compiter welllog analysis. The input data and log-analysis models are shown in table 3.

Three computer runs (passes) were made for each section using a log-analysis model (SAM7 and (or) CAM7). Pass 11 prints out raw data and histograms of $\log$ responses that provide the range of each log variable and infornation for log-response calibrations. Pass 22 makes borehole corrections, mud corrections, response conversions, and cross-plot analyses. These factors provide some $10 \mathrm{~g}$ parameters, as 1isted in table 3, for pass-33 analysis. Pass 33 performs the we11-log analysis, whicl provides formation and lithology information.

Figures 11 through 14 show comparisons of we11-log-analysis and core-analysis data. Figure 11 shows a comparison of core (measured) and $\log$ (computed) porosities for the sandstone interval from 9,921 to $9,935 \mathrm{ft}(3,024$ to 3,028 m). The computed results were obtained after the density $10 \mathrm{~g}$ was multiplied by a correction factor of 0.99 based on the calibration infor-

\footnotetext{
${ }^{1}$ Purchased from the Scientific Software Corporation and installed in Honeywell Multics computer at Denver Federal Center, Denver, Colorado.
} 
Table 3.--Input iata for LOGCALC analysis

[(-) Indicates no data. For all intervals, constant a for Humble equation $=0.62$, constant $\mathrm{a}$ for Humble equation $=2.15$, compaction factor $=1 . n$, bottom-hole temperature $=238^{\circ} \mathrm{F}$, and approximate annual, mean sea-level temperature $=15.2^{\circ} \mathrm{F}$ ]

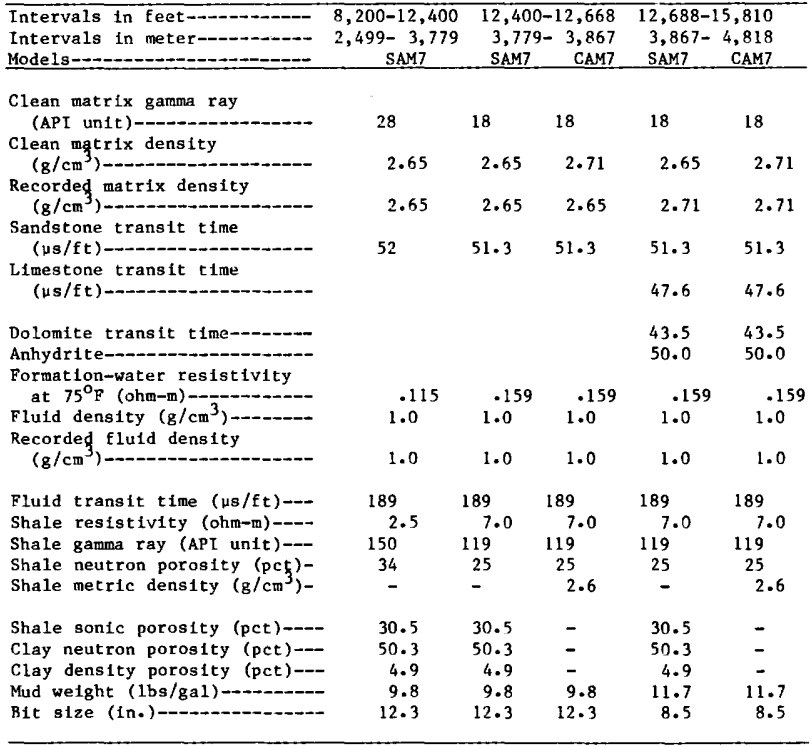

mation. The effective porosity is calculated by considering corrections due to shale content. As shown, the core and computer-calculated porosities are comparable. Figure 12 shows the comparison of core and computed ${ }^{2}$ porosities for the sandstone interval from 11,010 to $11,060 \mathrm{ft}$ $(3,356$ to $3,371 \mathrm{~m})$. Figure 13 shows that for the 11mestone section from 12,573 to $12,580 \mathrm{ft}$ $(3,832$ to $3,834 \mathrm{~m})$, CAM 7 provides porosity values comparable with those from core analysis. Although the density porosity is comparable with core porosity for the sandstone section from 12,583 to $12,587 \mathrm{ft}(3,835$ to 3,836 $m$ ), the effective porosity is set at zero owing to the high shale content. Figure 14 shows that in the sandstone section from 13,773 to 13,785 ft $(4,198$ to $4,201 \mathrm{~m})$, SAM7 calculated porosity values comparable to those measured in cores. However, below 13,785 ft $(4,201 \mathrm{~m})$, the borehole effect becomes significant, as seen on the caliper, so the porosity is set at zero. From the above comparisons, it is clear that computer we11-log analysis, when proper input is supplied, can provide qualitatively satisfactory porosity information.

Figures 15 and 16 show SAM7 analysis results for the section from 8,200 to $12,400 \mathrm{ft}$ $(2,499$ to $3,779 \mathrm{~m})$. Plots such as those shown on figures 15 and 16 yleld useful preliminary information for scanning through a large s:ratigraphic interval for correlation, fornation evaluation, and 11thology determination. Information from other sources and further, more detalled, well-log-analysis data should be used to verify the present log-analysis results.

Figures 17 and 18 show SAM7-analysis results for the interval from 12,400 to 15,810 ft $(3,779$ to $4,818 \mathrm{~m})$. Because significtant amounts of gas were detected by the mud-logging unt during drilling through the interval from 15,751 to $15,786 \mathrm{ft}(4,800$ to $4,810 \mathrm{~m})$, the $\log$ analysis results from the interval botween 15,700 and 15,810 ft $(4,785$ and 4,819 n) are enlarged and shown in figure 19. It appears that the gas show is most likely to have come from the intervals from 15,743 to $15,755 \mathrm{ft}$ $(4,798$ to $4,802 \mathrm{~m}$ ) and (or) from 15,767 to 15,775 ft $(4,806$ to $4,808 \mathrm{~m})$, both having an average porosity of 12 percent and an average water saturation of 29 percent. However, from further Investigation of the paper logs, it can be seen that an SP deflection occurs from 15,742 to $15,754 \mathrm{ft}(4,797$ to $4,801 \mathrm{~m})$ and that $a$ crossover of the FDC and the CNL exists from 15,745 to 15,753 ft $(4,798$ to 4,800 r), in confunction with the higher resistivity which clearly indicates a gas zone.

In order to provide more 11thnlogic information, the interval from 12,400 to 15,810 ft $(3,779$ to $4,818 \mathrm{~m})$ was also analyzed using CAM7. Results of CAM7 analysis are shown on figures 20 and 21. Track 5 shows the ccmputed quartz, calcite, and dolomite contents. Fecause of time limitations, lithological comparison with cuttings and core descriptions was nct made in this study.

In summary, computer well log-analysis can provide valuable preliminary information for correlation, formation evaluation, and lithology determination. Results of these computer welllog analyses must be verifled using information from other sources and from more detalled well$\log$ analysis on smaller subintervals.

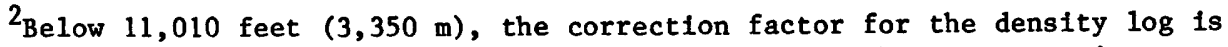

0.98 , which provides density porosity that matches the core porosity. 

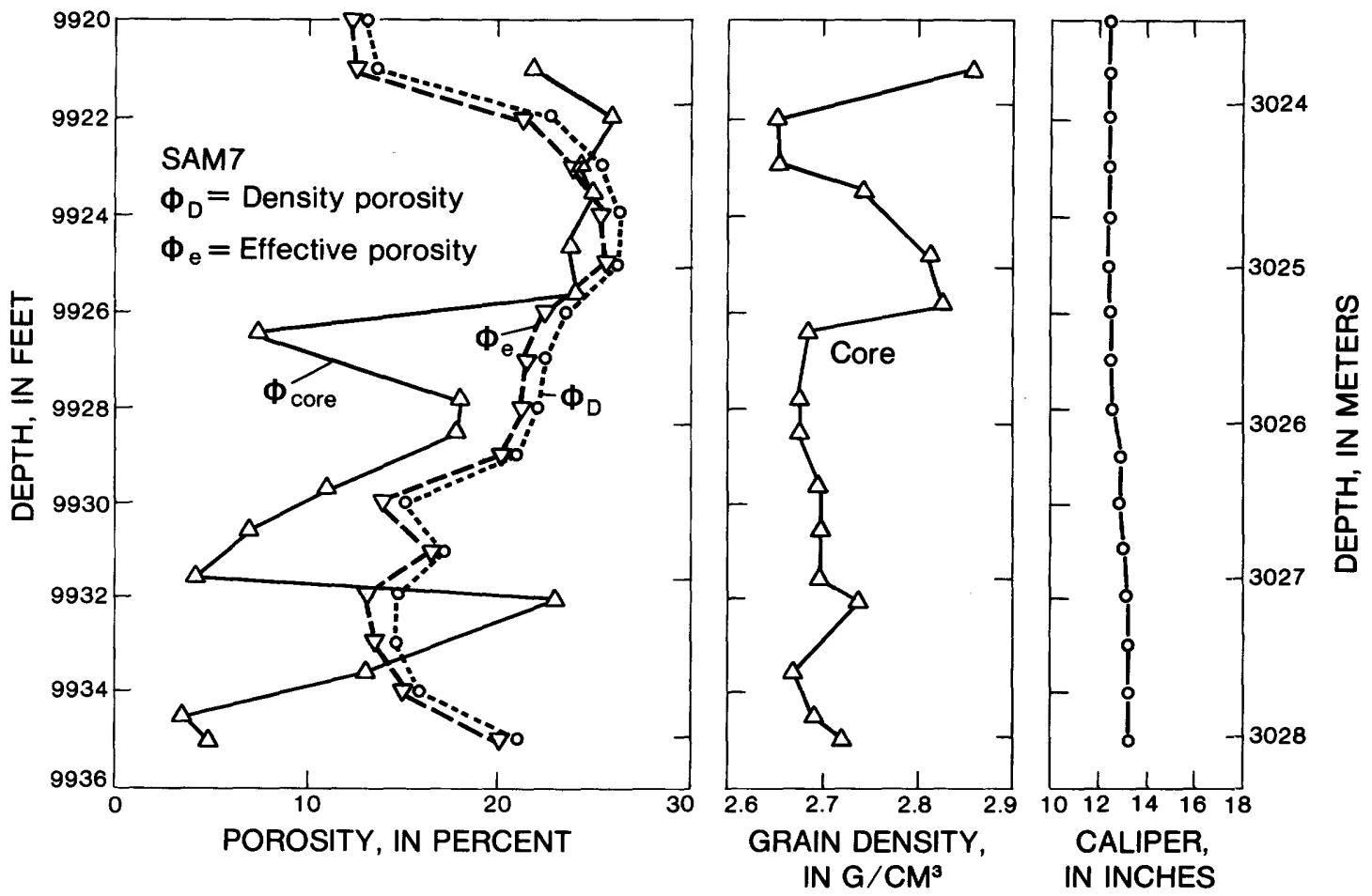

Figure 11.--Comparison of measured (core) and computed (log) porosities for the interval from 9,921 to $9,935 \mathrm{ft}(3,024$ to $3,028 \mathrm{~m})$.
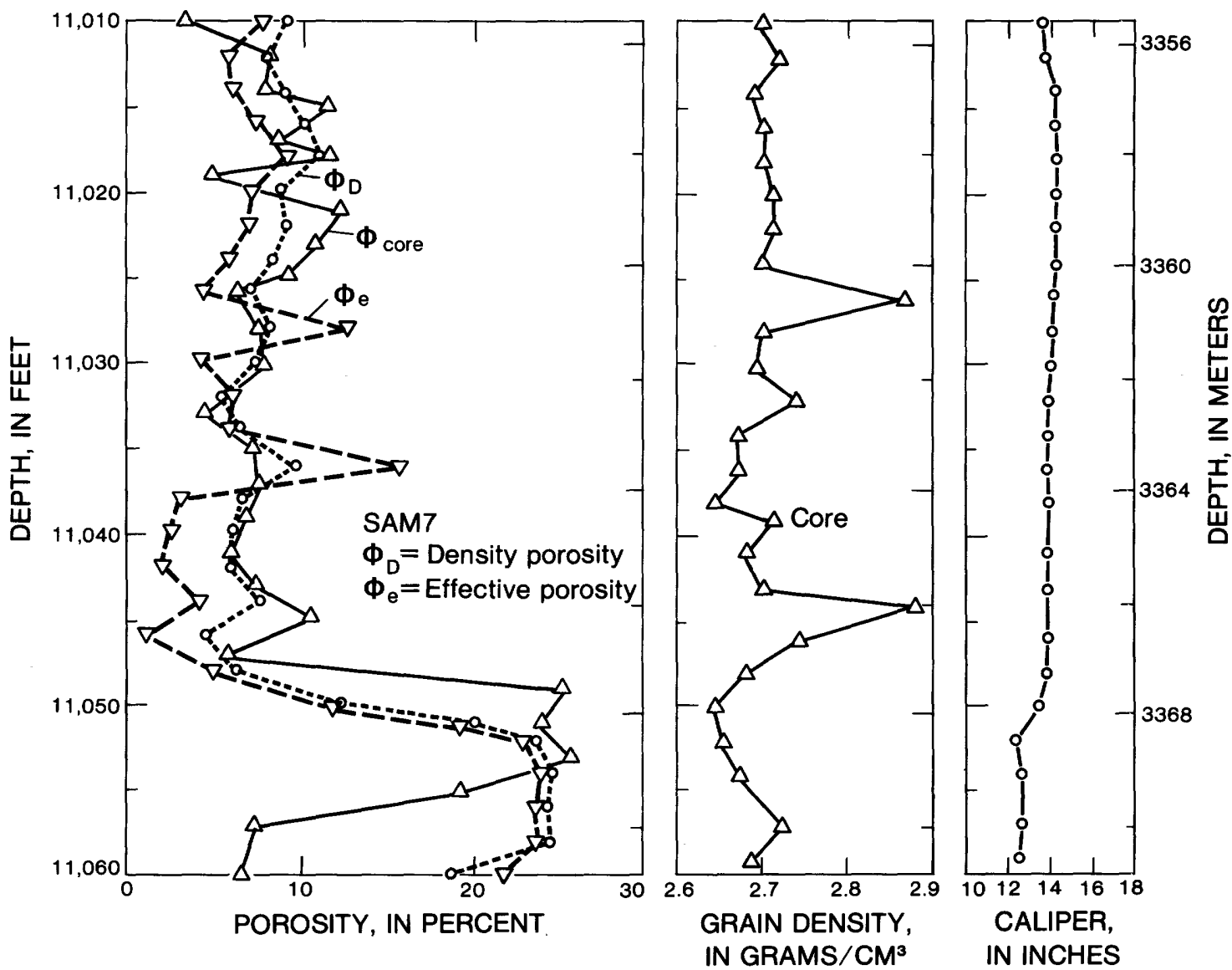

Figure 12.--Comparison of measured (core) and computed (log) porosity for the interval from 11,010 to $11,060 \mathrm{ft}(3,356$ to $3,371 \mathrm{~m})$. 

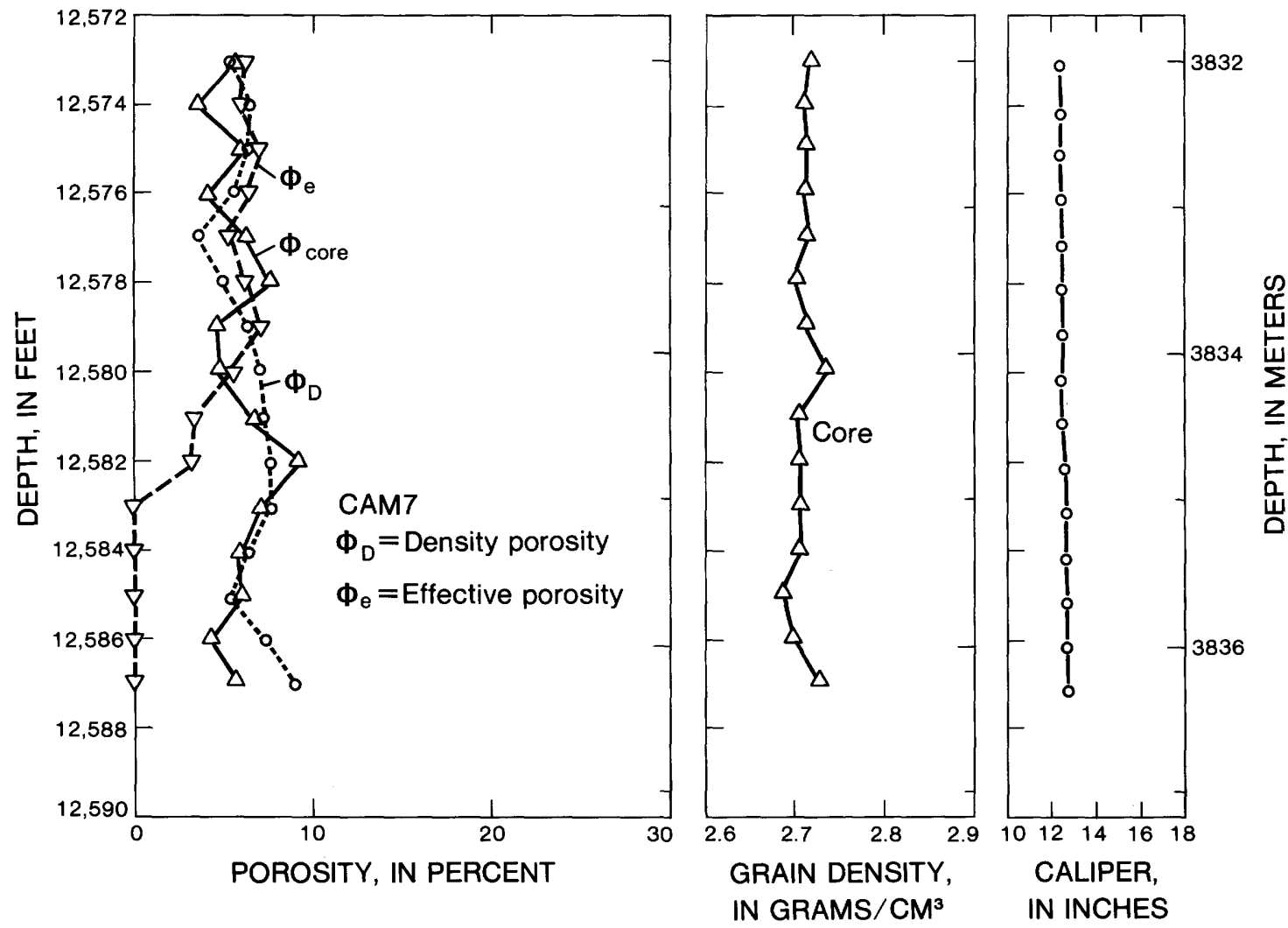

Figure 13.--Comparison of measured (core) and computed ( $\log$ ) porosity for the interval from 12,573 to $12,587 \mathrm{ft}(3,832$ to $3,836 \mathrm{~m})$.
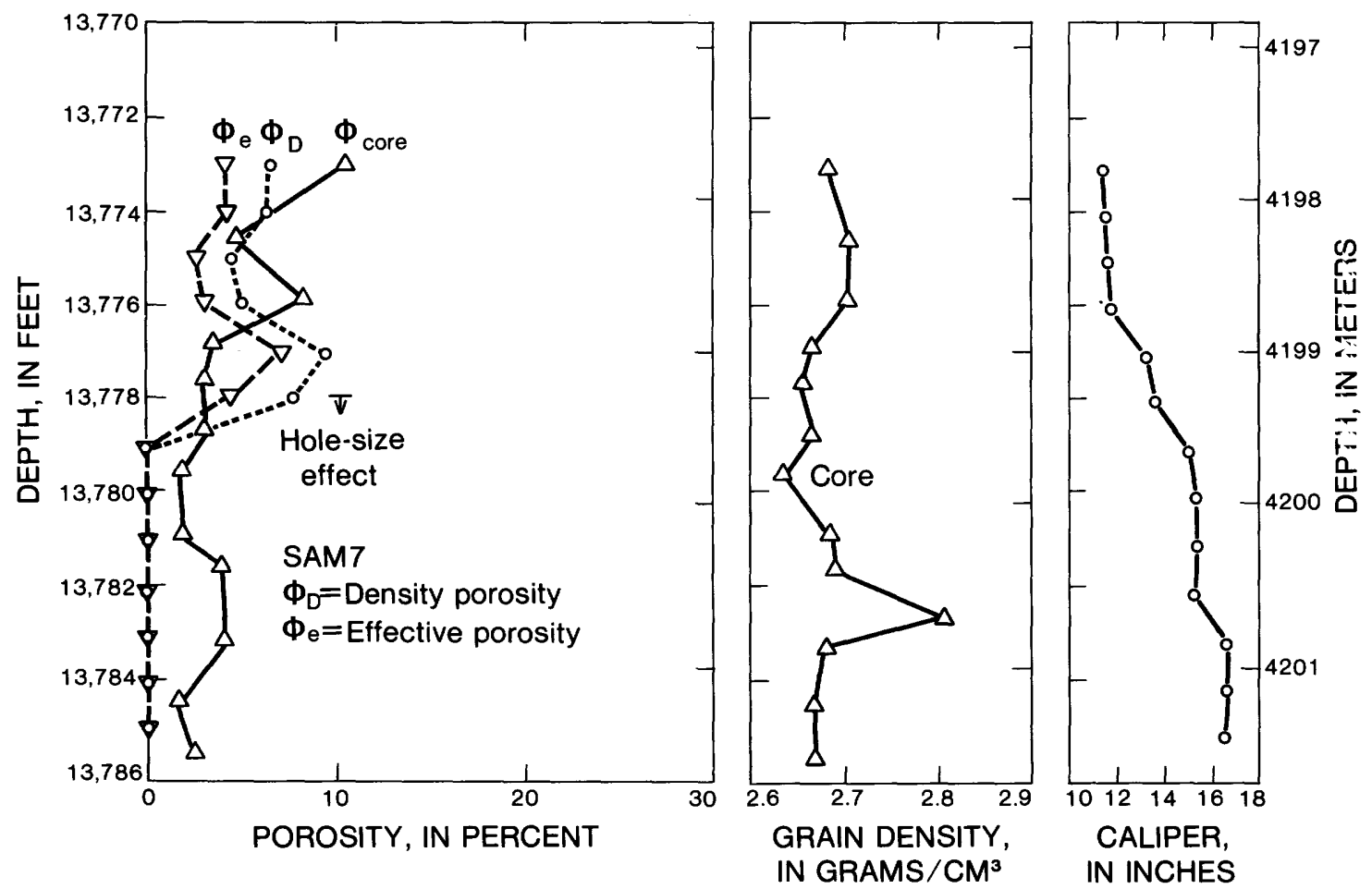

Figure 14.--Comparison of measured (core) and computed ( $10 \mathrm{~g}$ ) porosity for the interval from 13,773 to $13,786 \mathrm{ft}(4,198$ to $4,202 \mathrm{~m})$. 


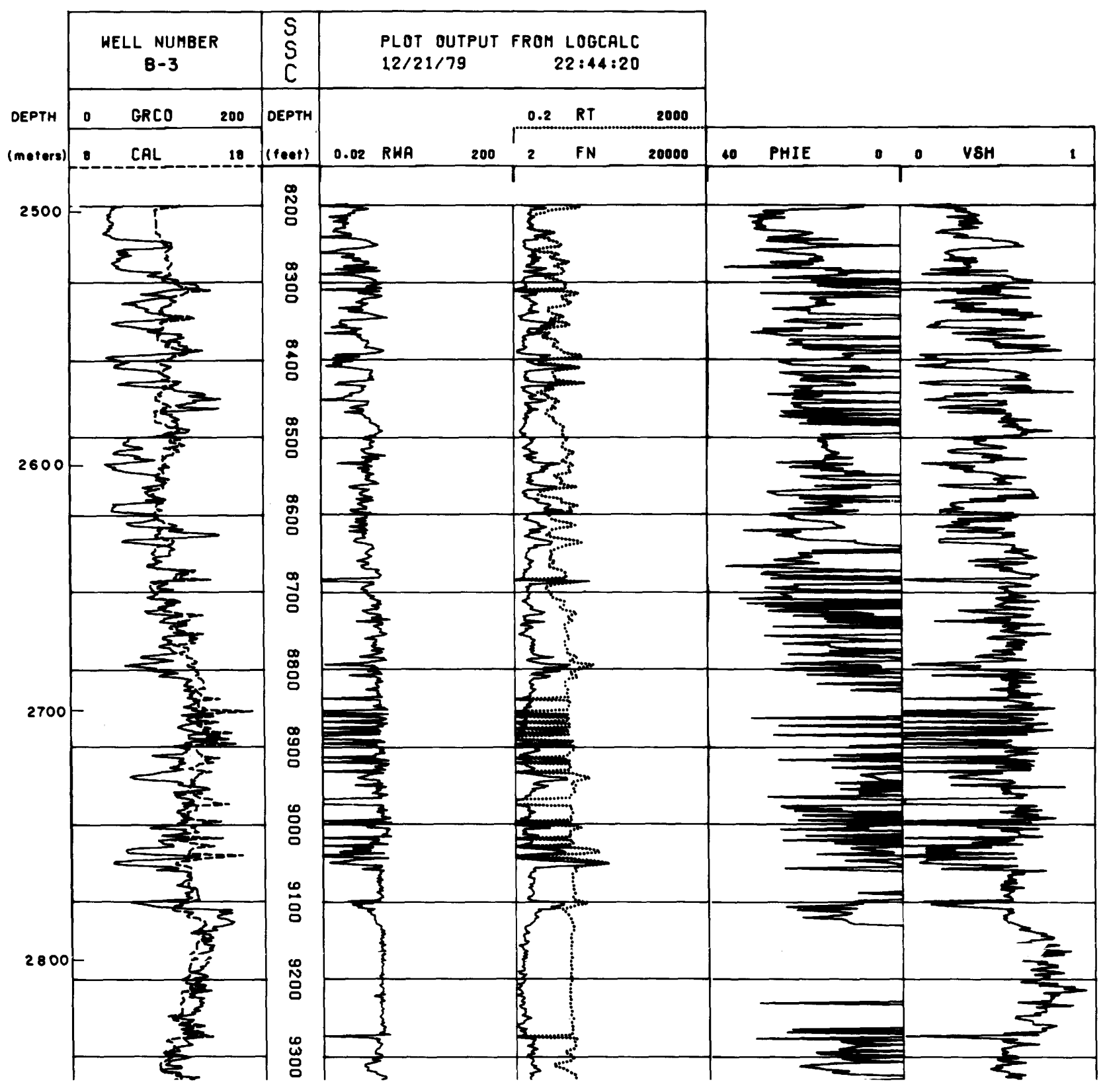




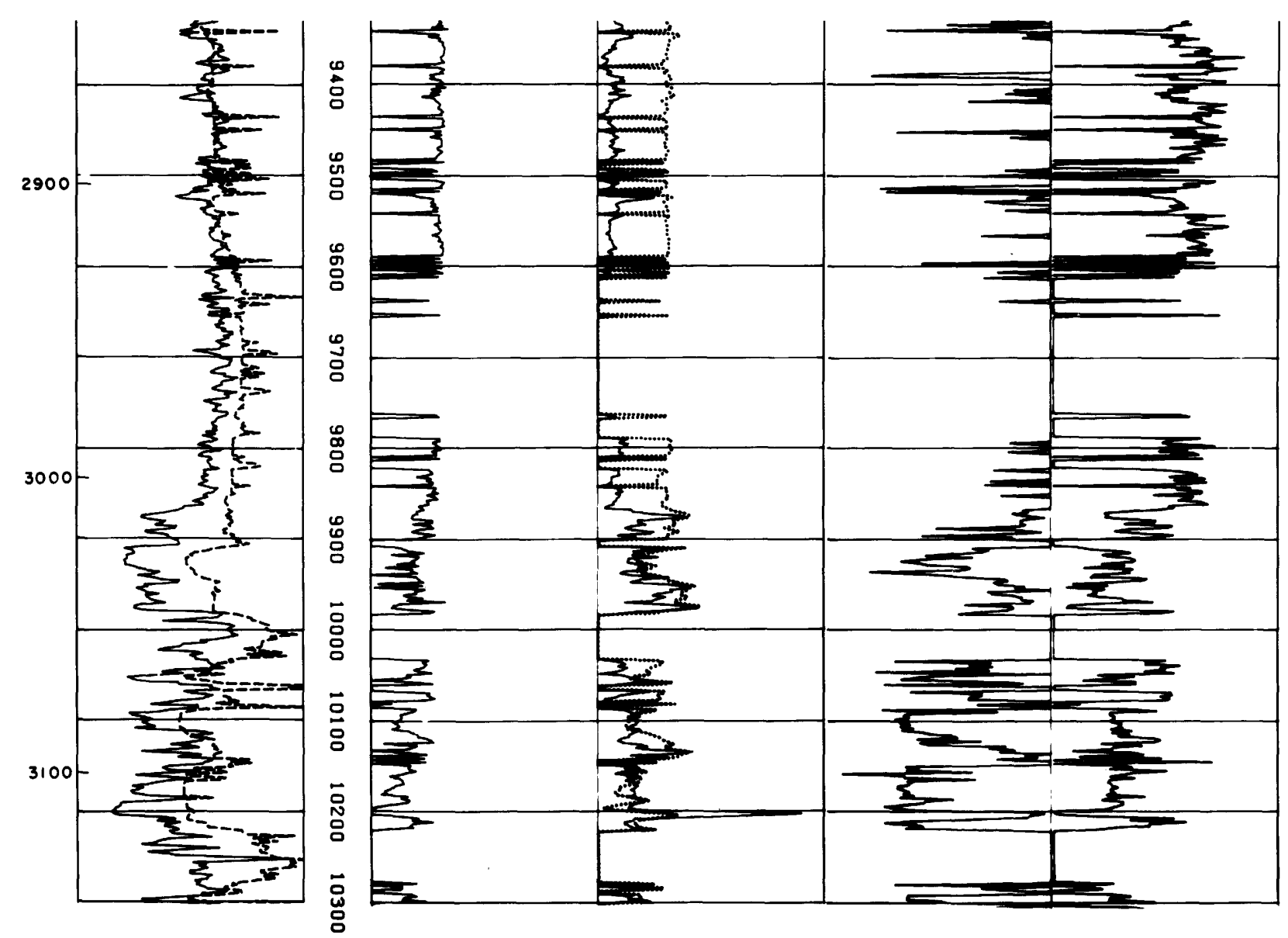

Figure 15.--Results of computer well-1og analysis for the Cost No. B-3 well (SAM7): 8, 200-10,300 ft $(2,499-3,139 \mathrm{~m})$. The corrected gamma ray (GRCO) and caliper (CAL) values are plotted on track 1. The apparent water resistivity (RWA) is in track 2, true formation resistivity (RT) and neutron formation resistivity factor (FN) are in track 3, effective porosity (PHIE) is in track 4, and shale content (VSH) is in track 5. 


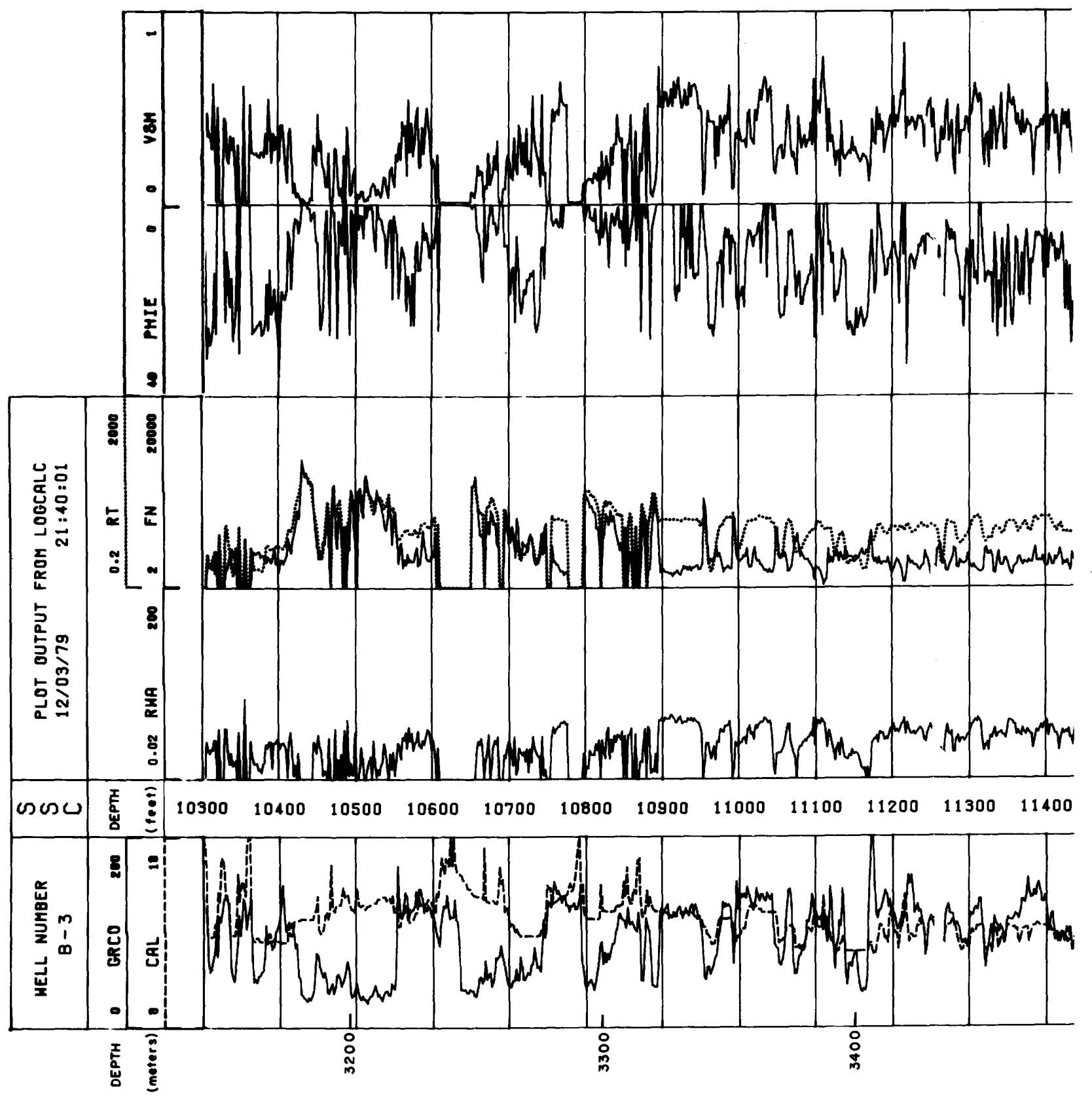



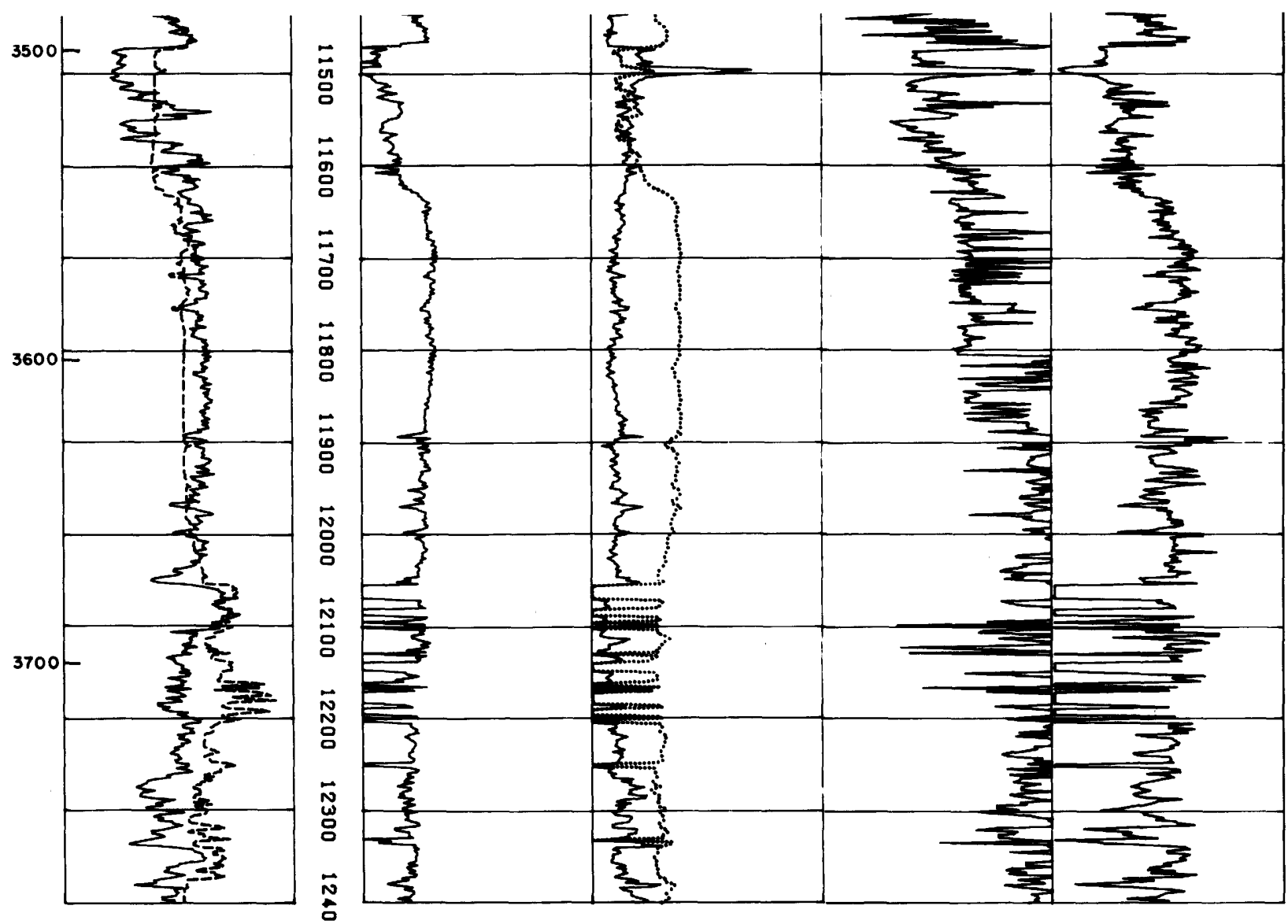

Figure 16.--Results of computer well-log analysis for the COST No. B-3 well (SAM7): 10, 300-12,400 ft $(3,319-3,779 \mathrm{~m})$. The corrected gamma ray (GRCO) and callper (CAL) values are plotted on track 1. The apparent water resisitivity (RWA) is in track 2, true formation resistivity (RT) and neutron formation resisitivity factor (FN) are in track 3, effective porosity (PHIE) is in track 4, and shale content (VSH) is in track 5. 


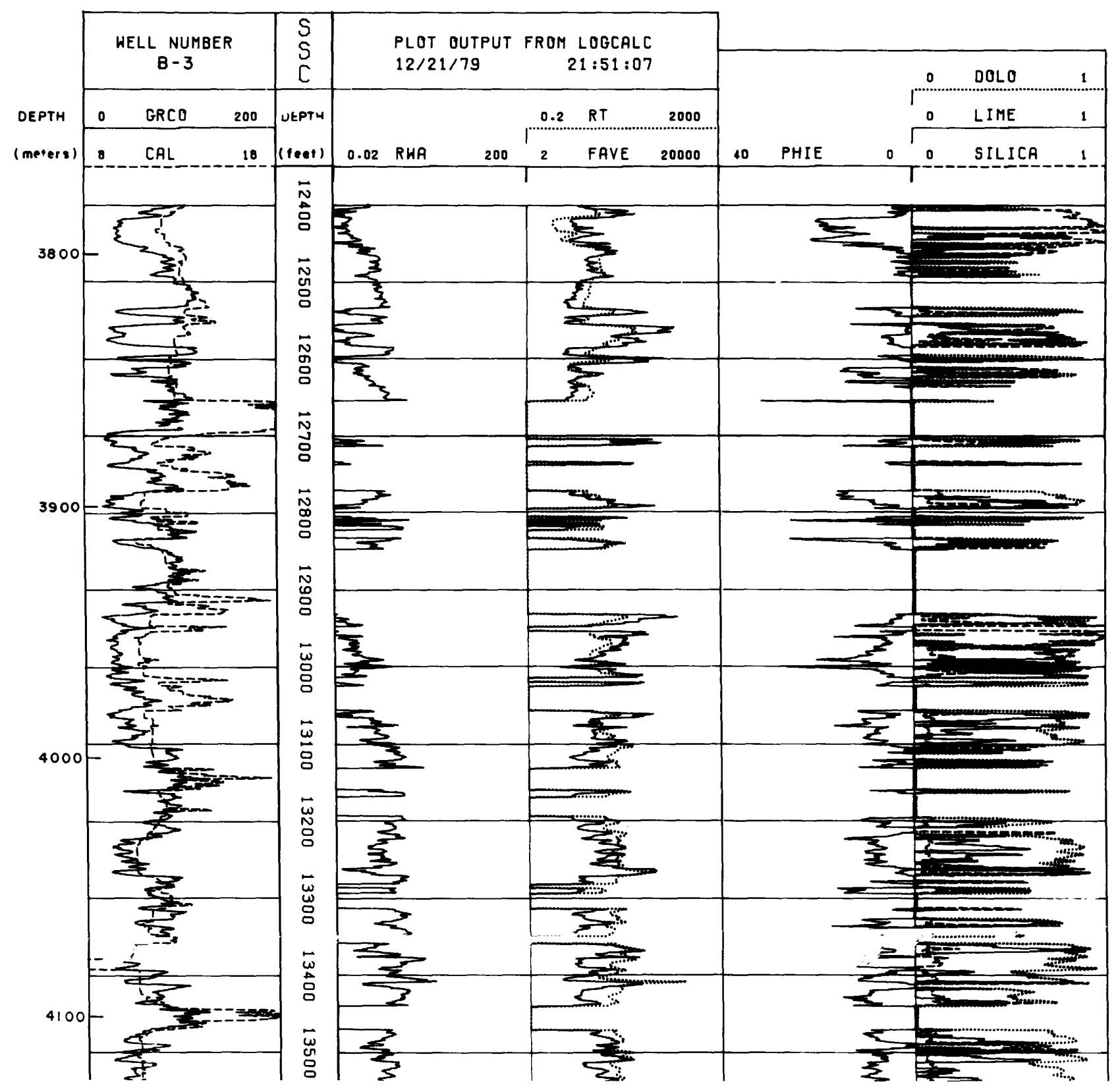




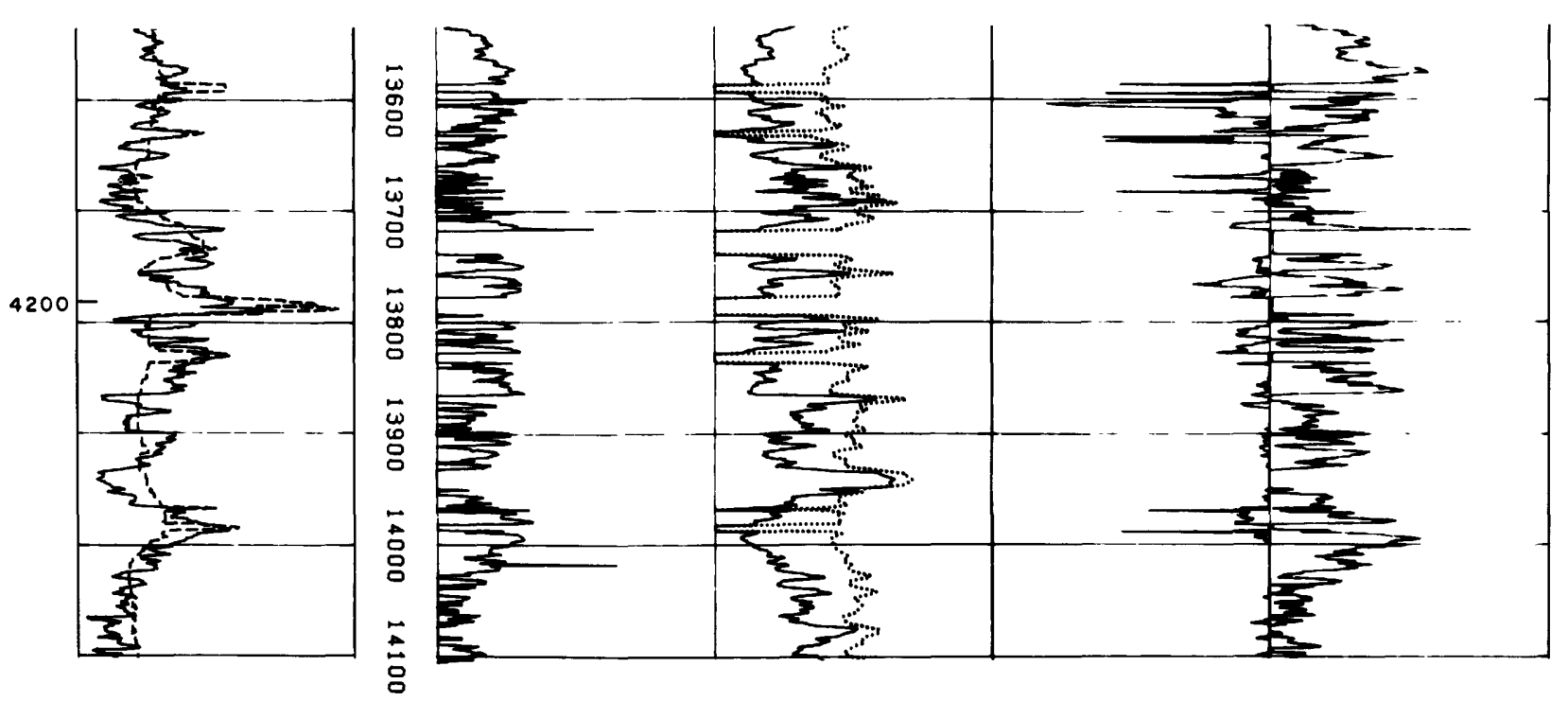

Figure 17.--Results of computer wel1-log analysis for COST No.B-3 well (SAM7): $12,400-14,100 \mathrm{ft}$ $(3,779-4,297 \mathrm{~m})$. The corrected gamma ray (GRCO) and caliper (CAL) values are plotted on track 1. The apparent water resistivity (RWA) is in track 2, true formation resistivity (RT) and neutron formation resistivity factor (FN) are in track 3, effective porosity (PHIE) is in track 4, and shale content (VSH) is in track 5. 


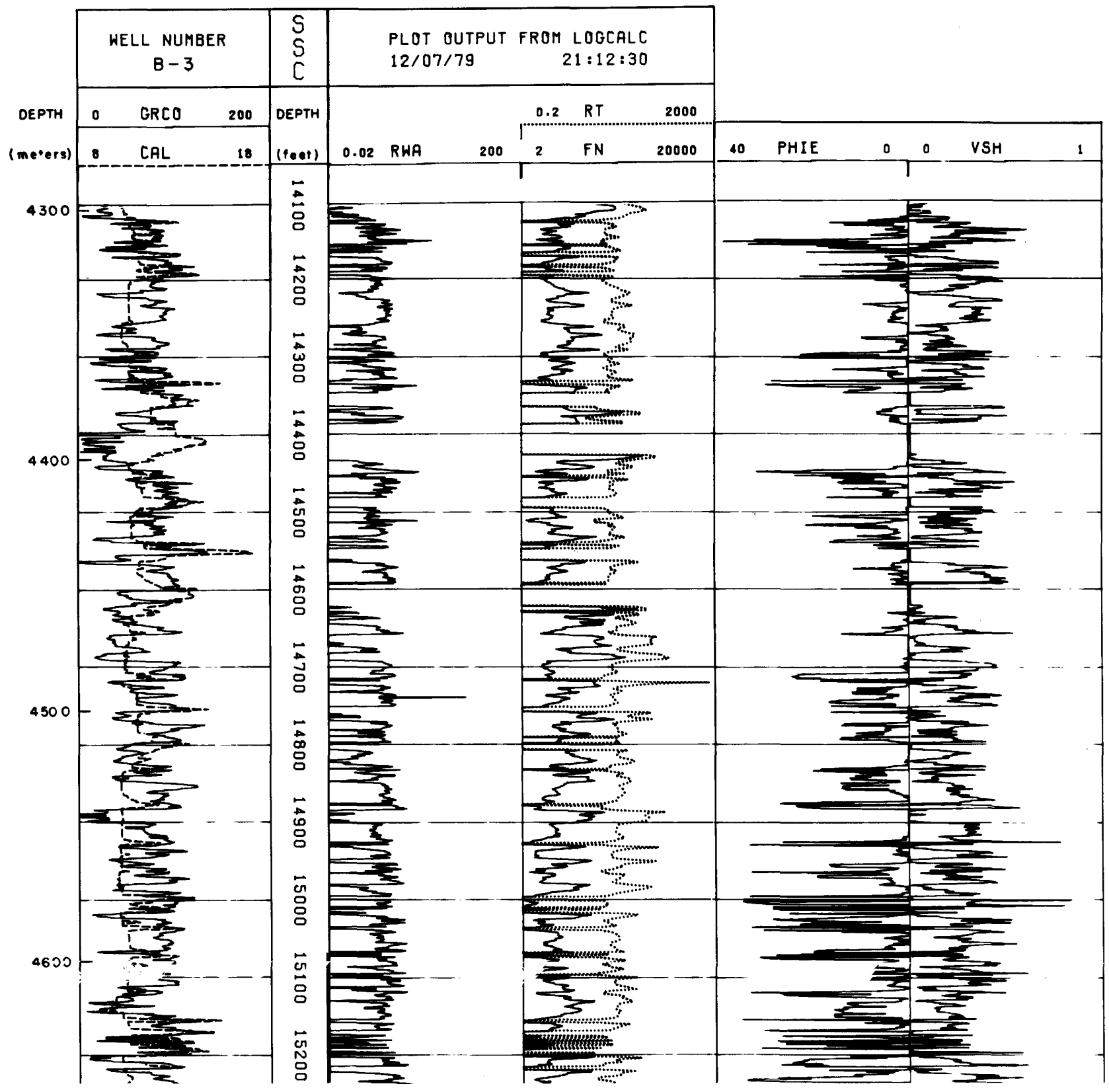




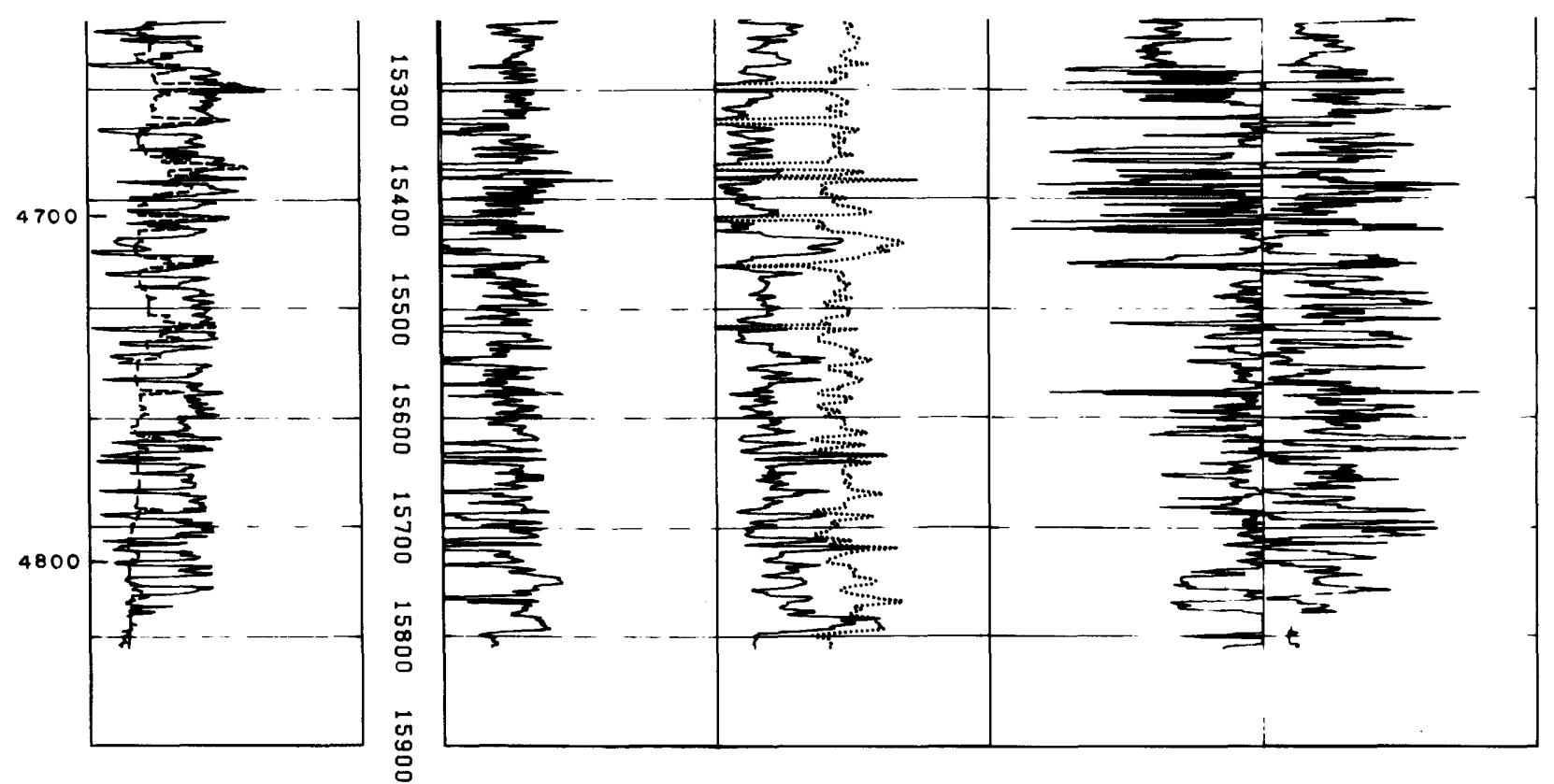

F1gure 18.--Results of computer well-log analys1s for COST No. B-3 well (SAM7): $14,100-15,810 \mathrm{ft}$ $(4,297-4,818 \mathrm{~m})$. The corrected gamma ray (GRCO) and caliper (CAL) values are plotted on track 1. the apparent water resistivity (RWA) is in track 2, true formation resistivity (RT) and neutron formation resistivity factor (FN) are in track 3, effectived porosity (PHIE) is in track 4, and shale content (VSH) is in track 5. 


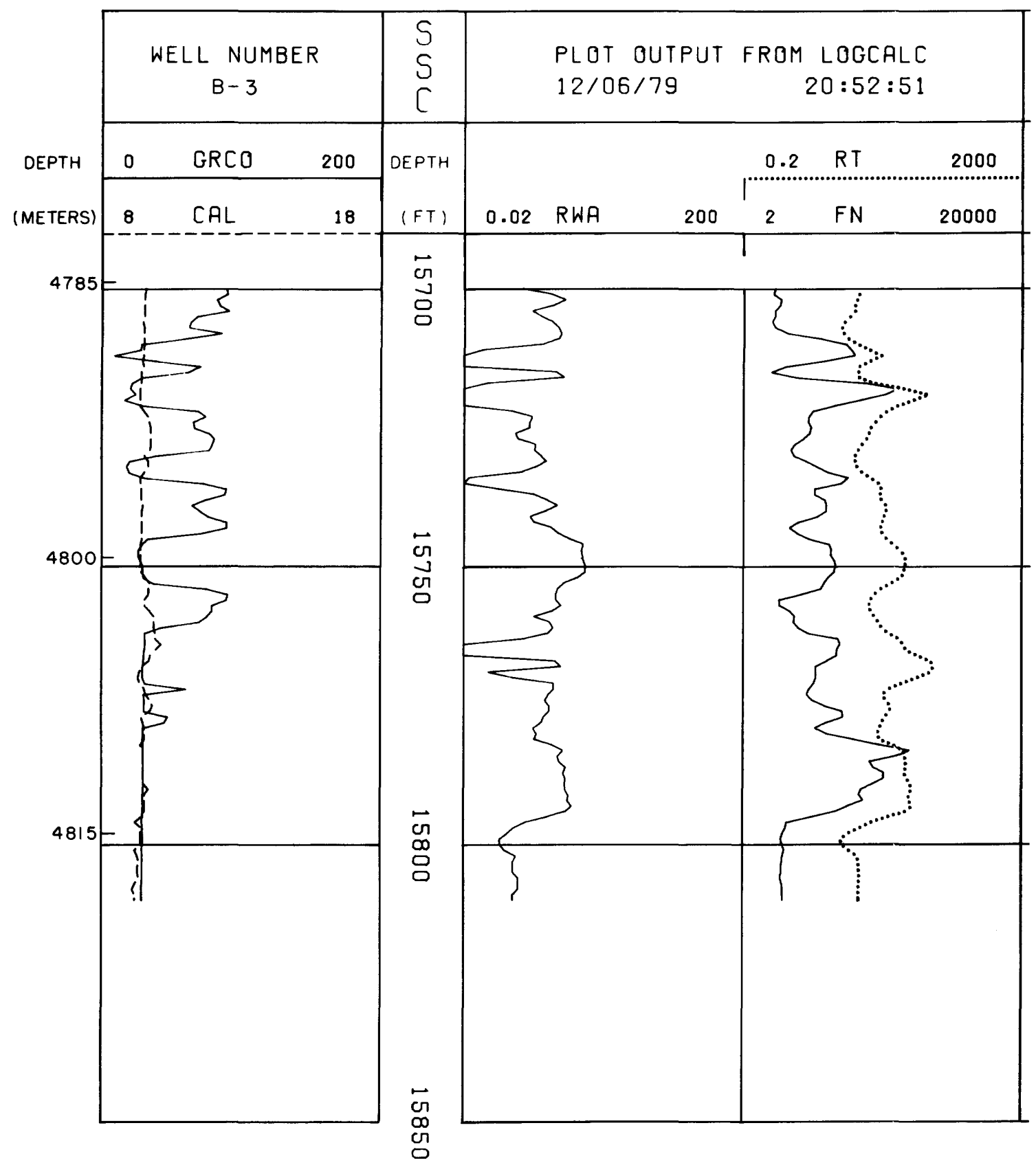

Figure 19.--Results of computer well-log ana$(4,785-4,818 \mathrm{~m})$. The corrected on track 1 . The apparent water tivity (RT) and neutron formation sity (PHIE) is in track 4, and 
PLOT OUTPUT FROM LOGCALC

12/06/79 20:55:37

$\begin{array}{llllll}40 & \text { PHIE } & 0 & 100 & \text { SW } & 0\end{array}$

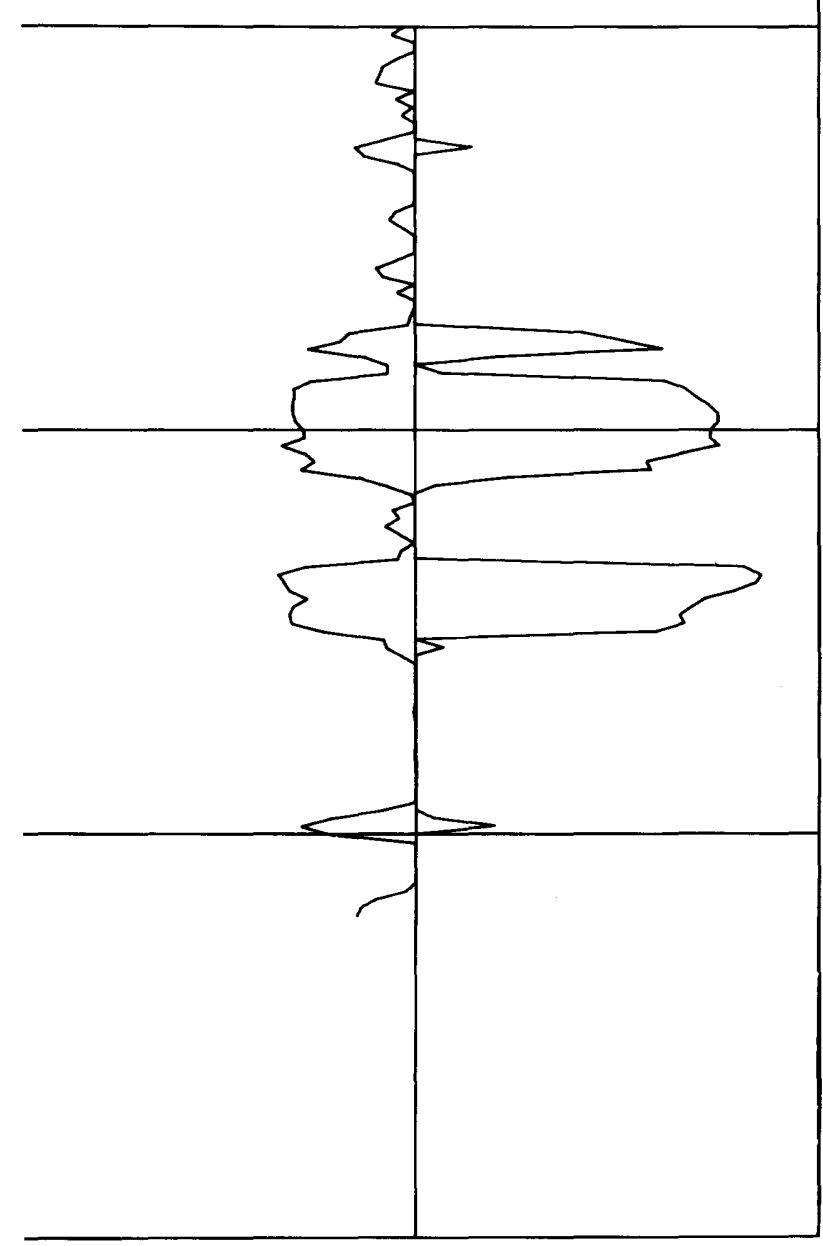

lysis for cosT No. B-3 wel1 (SAM7): $15,700-15,810 \mathrm{ft}$ gamma ray (GRCO) and caliper (CAL) values are plotted resistivity (RWA) is in track 2, true formation resisresistivity factor (FN) are in track 3, effective poroshale content (VSH) is in track 5 . 


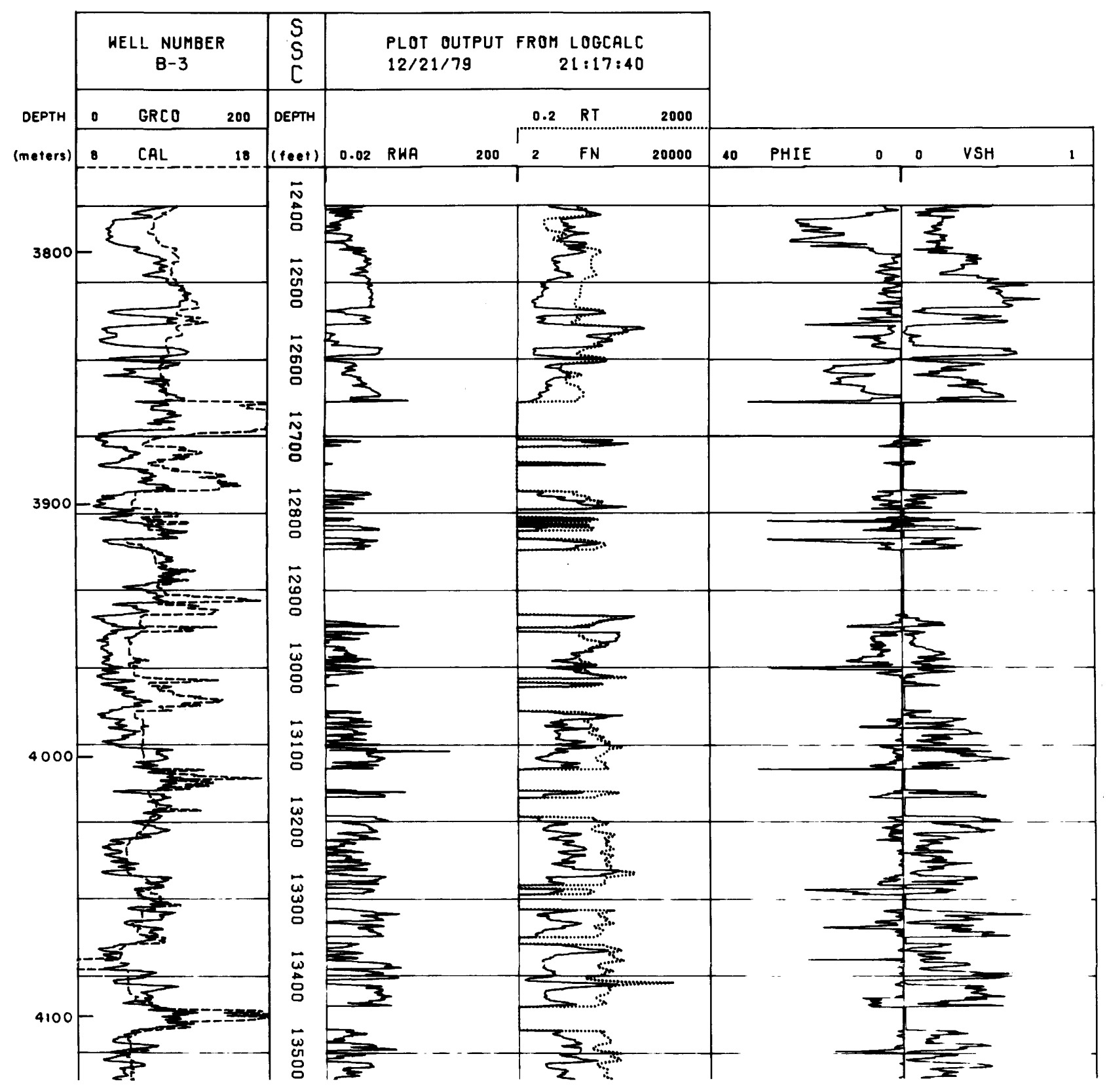



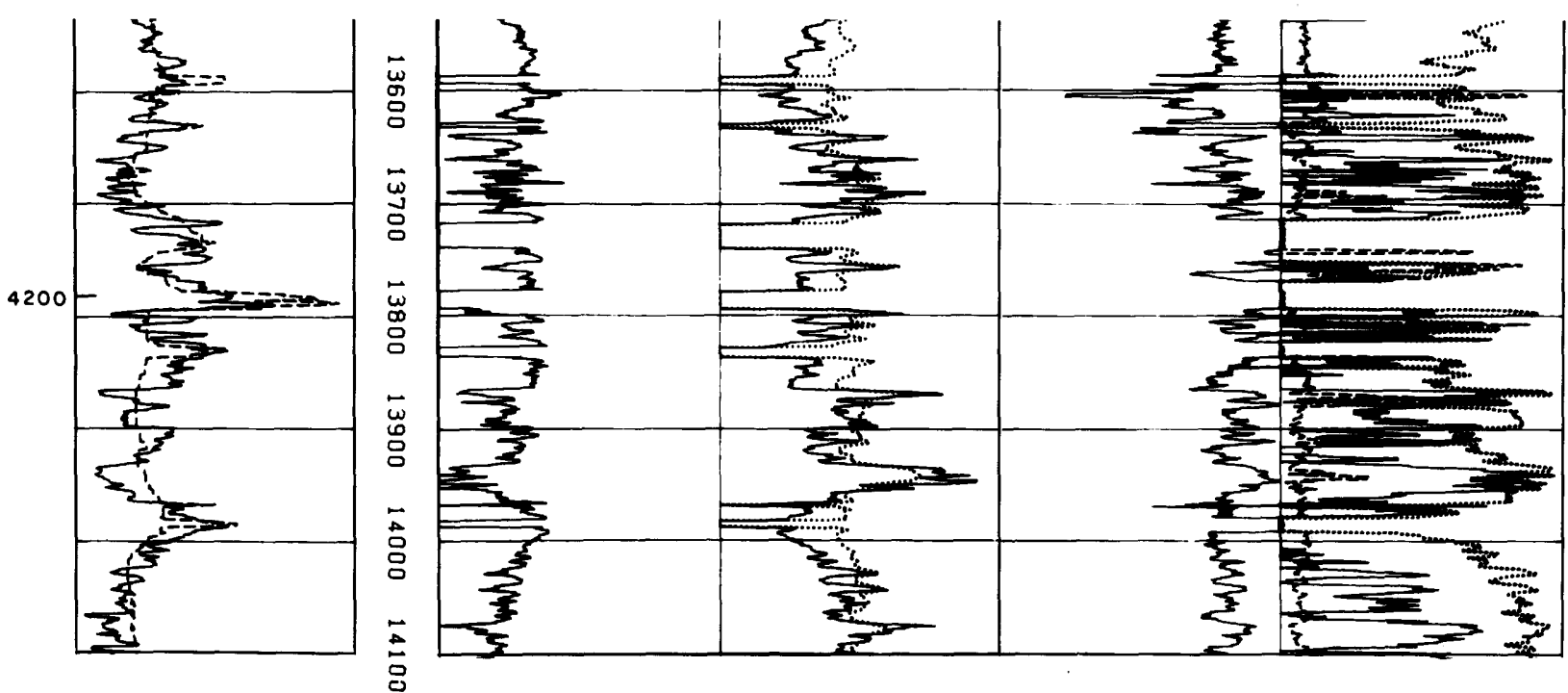

Figure 20.--Results of computer well-1og analysis for COST No. B-3 wel1 (CAM7): $12,400-14,100 \mathrm{ft}$ $(3,779-4,297 \mathrm{~m})$. The corrected gamma ray (GRCO) and caliper (CAL) values are plotted on track 1. The apparent water resistivity (RWA) is in track 2, true formation resistivity (RT) and neutron formation resistivity factor (FN) are in track 3 , effective porosity (PHIE) is in track 4, and shale content (VSH) is in track 5. 


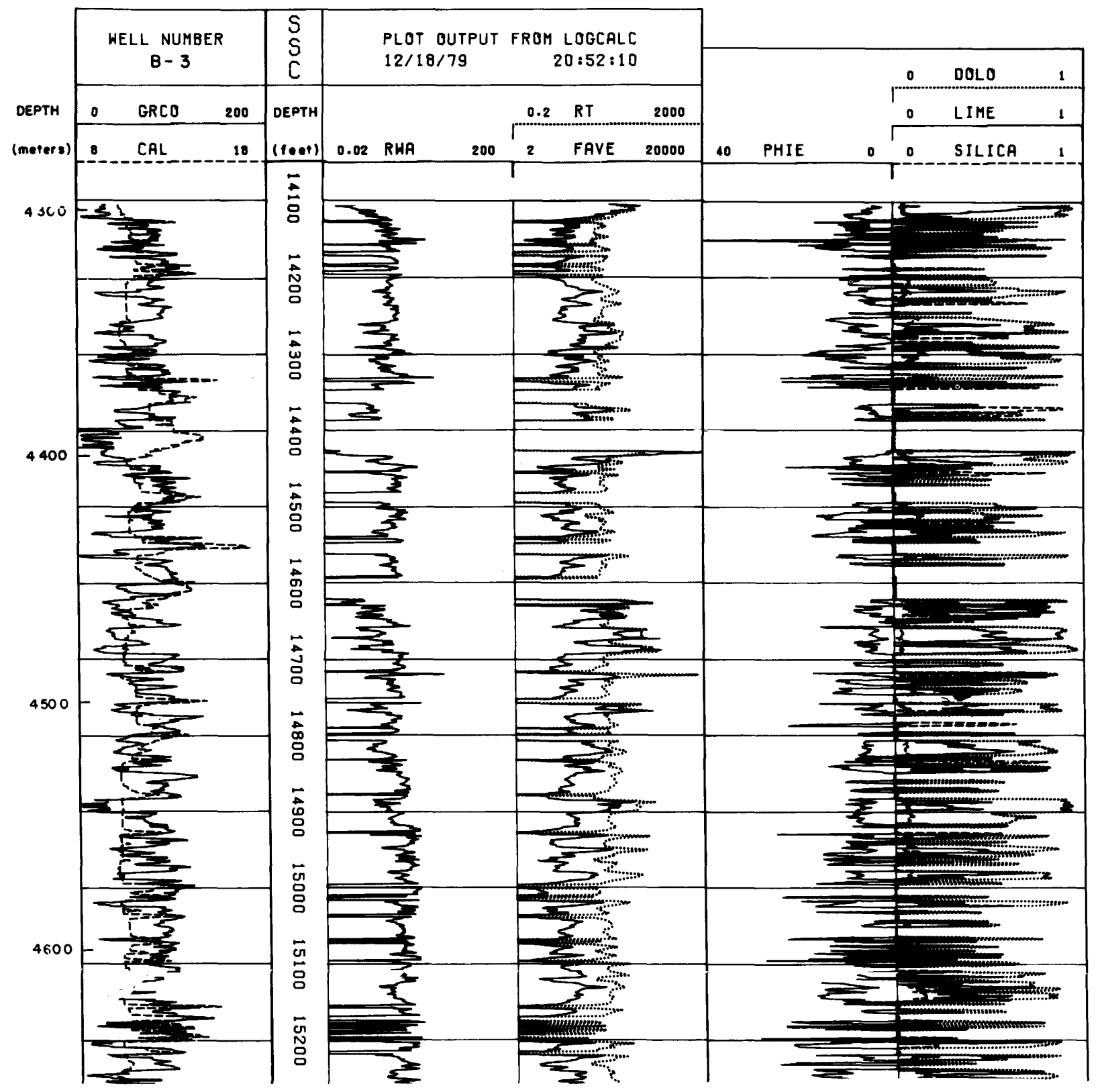



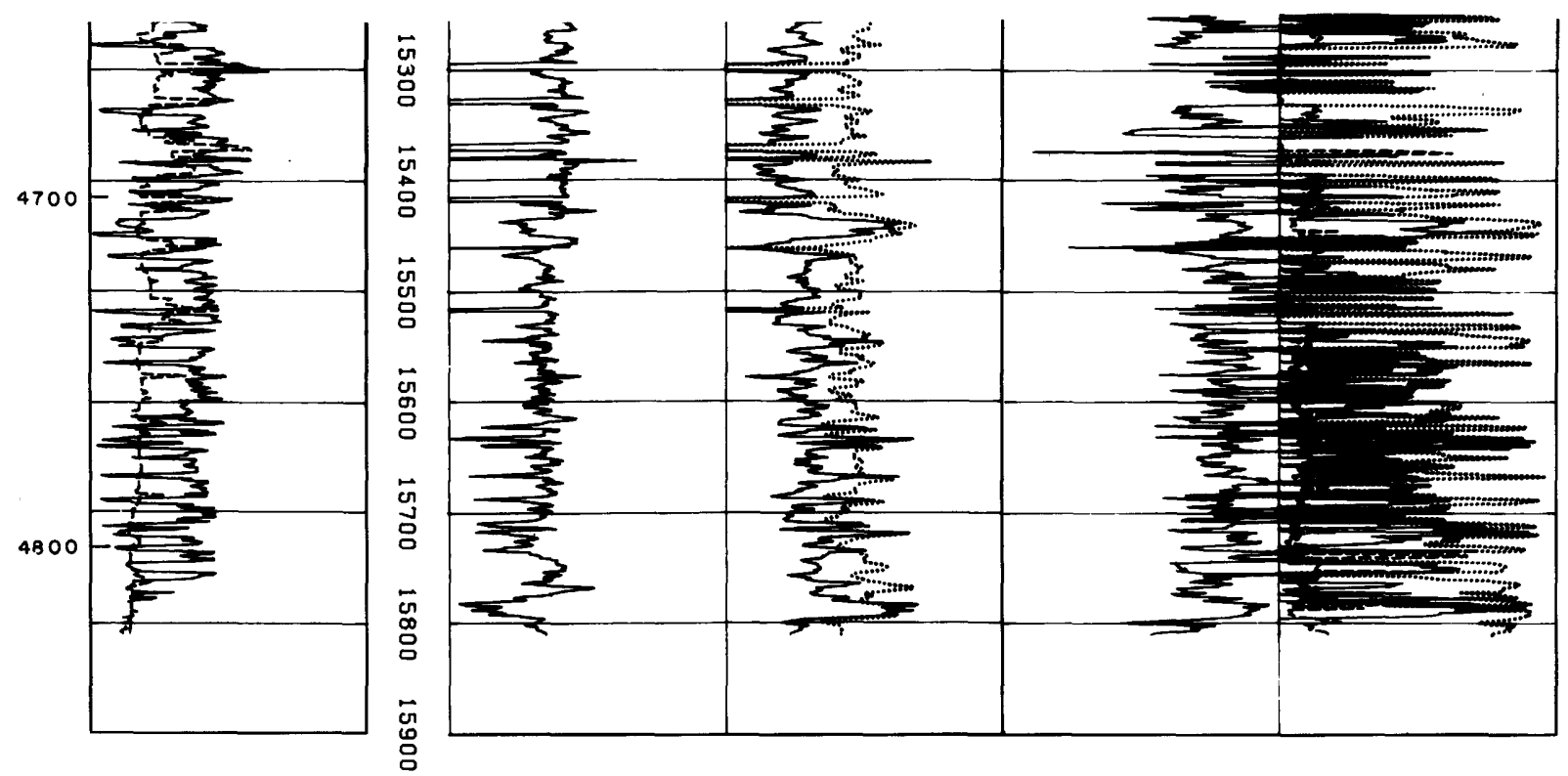

Figure 21.--Results of computer well-log analysis for COST No. B-3 well (CAM7): $14,100-15,810 \mathrm{ft}$ $(4,297-4,818 \mathrm{~m})$. The corrected gamma ray (GRCO) and caliper (CAL) values are plotted on track 1. The apparent water resistivity (RWA) is in track 2, true formation resistivity (RT) and neutron formation resistivity factor (FN) are in track 3, effective porosity (PHIE) is in track 4, and shale content (VSH) is in track 5. 
FORAMINIFERAL STRATIGRAPHY,

PALEOENVIRONMENTS, AND DEPOSITIONAL

CYCLES IN THE OUTER BALTIMORE

CANYON TROUGH

C. Wylie Poag

\section{INTRODUCTION}

At least eight studies of foraminifers in the offshore portion of the Baltimore Canyon trough have now been published (Hathaway and others, 1976, 1979; 01sson, 1978, Poag, 1977, $1978,1979 ;)$, and three others have been openfiled by the U.S. Geological Survey (Hathaway and others, 1976; Smith and others, 1976; and Steinkraus, 1979). Most of the 17 nonexploration drill holes in the offshore part of the trough have penetrated no deeper than $1,000 \mathrm{ft}$ $(305 \mathrm{~m})$ beneath the sea floor and have recovered only Cenozolc (mainly Miocene and younger) sedimentary rocks (fig. 22; Poag, 1978). Completion of the $\operatorname{cosT}$ No. B-3 well has provided a second record (in addition to the COST No. B-2 well) of Middle(?) and Upper Jurassic and Cretaceous rocks in the outer part of the trough. This report provides a preliminary biostratigraphic and paleoenvironmental analysis of the planktic and benthic foraminiferal assemblages recovered in the CosT No. B-3 well (fig. 23). Because the report is preliminary, later studies may modify some of the interpretations formulated herein, but the major conclusions will probably not be greatly altered. The $\mathrm{B}-3$ results are compared to a revised analysis of the B-2 well (f1g. 24; Poag, 1977, 1978) and are placed in regtonal stratigraphic and structural context by plotting them on a 48-channel common-depth-point seismic reflection profile (fig. 25).

The biostratigraphic zonation is based primarily on planktic foraminifers in the Upper Cretaceous and Cenozoic rocks, but radiolarians provide secondary biochronology in the blogenicsilica-rich Miocene section. Benthic foraminifers provide age estimates for the Early Cretaceous and Middle(?) and Late Jurassic rocks. Paleoenvironmental interpretations are based on benthic foraminiferal associations, predominance of benthic genera, species diversity, absolute abundance of all specimens, and relative abundance of planktic specimens.
The foraminiferal zonations and time scales of Berggren and van Couvering (1974), Blow (1969), Hardenbol and Berggren (1978), ard Stainforth and others (1977) are used for the Cenozolc; those of Ascoli (1976), Pessagno (1967), and van Hinte (1976a, b), for the Cretaceous and Jurassic. The radiolarian interpretations are based on the work of Kling (1978), and Riedel and Sanf111ppo (1978).

Considerable uncertainty exists about the precise position of some of the stare boundaries in the Lower Cretaceous and Jurassic intervals. (See Valentine, this volume; Ascoli, 1976.) The biostratigraphic interpretations are compatible, as far as possible, with the work of Ascoli (1976), who thoroughly studied the foraminiferal sequences in the Scotian Basin and calibrated them with the palynomorph studies of colleagues who analyzed the same wells (Bujak and Williams, 1977; Williams, 1975).

Samples from the COST No. B-3 well are, like those of the CosT No. B-2 well, mainly rotary-ditch cuttings, taken every 10-30 ft (3-9 m) beginning at $3,810 \mathrm{ft}(1,161 \mathrm{~m})$ below the Kelly Bushing ( $\mathrm{KB}$ was $42 \mathrm{ft}$ or $12.8 \mathrm{~m}$ above sea level). One hundred and five sidewall cores were also taken for foraminiferal studies in the $\operatorname{cosT}$ No. B-3 we11, and all of thom have been examined through the courtesy of International Biostratigraphers, Inc. (see Amato and Simonis, 1979, pl. 2, for location of sidewall cores.) The cuttings samples were examined at 30-ft (9m) Intervals throughout the Cenozolc section and at 10-ft (3-m) intervals across the CretaceousCenozolc boundary. The remaining Cretaceous and Jurassic samples were examined, witl few exceptions, at $90-\mathrm{ft}(27-\mathrm{m})$ intervals. (See $\mathrm{f} 1 \mathrm{~g} \cdot 23$ for location of examined samples.) The blostratigraphic sequence is described from the highest (youngest) sample downward, as is customary for drill holes. Conseruently, the first (highest) appearance of diagnostic fossil spectes as cited in the drilled sequence is, in fact, the last chronostratigraphic espearance. 


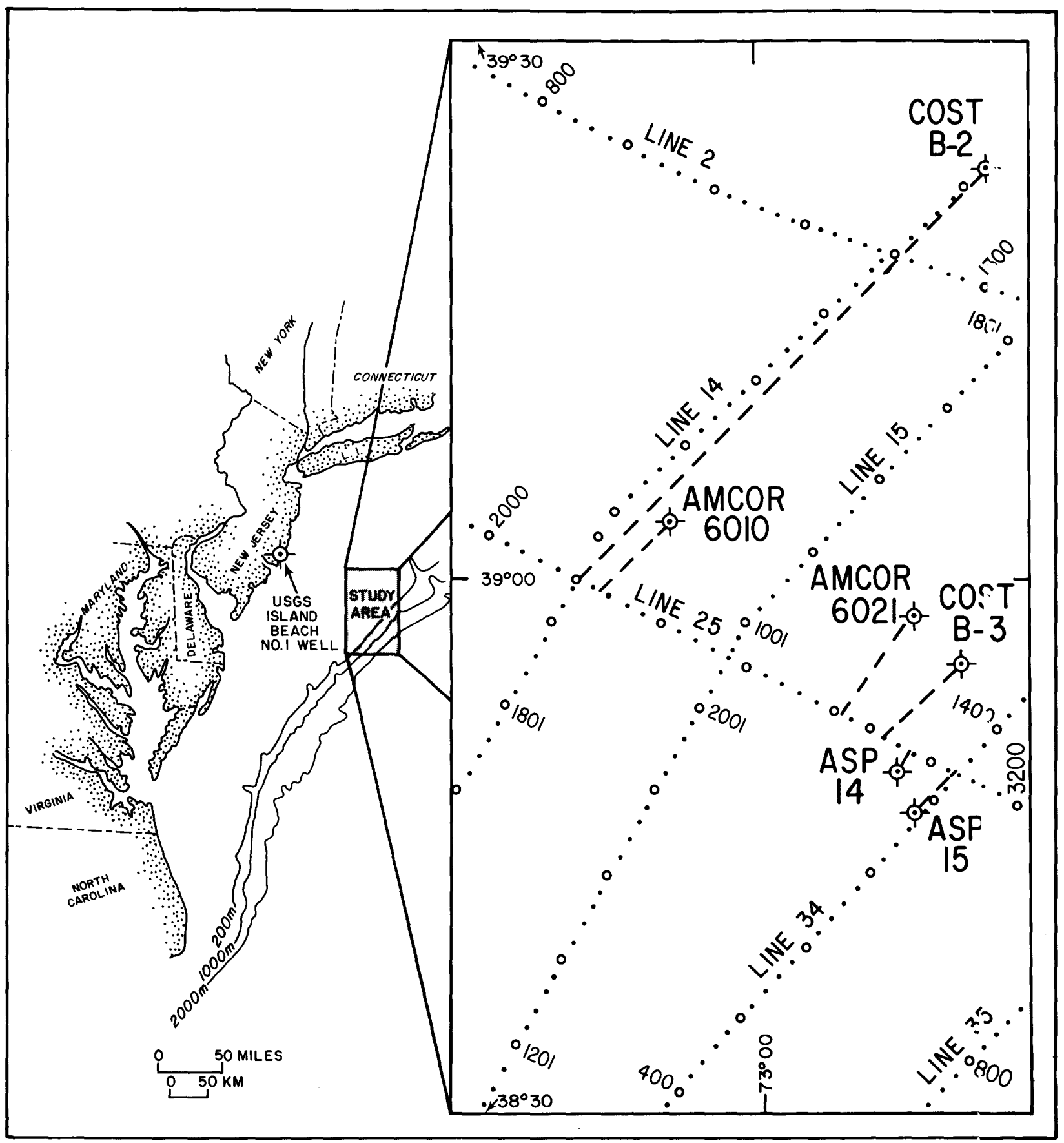

Figure 22.--Location of study area showing USGS seismic lines and dril1 sites in the outer part of the Baltimore Canyon trough. AMCOR= USGS Atlantic Margin Coring Project; ASP= Atlant1c Slope Project (Exxon, Chevron, Gulf, and Mobil, 1967); CosT= Continental Offshore Stratigraphic Test (Ocean Production Co., 1976, B-2; Chevron, 1979, B-3). Numbers on seismic lines refer to shot points. Drill sites have been projected approximately along strike to USGS Seismic Line 25. (See fig. 25.) 

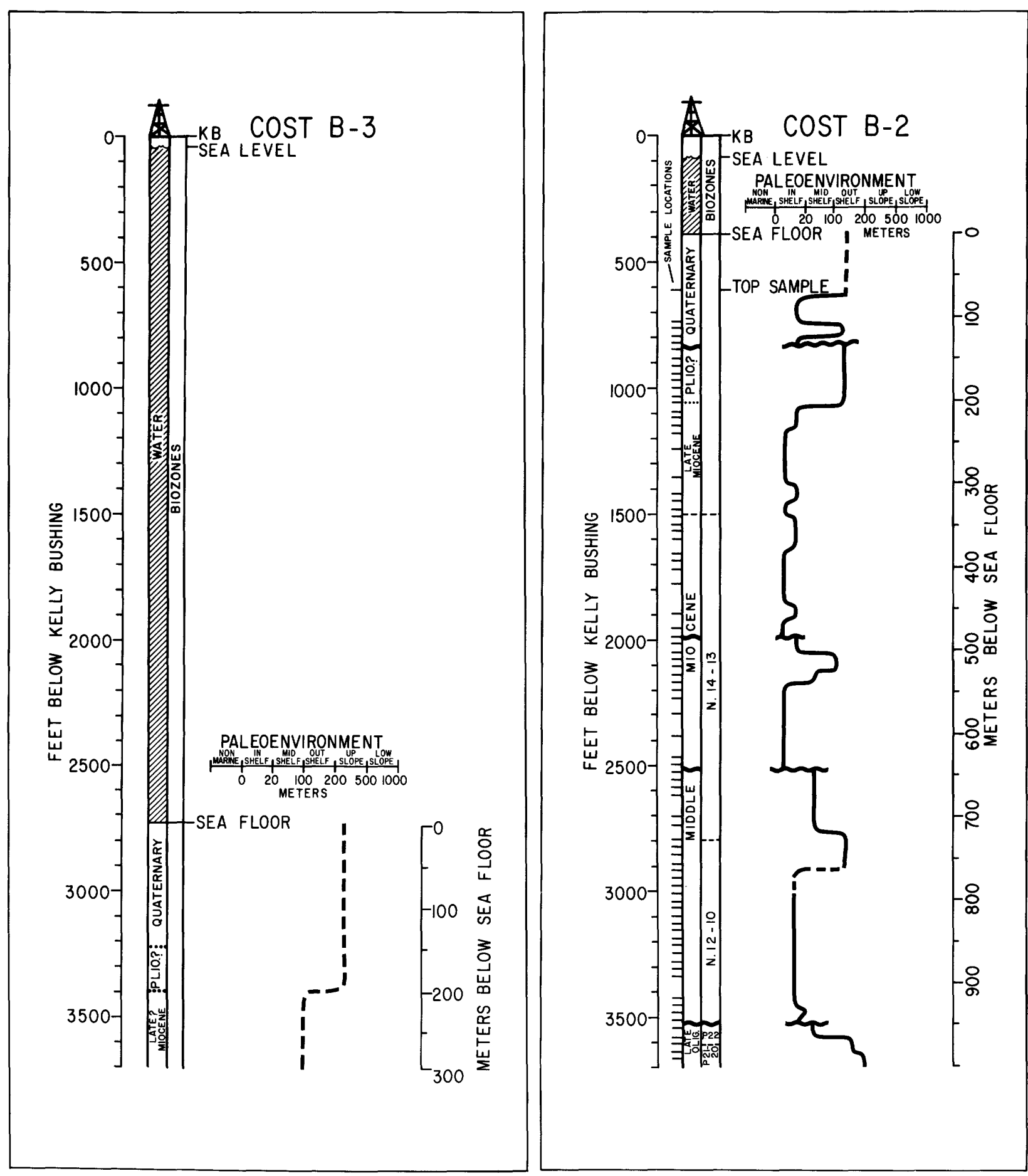

Figure 23.--Biostratigraphic column of the COST No. B-3 well, showing foramintferal biozones and paleoenvironments. Dashed lines indicate approximate determinations; wavy lines designate hiatuses.

Figure 24.--Biostratigraphic column of the COST No. B-2 well, showing foraminiferal biozones and paleoenvironments. The term "seismic" following a stage name indicates that the stage boundaries have been extrapolated from the B-3 well by means of seismic correlation. The term "palyn" following a stage same indicates that palynomorphs are the basis of the stage or series assignment. 


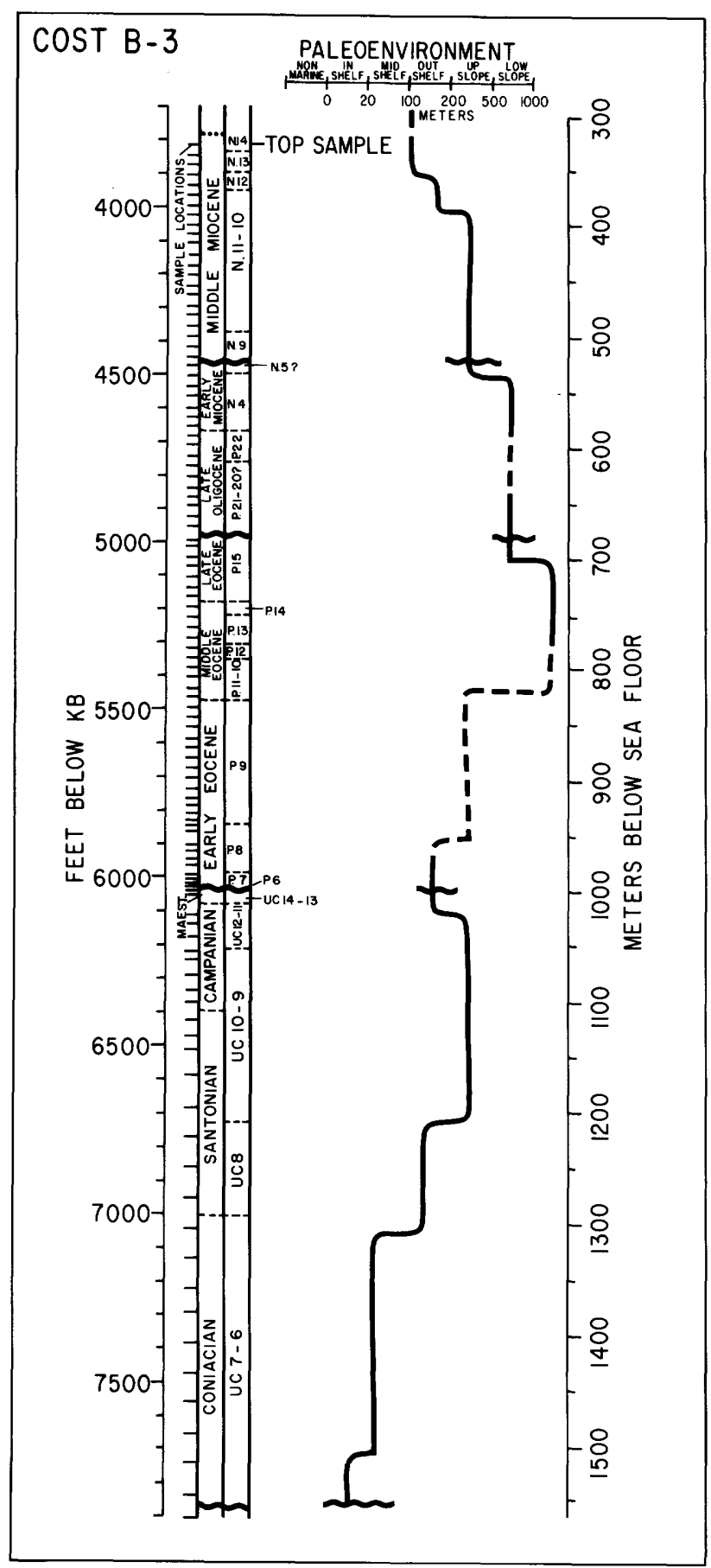

Figure 23.--Biostratigraphic column of the COST No. B-3 we11, showing foraminiferal biozones and paleoenvironments.-Continued

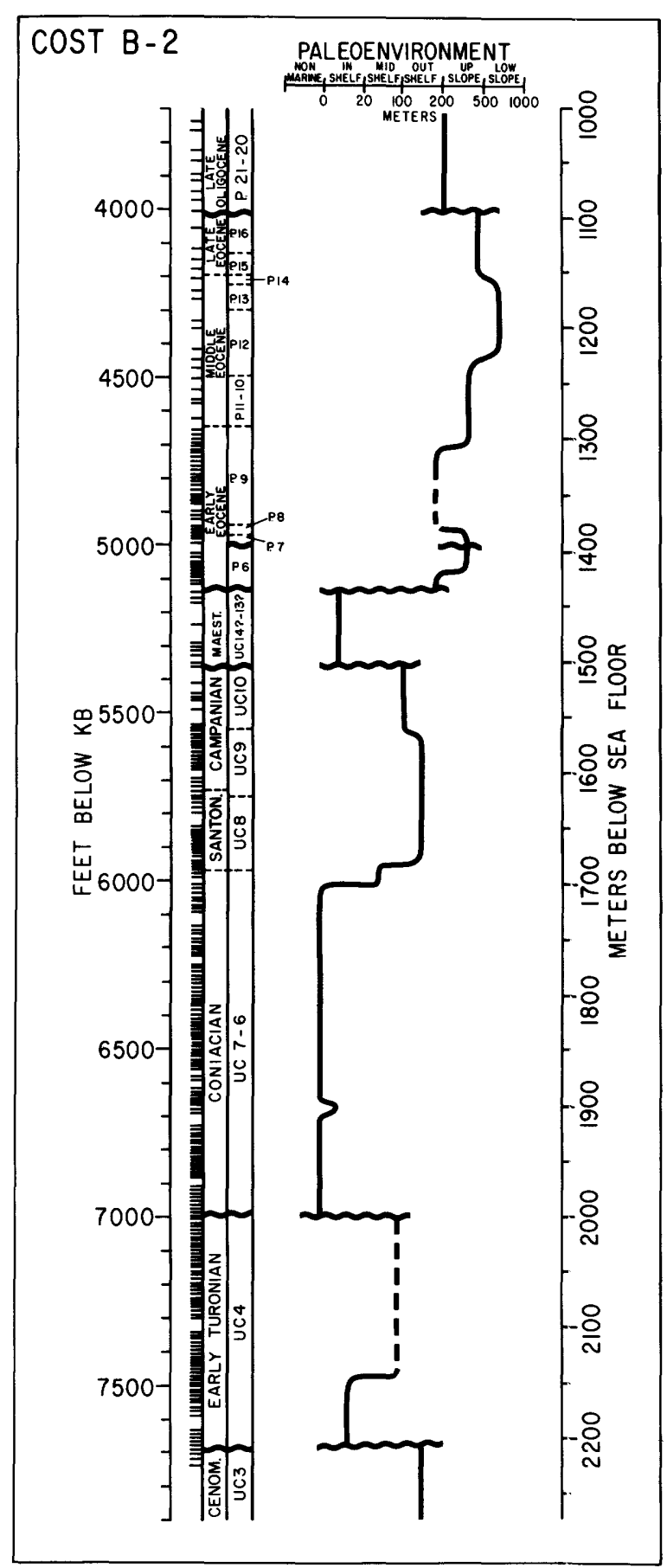

Figure 24.--Biostratigraphic column of the COST No. B-2 we11, showing foraminiferal biozones and paleoenvironments.-Continued 

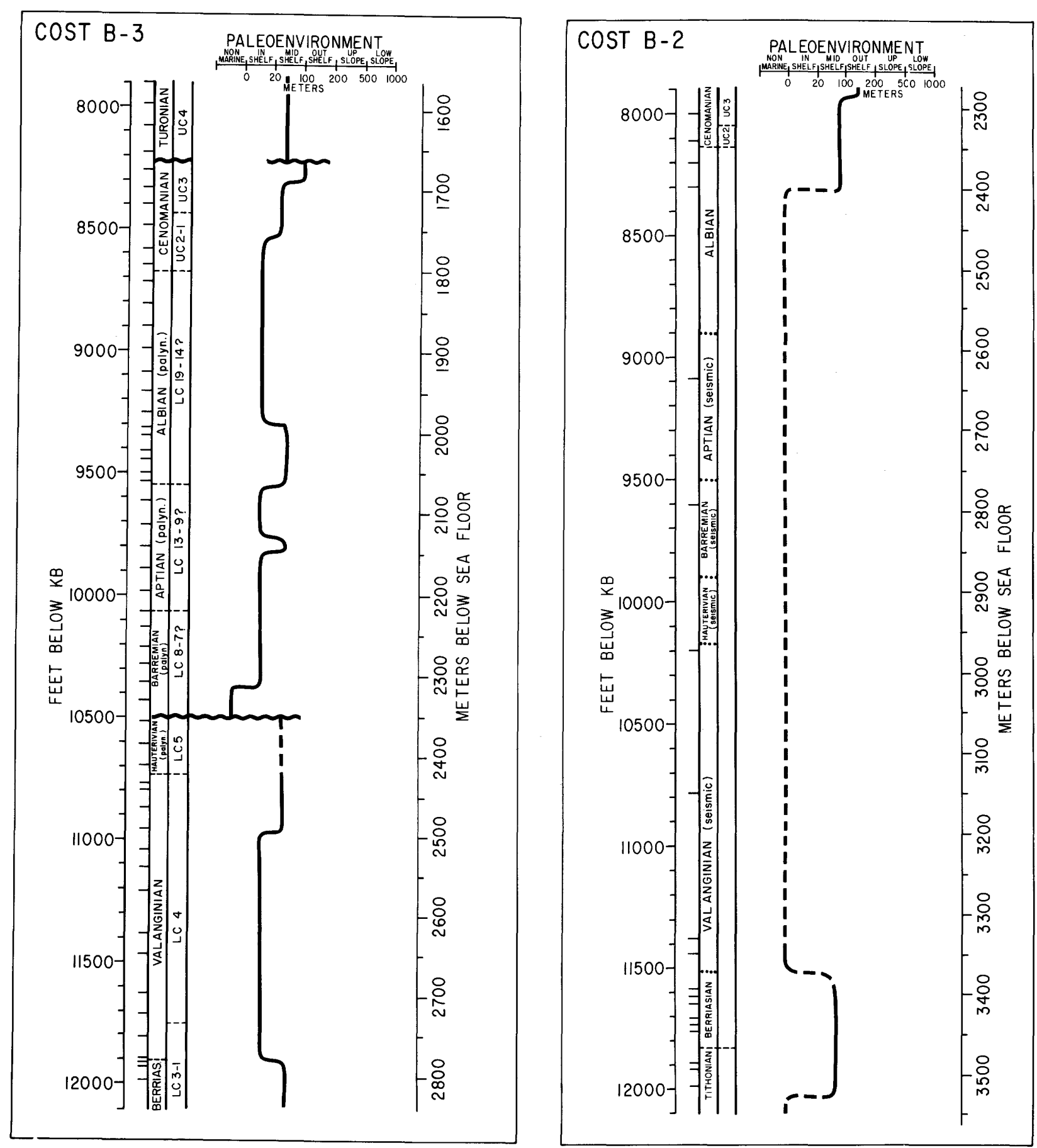

Figure 23.--Blostratigraphic column of the COST No. B-3 wel1, showing foraminiferal biozones and paleoenvironments.-Continued

Figure 24.--Biostratigraphic column of the COST No. B-2 we11, showing foraminiferal biozones and paleoenvironments.-Continued 


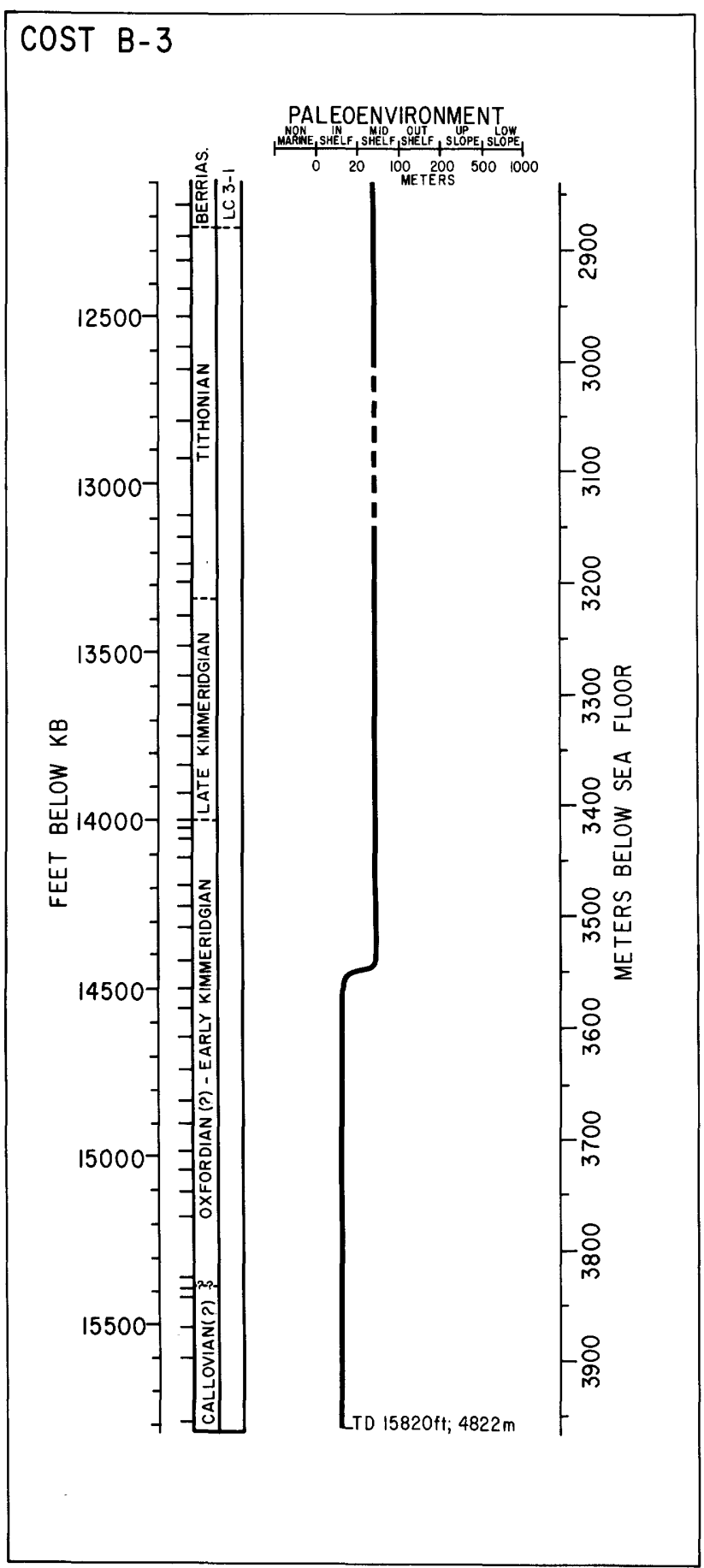

Figure 23.--Biostratigraphic column of the COST No. B-3 well, showing foraminiferal biozones and paleoenvironments.-Continued
COST B-2

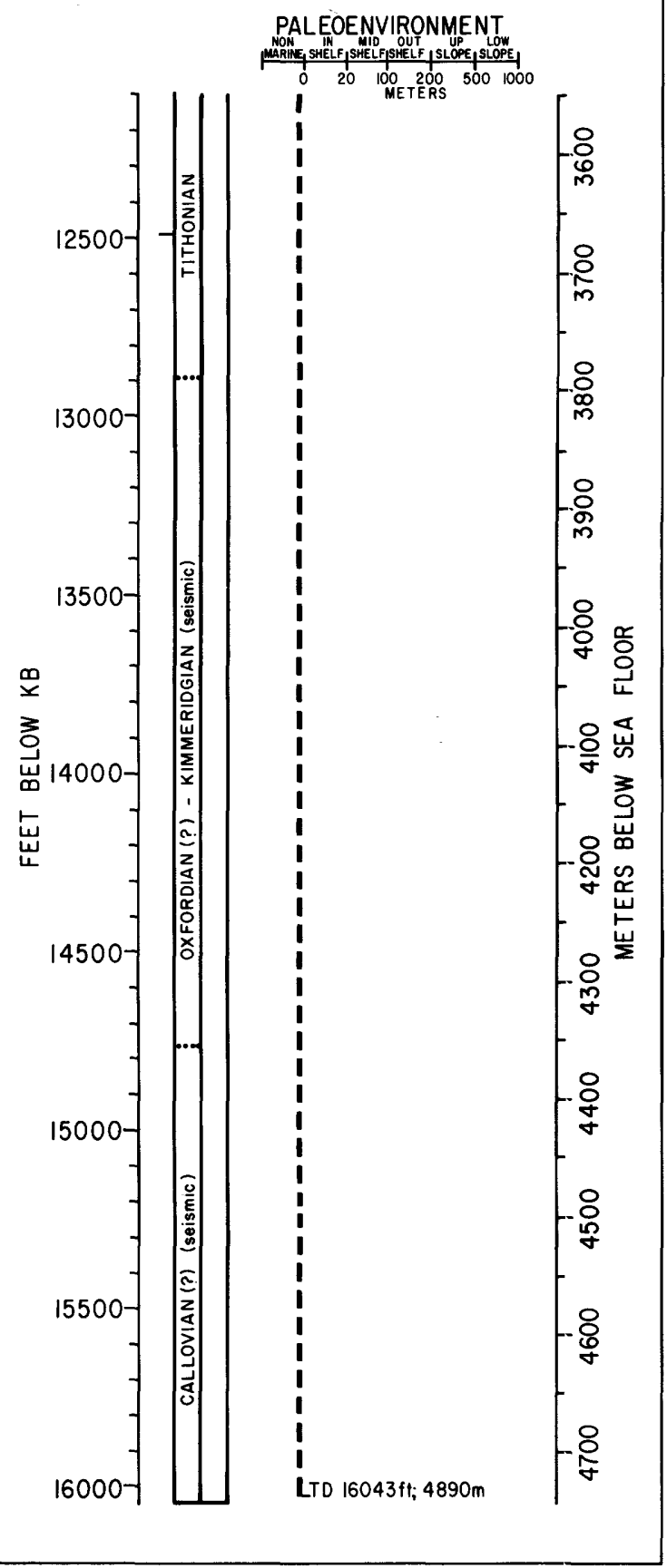

Figure 24.--Biostratigraphic column of the COST No. B-2 we11, showing foraminiferal biozones and paleoenvironments.-Continued 


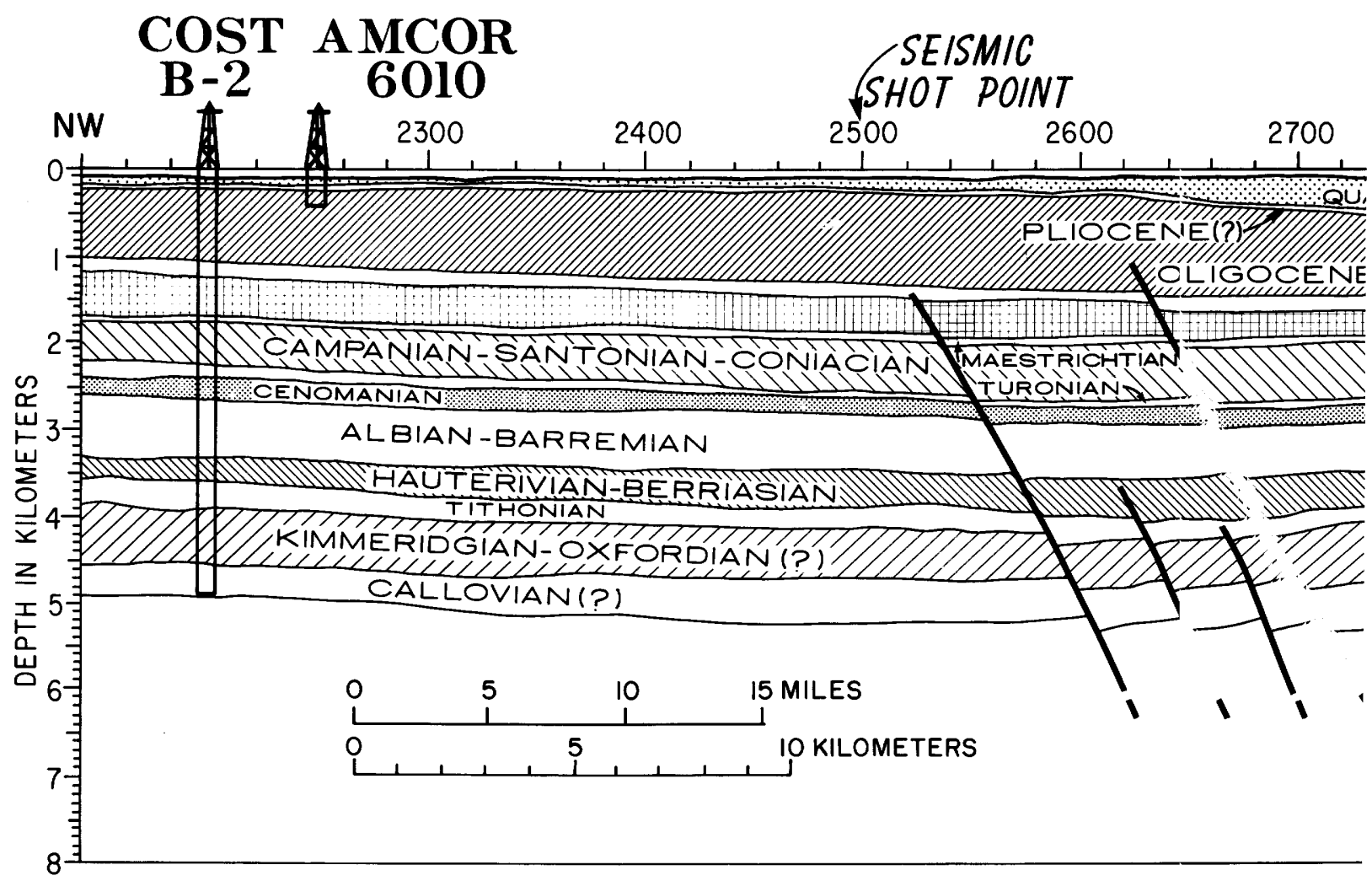

Figure 25.--Geologic cross section along USGS Seismic Line 25. (See fig. 22). Drill sites have volume; Grow, this volume). Biostratigraphic boundaries in the CosT No. B-3 and older rocks) to accommodate the southward dip from the B-3 location; there is no outline of carbonate platform section; these lines are dashed where data is sparse

\section{BIOSTRATIGRAPHY}

Quaternary, Upper Miocene(?), and Pllocene rocks $(2,728$ to $\sim 3,810 \mathrm{ft} ; 831$ to $\sim 1,161 \mathrm{~m})$

No samples were collected shallower than $3,810 \mathrm{ft}(1,161 \mathrm{~m})$ in the $\operatorname{cosT}$ No. $\mathrm{B}-3$ well; but it is certain, on the basis of other core holes and correlation of seismic profiles (fig. 25; Schlee and Grow, this volume), that P1focene and Quaternary rocks were penetrated. The first sample collected (at $3,810 \mathrm{ft} ; 1,161 \mathrm{~m}$ ) is of middle Miocene age, but the presence there of the late Pliocene planktic foraminifer Globorotalia miocenica indicates that upper Pliocene beds lie above 3,810 ft. The Pliocene radiolarian Ommatartus avitus also is in the sample at 3,810 ft. At present, it is not clear exactly how far above $3,810 \mathrm{ft}$ the middle Miocene rocks extend or whether there are any upper Miocene rocks at this locality, but upper
Miocene rocks are tentatively placed between 3,770 and $3,400 \mathrm{ft}(1,149$ and $1,(36 \mathrm{~m})$ on the basis of seismic correlation with the COST No. B-2 we11 (fig. 24).

Middle Miocene rocks $(\sim 3,810$ to $\sim 4,470 \mathrm{ft}$; $\sim 1,161$ to $\sim 1,363 \mathrm{~m}$ )

The youngest sample collected from the B-3 well is of middle Miocene age (fig. 23). The presence of numerous specimens of Turborotalia siakensis indicates that this semple can be stratigraphically no higher than Zone N.14. Bulimina elongata (previously referred to by Poag (1978) as Buliminella gracilis), a typical Miocene benthic species, is al indant; and Cannartus petterssoni, a middle Miocene radiolarian, is frequent.

$$
\text { At } 3,840 \mathrm{ft}(1,170 \mathrm{~m}) \text { specimens of the }
$$




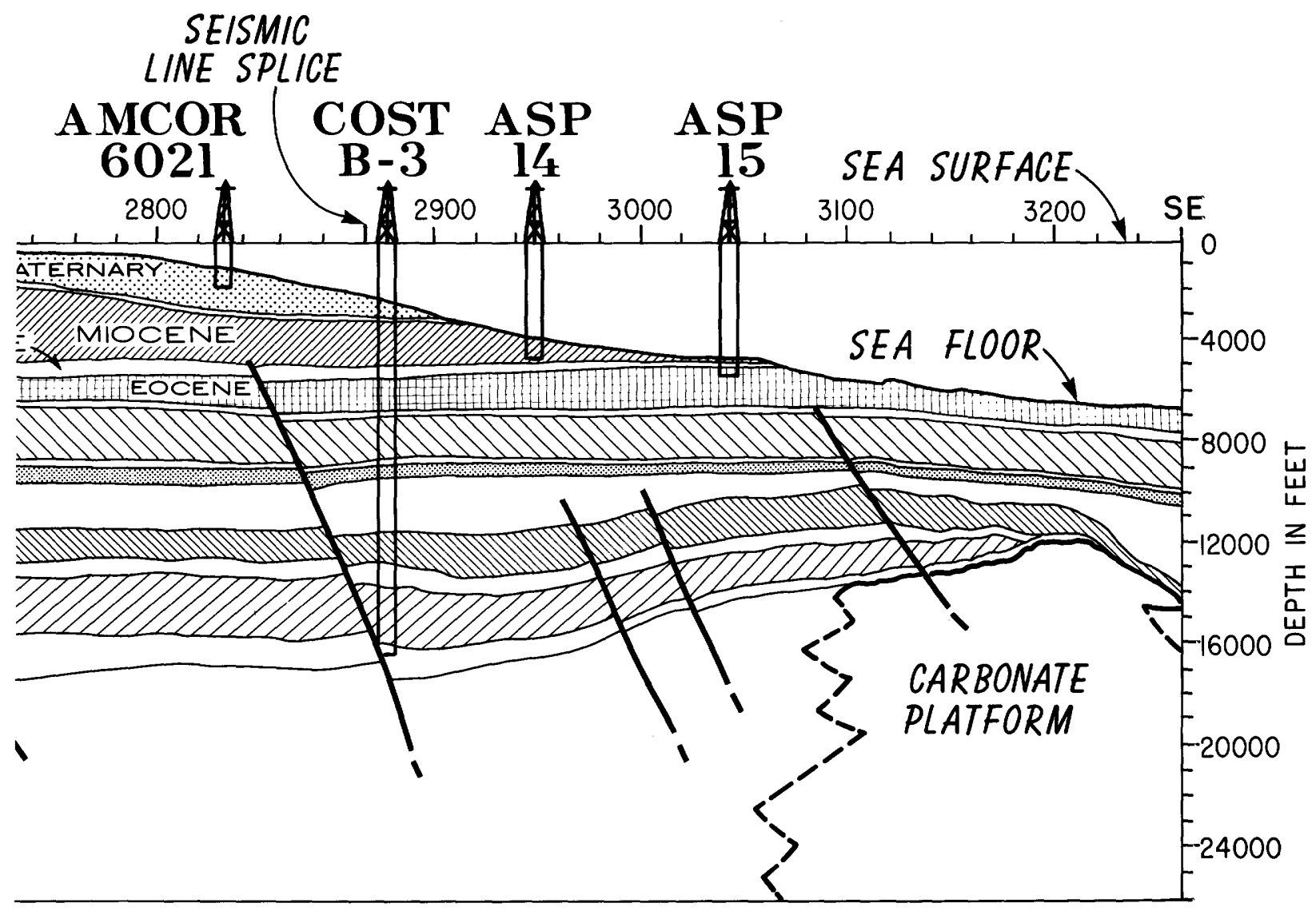

been projected approximately along strike to intersect the seismic line (Schlee and Grow, this we11 have been systematically shifted downward approximately $650 \mathrm{ft}$ (200 m) (for the 01 igocene southward dip from the B-2 site, however. Heavy lines show approximate position of faults and or difficult to interpret.

short-ranging Globorotalia fohsi robusta Indicate the lower part of Zone N.13. At 3,900 ft $(1,189 \mathrm{~m})$ Globorotalia peripheroacuta marks the top of Zone N.12. At 3,960 ft $(1,207 \mathrm{~m})$ the GI. fohsi group disappears, suggesting that Zone N.11 was penetrated at this depth. However, caved specimens of the Gl. fohsi group recur deeper in the we11. At 4,230 ft $(1,289 \mathrm{~m})$, the radiolarian Calocycletta virginis indicates an 0.369 middle Miocene age, as does the radiolarian Calocycletta costata at 4,350 ft $(1,326 \mathrm{~m})$.

At $4,410 \mathrm{ft}(1,344 \mathrm{~m})$, the first appearance of Globigerinoides sicanus marks the top of Zone N.9, the lowest zone of the middle Miocene. Cannartus mammiferus, a lower middle Miocene radiolarian, also occurs for the first time at this level. Turborotalia scitula flrst appears at $4,440 \mathrm{ft}(1,353 \mathrm{~m})$.
Lower Miocene rocks $(\sim 4,470$ to $\sim 4,680 \mathrm{ft}$; $\sim 1,363$ to $\sim 1,427 \mathrm{~m}$ )

At 4,470 ft $(1,363 \mathrm{~m})$, lower Miocene radiolarians appear: Stichocorys wolffii and Cannartus violina at 4,470 ft, and Cannartus tubarius at $4,500 \mathrm{ft}(1,372 \mathrm{~m})$. The sample at 4,500 ft also contains the diagnostic planktic foraminifer Turborotalia kugleri, which ranges no higher than Zone N.4, the lowest Miocene zone. At $4,530 \mathrm{ft}(1,381 \mathrm{~m})$, the lower Miocene radiolarian Cannartus prismaticus is present, and at 4,590 ft $(1,399 \mathrm{~m})$, Globigerina auguliofficinalis, $G$. augulisuturalis, $G$. pseudociperoensis, and $G$. ouachitaensis appear together. The thinness of the interval between the top of N.9 and the highest lower Miocene rocks (probably Zone N.5) and the absence of any 
suggestion of Zones N.8 through N.6 in these deepwater sediments are evidence of a possible disconformity separating lower middle Miocene and lower Miocene rocks at approximately 4,450 ft $(1,356 \mathrm{~m})$.

$$
\begin{gathered}
\text { Upper 01igocene rocks }(\sim 4,680 \text { to } \sim 4,980 \mathrm{ft} ; \\
\sim 1,427 \text { to } \sim 1,518 \mathrm{~m})
\end{gathered}
$$

The upper boundary of the oligocene is not well defined by planktic foraminifers, as pointed out by many authors. (See Hardenbol and Berggren, 1978, for current status of the boundary.) Most authors place it elther at the base of, or somewhere within, Zone N.4; but its exact placement has not been firmly established. It is widely agreed, however, that Globigerina opima forma nana does not range above the upper 01igocene Zone P.22 (in fact, it may not quite reach the upper boundary), and the first occurrence of this species is used to identify the youngest oligocene rocks, at 4,680 ft $(1,427 \mathrm{~m})$. The transition from the lower Miocene $T$. kugleri assemblage seems to take place without any break in sedimentation. At $4,740 \mathrm{ft}(1,445 \mathrm{~m})$, Globigerina opima forma typica marks the top of Zone P.21. At 4,830 ft $(1,472 \mathrm{~m})$ the typical late oligocene radiolarians Dorcadospyris ateuchus and Theocyrtis annosa appear. Zone P.20 may be present between 4,770 and $4,980 \mathrm{ft}(1,454$ to $1,518 \mathrm{~m}$ ), but the absence of diagnostic species of lower 01Igocene Zones $\mathrm{N} .19$ and N.18 above the highest Eocene rocks suggests that a disconformity separates the upper 01igocene and upper Eocene at $\sim 4,980 \mathrm{ft}(1,518 \mathrm{~m})$.

$$
\begin{gathered}
\text { Eocene rocks }(\sim 4,980 \text { to } \sim 6,030 \mathrm{ft} ; \\
\sim 1,518 \text { to } \sim 1,838 \mathrm{~m})
\end{gathered}
$$

A few upper Eocene foraminifers were encountered at 4,590 ft $(1,509 \mathrm{~m}$ ) (Turborotalia cocoaensis and $T$. cerroazulensis), but are considered to have been redeposited in the 0ligocene. At $4,980 \mathrm{ft}(1,518 \mathrm{~m})$, the first in situ Eocene planktic assemblage appears and contains Globigerinatheka mexicana and Gk. semiinvoluta, which mark the lower part of Zone P.15. Thus, the uppermost Eocene as well as the lowermost oligocene is missing at the disconformable Eocene-0ligocene contact.

At $5,190 \mathrm{ft}(1,582 \mathrm{~m})$, the first indication of middle Eocene rocks appears. Here, Morozovella spinulosa, Tmuncorotaloides rohri, and $T$. topilensis mark the top of Zone P.14. At 5,220 ft $(1,591 \mathrm{~m})$ Acarinina bullbrooki marks the top of Zone P.13, and at $5,310 \mathrm{ft}(1,619 \mathrm{~m})$ Subbotina frontosa marks the top of Zone P.12. At 5,730 ft $(1,637 \mathrm{~m})$, a sulte composed of Acarinina pentacamerata, $A$. broedermanni, Subbotina inaequispira, S. higginsi, and Morozovella aragonensis marks the top of Zone P.11. Zone P.10 may be present above 5,490 ft $(1,673 \mathrm{~m})$ but was not recognized.
At $5,490 \mathrm{ft}(1,673 \mathrm{~m})$, the youngest lower Eocene rocks of Zone P.9 contain Morozovella caucasica. Acarinina soldadoensis formas typica and augulosa appear at 5,550 ft $(1,692 \mathrm{~m})$. An interval of conspicuous redeposition of Paleocene planktic foraminifers occurs between 5,840 and $5,890 \mathrm{ft}(1,780$ and $1,795 \mathrm{~m})$, where Acarinina praecursoria, $A$. trinidatensis, and Planorotalites compressa appear. (A. praecursoria was also noted in the sidewall core at $5,840 \mathrm{ft}(1,780 \mathrm{~m})$.) However, sidewall cores and cuttings below this interval contain a progressively older suite of lower Eocene assemblages. Zone $P .8$ is marked at $5,840 \mathrm{ft}$ $(1,780 \mathrm{~m})$ by Morozovelza formosa, at $5,920 \mathrm{ft}$ $(1,804 \mathrm{~m})$ by $M$. subbotinae, and at $5,960 \mathrm{ft}$ $(1,817 \mathrm{~m})$ by $M$. gracilis.

At $5,990 \mathrm{ft}(1,826 \mathrm{~m})$ in both cuttings and a sidewall core, the middle of zone $P .7$ is Indicated by the appearance of Morozovella marginodentata. Zone P.6 is marked at $6,020 \mathrm{ft}$ $(1,835 \mathrm{~m})$ by the appearance of Subbotina velascoensis, Morozovella velascsensis, $M$. acuta, and $M$. simulatilis. A few redeposited specimens of Cretaceous globotruncanids also are present at $6,020 \mathrm{ft}$.

\section{Paleocene rocks}

In situ foraminffers of Paleocene age have not been recognized in the CoST NC. B-3 we11. This is in accord with the record of calcareous nannofossils and palynomorphs (Valentine, this volume; Steinkraus, 1979). However, the presence of scattered Paleocene specimens (Acarinina praecursoria, A. trinidadensis, Planorotalites compressa, Morozovella kolchidica, and $M$. pusilla forma typica) in the interval from $5,840 \mathrm{ft}(1,780 \mathrm{~m})$ to $6,020 \mathrm{ft}$ $(1,835 \mathrm{~m})$ is evidence that upper Paleocene rocks were originally deposited in the vicinity of the well site and have since been eroded. Paleocene rocks are also missing from the COST No. B-2 we11 (fig. 24).

$$
\begin{gathered}
\text { Maestrichtian rocks }(\sim 6,030 \mathrm{ft} \text { to } \sim 6,110 \mathrm{ft} ; \\
\sim 1,838 \text { to } \sim 1,862 \mathrm{~m})
\end{gathered}
$$

The youngest Cretaceous rocks in the COST No. B-3 we11 occur at $6,030 \mathrm{ft}(1,838 \mathrm{~m})$ and contain a diverse planktic assemblage, including Globotruncana contusa, Gt. rosetta, Gt. elevata, Gt. arca, Gt. aff. stuartiformis, Gt. stephensoni, Gt. patelliformis, Rugoglobigerina migosa, $R g$. hexacamerata, and Ventilabrella multicamerata. This assemblage, in conjunction with Gt. gansseri at $6,040 \mathrm{ft}(1,841 \mathrm{~m}$; Steinkraus, 1979), is indicative of Zones UC 13 and 14 of the lower Maestrichtian. The benthic foraminiferal assemblage does not undergo as drastic a change from the lower Eonene as the planktic assemblage does, but the appearance of the benthic species Globorotalites michelinianus and Brizalina incrassata confirms the Late Cretaceous age at $6,030 \mathrm{ft}(1,838 \mathrm{~m})$. 


\section{Campanian rocks $(\sim 6,110$ to $\sim 6,420 \mathrm{ft}$; $\sim 1,862$ to $\sim 1,957 \mathrm{~m})$}

The top of the Campanian Zone UC 12 is recognized at $6,110 \mathrm{ft}(1,862 \mathrm{~m})$ by the highest occurrence of Globotruncana ventricosa and Neoflabellina migosa. A major increase in the abundance and diversity of benthic species accompanies this planktic datum. At 6,240 ft $(1,902 \mathrm{~m})$, Gt. calcarata in a sidewall core and Bolivinoides decoratus in the cuttings mark the top of Zone UC 10. The first Epistomina supracretacea appears at $6,380 \mathrm{ft}(1,945 \mathrm{~m})$.

$$
\begin{gathered}
\text { Santonian rocks }(\sim 6,420 \text { to } \sim 7,040 \mathrm{ft} ; \\
\sim 1,957 \text { to } 2,146 \mathrm{~m})
\end{gathered}
$$

Santonian rocks are marked by the appearance of Bolivinoides strigillatus at 6,429 ft $(1,957 \mathrm{~m})$. It is accompanied by a few specimens of Marginotruncana angusticarenata. Marginotruncana renzi appears at $6,510 \mathrm{ft}(1,984$ m). At 6,526 ft $(1,989 \mathrm{~m})$ Marginotruncana concavata, found in a sidewall core, marks the top of Zone UC 8. Globorotalites multiseptus is frequent at $6,580 \mathrm{ft}(2,006 \mathrm{~m})$; and the first frequent occurrence of Epistomina supracretacea is at $6,680 \mathrm{ft}(2,036 \mathrm{~m})$. At $6,860 \mathrm{ft}(2,091$ m), Marginotmuncana pseudolinneiana becomes conspicuous and the first $M t$. concavata along with Archaeoglobigerina bosquensis, occurs in the cuttings.

$$
\begin{gathered}
\text { Confactan rocks }(\sim 7,040 \text { to } \sim 7,900 \mathrm{ft} ; \\
\sim 2,146 \text { to } 2,408 \mathrm{~m})
\end{gathered}
$$

The top of the Confacian section is tentatively placed at $7,040 \mathrm{ft}(2,146 \mathrm{~m})$ on the basis of the appearance of Marginotruncana marginata and Whiteinella archaeocretacea. The Coniaclan top may be somewhat deeper in the we11, however, because elsewhere both Mt. marginata and $W t$. archaeocretacea are known to range up into the lower Santonian. Epistomina stelligera forma typica, which is apparently restricted to the Conlacian and Turonian of the Scotian Basin (Ascoll, 1976), appears in moderate abundance at $7,130 \mathrm{ft}(2,173 \mathrm{~m})$. Steinkraus (1979) reported Globotmuncana sigali and Gt. schneegansi in cuttings at $7,110 \mathrm{ft}$ $(2,167 \mathrm{~m})$, but I did not observe Gt. schneegansi in cuttings higher than $7,380 \mathrm{ft}(2,249 \mathrm{~m})$. It occurred in the sidewall core at $7,490 \mathrm{ft}(2,283$ m), along with Hedbergella amabilis.

Turonfan rocks $(\sim 7,900$ to $\sim 8,260 \mathrm{ft}$; $\sim 2,408$ to $\sim 2,518 \mathrm{~m}$ )

The 1ithologic, paleoenvironmenta1, and faunal changes across the Coniacian-Turonian transition suggest that a disconformity separates these stages. The first Turonian assemblage occurs at $7,900 \mathrm{ft}(2,408 \mathrm{~m})$ and contains Praeglobotruncana stephani, which marks the top of Zone UC 4 of the lower Turonian; it is accompanied by Gavelinopsis tourainensis.
Just above this level, a fine-grained sendstone from 7,610 to 7,810 ft $(2,320$ to $2,381 \mathrm{~m})$ contains sparse inner shelf faunas with scattered glauconite grains, coal, and gypsum (Lachance, 1979; this paper, fig. 27). Thus, the middle and upper Turonian and perhaps part of the lower Confacian appear to be missing from the COST No. B-3 we11.

At 7,990 ft $(2,435 \mathrm{~m})$, Gavelinopsis tourainensis has a more strongly inflated umbo than in higher samples. At $8,080 \mathrm{ft}(2,463 \mathrm{~m})$ and 8,170 ft $(2,490 \mathrm{~m}), P g$. stephani is more abundant and develops a more varied morphology. Lingulogavelinella turonica appears at $8,170 \mathrm{ft}(2,490 \mathrm{~m})$.

$$
\text { Cenomanian rocks }(\sim 8,260 \text { to } \sim 9,170 \mathrm{ft} \text {; }
$$$$
\sim 2,518 \text { to } 2,795 \mathrm{~m} \text { ) }
$$

The first rotaliporids marking the Cenomanian (Zone UC 3) appear at $8,260 \mathrm{ft}(2,518$ m). At this level, Rotalipora cushmxni, $R$. greenhormensis, and $R$. reicheli occur together, an association which suggests that the uppermost Cenomanian rocks are missing. Gavelinopsis cenomanica and Gavelinella baltica alsc appear at $8,260 \mathrm{ft}$. At $8,490 \mathrm{ft}(2,588 \mathrm{~m})$, the appearance of Favuselia washitensis marks the top of the lower Cenomanian Zone UC 2.

$$
\begin{gathered}
\text { Albian rocks }(\sim 9,170(?) \text { to } \sim 9,530 \mathrm{ft} ; \\
\sim 2,795 \text { to } \sim 2,905 \mathrm{~m})
\end{gathered}
$$

The first diagnostic foraminifer of Albian age, Favuselza cf. F. scitula, appears at 9,170 ft $(2,795 \mathrm{~m})$ and indicates Zone LC 19 ("Ichael, 1972). This level is $500 \mathrm{ft}(152 \mathrm{~m})$ below the top of the Albian as recognized on the basis of palynomorphs (Steinkraus, 1979). T/is low position of the first Albian foraminifer: may be the result of environmental exclusion from the higher beds. The interval from 8,710 to 9,170 ft $(2,655$ to $2,795 \mathrm{~m})$ consists chlefly of gray, slightly sandy shale and mudstone with thin coal laminae, sandstone beds, and limestone nodules in places (Lachance, 1979). The foraminiferal fauna is very sparse, terrestrial palynomorphs are abundant, and inner shelf to marginal-marine paleoenvironments are postulated for the interval.

At $9,350 \mathrm{ft}(2,850 \mathrm{~m})$ the first assemblage of abundant Epistomina spinulifera form? colomi appears, and at 9,410 ft $(2,868 \mathrm{~m})$ Favusella nitida and $F$. pessagnoi appear as rare specimens.

$$
\begin{gathered}
\text { Aptian rocks }(\sim 9,530 \text { to } \sim 10,070 \mathrm{ft} ; \\
\sim 2,905 \text { to } \sim 3,069 \mathrm{~m})
\end{gathered}
$$

The top of the Aptian Stage is placed at $9,530 \mathrm{ft}(2,905 \mathrm{~m})$ on the basis of palynomorphs (Steinkraus, 1979). The forminiferal evidence for Aptian rocks is not strong, but the benthic species Gavelinella barremiana, which ranges no higher than the Aptian in the Scotian Basin (Asco11, 1976), first appears at 9,530 ft. The 
remaining Aptian interval contains sparse foraminiferal and nannofossil assemblages owing to the shallow-water paleoenvironment.

Barremian rocks $(\sim 10,070$ to $\sim 10,500 \mathrm{ft}$; $\sim 3,069$ to 3,201 m)

Barremian rocks were first recognized at $10,070 \mathrm{ft}(3,069 \mathrm{~m})$ on the basts of palynomorphs (Steinkraus, 1979), but no significant change was observed in the sparse foraminiferal assemblages near this level. The lower part of the Barremian interval is especially sparse in foraminiferal remains, and the thick-bedded, coaly sandstones in this interval appear to be of nonmarine origin.

Hauterivian rocks $(\sim 10,500$ to $\sim 10,770 \mathrm{ft}$; $\sim 3,201$ to $\sim 3,283 \mathrm{~m}$ )

Hauterivian rocks were recognized on the basis of palynomorphs within a shaley limestone at $10,610 \mathrm{ft}(3,234 \mathrm{~m})$ (Steinkraus, 1979). The foraminiferal faunas are very sparse, probably because the limestone is indurated, but they presumably were deposited in a shallow-marine paleoenvironment. A disconformity may separate the nonmarine Barremian sandstone and the Hauterivian limestone, and the top of the Hauterivian is placed at this contact.

$$
\begin{gathered}
\text { Valanginian rocks }(\sim 10,770 \text { to } \sim 11,920 \mathrm{ft} ; \\
\sim 3,283 \text { to } \sim 3,633 \text { m) }
\end{gathered}
$$

A rich assemblage of agglutinated benthic forminffers appears abruptly below the Hauterivian limestone at $10,770 \mathrm{ft}(3,283 \mathrm{~m})$. Prominent constituents are Everticyclammina virguliana and Haplophragmium sp. In the Scotian Basin, $E$. virguliana (=Buccicrenata italica of Ascoli, 1976) does not range above the Valanginian, and on this basis, the top of the Valanginian section is placed at $10,770 \mathrm{ft}$ $(3,283 \mathrm{~m})$.

$$
\begin{gathered}
\text { Berriasian rocks }(\sim 11,920 \text { to } \sim 12,260 \mathrm{ft} ; \\
\sim 3,633 \text { to } \sim 3,737 \mathrm{~m})
\end{gathered}
$$

The top of the Berriasian stage is placed at $11,920 \mathrm{ft}(3,633 \mathrm{~m})$ on the basis of palynomorphs (Steinkraus, 1979). The benthic foraminiferal assemblage is moderately well developed, but no dlagnostic species were recognized. This lack of foraminiferal definition extends to the Scotian Basin, where Ascoli (1976) also was unable to separate Berriasian and Valanginian foraminiferal assemblages.

$$
\begin{gathered}
\text { Tithonian rocks }(\sim 12,260 \text { to } \sim 13,390 \mathrm{ft} ; \\
\sim 3,737 \text { to } 4,081 \mathrm{~m})
\end{gathered}
$$

The highest occurrence of Jurassic foraminifers, representing the Tithonian Stage $1 s$ at $12,260 \mathrm{ft}(3,737 \mathrm{~m})$, where Fpistomina dneprica appears. This is one of the species that Ascoli (1976) used to recognize Tithonian rocks in the Scotian Basin. At $12,500 \mathrm{ft}(3,810$ $\mathrm{m})$ in the rotary cuttings, and at $12,510 \mathrm{ft}$ $(3,813 \mathrm{~m})$ in a sidewall core, two more of Ascol1's (1976) Upper Jurassic markers appear: Epistomina uhligi, in abundance, and a few $E$. mosquensis. The placement of tl : TithonianBerriasian boundary is perhaps the most controversial boundary problem in the Baltimore Canyon trough and Scotian Basin (Ascoll, 1976; Steinkraus, 1979, Valentine, this volume). Based on this study, the placenent of the boundary in the B-3 well is approximately the same as that of Steinkraus (1979), who placed it at $12,400 \mathrm{ft}(3,780 \mathrm{~m})$ on tre basis of palynomorphs and calcareous nannofossils. However, Valentine's interpretation of the calcareous nannofossil assemblages (Valentine, this volume) places the top of the Tithonian approximately $1,200 \mathrm{ft}(366 \mathrm{~m})$ 1ower than the foraminifers indicate.

The major reasons for using the scotian Basin boundary events are the larre number of wells (more than 20) analyzed by Ascoli and his colleagues and the intercorrelation of foraminifera1, palynomorph, and calpionellid datums in the Scotian Basin and Grand Banks (Ascoli, 1976, and personal communication, 1978; Gradstein and others, 1975). The calpionellids are shortranging planktic organisms (restricted to the oldest Cretaceous and youngest Jurassic rocks) and appear to offer the best possibility for accurate correlation with the Tithonian Stage in Europe.

The $\operatorname{cosT}$ No. B-3 well Tithorian foraminiferal datum has also been recognized in the COST No. B-2 we11, and the original placement of the boundary in the $\mathrm{B}-2$ well has been raised from below $16,043 \mathrm{ft}(4,848 \mathrm{~m}$; Scholle, 1977) to $11,830 \mathrm{ft}(3,606 \mathrm{~m}$; Poag, 1979). This agrees with a re-vision of cosT No. B-2 well palynomorph interpretations carried out by Bebout (J. Bebout, written communication, 1978; Amato and Simonis, 1979, p1. 2).

Kimmeridgian rocks $(\sim 13,390$ to $\sim 15,390(?)$ ft; $\sim 4,081$ to $\sim 4,691(?) \mathrm{m})$

The first foraminiferal evidence of Kimmeridglan rocks is the presence of Kumubia palestinensis at $13,390 \mathrm{ft}(4,081 \mathrm{~m})$ (Ascoli, 1976). This is $170 \mathrm{ft}(52 \mathrm{~m})$ below the highest Kimmeridgian palynomorphs (Steinkraus, 1979). At $14,000 \mathrm{ft}(4,267 \mathrm{~m})$, Alveosepta jaccardi, an agglutinated benthic foraminifer, marks the approximate top of the lower Kimmeridgian (Ascol1, 1976). At 14,320 ft $(4,365 \mathrm{~m})$, Epistomina stellicostata, E. madagxscariensis, and Eoguttulina liassica are present.

$$
\begin{gathered}
\text { Callovian(?) rocks }(\sim 15,390 \text { to } \sim 15,820 \mathrm{ft} ; \\
\sim 4,691 \text { to } \sim 4,822 \mathrm{~m})
\end{gathered}
$$

No specimens older than Kimmeridgian In age 
were found among the palynomorphs (Steinkraus, 1979) or calcareous nannofossils (Valentine, this volume) in the $\operatorname{cosT}$ No. $B-3$ well, but at 15,390 ft $(4,691 \mathrm{~m})$, the benthic foraminifer Epistomina coronata may Indicate that Callovian rocks were penetrated. This species and Garantella ornata, which appears at $15,420 \mathrm{ft}$ $(4,700 \mathrm{~m})$, range no higher than the Callovian Stage in the Scotian Basin (Ascoli, 1976).

\section{PALEOENVIRONMENTS}

\section{Data and Interpretations}

The discussion of paleoenvironments, in contrast to that of the biostratigraphy, follows the chronology of deposition from the bottom of the well to the top. This treatment is based primarily on foraminiferal assemblages, but it also incorporates other faunal and floral elements as well as the lithology (Amato and Simonis, 1979), especially in considering the Jurassic and Lower Cretaceous rocks. A paleobathymetric curve for the $B-3$ well accompanies figure 23; it can be compared to that for the B-2 well in figure 24. A paleoenvironmental cross section is illustrated in figure 26. (See Steinkraus, 1979; Bebout and Lachance, 1979; and Valentine, this volume, for alternative interpretations.)

The reader is reminded that the water depths given herein are gross estimates, and their imprecision increases in proportion to the age of the faunas and floras. This is especially true for the Mesozolc assemblages because all of the species and most of the genera are extinct. Furthermore, the seismic profiles show that terms like "inner shelf" and "upper slope" probably lacked today's physlographic meaning at the time of deposition of some of the rock units in the Baltimore Canyon trough (for example, during the Eocene). Nevertheless, the depth estimates are useful in conveying the relative changes in water depth through time, and they provide a point of departure for future studies of the depositional cycles of this basin.

The oldest rocks in the COST No. B-3 we 11 (Callovian(?) through early Kimmeridgian; 15,820 to $14,500 \mathrm{ft} ; 4,823$ to $4,421 \mathrm{~m})$ contain very sparse, scattered foraminiferal assemblages of low species diversity. Epistominids and Foguttulina are the predominant forms. The lithic components are interlaminated gray shale, gray oolitic limestone, and thin, light-gray to white sandstone beds interbedded with several thin coal beds (fig. 27). The sandy, coaly beds may represent alternating shallow-marine and coastal-marsh deposits (fig. 26), but the limestones appear to be shallow-marine "backreef" deposits associated with the carbonate platform that formed the Late Jurassic shelf edge about $6 \mathrm{mi}(10 \mathrm{~km})$ seaward (eastward) of the $\operatorname{cosT}$ No. B-3 well site (fig 26; Schlee and
Grow, this volume). The low percentege of terrestrial palynomorphs in this section (Bebout and Lachance, 1979) suggests that during most of the deposition, the continental shorelire was not near the well site in spite of the shallowwater conditions. However, the shoreline must have lain between the $\mathrm{B}-3$ and $\mathrm{B}-2$ we11 sites. The B-2 is profected about $22 \mathrm{mi}(35 \mathrm{~km})$ up depositional dip from $\mathrm{B}-3$, and nonmarine shales and sandstones inter-bedded with coal beds accumulated at B-2 during this time interval (fig. 26).

During deposition of the rest of the lower and upper Kimmeridgian and lowest Tithonian rocks $(14,500$ to $13,100 \mathrm{ft} ; 4,421$ to $3,934 \mathrm{~m})$, slightly deeper water depths generally preralled at the B-3 well site. Epistominids are frequent, and Trocholina and Lenticulina are common. Alveosepta and Everticyclammina occur sporadically, but are abundant at $14,020 \mathrm{ft}$ $(4,274 \mathrm{~m})$ and 13,160 ft $(4,012 \mathrm{~m})$ respectively. The percentage of terrestrial palynomorphs did not change appreciably, b't the amount of limestone increased and coal befs are absent. Water depths probably did not exceed $160 \mathrm{ft}$ (50 m).

The zone of foraminiferal sparsity botween 13,100 and $12,700 \mathrm{ft}(3,994$ to $3,872 \mathrm{~m})$ probably resulted from the induration of the limertone, but "middle- shelf" assemblages return across the Tithonian-Berriasian boundary $(12,7) 0$ to $11,900 \mathrm{ft} ; 3,872$ to $3,628 \mathrm{~m}$ ) as sandstone and shale become the predominant 11thofacles. Epistominids predominate and accompany Ophthalmidium, Trocholina, Tristix, Lentic.lina, and often abundant Marssonella.

Most of the interbedded sandstone, shale, limestone, and siltstone of the Valanrinian Stage (fig. 27) encloses a sparse banthic foraminiferal assemblage, mainly epistoninids and lenticulinids, that indicates marginal marine conditions. However, at the top of the Valanginian, a rich assemblage of agglutinated benthic foraminifers (Everticyclamina, Haplophragmium), along with a few epistoninids and spirillinids, accompanies a significant decrease in terrestrial palynomorphs (Bebort and Lachance, 1979). This is interpreted as a transgressive marine pulse that produced water depths of about $160 \mathrm{ft}(50 \mathrm{~m})$ at the COST No. B3 well site (figs. 23 and 26 ).

Just above the uppermost Valanginian, a 250-ft (76-m) interval of Hauterivian shaley limestone (fig. 27) yielded essentially no calcareous marine microfossils, probably bacause it is indurated, but it undoubtedly represents shallow-marine paleoenvironments. The 100-ft $(30-\mathrm{m})-$ thick Barremian sandstone overlying the Hauterivian limestone ( $f 1 g .27$ ) is barren of microfossils and is thus interpreted as to having been deposited in nonmarine conditions; as a result, a disconformity is recognized at the Barremian-Hauterivian contact. 


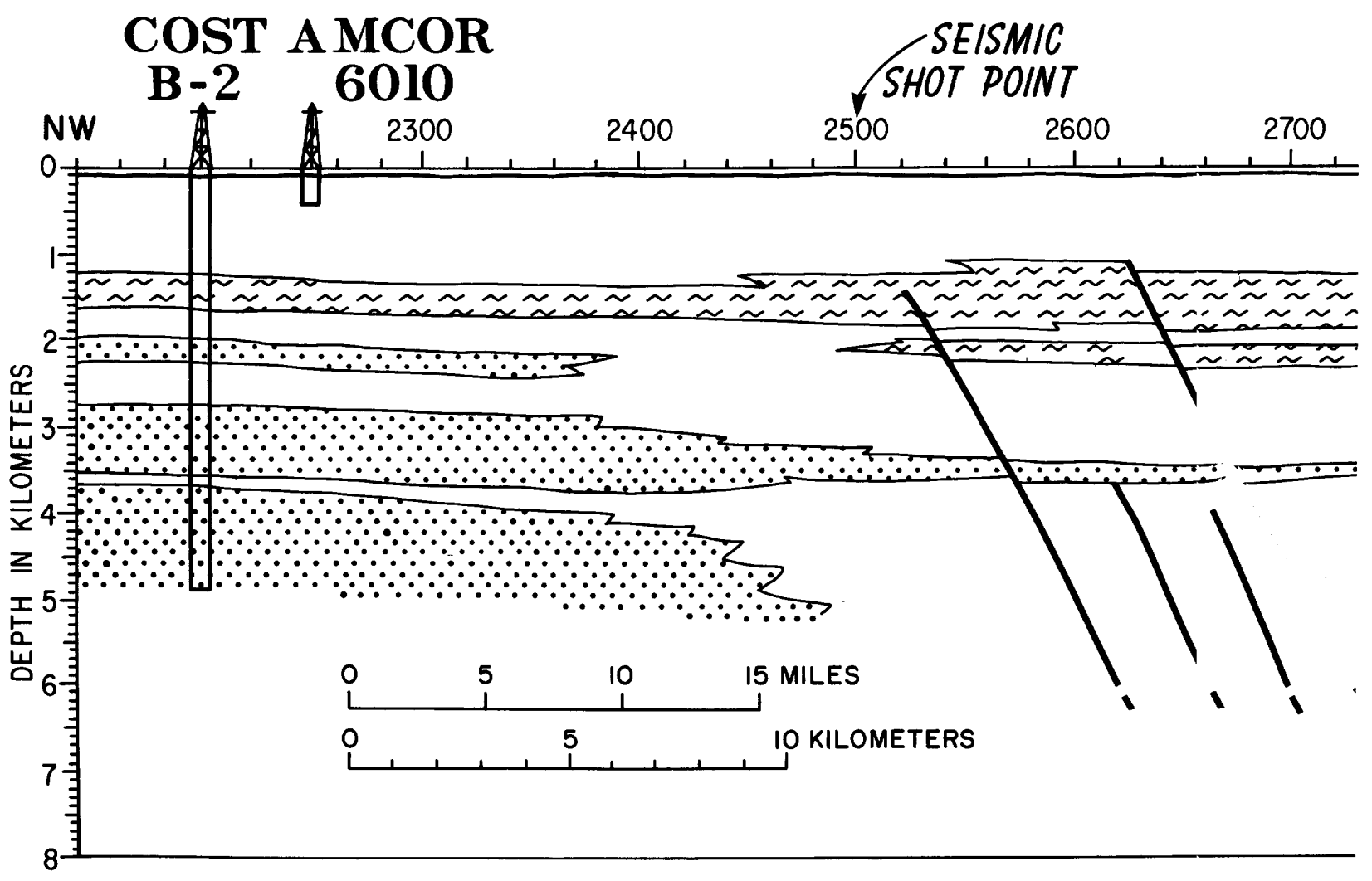

Figure 26.--Paleoenvironmental cross section along USGS Seismic Line 25. (See figs. 22 and 25. ) Heavy lines show approximate position of faults and outline of carbonate platform

The remaining Barremian and the Aptian rocks $(10,350$ to $9,550 \mathrm{ft} ; 3,155$ to $2,911 \mathrm{~m})$ are Interbedded, 1ight-gray sandstones, dark-gray to black shales, soft white limestones, and thin siltstones ( $f 1 g, 27)$. The foraminifers in this Interval are scattered small assemblages of eplstominids, lenticulinids, and gavelinellids, plus frequent microgastropods. The percentage of terrestrial palynomorphs is quadruple that of the lower Barremian and Hauterivian. These rocks are interpreted as having accumulated in shallow-marine conditions of not greater than 65-ft (20-m) depth.

Similar faunas persist up to $8,550 \mathrm{ft}$ $(2,606 \mathrm{~m})$ in Cenomanian rocks consisting chiefly of 11ght-gray to brown shale and white sandstone (f1g. 27), and a similar shallow-marine paleoenvironment is inferred. A significant exception occurs between 9,550 and 9,300 ft $(2,910$ to $2,835 \mathrm{~m})$, where an assemblage of abundant Epistomina spinulifera, gavellnellids, and a few favusellids appears in the lower part of a zone of limestone nodules. The decrease in terrigenous lithic components, the more abundant foraminifers, and the inclusion of planktic specles (favusellids) suggest that slightly

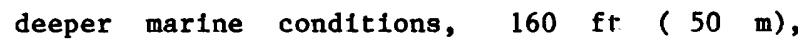
prevailed during deposition of this interval.

From 8,550 to $\sim 8,230(2,606$ to $\sim 2,509 \mathrm{~m})$, Cenomanian foramintferal assemblares become increasingly richer in specimens and species, and planktic forms gradually bscome more frequent as the 1ithology changes from fine sandstone to shale (fig. 27). The foramintferal assemblage is richest at the tCD of this interval $(8,260 \mathrm{ft} ; 2,518 \mathrm{~m})$, where it consists of abundant gavellineliids, 1ingulogavelinellids, gavelinopsids, and lenticulinids as well as frequent rotaliporids and praeglobotruncanids. "Middle-shelf" conditions that include a water depth of about $270 \mathrm{ft}$ (80 m) may be inferred for this interval.

Above a disconformity that separates Cenomanian and Turonian ronks (see "Biostratigraphy" section), shallcw "middleshelf" conditions accompanied deposition of gray Turonian shale $(8,230$ to $7,850 \mathrm{ft} ; 2,509$ to $2,393 \mathrm{~m}$; fig. 27). These foraminiferal assemblages are not as rich as those at the top of the Cenomanian, but they are similar in generic composition. Among the planltic genera, the Cenomanian rotaliporids are not present, but Praeglobotruncana is frequent. 


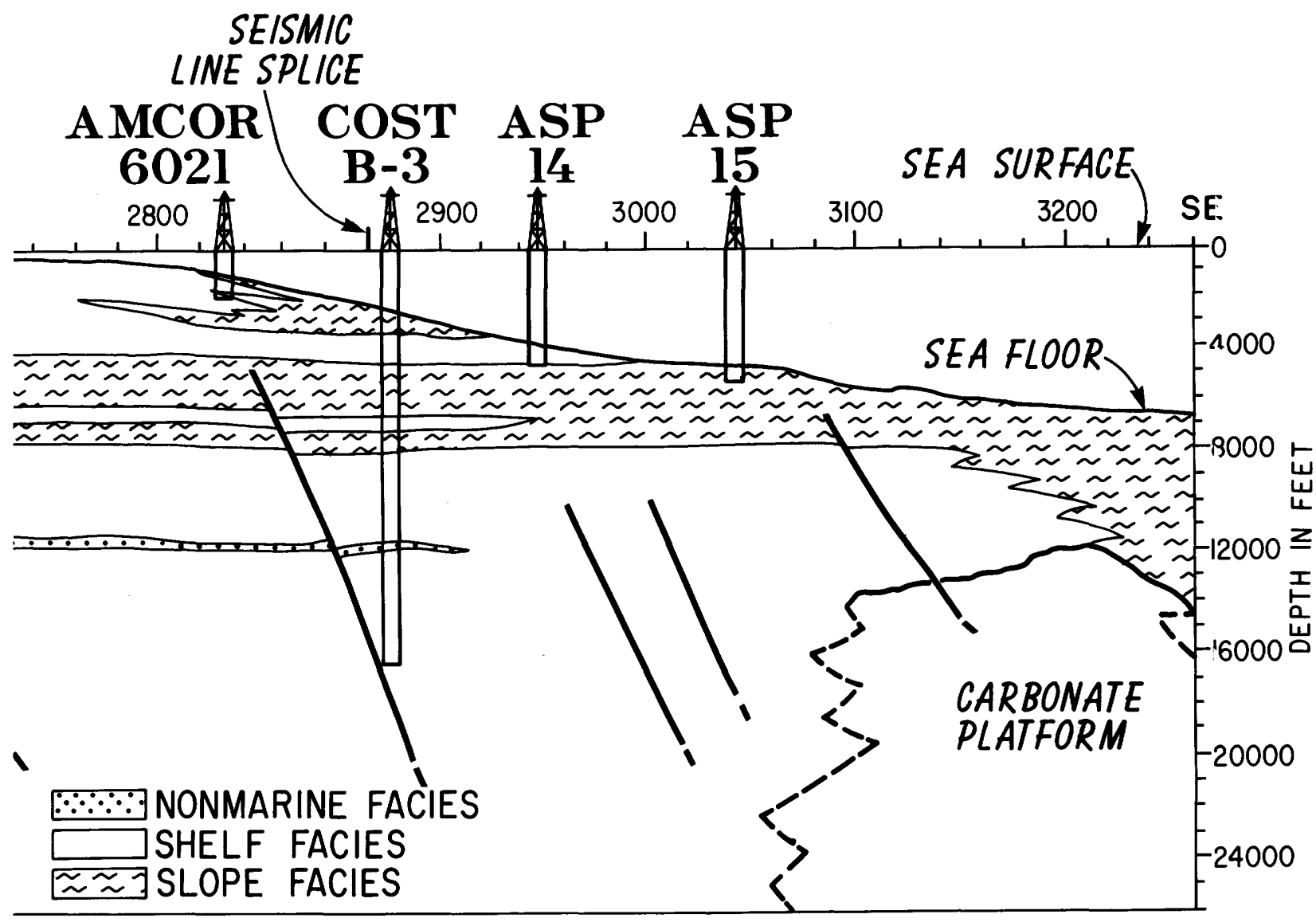

Drill sites have been projected approximately along strike to intersect the seismic profile. section; these lines are dashed where data is sparce or difficult to interpret.

Above the Turonian shale lies a 200-ft (61m)-thick, glauconitic, fine-grained sandstone $(7,810$ to $7,610 \mathrm{ft} ; 2,381$ to $2,320 \mathrm{~m}$; Lachance, 1979) containing sparse, poorly preserved foraminifers and scattered gypsum crystals. This striking change in 1ithology and fauna, in conjunction with the lack of evidence for upper and middle Turonian rocks (see "Biostratigraphy" section), leads to the inference that a disconformity separates the lower Turonian and the Coniacian, and this fits the interpretation of seismic stratigraphy along USGS Seismic LIne 25 (Schlee and Grow, this volume). On the other hand, one could argue that the sparsely fossiliferous sandstone may represent part of the upper and middle Turonian.

From 7,710 to $6,110 \mathrm{ft}(2,350$ to $1,862 \mathrm{~m})$, the Coniacian through Campanian foraminiferal faunas become increasingly rich and diverse, culminating in "upper-slope" assemblages $(1,000$ to $1,300 \mathrm{ft}$ water depth; 300 to $400 \mathrm{~m}$ ) between 6,700 and 6,100 ft $(2,042$ and $1,859 \mathrm{~m}$; fig. 23). The dominant lithology throughout this interval is interbedded 1ight- to medium-gray mudstone and shale (fig. 27; Lachance, 1979). The Coniacian foraminferal assemblages contain epistominids, ammobaculitids, karreriellids, bolivinopsids,

spiroplectaminids, gavelinellids, lenticulinids, and a sparse planktic association. In the lower Santonian, planktic specimens are more abundant; Bolivinita, Loxostomum, Eouvigerina, Gyrjidina, and a few bathysiphons appear.

In the upper Santonian and Campanian rocks, very rich and diverse assemblages of both planktic and benthic foraminifers are present. Benthic forms include Pseudotextilaria, Bolivinoides, Heterostomella, Donothia, Gaudryina, Textularia, Anomalinoides, Bri,alina, Arenobulimina, Stensioina, Neoflabsllina, Kyphopyxa, Clavulinoides, Marginulina, Epistomina, Bathysiphon, Osangilaria, Cribrostomoides, Globorotalites, and Siphouvigerina. (See "Biostratigraphy" section for planktic species.)

The uppermost Campanian and lower Maestrichtian rocks are brownish-gray calcareous mudstones (fig. 27) that contain a somewhat diminished fauna. The planktic assemblage is still rich, but the benthic abundance and diversity are reduced. Globorotalites, Brizalina, Gavelinella, Neoflatellina, Karreriella, Pseudogaudryinella, Ramulina, 


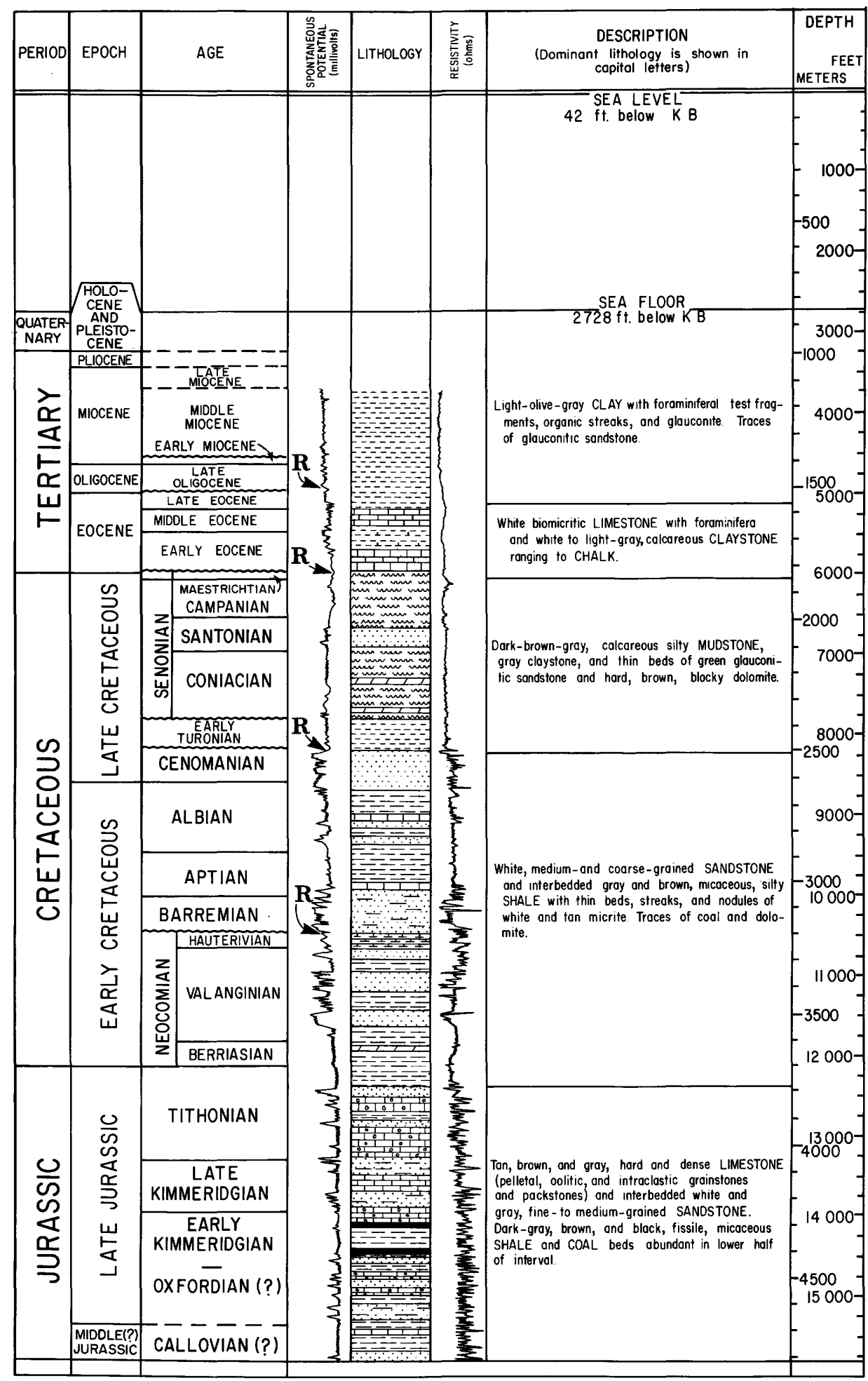

Figure 27.--Lithologic column for the COST No. B-3 well showing lithologic symbols, short lithologic description, foraminiferal biostratigraphy, and geophysical-log characteristics. " $R$ " next to spontaneous-potential curve indicates lcsation of lithologic contacts that are easily recognized as strong reflectors on USias Seismic Line 25. Lithologies modified from Amato and Simonis (1979, p1. 2). 
Bulimina, Osangularia, and Cribrostomoides are typical benthic constituents. This is interpreted to be an "outer-shelf" assemblage of about a 500- to 650-ft (150- to 200-m) water depth.

The change in benthic foraminifers across the lower Eocene-lower Maestrichtian contact is not dramatic, although the planktic assemblage changes significantly. The lithologic change also is a significant one in which the brownishgray mudstone changes upward to white blomicritic limestone (f1g. 27; Adinolft and Jacobson, 1979). The absence of the Paleocene Series here and at the COST No. B-2 well site (figs. 23 and 24) is evidence of a major, widespread disconformity (see "Biostratigraphy" section).

Benthic species in the lower Eocene interval from 6,030 to $5,900 \mathrm{ft}(1,838$ to 1,798 m) Include members of Tritaxia, Lenticulina, Vaginulinopsis, Bulimina, Cibicides, Gonatosphaera, Cribrostomoides, Marssonella, Pseudogaudryinella, Ellipsoglandulina, Alabamina, and Gavelinella, which suggest an "outer-shelf" paleoenvironment of around a 650-ft (200-m) depth.

From 5,900 to $\sim 5,400$ ft $(1,798$ to $\sim 1,646 \mathrm{~m}$; lower to lower middle Eocene), the benthic assemblages are difficult to interpret. Species representing continental-slope conditions are abundant, but they may be cavings from the overlying "lower-slope" assemblages, as will be explained later. Another association, consisting of "outer-shelf" species, is also present in this section, and is absent or rare above; it includes species of Rosalina, Cibicides, and Nuttallides. These species may represent the in situ assemblage here, but further analysis is required to confirm it. There is also an interval from 5,900 to $5,800 \mathrm{ft}$ $(1,798$ to $1,768 \mathrm{~m})$ in which the benthic forminifers are almost completely absent; this may be due to diagenesis of the chalky white limestones and calcareous claystones that characterize must of the Eocene section (Adinolf1 and Jacobson, 1979, p1. 2; fig. 27). Diagenetic alteration of early Eocene microfossil assemblages seems to be widespread along the Atlantic shelf and slope (Poag and $\mathrm{Ha11}$, 1979).

From $\sim 5,400$ to $5,050 \mathrm{ft}(1,646$ to $1,539 \mathrm{~m})$, the highly calcareous claystones and limestones contain the richest, most diverse benthic assemblages observed in the COST No. B-3 we11. Hoeglundina, Osangularia, large polymorphinids, Gyroidinoides, Gavelinella, Heterolepa, Vulvulina, Lenticulina, Pleurostomella, AlZomorphina, Cyclammina, Karreriella, Dorothia, Marssonella, Tritaxia, Bulimina, and many others, along with an equally rich and diverse planktic assemblage, indicate water depths probably in excess of $3,000 \mathrm{ft}(1,000 \mathrm{~m})$.

At the top of the Eocene section, many of the same species of benthic foraminifers are present in abundance, but some of the deeper water forms, such as Pleurostomella, Allomorphina, and Cyclammina are replaced by somewhat shallower water forms such as costate Uvigerina. This suggests a "lower slope" environment of around a 1,600- to 2,300-ft (500to $700-m)$ depth.

oligocene and most of the early Miocene faunas maintain the "lower slope" aspoct, although the species and lithology change. Light-olive-gray clay and green-gray to browngray calcareous mudstone compose these strata (fig. 27; Lachance, 1979); they contain large polymorphinids, Lenticulina, Uvigerina, Stilostomella, Cibicides, Vulvulina, Tritaxia, Nodosaria, Planulina, Vaginulinotsis, Martinottiella, Siphouvigerina, spinose and costate Uvigerina, Siphogeneria, and Hoeglundina, which suggest water depths of 1,600 to $2,300 \mathrm{ft}(500$ to $700 \mathrm{~m})$. Radiolarians become an important biogenic component of the 0ligccene rocks; and their increasing abundance, elong with that of diatoms, in the oligocene and Miocene strata suggests a surge in primary organic productivity in the photic zone.

At $\sim 4,500$ ft $(\sim 1,372 \mathrm{~m})$ the berthic foraminiferal assemblage changes. The diversity of species diminishes and the large-sized specimens characteristic of the preceding assemblages disappear. Uvigerina mustica is abundant, accompanied by Bulimina, Cibicides, Martinottiella, Nodosaria, and Amphimorplina. This assemblage suggests "upper slope" deptls of $\sim 1,000$ ft $(\sim 300 \mathrm{~m})$; it persists intermittently throughout the lower two-thirds of the middle Miocene strata $(4,500$ to $4,000 \mathrm{ft} ; 1,372$ to $1,219 \mathrm{~m})$, along with increasingly aburdant diatoms and radiolarians.

The simplest explanation for the biogenicsilica enrichment of the clays and mudstones of the Oligocene and Miocene strata (especially the middle Miocene) is the upwelling of nutrientladen bottom water along the shelf edge. At least five factors may be used to infer that upwelling was a significant contributor to this association: (1) Increased ratio of diatoms and radiolarians to foraminifers, (2) presencs of cold-water diatom species, (3) intermittent zones of leached foraminiferal tests, (4) high organic-carbon content in sediments, and (5) high percentage of amorphous (algal) kerogen in the organic carbon.

1. Ratios of diatoms and radiolarians to foraminifers (= opal/calcite) begin to increase significantly in the oligrcene and reach an acme in the middle Mionene. Beneath normally fertile surface waters, bottom waters and interstitial water. are undersaturated with respect to opaline silica, and siliceous skeletons are not preserved (Berger, 1975). Supplies of opal large enough to saturate the bottom and interstitial waters are generated mainly in upwelling regions (DiesterHaass, 1978). The excellent preservation 
of the diatoms and radiolarians in the CosT No. B-3 well is symptomatic of opal saturation or of sedimentation rates high enough to shelter opaline organisms from undersaturated bottom waters.

2. Although the diatom floras of the B-2 and B3 wells have not yet been studied, at updip locations elsewhere on the Atlantic margin, middle Miocene diatom assemblages contain cold-water benthic species (Poag and Hall, 1979; Abbott, in press). Upwelling waters are characteristically as much as $16^{\circ} \mathrm{F}\left(9^{\circ} \mathrm{C}\right)$ colder than surrounding surface waters (Diester-Haass, 1978).

3. Upwelling reglons are sites of poor preservation of calclum carbonate, owing to the enrichment of $\mathrm{CO}_{2}$ in the interstitial water of surface sediments that results from the enormous expansion of biologic productivity (Berger, 1974). Several zones of severely leached benthic foraminiferal tests are present in the middle Miocene strata of the COST No. B-3 we11. The inferred upper slope paleoenvironments normally would be considered to have been shallower than the 1ysocline.

4. Sediments of upwelling regions contain significantly more organic carbon than surrounding regions (Diester-Haas, 1978). The organic-carbon content of the oligocene and Miocene strata is the highest in the CosT No. B-3 well, except for a thin zone of Callovian(?) age at the bottom of the well (Smith, 1979). In the $\operatorname{cosT}$ No. B-2 well, the organic-carbon content of 0ligocene and Miocene rocks is greater than that of any of the other rock units younger than the Valanginian (Claypool and others, 1977).

5. About $50-80$ percent of the kerogen in the oligocene-Miocene strata of the COST No. B-3 well is the amorphous type (algal bodies and amorphous saprope1), indicating that most of the kerogen is of marine origin. In the COST No. B-2 well, amorphous kerogen reaches a maximum of 80 percent in the middle Miocene and diminishes in both younger and older rocks (Claypool and others, 1977). At both we 11 sites, these kerogens are enriched in ${ }^{13} \mathrm{C}$ relative to adjacent strata, a phenomenon that Killingley and Berger (1979) have assoclated with upwelling.

Enrichment in phosphate and fish remains, two additional criteria for identifying sediments assoclated with upwelling (Diester-Haass, 1978), has been noted in Oligocene and Milocene sediments elsewhere along the U.S. Atlantic margin (Gibson, 1976; Hathaway and others, 1979; Poag, unpublished data). Analyses for these characteristics have not yet been carried out in the present area of study.

Another aspect of middle Mlocene deposition that also probably influenced the development of silica-rich plankton communitles wis an increase in terrestrially derived nutrients. As discussed by Poag $(1977,1978)$ and Schlee and Grow (this volume), the middle Mionene strata at B-2 and B-3 are parts of a prograding series of clinoform deltalc beds. At B-2, the inferred high nutrient content of Miocene shelf waters is reflected not only by the rich diatom flora, but by the benthic foraminiferal assembage as we11 (Poag, 1977; Seiglie, 1968). The rapid deposition of terrestrially derived organic-rich sediments (note the high sediment accumulation rates of the middle Miocene interrals, fig. 28) may have furnished a large part of the nutrients required for the diatom enricl nent. This deltaic deposition also accounts for the other 50 percent of the kerogen in the $\mathrm{B}-3$ Miocene, which is herbaceous (plant cuticles, pollen, spores, resins, and waxy material; Smith, 1979). However, the presence of the large Miocene delta does not account for the coldwater nature of the benthic diatom assemblage or the apparently ubiquitous occurrence of rich Miocene diatom assemblages all along the U.S. Atlantic margin. Thus, the rowelling and deltaic deposition may have combired to produce the diatom-rich 0ligocene and Miocene sediments in the Baltimore Canyon trough.

At $4,000 \mathrm{ft}(1,219 \mathrm{~m})$, the riddle Miocene foraminiferal faunas of the CoST No. B-3 well begin to lose the upper slope components. Bulimina marginata, Bulimina elongata, Bulimina alazanensis, Gyroidina, Globobulimina, Melonis barleeanus, and Uvigerina constitute an outer shelf assemblage. At $3,900 \mathrm{ft}(1,189 \mathrm{~m})$, Bulimina elongata becomes the most abundant form, accompanied by Fursenkoina, Brizalina, Florilus, Epistominella, Melonis, Islandiella, Globobulimina, Uvigerina, and Lenticulina; this assemblage extends up to $3,810 \mathrm{ft}(1,161 \mathrm{~m})$, where the top sample was collected. A "middle to outer shelf" environment is inferred, probably of about a 300-ft (100-m) water depth. The paleoenvironments of the remaining unsampled upper part of the viell can be estimated from the other core holes nearby. Presumably, the middle P1locene transgression noted in the Southeast Georgia Eml ayment (Poag and Hall, 1979) and on other ocean margins (Vail and others, 1977) would have produced "upper slope" conditions at the COST No. B-3 well site. Pleistocene strata in the nearhy AMCOR 6021 core (f1gs. 25 and 26) consist of gray to darkgray, gassy, silty and sandy clays. These clays contain planktic foraminifers of temperate-water origin, and benthic foraminiferal associations range from "Inner shelf" to "upper slope" in origin. Several intervals contain abundant dark organic particles and rich diatom floras along with "middle to outer shelf" benthic foraminifers. This association suggests accumulation in low-oxygen depressions on the shelf (Poag, 1978). Holocene sediments have not been differentiated in this study. 


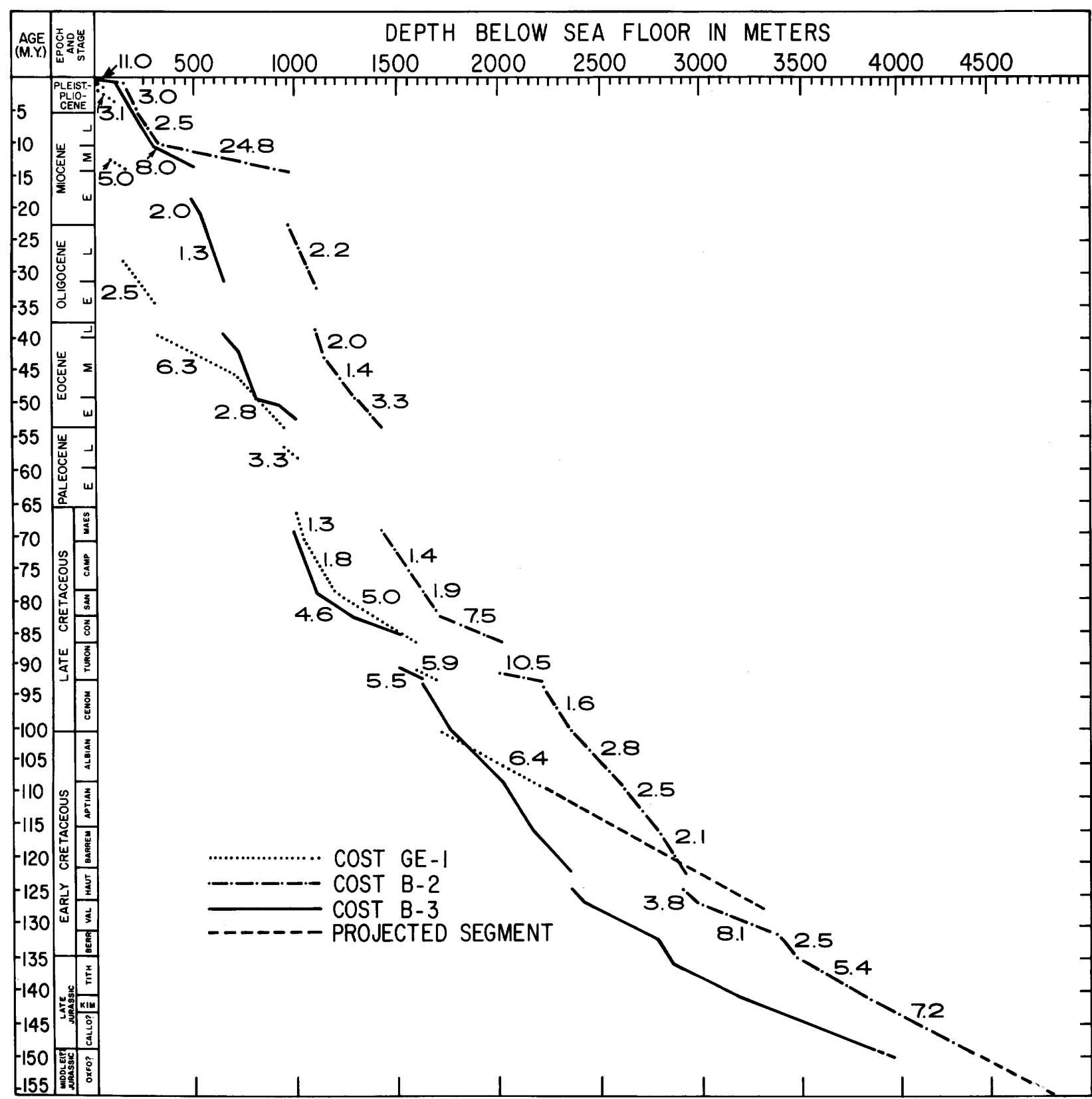

Figure 28.--Comparison of sediment accumulation rates at the COST Nos. GE-1, B-2, and B-3 well sites. Numbers 1isted beside curves for the GE-1 and B-2 wells record sediment accumulation rates in $\mathrm{cm} / 1,000 \mathrm{yrs}$. Rates for the $\mathrm{B}-3$ well are essentially identical to those at B-2, except as noted next to the B-3 curve.

\section{Discussion}

Figure 26 displays the inferred paleoenvironmental sequences (depositional cycles) along USGS Selsmic Line 25 from the COST No. B-2 well on the shelf to $6 \mathrm{ml}(10 \mathrm{~km})$ seaward of ASP 15 on the lower slope. Parts of the section are somewhat diagrammatic and simplified, because the detall known at the well sites could not be shown at the scale of the paleoenvironmental section. In the part of the Baltimore Canyon trough illustrated (and, by selsmic extrapolation, it is inferred to be representative of the ent1re outer part of the trough; see Schlee and Grow, this volume), during the Middle(?) and Late Jurassic and Early Cretaceous, terrestrial environments dominated the B-2 site, and shallow marine (30-to 165-ft depth; 10 to $50 \mathrm{~m}$ ), mixed 
clastic and carbonate environments prevailed at the B-3 site. The shoreline fluctuated back and forth, generally between seismic shot points 2,400 and 2,500 , as inferred from the pattern of selsmic reflections (fig. 26), but occastonally it advanced or retreated considerably beyond this point. The most obvious exceptions are the transgression across the Tithontan-Berriastan boundary and the regression during the early Barremian. This group of rocks (Callovian(?) to Albian) maintains a uniform thickness from the B-2 to approximately the B-3 well site ( $\mathrm{f} 1 \mathrm{~g}$. 25). The fault block penetrated by the $B-3$ well contains a slightly thicker sequence, but the sequence thins rapidly southeastward onto the carbonate platform to approximately one-quarter the thickness at B-3 (Schlee and Grow, this volume; fig. 25). The Upper Jurassic "back reef" carbonate facles in the B-3 well represent the last stages in limestone-deposition associated with the carbonate platform. Shelf sediments began to override the carbonate platform perhaps as early as the Callovian(?) (figs. 25 and 26), and a thick sequence of sedimentary rocks spilled across it during the Hauterivian to Cenomanian interval. Nevertheless, thinning across the platform indicates that it remained as a physiographic high until the beginning of the Cenomanian. After Cenomanian deposition, thinning across the top of the platform ceased (Schlee and Grow, this volume).

Water depths began to increase in the Cenomanian and reached a Cretaceous maximum during the late Santonian and Campanian. Following a late Maestrichtian regression and a Paleocene hiatus, a major early to middle Eocene marine transgression deposited rich "outer shelf" carbonate deposits as far updip as the site of the USGS Island Beach well beneath the New Jersey Coastal Plain (fig. 22), while "lower slope" depths enveloped both the B-2 and B-3 well sites. The Eocene rocks double in thickness from $1,150 \mathrm{ft}(350 \mathrm{~m})$ at the $\mathrm{B}-2$ wel1 to $2,300 \mathrm{ft}(700 \mathrm{~m}), 16 \mathrm{mt}(25 \mathrm{~km})$ landward of the B-2 on an extension of USGS Seismic LIne 25. Presumably, depths equivalent to the modern shelf edge were reached between this location $(16 \mathrm{mI}$ or $25 \mathrm{~km}$ landward of $\mathrm{B}-2$ ) and the Island Beach well, but there appears to have been no physiographic expression of the Eocene shelf edge comparable to that of the Miocene and Quaternary. During the late Oligocene, "slope" deposits continued to accumulate, but the terrestrial components of the rocks increased significantly.

A gradual shallowing from "upper slope" to "Inner and middle shelf" depths took place during the outbuilding of the middle Miocene deltalc wedge. The shelf edge appears to have migrated from shot point 2,300 to about shot point 2,600 during the Miocene, judging from the prograding Miocene selsmic reflectors that have close geometric similarity to those of the Pleistocene (Schlee and Grow, this volume). The thickest Miocene sequence was deposited beneath shot point 2,600 (fig. 25). The variety of Pleistocene paleoenvironments that have been penetrated on the present upper slope is the result of the interplay of glacial sea-level fluctuations and pulses of glaciofluvial clastic deposition. "Shelf" faunas apparently were commonly washed down onto the slope, and the shelf was exposed subaerially during low Pleistocene sea-level stands.

\section{HIATUSES}

The recognition of hiatuses in the Cost Nos. B-3, B-2, and GE-1 wells is lased chiefly on the absence of foraminiferal zones from the observed biostratigraphic sequences. These data are supplemented by paleoenvironmintal interpretations and 1ithologic changes. The oldest disconformity distinguished in tio $\mathrm{B}-3$ well occurs at $\sim 10,500 \mathrm{ft}(3,201 \mathrm{~m})$; it separates the Hauterivian from Barremian rocks ard reflects a time gap of about 3-4 m.y. (time estimated from accumulation-rate curve, fig. 28). The paleoenvironment changes from "middle shelf" conditions in the Hauterivian to nonmarine conditions in the lower Barremian. This change suggests that the disconformity was caused by subaerfal erosion. The lithology changes from a shaley limestone below to a shaley sandstone above the disconformity. The 1ithclogic change produces a significant contrast in interval seismic velocities (Carlson, 1979), which is recorded as a strong reflector on seismic profiles (Schlee and Grow, this volume).

The next oldest significant disconformity (at $\sim 8,225 \mathrm{ft} ; \sim 2,507 \mathrm{~m}$ ) separates "middle to outer shelf" assemblages of the late Cenomanian from "middle shelf" assemblages of the Turonian. The top of Zone UC 3 is missing in the biostratigraphic sequence, and the time gap is estimated to be $\sim 1 \mathrm{~m} \cdot \mathrm{y}$. or less. The rock type changes from a thick quartzose sandstone below to a thick shale sequence above, approximately at the disconformity. The small time interval involved in the hiatus and the slight change in paleobathymetry suggest that this gap was created by submarine erosion at the B-3 site. This disconformity is associated with a distinct reflector on seismic recorts (Carlson, 1979; Schlee and Grow, this volume).

The absence of Zone UC 5 and fart of UC 6 in. the biostratigraphic sequence signifies that the upper boundary of the Turontan rocks in the B-3 well is also a disconformity (at $\sim 7,850 \mathrm{ft}$; $\sim 2,393 \mathrm{~m}$ ). A time gap of $\sim 5$ to $6 \mathrm{~m} \cdot \mathrm{y} \cdot$ is postulated, and an equivalent gap is present at $\mathrm{B}-2$ and at GE-1 (fig. 28). Clearly, the late Turonian and early Coniacian are characterized by a regional regression along the Atlantic margin. The paleoenvironment below the hiatus is "middle shelf" and above is "irner shelf," but the disconformable surface may have been subaerially exposed during the peak regression. The Turonian shale gives ray to dark silty mudstone in the lower Coniacian. This 
horlzon does not appear to produce a slgniflcant seismic reflector; but, on the other hand, it is so close to the disconformity bounding the lower Turonian that they may be inseparable on seismic records.

The next major hiatus occurs at the Cretaceous-Tertiary contact. In the $\mathrm{B}-3$ and $\mathrm{B}-2$ wells, the Paleocene Series (Zones P.1 to P.5) and the upper Maestrichtian (Zones UC 15 to UC 17) are missing. The time gap is 17-18 m.y. At GE-1, a nearly coeval hiatus is present, but part of Zone P.4 (upper Paleocene) is preserved and only Zone UC 17 (uppermost Maestrichtian) is missing from the top of the Cretaceous (fig. 28). To date, this is the most significant regional hiatus in terms of the chronologic gap that has been observed on the Atlantic margin. It can be traced easily on seismic reflection profiles (Carlson, 1979; Schlee and Grow, this volume). At B-3, the "outer shelf" paleoenvironment does not change across the disconformity, but the lithology changes from dark silty mudstone to white biomicritic limestone. The missing section may have been eroded by a series of subaerial and submarine processes during this lengthy period (VaIl and others, 1977; fig. 29).

At B-2, however, the 1ithology and paleoenvironmental conditions are quite different. The Maestrichtian is represented by a lignitic, gypsiferous quartzose sandstone containing a marginal-marine assemblage of agglutinated foraminifers. Subaerial exposure clearly could have existed during or following deposition of this sandstone and prior to deposition of the overlying lower Eocene, "outer shelf," white limestone.

At $\sim 5,975$ ft $(1,821 \mathrm{~m})$ in the $\mathrm{B}-3$ well, a regional hiatus separates the late Eocene Zone P.15 from late Ol1gocene Zones P.21-20. Zones P.19, 18, 17, and 16 are missing, a gap which spans $\sim 8 \mathrm{~m} \cdot \mathrm{y} \cdot$ (fig. 28). This hiatus is also present at $\mathrm{B}-2$ and $\mathrm{GE}-1$ ( $\mathrm{f} 1 \mathrm{~g} .28$ ), although less of the section is missing in these wells. (The minimum gap is at GE-1 where it spans $\sim 5 \mathrm{~m} \cdot \mathrm{y}_{\bullet}$ ) The paleoenvironment on either side of the disconformity at $\mathrm{B}-3$ is equivalent to that of the modern lower slope. At B-2, a change occurs from an "upper slope" environment below the disconformity to an "outer shelf" environment above it. At these sites, as at GE-1 (Poag and Hall, 1979), submarine currents seem to have been the erosive agent.

A lithologic change from white Eocene limestone to olive-gray, glauconitic, 0ligocene clay takes place in both $\mathrm{B}-2$ and $\mathrm{B}-3$. The resulting seismic-velocity contrast forms a distinctive reflector on seismic profiles (Carlson, 1979; Schlee and Grow, this volume).

At $\sim 4,450$ ft $(1,356 \mathrm{~m})$, there is a gap between Zone N.9 of the middle Miocene and Zone N.5? of the lower Milocene. Zones N.8 through N.6 are missing and represent a hiatus of $\sim 5$ m.y. Even greater gaps between the late 01igocene and middle Miocene are present at B-2 $\left(\sim 9 \mathrm{~m} \cdot \mathrm{y}_{\bullet}\right)$ and GE-1 $\left(\sim 14 \mathrm{~m} \cdot \mathrm{y}_{\bullet}\right)$, they confirm the wide areal distribution of this disconformity. At B-3, the paleoenvironment changes from "lower" to "upper slope" depths across the disconformity, while at B-2 the change is from "outer shelf" to "Inner shelf." Sul narine currents appear to have been the erosive agents at both sites. No 1ithologic charge is associated with this disconformity at B-3, but at B-2 a thin quartzose sandstone lies below and olive-gray clay lies above the disconformity.

Several other subaerial erosional events apparently took place in the Miocene, Pliocene, and Pleistocene, as indicated by repeated zones of intensely oxidized microfossils and sediments in the B-2 we11 and in the AMCOR 6009 ard 6010 cores. In these sections, the detailed biostratigraphic zonation required to estimate the time spans represented is not yet completed. None of these disconformities has the reflective strength on seismic profiles that characterizes the older disconformities.

\section{SEDIMENT ACCUMULATION RATES}

Sediment-accumulation-rate curves for the COST Nos. B-2, B-3, and GE-1 wells (Poag and Ha11, 1979) are displayed in figure 29. During the Middle(?) and Late Jurassic, accumilation rates in the $\mathrm{B}-2$ and $\mathrm{B}-3$ areas were uniformly high (2.1 to 3.1 in./1,000 yrs; 5.4 to 7.8 $\mathrm{cm} / 1,000$ yrs) and nearly identical. This is manifest also on figure 25, which shows the uniform thickness of these strata across the outer part of the Baltimore Canyon trough. Throughout the Early Cretaceous and into the Cenomanian, the accumulation rates remained nearly identical at the $B-2$ and $B-3$ sites, but were reduced $(0.8$ to $1.5 \mathrm{in} \cdot / 1,000$ yrs; 2.1 to $3.8 \mathrm{~cm} / 1,000$ yrs, with the exception of a Valanginian pulse of 2.8 to 3.2 in./1,070 yrs; 7.0 to $8.1 \mathrm{~cm} / 1,000 \mathrm{yrs})$. Rates were considerably higher coevally at the GE-1 site in the Southeast Georgia Embayment (2.5 in./1,000 yrs; $6.4 \mathrm{~cm} / 1,000$ yrs). A pulse of Increased accumulation affected the $\mathrm{B}-2$ and $\mathrm{B}-3$ sites in the Turonian ( 2.2 to $4.1 \mathrm{in} . / 1,000 \mathrm{yrs} ; 5.5$ to $10.5 \mathrm{~cm} / 1,000 \mathrm{yrs})$, but was not effective at GE1 (reduced slightly to 2.2 in./1,000 yrs; 5.5 $\mathrm{cm} / 1,000 \mathrm{yrs})$. Conlacian and Santonian rates remained high (1.8 to $2.6 \mathrm{in} . / 1,000 \mathrm{yrs} ; 4.6$ to $6.5 \mathrm{~cm} / 1,000 \mathrm{yrs})$ at $\mathrm{B}-3$, but at B-2 Santonian rates were reduced to 0.8 in./1,000 yrs $(1.9$ $\mathrm{cm} / 1,000$ yrs). All three COST well sites experienced reduced rates during the Cempanian and early Maestrichtian $(0.5$ to $0.6 \mathrm{ir} \cdot / 1,000$ yrs; 1.3 to $1.4 \mathrm{~cm} / 1,000$ yrs).

During the Cenozoic, the rates are noticeably less tiniform between the Baltimore Canyon trough and the Southeast Georgia Embayment. Early Eocene rates are similar (1.1 to $1.5 \mathrm{in} . / 1,000 \mathrm{yrs}$; 2.8 to $3.9 \mathrm{~cm} / 1,000 \mathrm{yrs})$, but in the middle and late Eocene, the rates dramatically increase at the GE-1 site (2.5 in. $/ 1,000 \mathrm{yrs} ; 6.3 \mathrm{~cm} / 1,000 \mathrm{yrs}$ ) and decrease in 


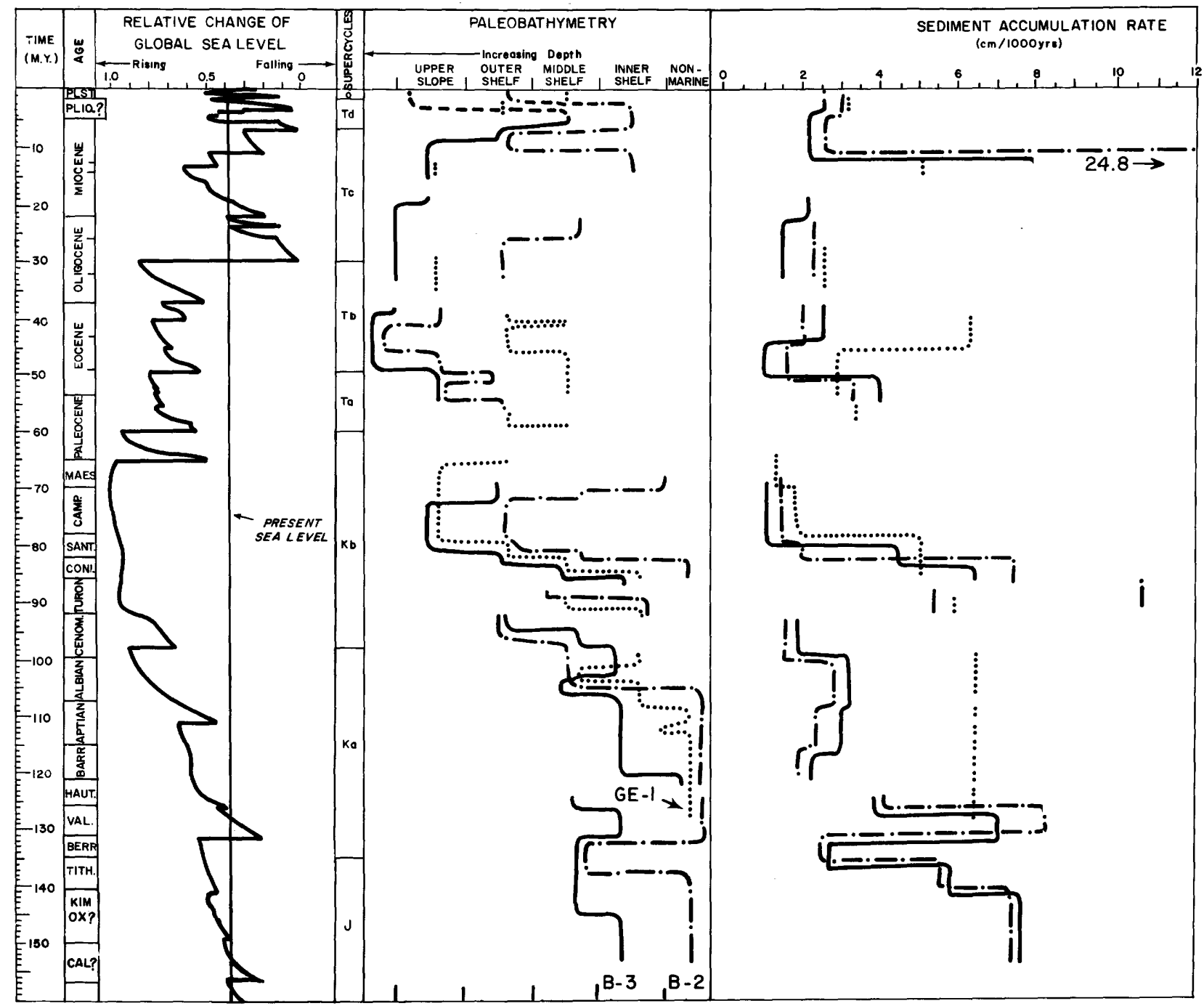

Figure 29.--Comparison of global sea-level changes (Vail and others, 1977) with paleobathymetry and sediment accumulation rates at the COST Nos. GE-1, B-2, and B-3 well sites. The sediment accumulation rate for the middle Miocene at site B-2 lies off the scale of the chart at $9.8 \mathrm{in} . / 1,000$ yrs $(24.8 \mathrm{~cm} / 1,000 \mathrm{yrs})$.

$\mathrm{B}-2$ and $\mathrm{B}-3 \quad(0.4$ to $0.9 \mathrm{1n.} / 1,000 \mathrm{yrs} ; 1.0$ to $2.4 \mathrm{~cm} / 1,000$ yrs). The 011 gocene rates are similar at B-3 and GE-1 (0.9 to $1.0 \mathrm{in} \cdot / 1,000$ yrs; 2.2 to $2.5 \mathrm{~cm} / 1,000$ yrs), but about half as great at B-2 $(0.5 \mathrm{in} . / 1,000 \mathrm{yrs} ; 1.3 \mathrm{~cm} / 1,000$ yrs). In the middle Miocene, a significant increase occurs at each site $(2.0 \mathrm{in} . / 1,000 \mathrm{yrs}$; $5.0 \mathrm{~cm} / 1,000 \mathrm{yrs})$ at $\mathrm{GE}-1 ; 3.2 \mathrm{in.} / 1,000 \mathrm{yrs}$ $(8.0 \mathrm{~cm} / 1,000$ yrs) at $\mathrm{B}-3)$, but the increase at $\mathrm{B}-2$ is by far the most dramatic at any site $(9.8$ In./1,000 yrs; $24.8 \mathrm{~cm} / 1,000$ yrs). Pllocene rates are poorly documented, but appear to range from 1.0 to $1.2 \mathrm{in.} / 1,000$ yrs $(2.5$ to 3.1 $\mathrm{cm} / 1,000$ yrs). At $\mathrm{GE}-1$, Quaternary rates remain about the same as Pllocene rates $(1.0 \mathrm{in} / 1,000$ yrs; $2.5 \mathrm{~cm} / 1,000 \mathrm{yrs})$, but at $\mathrm{B}-2$ and $\mathrm{B}-3$ another pulse of terrestrial sedimentation ralsed rates to $4.3 \mathrm{in}$. and $3.9 \mathrm{in} . / 1,000$ yrs (11 cm and $10 \mathrm{~cm} / 1,000 \mathrm{yrs}$ ), respectively.

\section{SEA-LEVEL FLUCTUATIONS AND DEPOSITIONAL CYCLES}

A comparison of global sea-level cycles (Vail and others, 1977) and the depositional (paleobathymetric) and sediment-accumulation cycles observed in the COST Nos. B-2, B-3, and GE-1 wells are shown in figure 29. In general, the correspondence of deep and shallow bathymetry with high and low sea levels, respectively, is remarkably close; and the supercycles of Vail and others (1977) can be recognized. The Middle(?) to Late Jurassic supercycle (J) began with nonmarine to "inner shelf" deposition and culminated across the Tithonian-Berriasian boundary with "middle shelf" deposition.

Deposition of supercycle $\mathrm{K} \hat{c}$ began in nonmarine to "inner shelf" water depths in the valanginian and reached "middle shelf" depths in 
the lower to middle part of the Alblan. A Cenomanian hiatus marks the base of supercycle $\mathrm{Kb}$ in GE-1, but not in the $\mathrm{B}-2$ and $\mathrm{B}-3$ wells. In both latter wells, however, the lower Cenomantan rocks are of shallower water origin than the upper Cenomanian rocks. Subsequent to the "outer shelf" deposition of the late Cenomanian, a minor hiatus was followed by "inner to middle shelf" deposits of the lower Turonian in each we11. The major hiatus at the top of the Turonian effectively divides supercycle $\mathrm{Kb}$ into two subcycles, as the generalized curve of Vail and others (1977) seems to suggest. The upper subcycle peaked in the Santonian, Campanian, and early Maestrichtian with "outer shelf to upper slope" deposition, and terminated, after a late Maestrichtan regression, in a major hiatus.

Deposits of supercycle $\mathrm{Ta}$ are only fragmentarily represented in each well, and its cyclical nature cannot be distinguished. Supercycle $\mathrm{Tb}$, however, is well represented at all three sites. The Eocene part of this supercycle began with "middle shelf to upper slope" deposition in the lower Eocene, peaked as "outer shelf to lower slope" deposits in the middle Eocene, and terminated after a late Eocene regression in a major hiatus in which the upper Eocene and lower 0ligocene (upper half of supercycle $\mathrm{Tb}$ ) were eroded (although part of the lower 011 gocene remains at $\mathrm{GE}-1$ ). This late Eocene-early 0ligocene hiatus is evidently the result of the dramatic sea-level drop that is postulated for the middle Oligocene (Vail and others, 1977).

Supercycle Tc began in the Baltimore Canyon trough with late 0ligocene deposition in "outer shelf" and "lower slope" depths. A slight shallowing noted at B-2 and B-3 was follorred by an early Miocene hiatus which also affected the GE-1 site. At GE-1, and at other drill sites in the Southeast Georgla Embayment, this erosional event removed upper oligocene as well as M:ocene rocks. The middle of supercycle Tc (middle Miocene) is represented by sustained terrestrial outbuilding at the $\operatorname{CosT}$ Nos. $\mathrm{B}-2$ and $\mathrm{B}-3$ well sites. Deltaic progradation in the outer Baltimore Canyon trough was rapid enough to keep pace with the rise in sea level and priduced shallow-water deposits as far seaward as $\sim 12 \mathrm{mi}$ $(\sim 20 \mathrm{~km})$ downdip from the B-2 site (fig. 26). The lack of biostratigraphic definition h?mpers clear recognition of the remaining supercycles, but the top of Tc seems to be represented at B-2 and B-3 by shoaling to "middle and Inner shelf" depths. TC is not represented at GE-1, having been removed by early Pliocene erosion which began supercycle $\mathrm{Td}$.

Supercycle $T d$ is represented by middle Pliocene "upper slope" deposits at GE-1, and by undifferentiated Pliocene of "outer shelf" and presumably "upper-slope" depths at B-2 and B-3 respectively. The details of Quaternary depositional cycles have yet to be worked out. 



\section{CALCAREOUS NANNOFOSSIL BIOSTRATIGRAPHY, PALEOENVIRONMENTS, AND}

POST-JURASSIC CONTINENTAL MARGIN DEVELOPMENT

Page C. Valentine

The $\operatorname{cosT}$ No. B-3 well penetrated $13,134 \mathrm{ft}$ $(4,003 \mathrm{~m})$ of sedimentary rock, and samples ranging in age from middle Miocene to Late Jurassic were collected over a 12,000-ft $(3,658-$ $m$ ) interval. Hiatuses in the stratigraphic record are apparent in the lower Miocene, middle and lower Oligocene, Paleocene, and upper Maestrichtian. Both marine and nonmarine environments existed during Late Jurassic-Early Cretaceous time, whereas marine environments prevalled during the Late Cretaceous and Cenozolc. In Cretaceous time, sediments accumulated rapidly at the COST No. B-3 well site, chiefly at shelf depths on a slowly subsiding, aggrading margin. However, Cenozolc sediments were deposited at slope depths on a relatively rapidly subsiding margin that became progradational in post-0ligocene time. Calcareous nannofossils are present throughout most of the section, but barren intervals exist within Jurassic, Lower Cretaceous, and Cenomanian strata. Selected nannofossil species that are of biostratigraphic significance in the Lower Cretaceous section are illustrated in plates 1 and 2. Preliminary studies of calcareous nannofossils found in the COST No. B2 well drilled on the outer Continental Shelf 30 $\mathrm{mi}(50 \mathrm{~km})$ to the north (Smith and others, 1976; Valentine, 1977) have been re-evaluated in light of the findings of the present study and the Tertiary and Upper Cretaceous stratigraphy of the two well sites are similar in many respects.

Calcareous nannofossil biostratigraphy of the CosT No. B-3 well (f1g. 30) is based primarily on the study of rotary drill cuttings collected over $10-$ to $30-\mathrm{ft}$ (3- to 9-m) intervals. With few exceptions, cuttings were analyzed at intervals of $100 \mathrm{ft}(30 \mathrm{~m})$ or less, beginning with the first sample which was collected at 3,810 ft $(1,161 \mathrm{~m})$ and ending at 15,800 ft $(4,816$ m) (fig. 30) A complete sequence of samples was studied from 4,560 to $5,370 \mathrm{ft}(1,390$ to $1,637 \mathrm{~m})$. Smear slides were made from individual rock fragments representing each of the lithologic units present in a single cuttings sample. The oldest nannofossil assemblage identified in a sample was used to determine the age of the strata at that level.
Species listed as representative of a stratigraphic interval do not necessarlly occur in every sample studied from that interval. In a11, 572 samples from 243 levels in the well were studied. Sample depth are relative to the Kelly Bushing and total depth of the well was $15,820 \mathrm{ft}(4,822 \mathrm{~m})$. The reports on the $\operatorname{cosT}$ No. B-3 we11 by International Biostratigraphers, Inc. (1979) and Amato and Simonis (1979) were consulted; selected information, as cited, has been incorporated into the present study.

\section{BIOSTRATIGRAPHY}

Miocene $(3,810-4,710 \mathrm{ft} ; 1,161-1,436 \mathrm{~m})$

Calcareous and diatomaceous mudstone chiefly of middle Miocene age and at least 900 $\mathrm{ft}(274 \mathrm{~m})$ thick is present from $3,81 \mathrm{C}$ to 4,710 ft $(1,161$ to $1,436 \mathrm{~m})$. Diatoms are abundant and well preserved in most of the samplen studied from this interval, whereas the abundance of calcareous nannofossils varies from few to common and preservation is moderate to good. Many of the calcareous nannofossil srecies in this sequence are long-ranging; the: include Coccolithus eopelagicus, $C$. pelagicus, Cyclicargolithus floridanus, Cyclococsolithina macintyrei, Discoaster brouweri, D. challengeri, D. deflandrei, D. variabilis, Discolitrina spp., Helicosphaera carteri, and Reticulofenestra pseudoumbilica.

The Mlocene interval comprisesmiddle Miocene strata from 3,810 to $4,620 \mathrm{ft}(1,161$ to $1,408 \mathrm{~m})$, and slightly older beds of late early to early middle Miocene age that extent down to 4,710 ft $(1,436 \mathrm{~m})$. Discoaster exilis is consistently present in the middle Miocene cuttings down to 4,620 ft $(1,408 \mathrm{~m})$, and Discoaster bollii ranges from 4,320 to $4,650 \mathrm{ft}$ $(1,317$ to $1,417 \mathrm{~m})$. The highest occurrence of Helicosphaera intermedia is at $4,500 \mathrm{ft}(1,372$ $\mathrm{m})$ and of Coronocyclus nitescens, at 4,560 ft $(1,390 \mathrm{~m})$.

Strata of late early to early middle Miocene age are recognized by the highest occurrence of Sphenolithus heteromorchus in a sample from 4,620 to 4,650 ft $(1,408$ to 1,417 


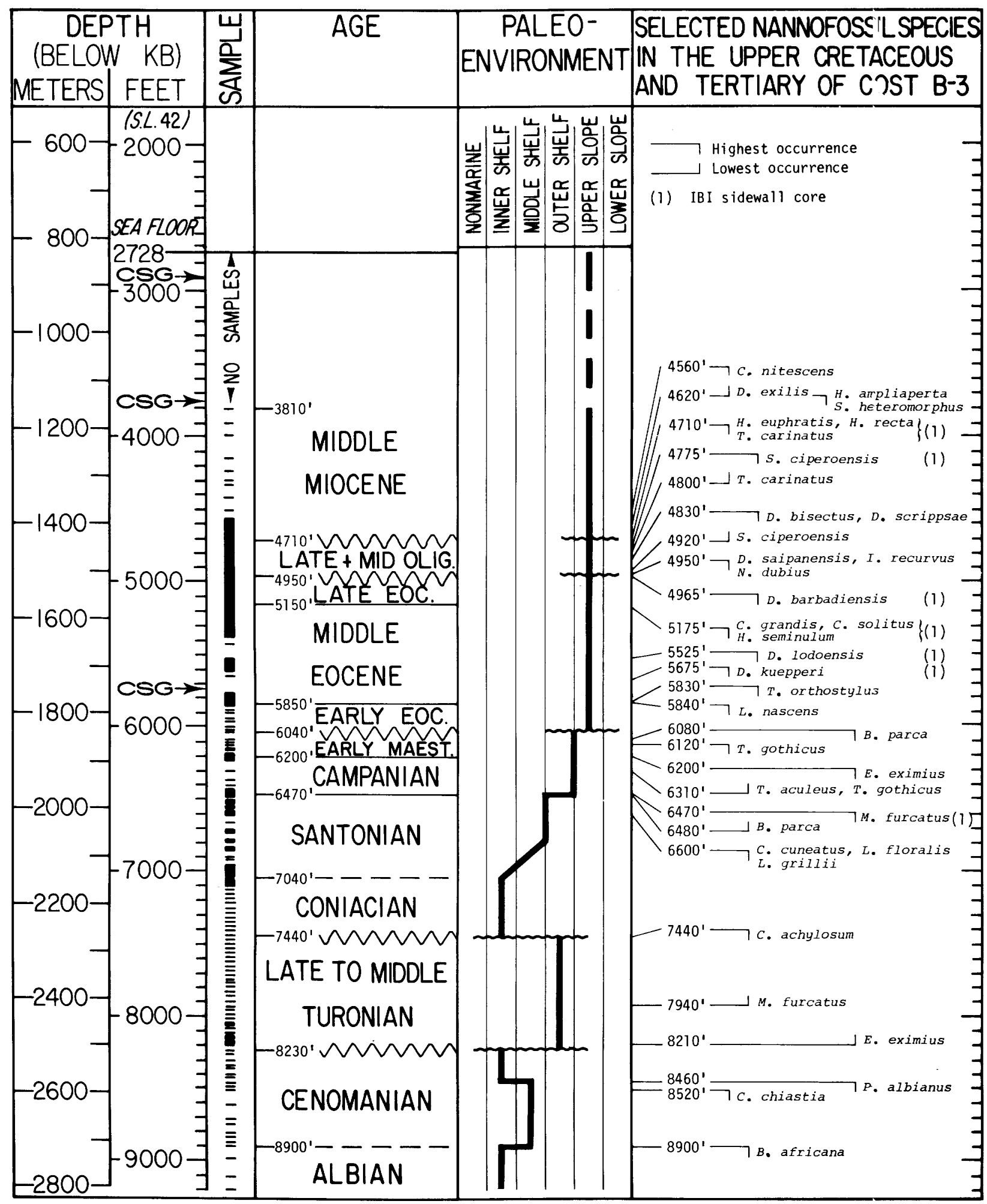

Figure 30.--Calcareous nannofossil biostratigraphy and paleoenvironments of the COST No. B-3 $2,686 \mathrm{ft}(819 \mathrm{~m})$. CSG, casing point, IBI, International Biostratigraphers, Inc. In on findings of this study but incorporate some biostratigraphic information from 


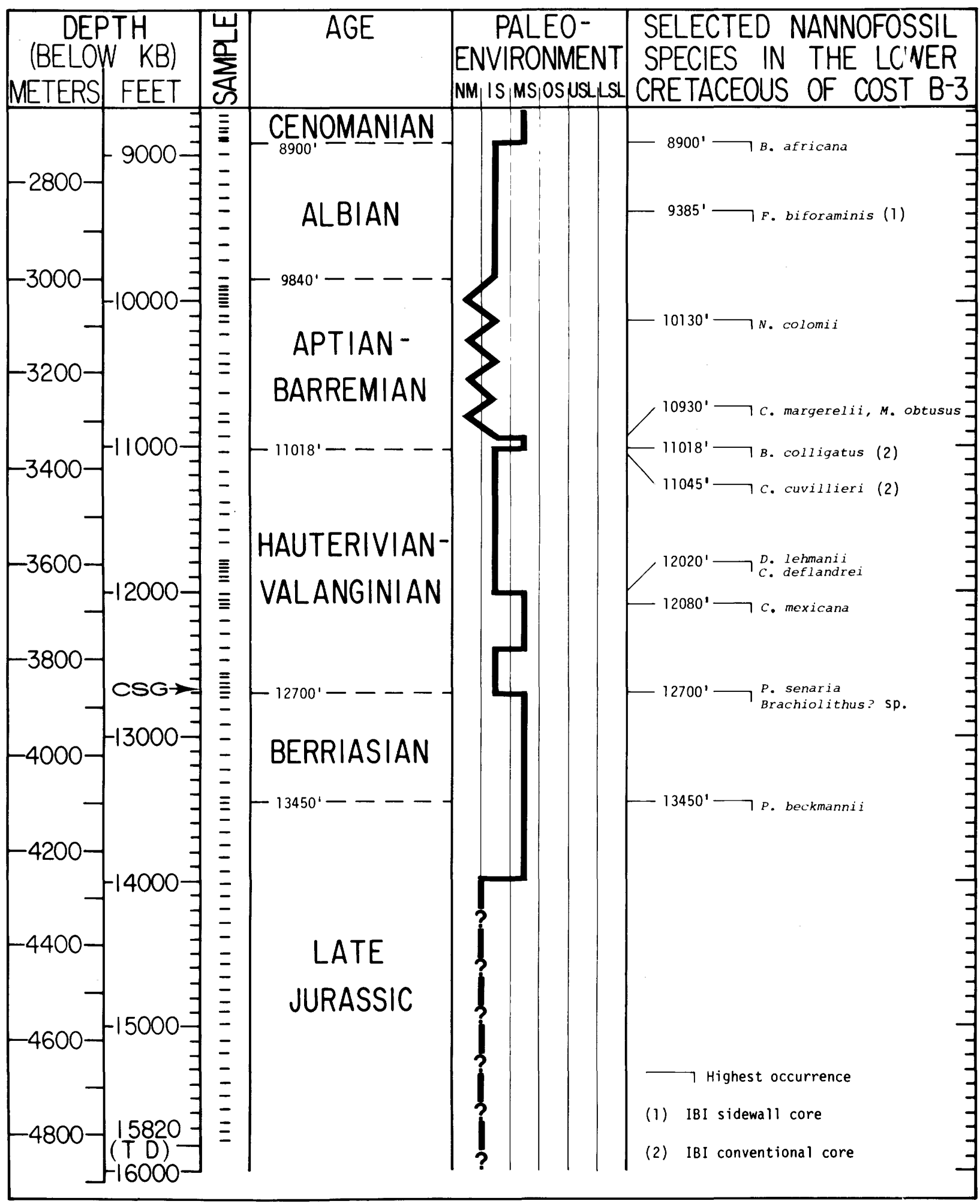

well. Depths are relative to the Kelly Bushing (KB), $42 \mathrm{ft}(13 \mathrm{~m})$ above sea level. Water depth sample column, blacked-in areas indicate a complete sequence of samples studied. Ages are based Internationa1 Biostratigraphers, Inc. (1979). 
m). This species is a biostratigraphic marker restricted to the Sphenolithus heteromorphus and Helicosphaera ampliaperta zones of Bukry (1973, 1975). Sphenolithus heteromorphus and Helicosphaera ampliapertura are both found in cuttings from $4,620 \mathrm{ft}(1,408 \mathrm{~m})$ down to 4,740 ft $(1,445 \mathrm{~m})$. However, a sidewall core from $4,710 \mathrm{ft}(1,436 \mathrm{~m})$ contains an upper 01igocene calcareous nannofossil assemblage (International Biostratigraphers, Inc., 1979), and therefore the maximum extent of upper lower to lower middle Miocene beds is from 4,620 to $4,710 \mathrm{ft}$ $(1,408$ to $1,436 \mathrm{~m})$. An unconformity representing most of the lower Miocene exists between this sequence and the underlying upper oligocene.

At the COST No. B-2 well site, an equivalent interval of diatomaceous middle Miocene strata is present from about 2,800 to 3,520 ft $(853$ to $1,073 \mathrm{~m})$. These beds are barren of calcareous nannofossils and have been dated through the study of foraminifers (Smith and others, 1976; Poag, 1977).

\section{Oligocene $(4,710-4,950 \mathrm{ft} ; 1,436-1,509 \mathrm{~m})$}

The unconformable upper oligocene-middle Miocene contact is at $4,710 \mathrm{ft}(1,436 \mathrm{~m})$, coincident with the highest occurrences of Helicosphaera euphrati, $H$. recta, and Triquetrorhabdulus carinatus reported from a sidewall core by International Blostratigraphers, Inc. (1979). The 011gocene is a 240-ft (73-m) sequence of calcareous and diatomaceous mudstone, less calcareous but otherwise 1ithologically similar to the overlying Miocene strata. Calcareous nannofossils are common to abundant, and preservation is moderate to good. Species that range throughout this interval include Coccolithus eopelagicus, C. pelagicus, Coronocyclus nitescens, Cyclicargolithus abisectus, C. floridanus, Discoaster deflandrei, Discolithina spp., Helicosphaera euphratis, $H$. intermedia, $H$. obliqua, $H$. recta, Reticulofenestra cf. R. scissurus of Bramlette and Wilcoxon (1967), Sphenolithus dissimilis, and zygrhablithus bijugatus.

Upper 0ligocene strata of the lower part of the Triquetrorhabdulus carinatus zone (Bukry, $1973,1975)$ are present from 4,710 to $4,830 \mathrm{ft}$ $(1,436-1,472 \mathrm{~m})$ and are recognized by the presence of Triquetrorhabdulus carinatus in association with the species listed above.

Somewhat older beds of late middle to early late oligocene age that represent the Sphenolithus ciperoensis zone (Bukry, 1973, 1975) are present from 4,830 to 4,950 ft $(1,472$ to $1,509 \mathrm{~m})$ and contain the diagnostic species Dictyococcites bisectus, D. scrippsae, and Sphenolithus ciperoensis, whereas Triquetrorhabdulus carinatus is not present. An abrupt change to an upper Eocene calcareous nannofossil assemblage at the base of this interval $(4,950 \mathrm{ft} ; 1,509 \mathrm{~m})$ indicates that middle and lower o1igocene strata are absent.
In the COST No. B-2 well, a similar oligocene sequence is present. Upper Oligocene beds representing the Triquetrorhabdulus carinatus zone (Bukry, 1973, 1975) extend from 3,580 to $3,730 \mathrm{ft}(1,091$ to $1,137 \mathrm{~m})$; and strata of late middle to early late oligocene age (Sphenolithus ciperoensis zone of Bukry, 1973, 1975) are present from 3,790 to $4,050 \mathrm{ft}(1,155$ to $1,234 \mathrm{~m}$ ).

\section{Eocene $(4,950-6,040 \mathrm{ft} ; 1,509-1,841 \mathrm{~m})$}

Beneath the 011gocene calcarecus mudstone, a sequence of Eocene argillaceor's 11mestone $1,090 \mathrm{ft}(323 \mathrm{~m})$ thick is present down to 6,040 ft $(1,841 \mathrm{~m})$, where it unconformably overlies lower Maestrichtian calcareous shale.

Upper Eocene limestone extends for $200 \mathrm{ft}$ $(61 \mathrm{~m})$ from 4,950 to 5,150 ft $(1,509$ to 1,570 m). These beds contain abundant, we11-preserved calcareous nannofossils. The top of the upper Eocene is placed at the highest occurrences, at 4,950 ft $(1,509 \mathrm{~m})$, of Blac'itites spp., Cyclococcolithina formosa, Discoaster nodifer, D. saipanensis, Helicosphaera compacta, $H$. reticulata, Isthmolithus recurvus, Reticulofenestra callida of Bybell (1975), $R$. umbilica, Sphenolithus predistentus, Transversopontis obliquipons, and T. zigzag; and the highest occurrence of another important species, Discoaster barbadiensis, is in a sidewall core from somewhat deeper in the well at 4,965 ft $(1,513 \mathrm{~m}$ ) (Tnternational Biostratigraphers, Inc., 1979). Two of these species (Discoaster barbadiensis, D. saipanensis) are not known to range above the Eocene, whereas the highest occurrances of the other species are coincidental only because lower and middle oligocene strata are missing from the CosT No. B-3 well section. other species that are typical of the upfer Eocene in this well are Cyclicargolithus floridanus, Dictyococcites bisectus, $D$. scrippsae, Discolithina spp., Helicosphaera euphratis, $H$. wilcoxonii, and Zygrhablithus bijugatus. Chiasmolithus oamamensis and Reticulofenestra reticulata are present and are restricted to the upper Eocene of the COST No. B-3 we11. Most of the sequence that is assigned a late Eocene age is equivalent to the Discoaster barbadiensis zone of Bukry (1973, 1975).

As is the case with the Miocene and oligocene parts of this section, the Eocene interval in the COST No. B-3 well is comparable to the Eocene of the COST No. B-2 well. Upper Eocene beds of the Discoaster barbcdiensis zone (Bukry, 1973, 1975) are present in the B-2 we11 from 4,080 to $4,320 \mathrm{ft}(1,244$ to $1,317 \mathrm{~m})$.

The top of the middle Eocene is placed at $5,150 \mathrm{ft}(1,570 \mathrm{~m})$, halfway between two sidewall cores studied by International Biostratigraphers, Inc. (1979). The highest occurrences of Chiasmolithus grandis, $C$. solitus, and Helicosphaera seminulum were observed in a sidewall core from $5,175 \mathrm{ft}(1,577$ 
m) (International Biostratigraphers Inc., 1979) and in the cuttings samples from $105 \mathrm{ft}(32 \mathrm{~m})$ lower, at $5,280 \mathrm{ft}(1,609 \mathrm{~m})$. Calcareous nannofossils are common to abundant, but their preservation is noticeably poorer than it is in the overlying strata. Middle Eocene limestone is about $680 \mathrm{ft}(207 \mathrm{~m})$ thick and is present from 5,150 to about 5,830 ft $(1,570$ to 1,777 m). Calcareous nannofossil species that are typical of this interval include Cepekiella Lumina, Chiasmolithus gigas (rare), C. grandis, C. solitus, Coccolithus eopelagicus, $C$. pelagicus, Cyclicargolithus floridanus, Cyclococcolithina formosa, C. gammation, Discoaster barbadiensis, D. saipanensis, Helicosphaera lophota, $H$. intermedia, $H$. seminulum, Neococcolithes dubius, Sphenolithus radians, Transversopontis obliquipons, and Zygrhablithus bijugatus. In addition, the highest occurrences of Campyzosphaera dela, Discoaster diastypus, D. Zodoensis, and Discoasteroides kuepperi are in the lower part of the middle Eocene in the CosT No. B-3 well. In the $\cos T$ No. B-2 well, middle Eocene beds of the same age are present from 4,380 to $4,800 \mathrm{ft}$ $(1,335$ to $1,463 \mathrm{~m})$.

Lower Eocene 1imestone extends from about 5,850 to 6,040 ft $(1,783$ to $1,841 \mathrm{~m})$. International Biostratigraphers, Inc. (1979) placed the top of the lower Eocene at the highest occurrence of Discoaster lodoensis in a sidewall core from 5,525 ft $(1,684 \mathrm{~m})$. The boundary between the lower and middle parts of the Eocene Series falls within the Discoaster lodoensis zone of Bukry (1973), as shown by Perch-Nielsen (1977, table 3). In the present study, recognition of the top of the lower Eocene is based on the ranges of eight species rather than on the highest occurrence of a single species. In cuttings samples from the CosT No. B-3 well, the following pattern of species ranges, which overlap at about $5,850 \mathrm{ft}$ $(1,783 \mathrm{~m})$, are recognized. Several species are present that elsewhere are most commonly observed in the middle Eocene but that range down into the uppermost lower Eocene. These species and their lowest occurrences in the B-3 we11 are Chiasmolithus grandis $(5,890-5,900 \mathrm{ft}$; $1,795-1,798 \mathrm{~m})$, Discoaster mirus $(5,870-5,880$ $\mathrm{ft}$; $1,789-1,792 \mathrm{~m})$, Helicosphaera Zophota $(5,890-5,900 \mathrm{ft} ; 1,795-1,798 \mathrm{~m})$, and $H$. seminulum $(5,890-5,900$ ft; $1,795-1,798 \mathrm{~m})$. Discoaster sublodoensis, usually restricted to middle Eocene strata, is present from 5,520 to 5,880 ft $(1,682$ to $1,792 \mathrm{~m})$ in the $\mathrm{B}-3$ well. Two species are present that are generally found in the lower Eocene but that range up into the lowermost middle Eocene; these species and their highest occurrences in the $\mathrm{B}-3$ well are Lophodolithus nascens $(5,840-5,850 \mathrm{ft} ; 1,780-$ $1,783 \mathrm{~m})$ and Tribrachiatus orthostylus (5,830$5,840 \mathrm{ft} ; 1,777-1,780 \mathrm{~m})$. The ranges of Discoaster lodoensis and Discoasteroides kuepperi are known to overlap the lower Eocenemiddle Eocene boundary; in the B-3 well they are present from their highest occurrences in sidewa11 cores at $5,525 \mathrm{ft}(1,684 \mathrm{~m})$ and 5,675 ft $(1,730 \mathrm{~m})$, respectively (International Biostratigraphers, Inc., 1979), down to 6,040 ft $(1841 \mathrm{~m})$. Coccolithus magnicrassus is a species that, when first described (Bukry, 1971), was known only from the Discoaster Lodoensis zone; it is present from 5,810 to $6,040 \mathrm{ft}(1,771$ to $1,841 \mathrm{~m})$ in the $\operatorname{CoST}$ No. $\mathrm{B}-3$ we11. Other species that are represented in the lower Eocene in the B-3 well are Campylosphaera dela, Coccolithus eopelagicus, C. jugatus of ProtoDecima and others (1975), C. pelagicus, $C$. petrinus, Cyclococcolithina formosa, Discoaster barbadiensis, D. diastypus, Discoasteroides megastypus, Sphenolithus radians, Transversopontis fimbriatus, Zygrhablithus bijugatus, and, in the upper part, Cycloccolithina gammation. The lower Eocene strata are eqivalent to the Discoaster Lodoensis and Tribrachiatus orthostylus zones of Bukry (1973), and are coeval with the lower Eocene beds that extend from 4,850 to 5,020 ft $(1,478$ to $1,530 \mathrm{~m}$ ) in the $\operatorname{CosT}$ No. B-2 wel1.

The Eocene 1imestone beds overlie lorer to middle Maestrichtian calcareous shale. The missing Paleocene and lowermost Eocene strata represent a major unconformity in the stratigraphic section of the COST No. B-3 well that is also present in the COST NO. B-2 well and may be widespread on the outer Continental Margin in this region.

\section{Maestrichtian $(6,040-6,200 \mathrm{ft} ; 1,841-1,8 ? 0 \mathrm{~m})$}

The Upper Cretaceous-Tertlary boundary is placed at $6,040 \mathrm{ft}(1,841 \mathrm{~m})$, where 11ght-gray, lower Eocene limestone overlies medium- to darkgray calcareous shale containing lower to middle Maestrichtian calcareous nannofossil assemblages. The Upper Cretaceous section is approximately $2,860 \mathrm{ft}(872 \mathrm{~m})$ thick, extending down to the $8,900-f t(2,713-\mathrm{m})$ level. It is composed chlefly of gray calcareous mudstone and shale and includes a section rich in glaucnitic sandstone, several intervals of quartz sandstone, and minor beds of 11mestone and dolomite. Calcareous nannofossil assemblages are diverse and contain species that are common to abundant and generally moderately to well preserved. Upper Cretaceous nannofloras contain many long-ranging species that are present throughout most of the interval: Ahmuelierella octoradiata, Braarudosphaera bigelowii, Chiastozygus plicatus, Corollithion signum, Cretarhabdus conicus, $C$. coronadventis, $C$. crenulatus, Cribrosphaerella ehrenbsrgii, cylindralithus asymetricus, c. coronatus, Eiffellithus eximius, $E$. turriseiffeli, Gartnerago costatum, G. segmentatum, Kamptnerius magnificus, $K$. punctatus, Lithastrinus floralis, L. griliii, Lithraphidites camiolensis, Lucianorhabdus cayeuxi, Manivitella permatoidea, Micula staurophora, Parhabdolithus angustus, $P$. embergeri, $P$. splendens, 
Prediscosphaera cretacea, Stephanolithion laffittei, Tetralithus obscurus, T. ovalis, Vagalapilia matalosa, Watznaueria barnesae, Zygodicus acanthus, Z. diplogrammus, and $Z$. fibuliformis. The occurrences of stratigraphic marker species are discussed later.

Strata of early to middle Maestrichtian age are present in a $160-\mathrm{ft} \quad(49-\mathrm{m})$ interval from 6,040 to $6,200 \mathrm{ft}(1,841$ to $1,890 \mathrm{~m})$ in the COST B-3 well and contain Broinsonia parca, Tetralithus aculeus, T. gothicus, and T. trifidus. At the $\cos T$ No. B-2 well site, Maestrichtian sandstone is present from 5,020 to 5,400 ft $(1,530$ to $1,646 \mathrm{~m})$.

Campanian $(6,200-6,470 \mathrm{ft} ; 1,890-1,972 \mathrm{~m})$

Campanian calcareous shale at least $270 \mathrm{ft}$ $(82 \mathrm{~m})$ thick is present from 6,200 to $6,470 \mathrm{ft}$ $(1,890$ to $1,972 \mathrm{~m})$. The top of the sequence is placed at the highest occurrence of Eiffellithus eximius observed in the present study, and the base at the highest occurrence of Marthasterites furcatus in a sidewall core reported by International Biostratigraphers, Inc. (1979). The lowest occurrence of Broinsonia parca, a species restricted to strata of Campanian and early Maestrichtian age, is from 6,470 to 6,480 ft $(1,972$ to $1,975 \mathrm{~m})$ in a cuttings sample of this study. In the CosT No. B-2 well, calcareous shale of Campanian age is present from 5,400 to about 5,750 ft $(1,646$ to 1,753 m).

Rock chips of Campanian age dominate cuttings samples in the COST No. B-3 well down to about the $9,400-\mathrm{ft}(2,865-\mathrm{m})$ level. The caliper $\log$ run from $12,689 \mathrm{ft}(3,868 \mathrm{~m})$ up to $5,764 \mathrm{ft}(1,757 \mathrm{~m})$ shows that the drill hole from 6,200 to $6,700 \mathrm{ft}(1,890$ to $2,042 \mathrm{~m})$ is wider than $18 \mathrm{in.}$, the maximum value recorded on the log, although it was drilled with a $121 / 4$ -in. bit. The extensive down-hole contamination makes it difficult to delineate the underlying Santonian and Coniacian part of the section.

\section{Santonian-Coniacian $(6,470-7,440 \mathrm{ft}$; $1,972-2,268 \mathrm{~m})$}

The top of the 970-ft (296-m) SantonianConiacian interval is placed at the highest occurrence of Marthasterites furcatus in a sidewa11 core from 6,470 ft $(1,972 \mathrm{~m})$ (International Biostratigraphers, Inc., 1979). Glauconite grains are present as a rare or minor fraction of the cuttings from about $6,270 \mathrm{ft}$ $(1,911 \mathrm{~m})$ downward, but at $6,480 \mathrm{ft}(1,975 \mathrm{~m})$ they become common and remain an important component of the cuttings samples down to about $7,040 \mathrm{ft}(2,146 \mathrm{~m})$. The strata from 6,480 to 7,040 ft $(1,975$ to $2,146 \mathrm{~m})$ appear to be composed of friable glauconitic silt and sand. Although samples from this part of the well are contaminated with Campanian cuttings, an examination of the relatively few intact glauconitic rock chips has shown that they contain calcareous nannofossils of SantonianConiacian age. Chiastozygus cunsatus and Lithastrinus floralis, two stratigraphically important species restricted to Santonian and older strata, are not present above $6,600 \mathrm{ft}$ $(2,012 \mathrm{~m})$ in the $\operatorname{cosT}$ No. B-3 well.

The Santonian and Conlacian cannot be differentiated using calcareous narnofossils, but the glauconitic beds that are present from 6,480 to 7,040 ft $(1,975$ to $2,146 \mathrm{~m})$ are provisionally assigned to the Santonian. From $7,040 \mathrm{ft}$ to $7,440 \mathrm{ft}(2,146$ to $2,268 \mathrm{~m})$, where the highest sample of Turonian age was observed, the rock chips are chiefly Campanian cavings, and the rare glauconitic chips of SantonianConiacian age are probably also cavings from above. In contrast, the unconsolidated sediment in the cuttings samples from this interval $(7,040-7,440 \mathrm{ft} ; 2,146-268 \mathrm{~m})$ is silty, fine sand containing mica, lignite, large pyrite crystals, dolomite, and fragments of mollusks, including oyster shells and prisms of Inoceramus valves. These poorly lithified strata are assigned to the Coniacian and are indicative of an Inner shelf depositional environment in which calcareous nannofossils are poorly represented. In the COST No. B-2 we11, Santonian and Coniacian sandstone and calcareous shale containing Inoceramis shell fragnents are present from about 5,750 to $7,100 \mathrm{ft}(1,753$ to $2,164 \mathrm{~m})$.

Turonian $(7,440-8,230 \mathrm{ft} ; 2,268-2,508 \mathrm{~m})$

Samples from 7,440 ft $(2,268 \mathrm{~m})$ and below contain the shallow-water elements described above, In addition to gray calcarenus shale cuttings of Turonian age. The Turonian shale is recognized by the co-occurrence of Corollithion achylosum and Eiffellithus eximius. The two uppermost Turonian samples from 7,440 to 7,450 ft $(2,268$ to $2,271 \mathrm{~m})$ and from 7,530 to $7,540 \mathrm{ft}$ $(2,295$ to $2,298 \mathrm{~m})$ are separated $\mathrm{l}$ several hundred feet of Campanian cavings from a sequence of Turonian samples that extends $430 \mathrm{ft}$ $(131 \mathrm{~m})$, from 7,770 to $8,200 \mathrm{ft}(2,369$ to 2,499 $\mathrm{m})$. If the top of the Turonian is indeed near $7,440 \mathrm{ft}(2,268 \mathrm{~m})$, the stage is about $760 \mathrm{ft}$ (232 m) thick.

These results differ somewhat from the findings of International Blostratigraphers, Inc. (1979) based on a study of calcareous nannofossils from sidewall cores. In that report, the top of the Turonian was placed at 8,140 ft $(2,481 \mathrm{~m})$, although Corollithion achylosum, a species restricted to Turonian and older rocks, was consistently present from 7,230 ft $(2,204 \mathrm{~m})$ down to $8,306 \mathrm{ft}(2,532 \mathrm{~m})$. Also, Eiffellithus eximius was not observed in sidewall cores below $7,044 \mathrm{ft}(2,14 i \mathrm{~m})$ or to occur with Corollithion achylosum (International Biostratigraphers, Inc., 1979). However, in the present study, Corollithion achylosum and Eiffellithus eximius are present together in individual rock chips from 7,440 tc $8,210 \mathrm{ft}$ 
$(2,268$ to $2,502 \mathrm{~m})$, and previous investigations have shown that the ranges of these two species overlap in the Turonian (Thierstein, 1976; Valentine, 1979). The base of the Turonian is placed at $8,230 \mathrm{ft}(2,508 \mathrm{~m})$ at a marked change in lithology from gray calcareous shale to coarse quartz sand that predominates down to 8,700 ft $(2,652 \mathrm{~m})$. Turonian gray calcareous shale is present in the COST No. B-2 well from 7,100 to about $7,600 \mathrm{ft}(2,164$ to $2,316 \mathrm{~m})$.

\section{Cenomanian $(8,230-8,900 \mathrm{ft} ; 2,508-2,713 \mathrm{~m})$}

The Cenomanian is represented by a 670-ft (204-m) interval of quartz sandstone containing a minor amount of calcareous shale. The abrupt lithologic change at $8,230 \mathrm{ft}(2,508 \mathrm{~m})$ from calcareous shale to friable, coarse quartz sandstone may represent an unconformity between strata of Turonian and Cenomanian age. Samples from the upper $200 \mathrm{ft}(61 \mathrm{~m})$ of this part of the section are barren of calcareous nannofossils or contain Campanian and Turonian cavings. International Biostratigraphers, Inc. (1979, fig. 1) placed the top of the Cenomanian at the highest occurrence of Rotalipora cushmani in a sidewa11 core from $8,040 \mathrm{ft}(2,451 \mathrm{~m})$, slightly above the top of the sandstone. According to their interpretation, the lithologic change from shale to sandstone is in the upper part of the Cenomanian interval. Shale cuttings from the lower part of the Cenomanian, as delineated in the present study, exhibit the highest occurrences of cruciellipsis chiastia, Parhabdolithus asper, and Podorhabdus albianus, whereas Eiffellithus eximius, a species restricted to Turonian and younger beds, is not present.

\section{Albian $(8,900-9,840 \mathrm{ft} ; 2,713-2,999 \mathrm{~m})$}

The top of the Albian is recognized at $8,900 \mathrm{ft}(2,713 \mathrm{~m})$, the highest occurrence of Braarudosphaera africana (p1. 2, fig. 12), a species that ranges from the upper Aptian through the Albian (Gartner, 1977). Albian strata are chiefly calcareous shales and barren calcareous sandstones. The nannoflora found in the shale cuttings is relatively diverse and Includes Braarudosphaera africana, Corollithion signum, Cruciellipsis chiastia, Flabellites biforaminis (p1. 1. f1gs. 5, 6), Parhabdolithus asper, Prediscosphaera cretacea, and nannoconids. The lowest occurrence of Prediscosphaera cretacea is at 9,840 ft $(2,999$ $\mathrm{m})$ and approximates the base of the Albian Stage.

$$
\begin{gathered}
\text { Aptian-Barremian }(9,840-11,018 \mathrm{ft} ; \\
2,999-3,358 \mathrm{~m})
\end{gathered}
$$

In contrast to the overlying Albian strata, the Aptian-Barremian interval is a very poorly fossiliferous sequence of calcareous sandstone and shale about $1,178 \mathrm{ft}(359 \mathrm{~m})$ thick. Most samples examined are almost barren except for some shale cuttings containing nannofloras of Aptian-Albian aspect that include such species as Braarudosphaera africana, Chiastozygus plicatus, Corollithion achylosum, Cretarhabdus coronadventis, Cmuciellipsis chiastia, Flabellites biforaminis, Lithastrinus fioralis, Micrantholithus obtusus (p1. 2, fig. 10), Parhabdolithus angustus, and $P$. infinitus (p1. 1, fig. 1). A conventional core and a series of seven sidewall cores from 9,935 to $10,730 \mathrm{ft}$ $(3,028$ to $3,270 \mathrm{~m})$ are barren of calcareous nannofoss11s (International Blostratigraphers, Inc., 1979). Consequently, the Barremian and Aptian cannot be differentiated, and the upper and lower boundaries of the Barremian-Aptian part of the well are provisional.

$$
\begin{aligned}
& \text { Hauterivian-Valanginian }(11,018-12,700 \mathrm{ft} \text {; } \\
& 3,358-3,871 \mathrm{~m})
\end{aligned}
$$

Hauterivian and Valanginian strata also cannot be differentiated using calcareous nannofossils. They are calcareous sandstone and shale, somewhat more fossiliferous than the overlying Aptian and Barremian beds. The abundance of calcareous nannofossils varies from few to common, and preservation is poor to moderate. The top of the approximately 1,682-ft (513-m) Hauterivian-Valanginian sequence is drawn at the highest occurrence of Bipodorhabdus colligatus (p1. 1, figs. 8, 9), observad in a conventional core sample from $11,018 \mathrm{ft}(3,358$ $\mathrm{m})$; and calcareous nannofossil assemblages of the same age were identified in three other conventional core samples from $11,029 \mathrm{ft}(3,362$ $\mathrm{m}), 11,044 \mathrm{ft}(3,366 \mathrm{~m})$, and $11,045 \mathrm{ft}(3,367 \mathrm{~m})$ (International Biostratigraphers, Inc., 1979).

The following species are typically present In calcareous shale from this interval: Bipodorhabdus colligatus, Diazomatlolithus Zehmanii, Conusphaera mexicana (pl. 2, fig. 3), Cruciellipsis chiastia, C. cuvillieri (p1. 1, f1gs. 11, 12), Cyclagelosphaera deflandrei (pl. 1, fig. 10), C. margerelii (p1. 1, fig. 7), Micrantholithus obtusus, Nannoconus colorii (p1. 1, figs. 2, 3), Parhabdolithus asper, $P$. embergeri, Watznaueria barnesae, $W$. communis (p1. 1, fig. 4), Zygodiscus diplogramm's, and unidentified nannoconids. In the lower part of the Hauterivian-Valanginian, a small species of Micrantholithus (p1. 2, fig. 13) was observed in only one sample $(12,590-12,600 \mathrm{ft} ; 3,8: 7-3,840$ m) In the $\operatorname{cosT}$ No. B-3 we11; it resembles Micrantholithus sp. reported from the Bossier Shale of Late Jurassic-Early Cretaceous age in Loulsiana and Arkansas by Cooper and Shaffer (1976, pl. 1, fig. 4). A distinctive species, Bidiscus? canthus (p1. 2, flg. 4), is present in three samples from a short stratigraphic interval $(12,470-12,740 \mathrm{ft} ; 3,801-3,883 \mathrm{~m})$ that extends from the lower part of the HauterivianValanginian into the upper part of the Berrlasian.

An interval of varied 1ithology is present from about 12,400 to 12,700 ft $(3,780$ to 3,871 
m). As described by Lachance (1979), this part of the section is composed of calcareous sandstone and gray shale and shallow-water oolitic and intraclastic limestone containing algal structures. The shale cuttings from this interval yielded calcareous nannofossil assemblages of Hauterivian-Valanginian age, whereas the limestone and calcareous sandstone cuttings are barren. The isolated occurrence of the Berriasian marker Polycostella senaria in a sidewall core from 12,394 ft $(3,778 \mathrm{~m})$ (International Biostratigraphers, Inc., 1979) casts some doubt on the Hauterivian-Valanginian age of the lower part of this interval, although its presence may have resulted from reworking or contamination, as will be discussed later. At present, the beds from 12,400 to $12,700 \mathrm{ft}$ $(3,780$ to $3,871 \mathrm{~m})$ are included in the lower part of the Hauterivian-Valanginian sequence, and are interpreted as representing deposition in a shallow-water marine environment.

Berriasian $(12,700-13,450 \mathrm{ft} ; 3,871-4,100 \mathrm{~m})$

On the basis of the study of calcareous nannofossils in individual rock chips from cuttings samples, the top of the Berriasian interval should be placed at $12,700 \mathrm{ft}(3,871$ $\mathrm{m})$, the level of highest occurrence of Polycostella senaria (pl. 2, figs. 7-9) and somewhat below both the lowest occurrence of Bipodorhabdus colligatus $(12,640 \mathrm{ft} ; 3,853 \mathrm{~m})$ and the point at which the $95 / 8-1$. casing was set $(12,659 \mathrm{ft} ; 3,858 \mathrm{~m})$. Polycostella senaria is restricted to strata of Berriasian age (Thierstein, 1973), and Bipodorhabdus colligatus does not range below the Valanginian (Thierstein, 1976). International Blostratigraphers, Inc. (1979), in a study of sidewall cores, reported the highest occurrence of Polycostella senaria from 12,394 ft (3,778 m) and the lowest occurrence of Bipodorhabdus colligatus from $12,510 \mathrm{ft}(3,813 \mathrm{~m})$. The same study showed, however, that Polycostella senaria is consistently present in a series of four sidewall cores from 12,734 to 12,903 ft $(3,881$ to $3,933 \mathrm{~m})$, and the authors speculated that its isolated presence $340 \mathrm{ft}(104 \mathrm{~m})$ above this group of samples could be the result of reworking.

Between the casing point $(12,659 \mathrm{ft} ; 3,858$ $\mathrm{m})$ and $13,400 \mathrm{ft}(4,084 \mathrm{~m})$, the cuttings are almost free of caved younger material and are composed of dark-gray calcareous shale of Berriasian age. Calcareous nannofossils are rare to few in number, and preservation is poor to moderate. Assemblages found in the shale comprise Brachiolithus? sp. (p1. 2, figs. 1, 2), Cruciellipsis chiastia, Cyclagelosphaera deflandrei, C. margerelii, Polycostella senaria, Watznaueria bamesae, W. communis, and nannoconids. The species questionably assigned to Brachiolithus (Noel, 1959, pl. 3, figs, 2527) Is a common constituent of the Berriasian assemblages; it is restricted to strata of that age in the COST No. B-3 well and may prove to be of biostratigraphic importance. Nearly barren cuttings of uncertain age are present in samples from $13,420 \mathrm{ft}(4,090 \mathrm{~m})$ and deeper, but the Berriasian dark-gray shale, presumably cavings, remains a prominent constituent of samples down to about $14,000 \mathrm{ft}(4,267 \mathrm{~m})$.

$$
\begin{gathered}
\text { Upper Jurassic }(13,450-15,800 \mathrm{ft} \text {; } \\
4,100-4,816 \mathrm{~m})
\end{gathered}
$$

The Jurassic-Lower Cretaceous bcindary in the $\cos T$ No. B-3 well is provisionally placed at $13,450 \mathrm{ft}(4,100 \mathrm{~m})$ the highest occurrence of Polycostella beckmannii (pl. 2, fig. 6). This spectes is reported to range from the Tithonian (=Portlandian) into the lower Berriasian, where it is associated with $P$. senaria (T'ierstein, 1973, 1976; Gartner, 1977), and the two species are found together in individual chips of calcareous shale from 13,450 to $13,940 \mathrm{ft}(4,100$ to $4,249 \mathrm{~m})$. However, undated cuttings of calcareous sandstone and shale that are almost barren are also present from about $13,420 \mathrm{ft}$ $(4,090 \mathrm{~m})$; they become more prevalent with increasing depth and may be of Jurcssic age. The shale cuttings containing both Polycostella beckmannii and $P$. senaria may therefore be cavings from lowermost Berriasian strata somewhat higher in the well.

In the study by Internationa 1 Biostratigraphers, Inc. (1979) of calcareous nannofossils from the COST No. B-3 we11 sidewall cores, $P$. beckmannii and $P$. senamia were not observed in the same samples, and the JurassicLower Cretaceous boundary was placed in the interval between the lowest occurrence of $P$. senaria at $12,903 \mathrm{ft}(3,933 \mathrm{~m})$ and the highest occurrence of $P$. beckmannii at $13,758 \mathrm{ft}(4,193$ m).

There is no consensus on the placement of the Jurassic-Lower Cretaceous boundary in the CosT No. B-3 we11. International Biostratigraphers, Inc. (1979) concluded that foraminifers are not diagnostic (although Poag, this volume, disagrees), and the biostratigraphic significance of the range of a palynomorph species (Ctenododinum panneum) is disputed by palynologists who have worked on offshore wells of the Atlantic margin. According to Bujak and Williams (1977), $C$. panneum is restricted to the Jurassic. On this basis Steinkraus (1979) and J. I. Bebout (written communication, 1979) have drawn the Jurassic-Lower Cretaceous boundary at 12,400 ft $(3,780 \mathrm{~m})$, and Poag (this volume) arrees with this interpretation on the basis of his study of benthic foraminifers.

Steinkraus (1979) pointed out that in many of the Atlantic offshore wells the highest occurrences of $C$. panneum and the nannofossil Hexalithus noelae often coincide, and he also stated that $H$. noelae is not known to range above the Upper Jurassic. Cooper ard Shaffer (1976) studied the stratigraphic distribution of $H$. noelae in the Bossier Shale of the Arkansas 
and Louisiana subsurface and discussed the variant forms of the spectes as described by Noel $(1957,1959)$. [The species was described as Hexalithus hexalithus by Noel (1957) from the Portlandian of Algeria and renamed by Loeblich and Tappan (1966)]. Cooper and Shaffer (1976) concluded that the extinction level of this species approximates the top of the Jurassic; although they did not present an occurrence chart, they imply that $H$. noelae in the Bossier Shale is assoctated with, among others, Braarudosphaera bigelowii, Micrantholithus sp., Nannoconus colomii, Polycostella beckmannii, $P$. senaria, and Watznaueria brittanica. According to Thiersteln $(1973,1976)$, Polycostella senaria and Nannoconus colomii are restricted to Berriasian and younger rocks, and Polycostella beckmannii is found only in the Tithontan and Berriasian. Thus, the assemblage described by Cooper and Shaffer (1976) has a Berriasian aspect, and their evidence for the restriction of Hexalithus noelae to Tithonian and older strata is not compelling. Hexalithus noelae, as illustrated by Noel (1957, p1. 5, figs. 39, 40; 1959, pl. 3, fig. 24), was not observed in the present study. But a circular form with prominent sutures (p1. 2, fig. 5), very similar to $H$. noelae of Cooper and Shaffer (1976, pl. 1 figs, 6,7$)$, is present in one sample $(12,020-$ $12,030 \mathrm{ft} ; 3,664-3,667 \mathrm{~m})$ from the HauterivianValanginian part of the section in the COST No. B-3 we11.

International Biostratigraphers, Inc. (1979) interpreted the palynomorph Ctenododinum panneum as ranging from the Jurassic into the Lower Cretaceous where it is found with Pseudoceratium pelliferum, a Cretaceous dinoflagellate species. Therefore, at the COST No. B-3 well site, International Biostratigraphers, Inc. (1979) placed the Jurassic-Lower Cretaceous boundary in the interval from 12,900 to 13,650 ft $(3,932$ to $4,161 \mathrm{~m})$, the interval in which the ranges of the two species overlap.

To the north, at the CosT No. B-2 well site, the Jurassic-Lower Cretaceous boundary is at about 12,800 ft $(3,901 \mathrm{~m})$. In a revised interpretation of the blostratigraphy of the lower part of the $\operatorname{cosT}$ No. B-2 we11, W. W. Fairchild (International Blostratigraphers, Inc., written communication, 1977) provistonal1y placed the Jurassic-Lower Cretaceous boundary between 12,800 and $13,000 \mathrm{ft}(3,901$ and $3,962 \mathrm{~m})$ on the basis of the following observations: Polycostella senaria, the Berriasian nannofossil marker, is present in sidewall cores from 12,120 ft $(3,694 \mathrm{~m})$ and $12,365 \mathrm{ft}(3,769 \mathrm{~m})$; and the Cretaceous dinoflagellate Pseudoceratium pelliferum, mentioned above, is present in samples from $12,301,12,561$, and $12,791 \mathrm{ft}$ $(3,749,3,829$, and $3,899 \mathrm{~m})$. Ctenododinum panneum, a Jurassic-Cretaceous palynomorph, is present in the same interval and in sidewall cores up to $12,037 \mathrm{ft}(3,669 \mathrm{~m})$. In contrast, the Jurassic dinoflagellate Meiourogonyaulax staffinensis is present in sidewall cores and conventional cores from $12,791 \mathrm{ft}(3,899 \mathrm{~m})$ down to $13,448 \mathrm{ft}(4,099 \mathrm{~m})$. The Jurassic-lower Cretaceous contact is, therefore, near the $12,800-f t(3,901-m)$ level in the COST No. B-2 well, about $650 \mathrm{ft}(198 \mathrm{~m})$ higher than it is in the CosT No. B-3 we11. On the other land, Adinolfi and Jacobson (-1979) and Poag (1979, and this volume) placed the top of the Jurassic between 11,800 and $12,000 \mathrm{ft}(3,597$ and $3,658 \mathrm{~m})$ in the COST No. B-2 well on the basis of benthic foraminifers and palynomorphs.

In the COST No. B-3 well, calcareous nannofossils are rare and poorly preserved $1 \geq 1$ low about 14,000 ft $(4,267 \mathrm{~m})$; only long-raroing species such as Cyclagelosphaera margereli $i$ and Watznaueria barnesae are present. Calcareous nannofossil assemblages of Jurassic age were not recognized in this analysis or by International Biostratigraphers, Inc. (1979), but the presence of palynomorphs of Kimmeridgian age in the part of the well below $13,220 \mathrm{ft}(4,029 \mathrm{~m})$ has been reported by Steinkraus (1979) and J. W. Bebout (written communication, 1979), and below about 13,700 ft $(4,176 \mathrm{~m})$ by Internationa 1 Biostratigraphers, Inc. (1979). Poag (this volume) recognized benthic foraminifers of early and late Kimmeridgian age and possibly of Callovian age.

\section{PALEOENVIRONMENTS}

The paleoenvironmental interpretatior of the $\operatorname{cosT}$ No. B-3 well section presented here (fig. 30) is based on the abundance, diversity, and generic composition of calcareous nannofossil and ostracode assemblages; on the presence and abundance of diatoms; and on the lithologic characteristics of the sedimertary strata. Paleoenvironmental reconstructions based on studies of benthic and planktic foraminifers and of sporomorphs and dinoflagelJates (International Blostratigraphers, Inc. 1979; Bebout and Lachance, 1979; Poag, this volime), and the abundance of terrestrial palynomcrphs (Bebout and Lachance, 1979, fig. 5) have also been considered. Depositional environments are characterized in terms of shelf and slope denths as they generally exist today. However, references to slope depths do not necessarily mean that deposition took place on an ancient slope, for it may well have occurred on a shelf or platform that lay at a depth greater than modern shelves (greater than about $650 \mathrm{ft}$ or 200 m). The trends 11lustrated in figure 30 are real, but because the results of this analysis are general in nature, the degree of their development is not yet known precisely.

Upper Jurassic strata are present in the CosT No. B-3 well from total depth of the well at $15,820 \mathrm{ft}(4,822 \mathrm{~m})$ to $13,450 \mathrm{ft}(4,107 \mathrm{~m})$ and comprise a $2,370-\mathrm{ft}(722-\mathrm{m})$ sequence of interbedded oolitic limestone, sandstone, carkgray shale, and 1ignite. Below about $14,0 \mathrm{CO} \mathrm{ft}$ $(4,267 \mathrm{~m})$, these rocks are almost barren of calcareous nannofossils; foraminiferal feunas 
are also very sparse below $14,500 \mathrm{ft}(4,420$ $\mathrm{m})$. The lithology of the sedimentary beds and the nature of the fossil assemblages indicate that this part of the Upper Jurassic was probably deposited in fluctuating nonmarine and shallow-marine environments.

From 14,000 ft $(4,267 \mathrm{~m})$ to the JurassicLower Cretaceous boundary at $13,450 \mathrm{ft}(4,100$ $\mathrm{m})$, the strata were deposited in a somewhat deeper-marine middle-shelf environment. The calcareous nannofossil assemblages are not diverse, but the few species are consistently present throughout the interval.

A marine middle-shelf environment continued to prevall throughout Berriasian time, and calcareous nannofossil assemblages became more diverse. The Berriasian rocks (13,450-12,700 ft; $4,100-3,871 \mathrm{~m}$ ) are primarily marine shale and sandstone with a minor amount of limestone.

At the base of the Hauterivian-Valanginian, a 300-ft (91-m) interval from 12,700 to 12,400 ft $(3,871$ to $3,780 \mathrm{~m})$ is chiefly shale and sandstone interbedded with oolitic limestone indicative of a shallow-marine origin. Terrestrial palynomorphs increase in abundance in these strata and subsequently decline in number with the return of middle-shelf, silty and sandy shale that extends up to about 12,000 ft $(3,658 \mathrm{~m})$ and contains fairly diverse calcareous nannofoss 11 assemblages.

The upper part of the HauterivianValanginian, from $12,000 \mathrm{ft}$ to about $11,000 \mathrm{ft}$ $(3,658$ to $3,353 \mathrm{~m})$, is sparsely fossiliferous with regard to both calcareous nannofossils and foraminifers. The silty shale, sandstone, and minor coal beds of this interval were deposited in an inner shelf environment.

At the Hauterivian-Barremian boundary $(11,018 \mathrm{ft} ; 3,358 \mathrm{~m})$, a very thin sequence of shale $(11,046-10,930 \mathrm{ft} ; 3,367-3,331 \mathrm{~m})$ marks the return of middle-shelf conditions. Calcareous nannofossils and foraminifers are present, and terrestrial palynomorphs decline in abundance.

The overlying Aptian-Barremian strata $(10,930-9,840 \mathrm{ft} ; 3,331-2,999 \mathrm{~m})$ are almost barren of calcareous nannofossils, and foraminifers are mostly absent from about 10,700 to 10,400 ft $(3,261$ to $3,170 \mathrm{~m})$, except near the top of the interval. The sandstone, shale, and minor lignite present in the sequence were deposited in a nonmarine to inner shelf environment.

The Albian beds $(9,840-8,900$ ft; 2,999$2,713 \mathrm{~m})$ are chiefly silty shale with several interbedded sandstone layers; they reflect a modest increase in water depth to inner shelf conditions. Calcareous nannofossils and foraminifers are present in some samples, although others are barren. Terrestrial palynomorphs are abundant, perhaps indicating an increase in terrigenous sedimentation.

Water depth continued to increase, and the silty shale that is present in the lower part of the Cenomanian $(8,900-8,460 \mathrm{ft} ; 2,713-2,579 \mathrm{~m})$ reflects a middle-shelf environment. Diverse calcareous nannofossil assemblages are present in this interval, and terrestrial palynomorphs increase markedly in abundance. The upper part of the Cenomanian $(8,460-8,230 \mathrm{ft} ; 2,579-2,509$ $\mathrm{m})$, however, is composed of coarse quartz sand and is barren of calcareous nannofossils. Also, terrestrial palynomorphs increase in abundance and Indicate that the sand was derosited in an inner shelf environment.

A disconformity exists in the COST No. B-3 well section at $8,230 \mathrm{ft}(2,509 \mathrm{~m})$; marks a hiatus between Cenomanian shallow-rater deposits and middle to upper Turonian calcareous shale of outer shelf origin that extends u? to $7,440 \mathrm{ft}$ $(2,268 \mathrm{~m})$. Calcareous nannofossils are diverse, and terrestrial palynomorphs decline in abundance in this interval.

At the top of the Turonian, another disconformity coincides with a shallowing of the marine environment to inner shelf conditions during the Confacian. Marine sand and silt containing lignite, mica, large pyrite crystals, and shell fragments of shallow-marine mollusks were deposited from $7,440 \mathrm{ft}$ to about $7,040 \mathrm{ft}$ $(2,268$ to $2,146 \mathrm{~m})$. Calcareous narnofossils are poor1y represented in this part of the section. However, they increase in abundance and diversity in the overlying Santonian glaucontic sandstone of middle-slelf to outer shelf origin that is present from 7,040 to 6,470 ft $(2,146-1,972 \mathrm{~m})$. Terrestrial palynomorphs reach a maximum abundance in the Coniacian interval and decline in numbers with deepening marine conditions in in the Santonian.

The overlying Campanian and Maestrichtian calcareous shale that is present from 6,470 to $6,040 \mathrm{ft}(1,972$ to $1,841 \mathrm{~m})$ is rich in calcareous nannofossils and foraminifers, but poor in terrestrial palynomorphs. A marine environment characterized by outer shelf to upper slope depths developed at the COST No. B-3 well site during the Campanian and Nastrichtian. Ostracode assemblages indicativs of these conditions are also present; they are sparse, exhibit low diversity, and are composed chiefly of the genera Alatacythere, Bairdia, Bythocytheremorpha, Cytherella, Krithe, and Phacorhabdotus.

A major disconformity is present at 6,040 ft $(1,841 \mathrm{~m})$ between lower Maestrichtian calcareous slitstone and lower Eocene limestone. The thick limestone sequence from 6,040 to $4,950 \mathrm{ft}(1,841$ to $1,509 \mathrm{~m})$ encompasses lower, middle, and upper Eocene strata that contain very rich calcareous nannofossil and foraminifer assemblages. Terrestrial palynomorphs are absent, and ostracodo assemblages throughout the Eocene are dominatel by Bairdia, Cytherella, Krithe, Eckinocythereis, Henryhowelia, Phacorhabdotus, and Pterygocythereis. All evidence points to deposition of the Eocene limestone at upper slope water depths, somewhat deener and more 
isolated from terrigenous sediments than postulated for Campanian and Maestrichtian strata.

The upper Eocene limestone is overlain disconformably by middle and upper oligocene calcareous and diatomaceous mudstone that extends from 4,950 to $4,710 \mathrm{ft}(1,509$ to 1,436 m). Calcareous nannofossils are abundant and diverse, and ostracode assemblages in these beds are similar in generic composition to those found in the underlying Eocene. The Oligocene rocks were deposited at upper slope depths similar to those of the Eocene paleo. environment. The sedimentary regime had altered significantly, however, as indicated by the presence of an increased volume of terrigenous particles in the oligocene rocks.

The upper oligocene is succeeded disconformably by middle Miocene diatomaceous siltstone and mudstone. These beds are less calcareous than those of the oligocene and also contain a less diverse calcareous nannofossil flora. Even though terrestrial palynomorphs are abundant, their presence here reflects the continuation of a sedimentary regime characterized by an influx of terrigenous sediments rather than a decrease in water depth. The middle Miocene at the $\cos T$ No. $B-3$ well site was a time of rapid terrigenous sedimentation in an upper slope environment of deposition.

Pliocene and Quaternary silt and clay are probably present at the COST No. B-3 well site in the upper part of the unsampled interval between the sea floor $(2,728 \mathrm{ft} ; 831 \mathrm{~m})$ and $3,810 \mathrm{ft}(1,161 \mathrm{~m})$. At least $1,000 \mathrm{ft}(305 \mathrm{~m})$ of pleistocene silt and clay of outer shelf to upper slope origin have been cored at AMCOR site 6021 on the uppermost Continental slope, about 4 $\mathrm{mi}(6 \mathrm{~km}$ ) northwest of the $\operatorname{cosT}$ No. B-3 well; and sand and silt of Miocene, P1locene, and Pleistocene age have been cored at AMCOR site 6010 on the Continental Shelf, about $21 \mathrm{mi}$ (33 $\mathrm{km}$ ) to the northwest (Hathaway and others, 1979).

In summary, the stratigraphic section drilled at the CosT No. B-3 site comprises chiefly marine clastic and carbonate strata ranging in age from Late Jurassic to Quaternary. In Late Jurassic time, nonmarine to inner shelf environments prevailed, whereas the Early Cretaceous is best characterized as a time during which marine environments fluctuated between Inner shelf and middle-shelf depths. Middle-shelf conditions existed during deposition of the following stratigraphic intervals: the uppermost Jurassic and the Berriasian, the lower part of the HauterivianValanginian, the Hauterivian-Valanginian boundary, and the lower part of the Cenomanian. Major unconformities are not discernible in the Upper Jurassic and Lower Cretaceous, although the poorly fossiliferous nature of the shallow-marine and marginally nonmarine intervals may mask hiatuses in this section.
The middle-shelf environment of deposition in the lower part of the Cenomanian preceded a major regression, also in the Cenomanian, when quartz sand was deposited in an innermost shelf environment. These beds are separ-ated by an unconformity from the overlying transgressive calcareous shale of middle to late Turonian age that was deposited at outer shelf denths. Subsequent1y, another regression occurred, and Coniacian sand and silt indicative of an inner shelf facies accumulated disconformably on the Turonian shale.

During Coniacian through Maestrichtian time, a major transgression developed, and the marine environment gradually deepened from inner shelf depths in the Confacian to a middle--shelf and outer shelf environment during deposition of the Santonian glauconitic sand. Firally, Campanian and Maestrichtian calcareous shale accumulated at outer shelf and upper slope depths.

The Maestrichtian and lower Eocene strata are separated by a disconformity that may nark a marine regression, although no shallow-water deposits are present in this part of the COST No. B-3 well section. The limestone of the lower Eocene is indicative of deposition at upper slope depths that are also recorded in the overlying beds of Eocene, 01igocene, and Mrocene age that were sampled during the drilling of the we11.

Two other disconformities are present in the Tertiary part of the section, for both the lower 0ligocene and lower Miocene are missing. There is no indication, however, of significant shallowing of the marine environment associated with these two hiatuses in the stratigraphic record.

As the flux of both terrigenous sediments and nutrients increased in post-Eocene time, the Eocene limestone gave way to calcareous and diatomaceous mudstone and siltstone that accumulated rapidly during the oligocene and especially in Miocene time. The increase in nutrients, as demonstrated by the presence of rich diatom floras, was directly related to the increase in terrigenous sedimentation and (or) upwelling on the Continental slope. Given the results of the limited shallow coring that has taken place on the upper slope of this region and the present water depth $(2,686 \mathrm{ft} ; 819 \mathrm{~m})$ at the drill site, it is evident that an upper slope environment has existed at the COST No. B3 well site throughout Neogene and Quaternary time.

\section{POST-JURASSIC MARGIN DEVELOPMENT}

The post-Jurassic developmental history of the Continental Margin at the COST No. B-3 well site can be elucidated by comparing the average sediment-accumulation rates, the average subsidence rates, and the depositional depths of the stratigraphic intervals represented in the section. 
Sediment accumulation rates for three major intervals in the COST No. B-3 well section are $1.56 \mathrm{in} \cdot / 1,000$ yrs $(3.96 \mathrm{~cm} / 1,000 \mathrm{yrs})$ for the Lower Cretaceous, 0.98 in./1,000 yrs (2.49 $\mathrm{cm} / 1,000 \mathrm{yrs}$ ) for the Upper Cretaceous, and 0.61 in. $/ 1,000$ yrs $(1.55 \mathrm{~cm} / 1,000 \mathrm{yrs})$ for the Cenozolc. Hiatuses contribute significantly to the low accumulation rate calculated for the Cenozoic part of the section. Separate determinations for the Eocene, upper Oligocene, and middle Miocene Intervals give accumulation rates of $0.87 \mathrm{in} . / 1,000$ yrs $(2.21 \mathrm{~cm} / 1,000 \mathrm{yrs})$, $0.44 \mathrm{in} . / 1,000$ yrs $(1.11 \mathrm{~cm} / 1,000 \mathrm{yrs})$, and 2.57 1n. $/ 1,000$ yrs $(6.52 \mathrm{~cm} / 1,000$ yrs $)$, respectively.

Subsidence rates for the lower surfaces of these stratigraphic intervals are more difficult to determine. Factors that must be considered include the thickness of the strata, compaction, the depths at which the lower and upper surfaces of the unit were deposited, and the positions of sea level (relative to present sea level) at the beginning and end of deposition of the unit. (For method of calculation, see van Hinte, 1978; Poag and Ha11, 1979.) The effect of compaction was disregarded in the present study. Paleodepths remained at about $300 \mathrm{ft}(100 \mathrm{~m})$ for the lower and upper surfaces of the Lower Cretaceous, but increased from 300 to $1,000 \mathrm{ft}$ $(100$ to $300 \mathrm{~m})$ for the Upper Cretaceous and from $1,000 \mathrm{ft}(300 \mathrm{~m})$ to $2,686 \mathrm{ft}(819 \mathrm{~m}$; present-day water depth) for the Cenozoic. Subsidence rates are based on these estimates, as well as on the sea-level projections of Vall and others (1977, fig. 6c) and, alternatively, on the assumption that sea level was always at its present level. Even though this conservative approach has generated a spread of values for the subsidence rate of each stratigraphic interval, the general depositional history has not been obscured. The calculations using sea levels postulated by Vail and others (1977) resulted in the lowest values for Lower and Upper Cretaceous subsidence rates and the highest values for the Cenozoic subsidence rate.

The Lower Cretaceous subsidence rates vary from 1.17 to $1.56 \mathrm{In} / 1,000$ yrs (2.96 to 3.96 $\mathrm{cm} / 1,000$ yrs), generally lower than the accumulation rate of $1.56 \mathrm{in} . / 1,000$ yrs $(3.96$ $\mathrm{cm} / 1,000 \mathrm{yrs})$. The Upper Cretaceous subsidence rates range from 0.99 to $1.20 \mathrm{in} . / 1,000$ yrs (2.51 to $3.06 \mathrm{~cm} / 1,000 \mathrm{yrs})$, somewhat higher than the accumulation rate of $0.98 \mathrm{in} \cdot / 1,000$ yrs $(2.49 \mathrm{~cm} / 1,000 \mathrm{yrs})$. In contrast, subsidence rates calculated for the Cenozolc interval range from 0.93 to $1.12 \mathrm{ln} . / 1,000$ yrs $(2.35$ to 2.85 $\mathrm{cm} / 1,000 \mathrm{yrs})$, consistently much higher than the overa11 sediment accumulation rate of 0.61 in./1,000 yrs $(1.55 \mathrm{~cm} / 1,000$ yrs $)$.

The post-Jurassic geologic evolution of the Continental Margin in this region is summarized as follows: Lower Cretaceous sediments accumulated rapidly, and water depth fluctuated within a narrow range characteristic of shelf conditions (although, according to vail and others (1977, fig. 6c), sea level rose throughout the Early Cretaceous). During Late Cretaceous time, the subsidence rate was somewhat higher than the sediment-accumulation rate, and sediments were deposited at shelf and, later, uppermost slope depths coincident with a continued rise and stabilization of sea level (Vail and others, 1977, fig. 6c). In general, during the Cretaceous, rapid accumulation of sediments, relatively rapid subsidence, and rising sea level all contributed to the aggradation or upbuilding of the middle Atlantic Continental Margin off New Jersey. If a Continental Slope existed, it was seaward of the CosT No. B-3 well site.

In Cenozoic time, the rate of subsidence and (or) sediment removal was, on the average, much greater than the rate of sediment accumulation. As mentioned above, the calculated sediment accumulation rate may be somewhat low due to hlatuses in the record. The Continental Margin near the CosT No. B-3 well site subsided to water depths characteristic of the present slope, but seismic profiles of the margin in this region (Grow and others, 1979, figs. 4, 5) show that an obvious shelf-slope break did not exist landward of the COST No. B-3 well until post-0ligocene time. During the Eocene and 0ligocene, the broadly subsiding Continental Margin was built upward by a substantial thickness of predominantly carbonate sediments that included an increased amount of terrigenous debris in the 0ligocene. Slope water depths have been maintained by subsidence at the COST No. B-3 we11 to the present time, even though VaIl and others (1977, fig. 6c) have indicated that sea level, while fluctuating above and below its present level, has fallen throughout the cenozoic. It is not yet clear whether the Paleocene, lower and middle oligocene, and lower Miocene hiatuses are the result of subaerial or submarine erosion or nondeposition. No evidence exists of shallowwater sediments bounding these hiatuses in the CosT No. B-3 well section.

Subsidence continued throughout postoligocene time, but the margin became progradational; it evolved primarily by outbuilding or progradation through the rapid deposition of a large volume of terrigenous sediment. Prograding beds of probable Miocene age are clearly visible in seismic profiles of the shelf in this area (Schlee and others, 1976, figs. 7, 8, 9; Amato and Simonis, 1979, p1. 5; Schlee and Grow, this volume). The edge of the present Continental Shelf was therefore defined by the prograding post-0ligocene sedimentary wedge, and the Continental Rise developed as an onlapping sequence of deep-water sediments that were derived from erosion of both the land surface and the newly developed Continental slope.

\section{TAXONOMIC NOTES}

The following remarks refer to several of the calcareous nannofossil species illustrated in plate 2 . 
Brachiolithus? sp. (p1. 2, figs. 1, 2) is restricted to the Berriasian interval in the CosT No. B-3 well and is present from 12,700 to 13,240 ft $(3,871$ to $4,036 \mathrm{~m})$. This apparently undescribed spectes is hexagonal or septagonal, having an open center and six or seven short, rectangular, lateral spines that radiate from the corners of the rim. The outside diameter of the rim is $5.0-6.5 \mu \mathrm{m}$, and including the spines, $6.0-7.5 \mu \mathrm{m}$. The width of both the rim wall and spines is $0.7-1.0 \mu \mathrm{m}$. Brachiolithus? species somewhat resembles three species of the genus Brachiolithus Loeblich and Tappan that have been observed in the Portlandian, Berriasian, and Valangintan of Algeria (Noel, 1959, pl. 3, figs. 25-27). However, Brachiolithus? sp. of the COST No. B-3 well is smaller, the central area is open, and the species does not appear to be formed by a single crystal of calcite as is Brachiolithus. It is not possible to determine using the light microscope whether the rim of Brachiolithus? sp. is segmented. Brachiolithus? sp. also resembles Stephanolithion sp. of Bukry and Bramlette (1969, p1. 4B), a species observed in a core-catcher sample from the bottom of DSDP Hole 5A that was dated as Tithonian (=Portlandian) by those authors. Brachiolithus? sp. lacks the central spine and radiating bars of the central area that are characteristic of the described species of Stephanolithion from the Jurassic and Lower Cretaceous (Rood and Barnard, 1972).

Bidiscus? canthus W1lcoxon (p1. 2, fig. 4) is present in the Hauterivian-Valanginian and Berriasian intervals in the COST No. B-3 well from 12,470 to $12,740 \mathrm{ft}(3,801$ to $3,883 \mathrm{~m})$. This species was observed in the Valanginian, Hauterivian, and Barremian strata at DSDP sites 99 and 105 (Wilcoxon, 1972, p1. 6, figs. 5, 6). The specimen illustrated here (p1. 2, fig. 4) most resembles the specimen on Wilcoxon's plate 6 , figure 6 , but specimens similiar to the specimen on Wilcoxon's plate 6 , figure 5 were also observed and are included in $B$. ? canthus.

Hexalithus aff. $H$. noelae Loeblich and Tappan (p1. 2, fig. 5) was observed in a single sample in the COST No. B-3 we11 $(12,020-12,030$ ft, Hauterivian-Valanginian). This species is similar to $H$. noelae of Cooper and Shaffer (1976, pl. 1, figs. 6, 7) from the Bossier Shale of Loulstana, but $1 t$ differs from $H$. noelae Loeblich and Tappan in possessing a circular rather than the festooned or hexagonal outline exhibited by the forms originally illustrated by Noel (1957, pl. 5, figs. 39, 40; 1959, p1. 3, fig. 24). The extinction level of $H$. noelae of Cooper and Shaffer (1976) may not be a rellable datum for recognizing the Jurassic-Cretaceous (Tithonian-Berriasian) boundary.

Polycostella senaria Thierstein (p1. 2, flgs. 7-9), a Berriasian marker, is present from 12,700 to $14,120 \mathrm{ft}(3,871$ to $4,304 \mathrm{~m})$ in the $\operatorname{CosT}$ No. B-3 well, but occurrences below about $13,450 \mathrm{ft}(4,100 \mathrm{~m})$ are probably the result of caving. (See preceding text.) $P$. senaria, illustrated on plate 2, figure 7, displays seven ridges, and it is comparable to specimens 1llustrated by Thierstein (1971, pl. 1, fig. 6) and by Cooper and Shaffer (1976, pl. 1, fig. 3), both of which show a proximal view of a sevenpointed specimen. $P$. senaria specimens illustrated here in plate 2, figures 8,9 each display six points and six well-developed ridges, and they are comparable to distaJ. views of the holotype (Thierstein, 1971, p1. 1, figs. 2-5). The six-pointed specimens found in the CosT No. B-3 well are also similar to ?Hexalithus noelae? of Cooper and Shaffer (1976, p1. 1, fig. 2) from the Bossier Shale of Louisiana. And a comparison of the scanning electron micrographs of Polysoctella senaria (Thierstein, 1971, pl. 1, fig. 2) and ?Hexalithus noelae? of Cooper and Shaffer (1976, p1. 1, fig. 2) indicates that their similarity might be somewhat obscured by overgrowth on Thierstein's specimen. If these observations are correct, the specimen of ?H. noelae? illustrated by Cooper and Shaffer (1976, pl. 1, fig 2) is Polycostella senaria.

The pentaliths of Braarudosphaera eff. $B$. africana Stradner (p1. 2, fig. 11) are composed of elements that are relatively wide with a blunt distal termination, whereas in $B$. africana Stradner (pl. 2, fig. 12), the elements are relatively narrower and pointed. (Compare with Noel, 1959, p1. 9, fig. 47, from the All ian of

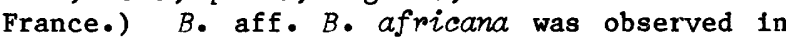
two Turonian samples (both are cavings collected from the Cenomanian interval: $8,260-8,270 \mathrm{ft}$ and $8,330-8340 \mathrm{ft} ; 2,518-2,521$ and $2,539-2,542$ $\mathrm{m})$ in the COST No. B-3 we11; and it is present higher in the section than $B$. africana, which is present from 8,900 to $9,830 \mathrm{ft}(2,712$ tc 2,996 m).

Micrantholithus sp. (p1. 2, fig. 13) is present in only one sample (HauterivianValanginian; $12,590-12,600 \mathrm{ft} ; 3,837-3,840 \mathrm{~m})$. This species resembles $M$. sp. of Coopor and Shaffer (1976, p1. 1, fig. 4) from the Bossier Shale of Louisiana. 
PLATE 1

Light micrographs (x2890) of selected nannofossils from the COST No. B-3 we11.

Figure 1. Parhabdolithus infinitus (Worsley) Thierstein, Sample 9,950-9,960

ft; R86N16A; crossed nicols, gray filter.

2-3. Nannoconus colomii (de Lapparent) Kamptner.

2. Sample 12,390-12,400 ft; R87N25A; crossed nicols, blue filter.

3. Same specimen; R87N26A; partly polarized light, blue filter.

4. Watznaueria communis Reinhardt, Sample 12,590-12,600 ft; R87N34A; crossed nicols, gray filter.

5-6. Flabelities biforaminis Thierstein.

5. Sample 10,240-10,250 ft; R87N18A; crossed nicols, gray filter.

6. Same specimen, rotated $45^{\circ}$; R87N19A; crossed nicols, gray filter.

7. Cyclagelosphaera margerelii Noe1, Sample 13,130-13,140 ft; R87N31A; crossed nicols.

8-9. Bipodorhabdus colligatus (Black) Thierstein.

8. Sample 12,390-12,400 ft; R87N23A; crossed nicols, gray filter.

9. Same specimen, rotated $28^{\circ}$; R87N24A; crossed nicols, gray filter.

10. Cyclagelosphaera deflandrei (Manivit) Roth, Sample 13,130-13,140 ft; R87N28A; crossed nicols, gray filter.

11-12. Cruciellipsis cuvillieri (Manivit) Thierstein.

11. Sample 12,020-12,030 ft; R87N21A; crossed nicols, gray filter.

12. Same specimen, rotated $45^{\circ} ; \mathrm{R} 87 \mathrm{~N} 22 \mathrm{~A}$, crossed nicols, gray filter. 

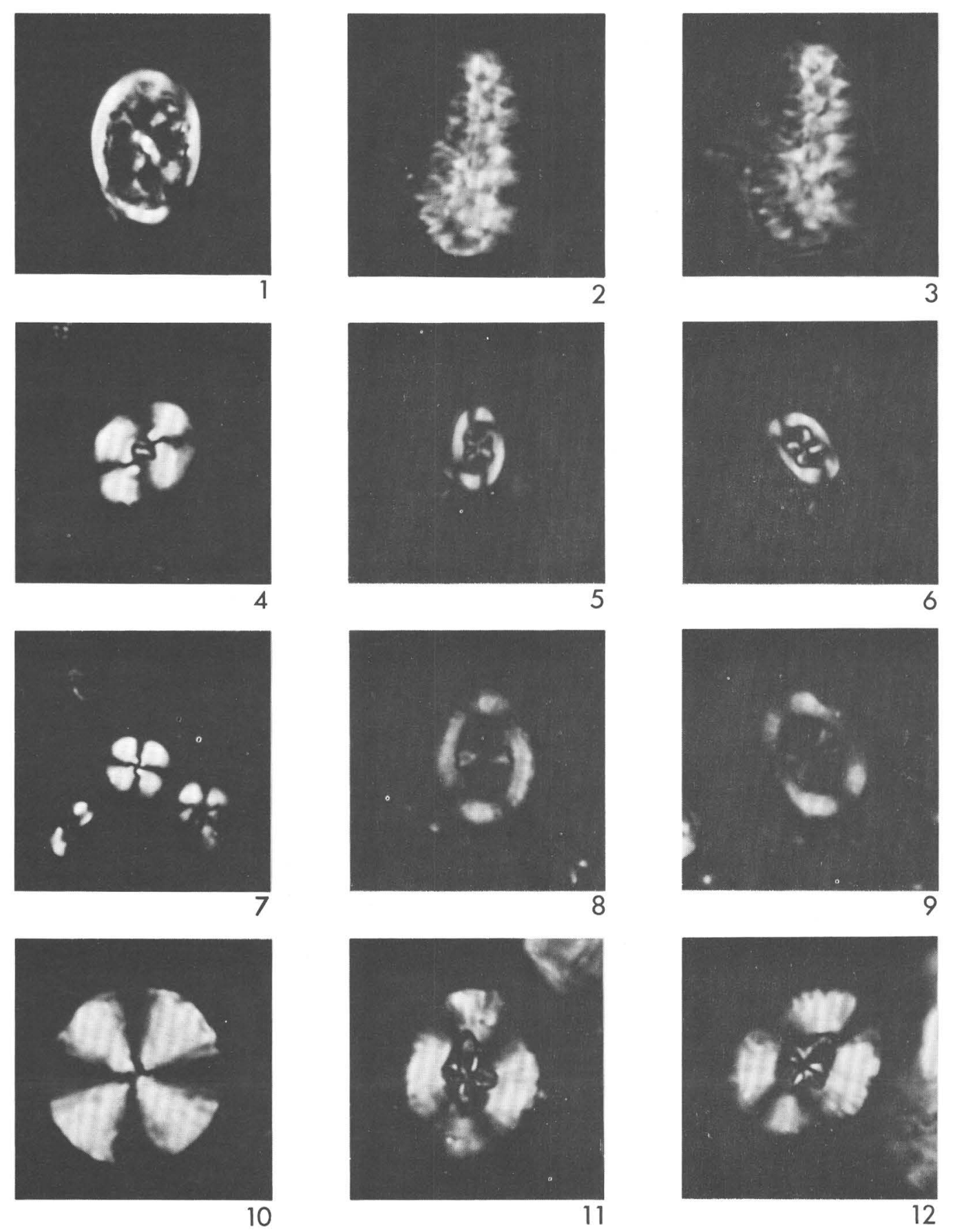
PLATE 2

Light micrographs $(x 2890)$ of selected nannofossils from the COST No. B-3 well. For species marked with an (*), please refer to "taxomomic notes" section.

Figures 1-2. *Brachiolithus? sp.

1. Septagonal form. Sample 13,130-13,140 ft; R87N5A; crossed nicols.

2. Hexagonal form. Sample 12,730-12,740 ft; R86N36A; crossed nicols.

3. Conusphaera mexicana Trejo, Sample 12,470-12,480 ft; R86N30A; crossed nicols, gray filter.

4. *Bidiscus? canthus Wilcoxon, Sample 12,630-12,640 ft; R86N33A; crossed nicols.

5. *Hexalithus aff. H. noelae Loeblich and Tappan, Sample 12,020-12,030 ft; R86N25A; crossed nicols.

6. Polycostella beckmannii Thierstein, Sample 13,840-13,850 ft; R87N16A; crossed nicols, blue filter. Present from 13,450 to $13,930 \mathrm{ft}(4,100-4,246 \mathrm{~m})$ in COST No. B-3 we11, but the lowest occurrences may be the result of caving (see text).

7-9. *Polycostella senaria Thierstein.

7. Specimen with seven ridges. Sample 12,920-12,930 ft; R87N3A; crossed nicols.

8. Specimen with six ridges. Sample 13,230-13,240 ft: R87N9A; crossed nicols.

9. Specimen with six ridges. Sample 13,320-13,330 ft; R87N15A; crossed nicols.

10. Micrantholithus obtusus Stradner, Sample 12,020-12,030 ft; R86N24A; crossed nicols.

11. *Braarudosphaera aff. B. africana Stradner, Sample 8,260-8270 ft; R86N2A; crossed ntcols.

12. *Braarudosphaera africana Stradner, Sample 8,900-8,910 ft; R86N5A; crossed nicols.

13. *Micrantholithus sp., Sample 12,590-12,600 ft; R87N32A; crossed nicols. 

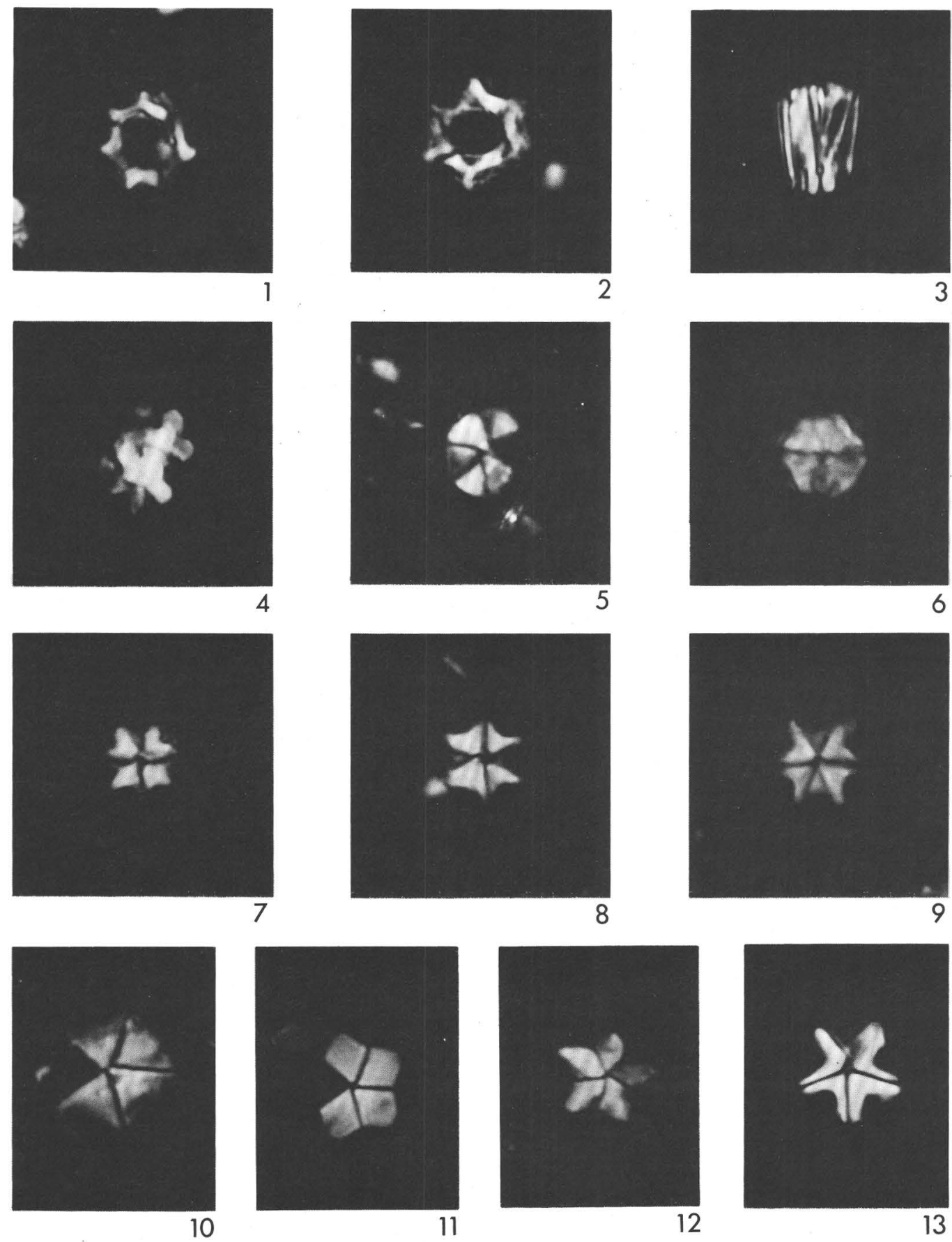



\section{ORGANIC GEOCHEMISTRY}

R. E. Miller, D. M. Schultz, G. E. Claypool, M. A. Smith, H. E. Lerch, D. Ligon, D. K. Owings, and C. Gary

\section{PURPOSE AND SCOPE}

The $\operatorname{cosT}$ No. B-3 well was drilled to a depth of $15,820 \mathrm{ft}(4,822 \mathrm{~m})$ for the purpose of estimating the petroleum potential and determining the stratigraphy and sedimentary history of the Baltimore Canyon Mid-Atlantic slope. In this petroleum geochemistry study, the major objectives were to (1) evaluate those sedimentary units that could be considered as potential and possible liquid-petroleum or natural-gas source rocks, and (2) estimate and define the possible effects of mud additives on the source-rock characteristics.

\section{DEFINITION OF TERMS AND CONCEPTS}

The general concepts of thermal maturation of organic matter and petroleum generation employed in this study largely follow those of Vassoyevich and others (1970) and Tissot and Welte (1978). Terms used to describe the source-rock rlchness, maturity, and potential follow the usage of the reports by Claypool and others (1977) and Miller and others (1979). The organic richness of a source bed and its petroleum potential may be measured by (1) a minimum amount of total organic carbon (0.7-1.0 weight percent for argillaceous rocks), (2) pyrolytic oil yields in excess of $0.2-0.3$ percent, and (3) solvent-extractable hydrocarbon concentrations in excess of $100-500 \mathrm{ppm}$. The degree to which organic matter progresses through a series of time-dependent kinetic reactions is expressed as the maturation stage of a source rock or source bed. Because some source beds contain organic matter that is predominantly of the humic and lignin type (hydrogen-poor), it is necessary for such rocks to contain more organic carbon than those sedimentary units that may contain predominantly marine algal organic matter (hydrogen-rich) to be considered as a petroleum source bed. The required higher organic-carbon contents in the hydrogen-poor organic matter are based on the poorer convertibility of lignin and humic substances. Therefore, the nature and type of organic matter may be as significant as the total amount of organic matter in evaluation of the effectiveness of a source bed.

Those sedimentary rocks that contain a predominance of blochemically derived hydrocarbons but which can be shown to be capable of generating petroleum hydrocarbons by pyrolysis are categorized as "immature." When organic-rich sedimentary rocks have not been altered by petroleum-generating reactions to the extent that a minimum amount of petroleum has been generated and physically expelled, the source rock is defined as "immature" (Claypool and others, 1977; Miller and others, 197).

The major criteria that characterize and distinguish the stages of thermochemical conversion of the organic matter to oil are the molecular composition and the relative concentration of the indigenous extractable hydrocarbons. Source beds are described as being "mature" when extractable hydrocarbons are present in quantities of about 1-2 percent of the total organic carbon and the hydrocarbons are compositiona1ly identical to petroleum. To define a source rock as "mature" infer. that a thermochemical conversion of the disseminated organic matter in shales or other sedirents has taken place (Claypool and others, 1977; M11ler and others, 1979).

The terms "potential" and "posstble" source rock refer to the degree of thermal maturity that an organic-rich rock has attained, ranging from "immature" (or "potential") source rock to "mature" (or "possible") source rock (Claypool and others, 1977; Miller and others, 1979).

\section{ANALYTICAL PROCEDURE}

In the present study, the USGS aralyzed a serles of 24 well-cuttings samples from depths 
of $3,810 \mathrm{ft}(1,161 \mathrm{~m})$ to $15,600 \mathrm{ft}(4,755 \mathrm{~m})$. Prior to opening the sealed cans, a measured volume of the dead-volume air was withdrawn, and the $\mathrm{C}_{1}$ to $\mathrm{C}_{4}$ hydrocarbon composition and distribution were determined on a Hewlett Packard model 5830 gas chromatograph equipped with a 6-ft $x$ 0.125-in. (1.8-m x $0.318-\mathrm{cm})$ Porapak $R$ column. The column temperature was programmed from an initial injection temperature of $149^{\circ} \mathrm{F}\left(65^{\circ} \mathrm{C}\right)$ at $11^{\circ} \mathrm{F} / \mathrm{min}\left(6^{\circ} \mathrm{C} / \mathrm{min}\right)$ for 11 minutes; it was then programmed at $22^{\circ} \mathrm{F} / \mathrm{min}$ $\left(12{ }^{\circ} \mathrm{C} / \mathrm{min}\right)$ to a final temperature of $356^{\circ} \mathrm{F}$ $\left(180^{\circ} \mathrm{C}\right)$. After the gas analyses for the $C_{1}$ to $\mathrm{C}_{4}$ light hydrocarbons were completed, the samples used in the experimental work were carefully removed from the 1-qt (0.95-L) sample cans and thoroughly washed through a Tyler number 100 mesh screen under running water to remove as much of the effects from the drilling mud as possible. While still wet, about 0.2 oz avdp $(5 \mathrm{~g})$ of each washed sample was immediately placed in a vial and stored under degassed water for analyses of the gasoline-range $\left(\begin{array}{lll}C_{4} & \text { to } & C_{7}\end{array}\right)$ hydrocarbons by gas chromatography. The gasoline-range $\left(C_{4}\right.$ to $\left.C_{7}\right)$ hydrocarbons were determined by adding a known volume (0.04-0.07 oz avdp; 1-2 g) of sediment to a known volume of water in a sealed microblender at $198^{\circ} \mathrm{F}$ $\left(92^{\circ} \mathrm{C}\right)$. After blending the sediment for 5 minutes, the liberated light and gasoline hydrocarbons $\left(C_{1}\right.$ to $\left.C_{7}\right)$ diffused into the trapped air space at the top of the blender. A sample of the liberated gas was then injected onto the Perkin Elmer 3920 gas chromatograph equipped with a 50-ft $(15-\mathrm{m})$ ScOT column with hexadecane-hexadecene-Kel-f (HHK) mixed phase. The column was operated 1sothermally at $77^{\circ} \mathrm{F}$ $\left(25^{\circ} \mathrm{C}\right)$.

The washed sample cuttings retained by the Tyler 100 mesh screen were afr and oven dried at $95^{\circ}-104^{\circ} \mathrm{F}\left(35^{\circ}-40^{\circ} \mathrm{C}\right)$. Each wet-sieved and dried sample was 11thologically described under a binocular microscope, and all forelgn substances were removed. Table 4 shows the 1ithologic descriptions of the samples analyzed. After each sediment sample was picked, it was passed through a set of Tyler mesh screens, and only those rock chips larger than 10-20 mesh were retalned for the $\mathrm{C}_{15}$ + hydrocarbon studies. Each sample was then ground, using a mortar and pestle, to pass through a 60-mesh screen and weighed. Allquots were taken from the ground sample for tota1-organic-carbon determinations and thermal pyrolysis analysis.

Detalls of the solvent-extraction techniques, liquid-column chromatography, and gas-chromatography procedures used for the $\mathrm{C}_{15}{ }^{+}$ liquid-hydrocarbon analyses have been described previously (Miller and others, 1979). The general steps employed Involve Soxhlet-solvent extraction, followed by removal of sulfur, and then elution-column chromatograph: on silica ge1. The saturated (paraffin-naphthene) fractions were analyzed both qualitatively and quantitatively on Perkin Elmer 3920 gas chromatographs. The columns used for the qualitative work were 8-ft $\times 0.125-i n$. (2.4-m x $0.318-\mathrm{cm}$ ) stainless steel, packed with 3 percent oV-101, 100-to- 120 mesh GCQ. The column temperature was $176^{\circ} \mathrm{F}\left(80^{\circ} \mathrm{C}\right)$ at injection and was temperature programmed at a rate of $29^{\circ} \mathrm{F} / \mathrm{min}$ $\left(16^{\circ} \mathrm{C} / \mathrm{min}\right)$ for 8 minutes; it was then programmed at $14^{\circ} \mathrm{F} / \mathrm{min}\left(8^{\circ} \mathrm{C} / \mathrm{min}\right)$ to a final temperature of $572^{\circ} \mathrm{F}\left(300^{\circ} \mathrm{C}\right)$. Quantitative evaluations were made on an OV-1 50-ft (15-m) SCOT column. The column was held isothermally at an injection temperature of $212^{\circ} \mathrm{F}\left(100^{\circ} \mathrm{C}\right)$ for 1 minute; it was then temperature programmed at $7^{\circ} \mathrm{F} / \mathrm{min}$ $\left(4^{\circ} \mathrm{C} / \mathrm{min}\right)$ to a final temperature of $473^{\circ} \mathrm{F}$ $\left(245^{\circ} \mathrm{C}\right)$ and held at the final temperature until $\mathrm{n}-\mathrm{C}_{32}$ eluted.

The following expression, modified from Hunt (1974), was used to calculate the Carbon Preference Index (CPI):

$\frac{\left(\% \mathrm{nC}_{25}+\% \mathrm{nC}_{27}+\% \mathrm{nC}_{29}+\% \mathrm{nC}_{31}\right)}{\left(\% \mathrm{nC}_{24}+\% \mathrm{nC}_{26}+\% \mathrm{nC}_{28}+\% \mathrm{nC}_{30}\right.}+\frac{\left(\% \mathrm{nc}_{25}+\% \mathrm{nC}_{27}+\% \mathrm{nC}_{29}+\% \mathrm{nC}_{31}\right)}{\% \mathrm{nc}_{26}+\% \mathrm{nC}_{28}+\% \mathrm{nc}_{30}+\% \mathrm{nC}_{32}}$

2

Total organic carbon is a messure of the organic richness of a source rocl.e Analyses were performed by the USGS (In triplicate) on dried, welghed allquots of the carbonate-free residue produced by leaching with tot, 6-Normal hydrochloric acid of approximately $0.07 \mathrm{oz}$ avdp $(0.2 \mathrm{~g})$ of ground sample (1ess than $60 \mathrm{mesh}$ ). The samples were combusted in a Perkin Elmer model 240 Carbon, Hydrogen, Nitrogen Analyzer. organic-carbon analyses for the thermalpyrolysis studies were also porformed by Rinehart Laboratories, Arvada, colo., on equivalent sample splits using a chromic-acid oxidation method outlined in Bush (1970).

The thermal-pyrolysis analyses reported here were performed by the USGS on a Rock-Eval system following the principles of source-rock characterization of Espitalie and others (1977). Terminology used to describe the thermal-pyrolysis measurements follows that of Claypool and Reed (1976), Claypool and others (1977), Tissot and Welte (1978), and Miller and others (1 979). The volatile-hydrocarbon content $\left(S_{1}\right)$ is the free or existing hydrocarbon component (expressed as $\mathrm{mgHC} / \mathrm{gC}(\mathrm{pFt})$ ) that $1 \mathrm{~s}$ already present in the rock and that is volatilized when the rock is heated at $481^{\circ} \mathrm{F}$ $\left(250^{\circ} \mathrm{C}\right)$ for $5 \mathrm{~min}$. Hydrocarbons and related compounds that are generated by pyrolysis at temperatures from about 480 to $1,020^{\circ} \mathrm{F}(250$ to $550^{\circ} \mathrm{C}$ ) from the nonvolatile organic matter are 
Table 4.--Lithologic descriptions of COST No. B-3 well cuttings used for organic geochemical analyses

\begin{tabular}{|c|c|c|}
\hline \multicolumn{2}{|c|}{ Depth } & \multirow{2}{*}{ Lithology } \\
\hline Feet & Meters & \\
\hline 3,810 & 1,161 & $\begin{array}{l}\text { Light-gray, soft, calcareous clay }(99 \\
\text { percent); broken shell fragments (micro and } \\
\text { macro); traces of glaucontte and quartz } \\
\text { sand grains ( } 1 \text { percent). }\end{array}$ \\
\hline 4,020 & 1,225 & $\begin{array}{l}\text { Light-gray, soft, calcareous clay }(100 \\
\text { percent); traces of broken shel1 fragments. }\end{array}$ \\
\hline 4,530 & 1,381 & $\begin{array}{l}\text { Light-gray, soft, calcareous clay }(100 \\
\text { percent); traces of broken shell fragments. }\end{array}$ \\
\hline 5,190 & 1,582 & $\begin{array}{l}\text { Light-to medium-11ght gray, calcareous shales } \\
\text { ( } 95 \text { percent); discrete broken angular } \\
\text { glauconitic sand with traces of } \\
\text { Foraminifera (5 percent). }\end{array}$ \\
\hline 5,610 & 1,710 & 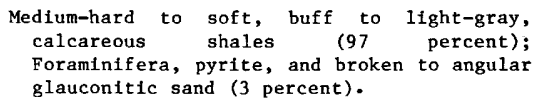 \\
\hline 6,100 & 1,859 & 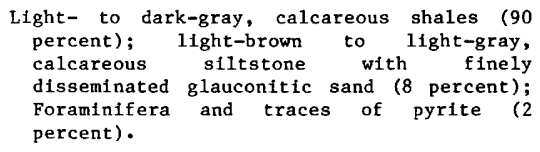 \\
\hline 6,700 & 2,042 & $\begin{array}{l}\text { Light-brown to light-gray, silty, micaceous } \\
\text { shale with medium to coarse, angular, } \\
\text { clear, quartz sand ( } 90 \text { percent); well- } \\
\text { rounded glauconitic sand, broken shell } \\
\text { fragments, and Foraminifera ( } 8 \text { percent); } \\
\text { pyrite and carbonaceous organic matter (2 } \\
\text { percent). }\end{array}$ \\
\hline 7,200 & 2,195 & $\begin{array}{l}\text { Light-brown to dark-gray, silty, micaceous } \\
\text { shale with traces of calcitic or dolomitic } \\
\text { cement ( } 90 \text { percent); rounded glauconitic } \\
\text { sand, pyrite, carbonaceous organic matter, } \\
\text { and broken shells ( } 10 \text { percent). }\end{array}$ \\
\hline 7,710 & 2,350 & $\begin{array}{l}\text { Light- to medium-gray, micaceous, silty } \\
\text { claystone with light-brown calcareous } \\
\text { cement (85 percent); brown, angular, } \\
\text { cryptocrystalline chert fragments ( } \\
\text { percent); fine-grained sand with calcareous } \\
\text { cement and glauconitic pellets ( } 5 \text { percent); } \\
\text { pyrite, carbonaceous organic matter, } \\
\text { Foraminifera, shell fragments (5 percent). }\end{array}$ \\
\hline 8,220 & 2,505 & $\begin{array}{l}\text { Light- to dark-gray, medium-soft, friable, } \\
\text { calcareous, micaceous claystone ( } 40 \\
\text { percent); coarse, angular, quartz sand }(40 \\
\text { percent); 11ght-brown to light-yellow, } \\
\text { slightly calcareous argillaceous siltstone } \\
\text { (15 percent); pyrite, carbonaceous organic } \\
\text { matter, and traces of Foraminifera (5 } \\
\text { percent). }\end{array}$ \\
\hline 8,700 & 2,652 & $\begin{array}{l}\text { Dark-gray to 1ight-gray, calcite-cemented } \\
\text { claystone to silty mudstone ( } 75 \text { percent); } \\
\text { fine-grained, silty quartz grains floating } \\
\text { in argillaceous matrix ( } 20 \text { percent); } \\
\text { pyrite, carbonaceous organic matter, } \\
\text { Foraminifera (5 percent). }\end{array}$ \\
\hline
\end{tabular}

$9,200 \quad 2,804 \quad$ Light- to medium-gray, calcareous, silty clay (50 percent); coarse- to fine-grained, subangular to rounded, frosted quartz sand with calcite cement ( 40 percent); grayishbrown to tan limestone ( 5 percent); pyrite, glauconitic sand, trace of micaceous sand (5 percent).

9,700 2,957 Light-gray to greenish-gray, calcareous, slightly micaceous, hard, brittle shale to mudstone ( 90 percent); light-buff to brown, dolomitic shale (7 percent); pyrite, Foraminifera, and well-rounded, frosted quartz grains ( 3 percent).
Table 4.--Lithologic descriptions of COST No. B-3 well cuttings used for organic geochemical analyses--Continued

\begin{tabular}{|c|c|c|}
\hline & th & \\
\hline Feet & Meters & \\
\hline
\end{tabular}

$10,300 \quad 3,139 \quad$ Coarse- to medium-grained, sut angular moderately well sorted, slightly, frosted, quartz sandstone ( 55 percent); dark- to light-gray, micaceous shale (40 percent); gray to light-tan limestone, pyrite, carbonaceous organic matter, and traces of glauconitic sandstone ( 5 percent).

$10,800 \quad 3,292$ Dark-gray, micaceous, silty shele (45 percent); 1ight-brown to tan limestone with traces of gray or buff to brown pellets of siderite ( 30 percent); coarse- to mediumgrained, subangular to subrounded, moderately sorted, frosted sandstone with calcite cement (24 percent); glauconitic sand, carbonaceous organic matter (1 percent).

$11,300 \quad 3,444$ Dark-gray to greenish-gray, brittle shale with waxy luster ( 50 percent); finegrained, moderately well sorted, buff to white sandstone with calcite cenent ( 35 percent); light-tan to gray, microcrystalline limestone (10 percent); buff to light-gray siltstone, carbonaceous organic matter (5 percent).

$11,800 \quad 3,597$ Dark-gray to grayish-brown, noncalcareous, waxy, micaceous, silty shale ( 25 percent); gray, fine-grained, micaceous sandstone with traces of calcite cement (65 percent); grayish-brown to tan, crypto-cr'stalline limestone ( 9 percent); glauconite, carbonaceous organic matter ( 1 percent).

$12,300 \quad 3,749 \quad$ Brownish-gray, micaceous, s11ty shale (70 percent); white to buff or gra\%, silty limestone (25 percent); grayish-white, limestone (25 percent); grayish-white,
calcite-cemented sandstone with traces of pyrite and greentsh-gray glaucontte grains (5 percent).

$12,800 \quad 3,901 \quad$ Light-brown to tan, silty, micaceous shale ( 50 percent); brown to buff, fine-grained, calcareous sandstone (40 percent); 11ghtgray to greenish-brown, micaceous, slightly calcareous sandy shale with traces of pyrite (10 percent)

13,300 4,054 Dark-gray to black, slightly silty, calcareous shale ( 80 percent); buff to light-gray, fine-grained, subangular to subrounded sandstone with calcite cement (19 percent); pyrite (1 percent).

$13,700 \quad 4,176$ Greenish-gray to dark-gra, slight 1y silty, micaceous shale ( 60 percent); Iight- to medium-gray, cryptocrystalline limestone with traces of pyrite ( 40 percent).

$14,300 \quad 4,359$

Light-gray to buff, fine-grained sandstone (25 percent); dark- to light-gray, slightly silty micaceous shale with traces of pyrite (75 percent).

$14,900 . \quad 4,542$

Dark-brown to grayish-black, slightly calcareous, micaceous shale (40 percent); light-gray to buff or white, mediumgrained, slightly calcareous sands tone with abundant blotite ( 30 percent); $\tan$ to grayish-white, cryptocrystalline limestone with traces of carbonaceous organic matter (30 percent).

15,600 4,755 Dark-gray to black, micaceous shale (70 percent); 1ight-tan to grayish-buff, medium-grained sandstone with sone traces of biotite (20 percent); 1ight-tan to brown, cryptocrystalline limestone with traces of carbonaceous matter (10 percent). 
defined by the term $S_{2}$ and are also expressed in units of $\mathrm{mgHC} / \mathrm{gC}$ (ppt). Carbon dioxide generated from the kerogen is designated $\mathrm{S}_{3}$ and is expressed in units of $\mathrm{mgCO}_{2} / \mathrm{gC}$ (ppt).

If it is assumed that the pyrolysis measurements are not influenced by external interference from nonindigenous hydrocarbons, then a semi-quantitative evaluation of the original generation potential of the source rock that has been effectively transformed into hydrocarbons may be made and is represented by the symbol $\mathrm{S}_{1}$. The residual generation potential, that has not been used to generate hydrocarbons, is represented by the symbol $\mathrm{s}_{2}$. The sum, $\left[\mathrm{S}_{1}+\mathrm{S}_{2}\right]$, can be expressed on $a$ weight-percent basis as a measure of the generation potential of the source rock when expressed in $\mathrm{KgHC} / \mathrm{ton}$ rock (Tissot and Welte, 1978). In this study the sum $\left(S_{1}+S_{2}\right)$ is expressed on a weight-percent basis.

The ratio of pyrolytic-hydrocarbon yield to organic carbon in percent $\left[\mathrm{S}_{1}+\mathrm{S}_{2}\right.$ /organic $\mathrm{C}$ percent] is defined as a measure of the type and convertibility of the organic matter to hydrocarbons. In this study, the ratio $\left[\mathrm{s}_{1} / \mathrm{s}_{1}+\right.$ $S_{2}$ ] is employed as a measure of the thermal maturation of the organic matter. The maximum temperature at which the yield of volatile organic compounds is produced by pyrolysis of the solid organic matter $\left(\mathrm{T}_{\mathrm{S}_{2}}\right)$ is also an indicator of thermal maturation (Tissot and Welte, 1978). In this study, the ratio of $\left[\mathrm{S}_{2}\right.$ /organic $\mathrm{C}$ ] is designated as the hydrogenindex; [ $\mathrm{S}_{3}$ /organic $\mathrm{C}$ ] is defined as the oxygenindex and may provide an indirect measure of the type of kerogen (Tissot and Welte, 1978). Atomic (hydrogen/carbon) ratios, carbon-isotopic compositions ( $\left.\mathrm{C}^{13} \mathrm{PDB}\right)$, and classes of relative percent of kerogen are also used to evaluate the type of kerogen.

\section{RESULTS AND DISCUSSION}

This study has focused on determining the source-rock potential of the sedimentary units present in the CoST No. B-3 well. A combination of geochemical methods has been employed and evaluations have been made where inconsistencies appear to occur. The geochemical data and interpretations generated in this report are those of the USGS unless otherwise credited.

The chemical composition and abundance of the extractable organic matter in source rocks generally reflects the richness and type of the original organic matter as well as the degree of thermal maturation, provided that the extractable organic matter is indigenous to the sediments (Tissot and We1te, 1978). The USGS extractable-organic-matter data, saturated paraffin-naphthene gas chromatograms, and lighthydrocarbon analyses for the COST N?. B-3 we11 are shown in table 5 and figures 31 through 36. Characterization of the original genetic and residual source-rock potential, as well as the type and thermal maturity of the organic matter, was carried out by the USG? using the thermal pyrolysis method. These pyrolysis results are summarized in table 6 .

In addition to the independent geochemical studies conducted by the USGS, organic geochemical analyses completed by outside contractors were reported for the $\cos T$ B-3 participants on a separate suite of $B-3$ well samplès. The results of this work have been summarized by Smith (1979), and the data have been made avallable by the USGS Conservation Division, Atlantic Area office for Resource Evaluation, Washington, D.C., for reference and selective comparison. The contract data incorporated in this present study include a summary depth profile of the types of organic matter, as determined by optical mathods, for relative kerogen types and abundance (percent), and atomic hydrogen-carbon ratios (Core Laboratorles, Inc., 1979); and stable-carbon1sotope analyses of the saturated paraffinnaphthene and aromatic hydrocarbons, as well as total extractables and kerogen (J. G. Erdman, Phillips Petroleum Company, written communication, 1979). These source-rock typeparameters are compared with the US 75 therma1pyrolysis kerogen-convertibility, as well as hydrogen and oxygen indices, and are shown in figure 37. Source-rock-maturity characteristics, based on optical thermal alteration index (TAI) values and vitrinite reflectance $\left(R_{0}\right)$ values (Core Laboratorles, Inc., 1979) have been incorporated in this study and are compared with the USGS thermal-pyrolysis temperatures of maximum yield $\left(\mathrm{T}_{\mathrm{S}_{2}}\right)$ and the Carbon Preference Index (CPI) in figure 38.

Because drilling operations must use certain mud additives, it is essential that each additive be "fingerprinted" by gas chromatography for the molecular composition and distribution of the $\mathrm{C}_{15}+$ saturated paraffinnaphthene hydrocarbons, in order to avold misleading interpretations of type and maturity of indigenous material. The gas chromatograms of the saturated paraffin-naphthene hydrocarbons and the concentrations of the paraffinnaphthene, aromatic, and nitrogen-sulfur-oxygen (NSO) compounds of the avallable additives are shown in figure 39 and table 7, respentively. 
Data on Source-rock Richness, Type, and Maturity of Organic Matter

\section{Tertiary}

The Tertiary section in the COST No. B-3 we11 $(3,800-6,040 \mathrm{ft}$; $1,158-1,841 \mathrm{~m})$, is composed of calcareous mudstone, claystone with smaller amounts of argillaceous limestone, and siltstone. Trace components consist primarily of muscovite, shell fragments, microcrystalline limestone, buff-colored chert, glauconite grains, and, above $5,160 \mathrm{ft}(1,573 \mathrm{~m})$, some coal fragments (Lachance, 1979) (table 4).

The COST No. B-3 Tertiary section has an average total-organic-carbon value of 1.5 percent (by weight), which is considerably above the worldwide average of 0.27 percent for carbonate sediments according to Hunt (1961) and Gehman (1962). This higher total-organic-carbon value probably reflects the effect of oxygenminimum zone deposition of organic-rich clays and silts in these outer neritic to middle-shelf calcareous sediments. The total extractable hydrocarbons, however, average only $58 \mathrm{ppm}$, which falls within the very poor range for liquid-hydrocarbon source rocks (Philipp1, 1957; Baker, 1972). For these Tertiary sediments, the ratio of total hydrocarbon to total organic carbon (percent) averages 0.40 , suggesting thermally immature sediments that hare not generated and expelled liquid or gaseous hydrocarbons. This interpretation is consistent with the CPI value of 2.7 for the resolved saturated paraffin-naphthene hydrocarbons and the comparatively high concentration of NSO compounds ( $320 \mathrm{ppm}$ ) and lends further supnort to the view that the Tertiary saturated paraffinnaphthene hydrocarbons are predominantly indigenous, biogenic, and thermally immature (table 5, fig. 31).

The ratio of the saturated paraffinnaphthene to aromatic hydrocarbons is 2.9 , an unusually high value for thermally immature sediments. This particular ratio, howerer, is not considered to respond to thermal history alone, but may also reflect the type and percent of the organic matter as well as the possible presence of mud-additive contamination. As a

Table 5.--Organic carbon and extractable organic matter, COST No. B-3 well

\begin{tabular}{|c|c|c|c|c|c|c|c|}
\hline \multicolumn{2}{|c|}{ Depth } & \multirow{2}{*}{$\begin{array}{l}\text { Organic } \\
\text { carbon } \\
\text { (percent) }\end{array}$} & \multirow{2}{*}{$\begin{array}{l}\text { Total } \\
\text { hydrocarbon } \\
\text { (ppm) }\end{array}$} & \multirow{2}{*}{$\begin{array}{l}\text { Ratio of } \\
\text { hydrocarbon to } \\
\text { organ1c carbon }\end{array}$} & $\begin{array}{l}\text { Ratio of } \\
\text { extractable }\end{array}$ & \multirow[t]{2}{*}{$\begin{array}{l}\text { Ratio of } \\
\text { saturated } \\
\text { hydrocarbon } \\
\text { to aromatic } \\
\text { hydrocarbon }\end{array}$} & \multirow{2}{*}{$\begin{array}{l}\text { Carbon } \\
\text { Preference } \\
\text { Index } \\
\text { (CPI) }\end{array}$} \\
\hline Feet & Meters & & & & organic matter & & \\
\hline \multicolumn{8}{|c|}{ Tertiary } \\
\hline 3,810 & 1,161 & 1.19 & 95.0 & 0.80 & 0.34 & 1.42 & 2.17 \\
\hline 4,020 & 1,225 & 1.73 & 77.0 & .44 & .19 & 1.28 & 3.47 \\
\hline 4,530 & 1,381 & 3.08 & 64.0 & .21 & .16 & 1.13 & 3.22 \\
\hline 5,190 & 1,582 & 1.18 & 49.0 & .42 & .28 & 1.49 & $2.6 c$ \\
\hline 5,610 & 1,719 & .45 & 6.0 & .13 & .13 & 9.33 & 1.71 \\
\hline \multicolumn{8}{|c|}{ Upper Cretaceous } \\
\hline 6,100 & 1,859 & 0.41 & 12.0 & 0.30 & 0.20 & 3.44 & $1.5 C$ \\
\hline 6,700 & 2,042 & .92 & 50.0 & .54 & .42 & 1.39 & 1.65 \\
\hline 7,200 & 2,195 & 1.57 & 36.0 & .23 & .22 & .96 & 1.27 \\
\hline 7,710 & 2,350 & .72 & 780.0 & 10.83 & .63 & 1.83 & 1.02 \\
\hline 8,220 & 2,505 & .42 & 48.0 & 1.15 & .37 & .61 & 1.92 \\
\hline \multicolumn{8}{|c|}{ Lower Cretaceous } \\
\hline 8,700 & 2,652 & 0.87 & 73.0 & 0.84 & 0.50 & 1.63 & 0.89 \\
\hline 9,200 & 2,804 & .66 & 143.0 & 2.17 & .65 & $1 \cdot 30$ & 1.21 \\
\hline 9,700 & 2,957 & .72 & 52.0 & .72 & .42 & .78 & 2.24 \\
\hline 10,300 & 3,139 & .50 & 81.0 & 1.62 & .49 & .34 & 1.03 \\
\hline 10,800 & 3,292 & .70 & 106.0 & 1.52 & .56 & .94 & 1.50 \\
\hline 11,300 & 3,444 & .55 & 69.0 & 1.25 & .48 & .37 & 1.67 \\
\hline 11,800 & 3,597 & 1.05 & 387.0 & 3.69 & .65 & .92 & $1.7 i$ \\
\hline 12,300 & 3,749 & .64 & 45.0 & .70 & .40 & .20 & 2.47 \\
\hline \multicolumn{8}{|c|}{ Upper Jurassic } \\
\hline 12,800 & 3,901 & 0.76 & 229.0 & 3.00 & 0.72 & 1.44 & 0.69 \\
\hline 13,300 & 4,054 & .89 & $1,064.0$ & 11.95 & .81 & 2.48 & .70 \\
\hline 13,700 & 4,176 & .41 & 67.0 & 1.63 & .54 & .99 & 1.46 \\
\hline 14,300 & 4,359 & 1.05 & 716.0 & 6.82 & .82 & $2 \cdot 32$ & .95 \\
\hline 14,900 & 4,542 & 1.02 & $288 \cdot 0$ & 2.83 & .69 & 1.09 & 1.12 \\
\hline 15,600 & 4,755 & 2.25 & 160.0 & .71 & .57 & .55 & $1 \cdot 31$ \\
\hline
\end{tabular}




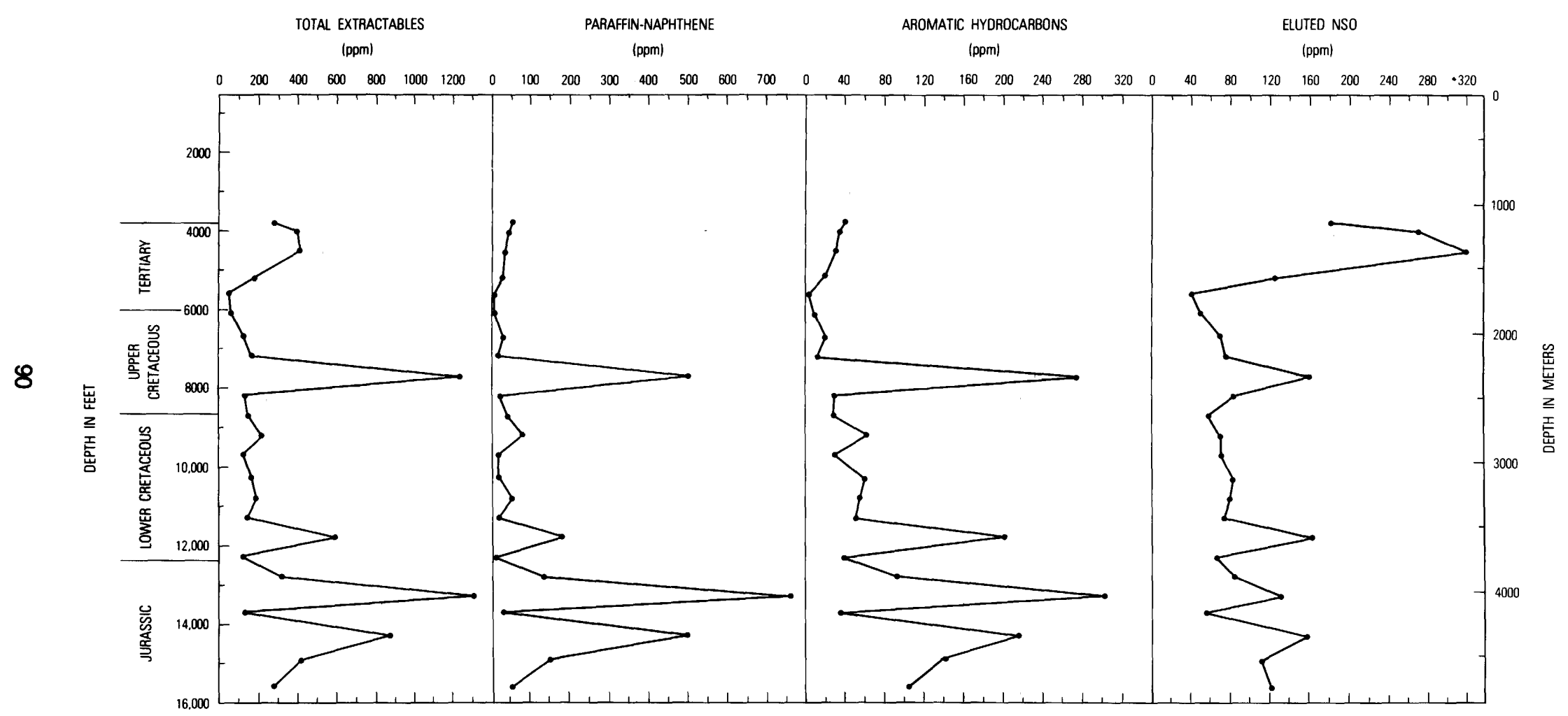

Figure 31.--Summary of organic-richness analyses on $\mathrm{C}_{15}$ hydrocarbon extractables of samples from the COST No. B-3 we11. 


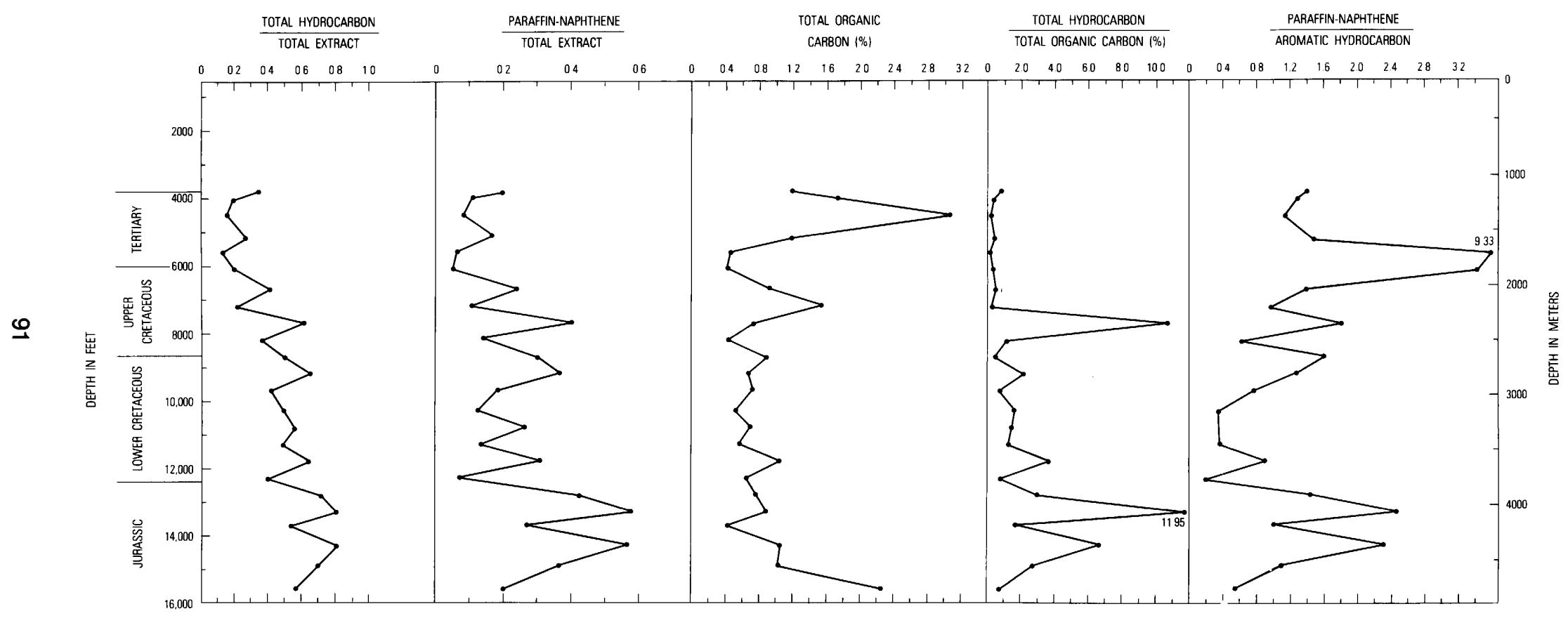

Figure 31.--Summary of organic-richness analyses on $\mathrm{C}_{15^{+}}$hydrocarbon extractables of samples from the COST No. B-3 well--continued. 
result, this seemingly inconsistent value reflects more of the nature and type of the extractable hydrocarbons than the thermal history of these Tertiary sediments. A comparatively low ratio $(0.22)$ of total hydrocarbon extractables to total extractable organic matter for the Tertiary interval is belleved to be consistent with an interpretation of a predominantly indigenous, thermally uncontaminated, immature section (table 5, fig. 31).

Figure 32 shows a series of saturated paraffin-naphthene hydrocarbon gas chromatograms for Tertiary sediments down to $6,040 \mathrm{ft}(1,841$ $\mathrm{m})$. These gas chromatograms illustrate a predominantly bimodal distribution for the resolved aliphatics and a molecular hydrocarbon assemblage that ranges from $n-C_{14}$ to $n-C_{34}$. The paraffin-naphthene unresolved complex mixture is equal to or predominates over the resolved aliphatics, a characteristic signature that usually suggests a low-temperature thermal history for the liquid $\mathrm{C}_{15}+$ hydrocarbons. Inconsistent with this interpretation is the fact that the isoprenoid pristane and phytane hydrocarbons are dominated by the normal alkanes
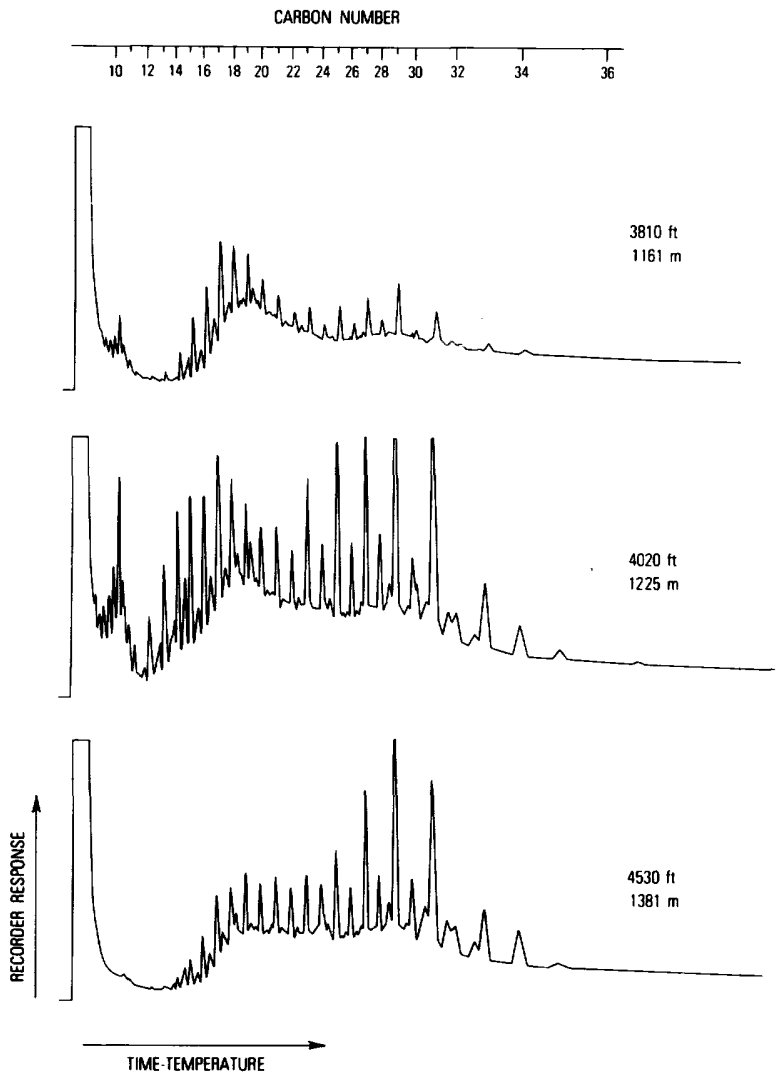

Figure 32.--Gas-chromatographic analyses of saturated paraffin-napthene hydrocarbons of Tertiary rocks above $6,040 \mathrm{ft}(1,841 \mathrm{~m}), \operatorname{cosT}$ No. B-3 we 11 . in these Tertiary rocks, a characteristic

The Tertiary light hydrocarbons $\left(\mathrm{C}_{1}\right.$ to $\left.\mathrm{C}_{4}\right)$ show the second highest concentration $(15,500$ ppm (volume $\mathrm{C}_{1}$ to $\mathrm{C}_{4}$ per volume of rock) at $4,020$ ft $(1,225 \mathrm{~m}))$ for the $\operatorname{CosT}$ No. B-3 well sample. In this same interval, the gasolinerange hydrocarbons $\left(\mathrm{C}_{5}\right.$ to $\left.\mathrm{C}_{7}\right)$ have a concentration of $700 \mathrm{ppm}$. The 10 gas-wetness percentage $\mathrm{C}_{2-} \mathrm{C}_{4} \times 100$ suggests that the major

$$
\overline{\mathrm{C}_{1}-\mathrm{C}_{4}}
$$

component of this shallow gas is probably blogenic methane (fig. 33). However, the n$\mathrm{C}_{4} / \mathrm{n}-\mathrm{C}_{7}$ ratio is much less than unity for the same interval. This particular ratio has been Interpreted as being diagnostic of diesel fuel and may suggest the influence of nonindigenous hydrocarbons posstbly associated with dieselfuel contamination (K. F. Thompron, written communication, 1977). The remainder of the Tertiary below 4,020 ft $(1,225 \mathrm{n})$ shows low concentrations (less than $200 \mathrm{ppm}$ ) of $\mathrm{C}_{1}$ to $\mathrm{C}_{4}$ and a progressive decrease in the amount of the $C_{5}$ to $C_{7}$ gasoline-range fraction to less than 50 ppm. Similarly, the gas-wetness percentage
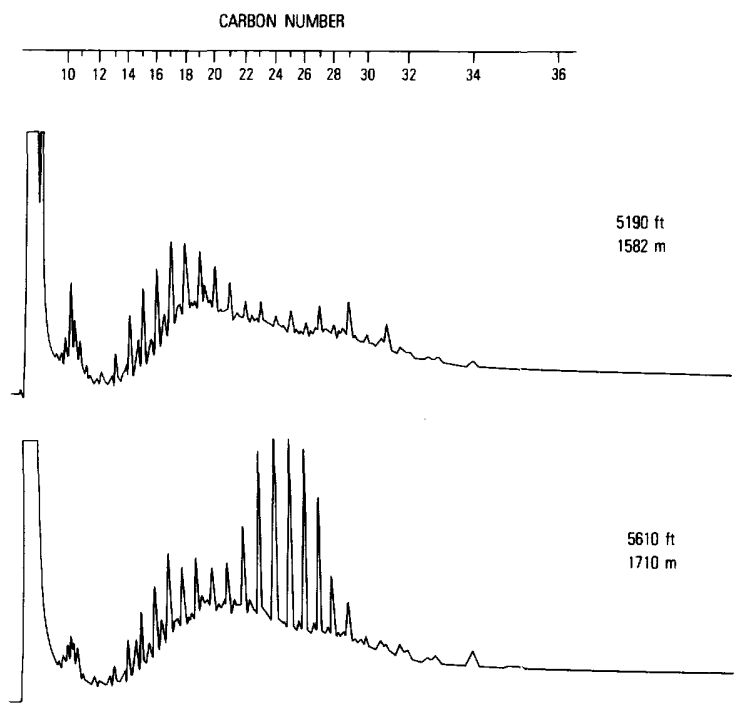
normally associated with mature hydrocarbons. 


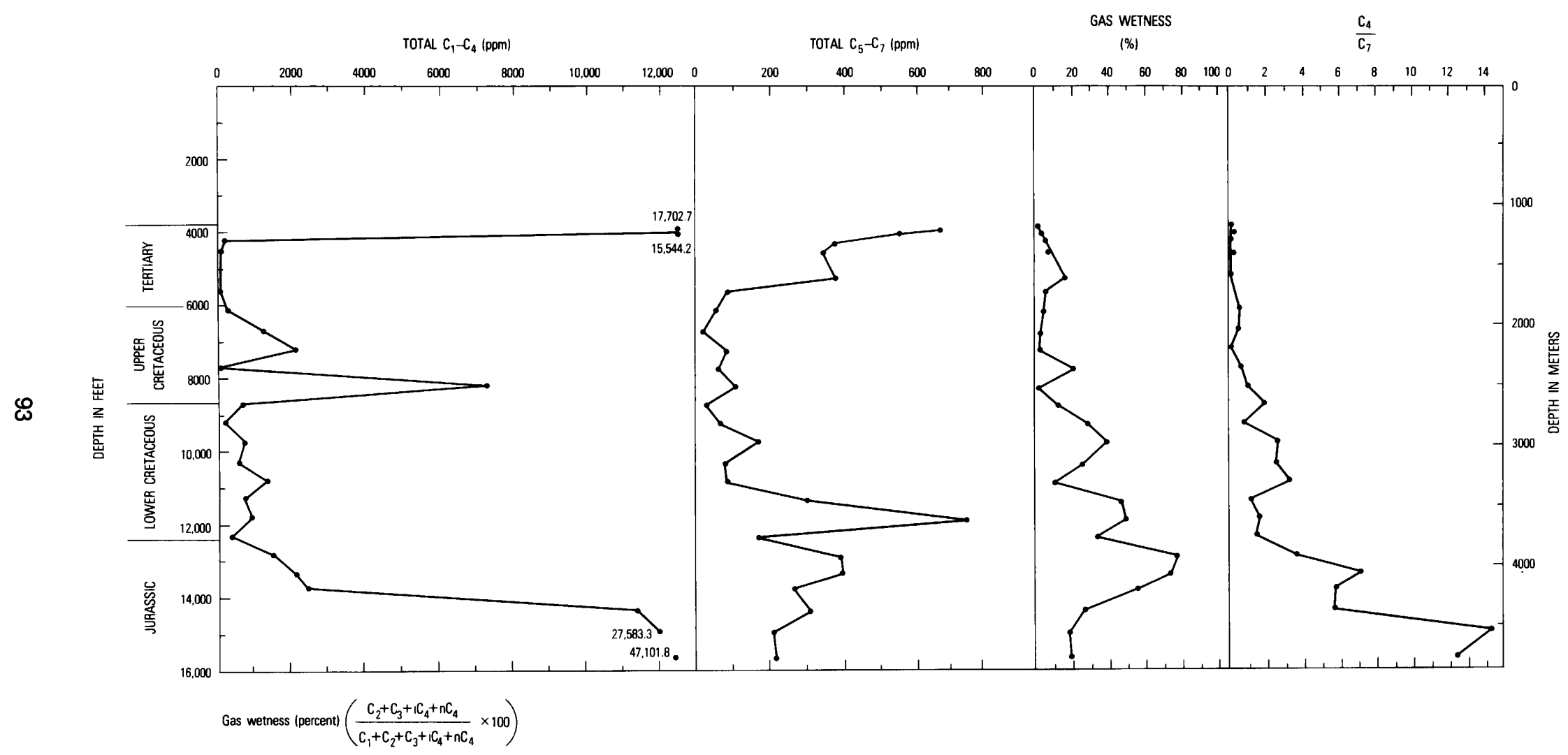

Figure 33.--Summary of light-hydrocarbon analyses from the Cost No. B-3 well. 
decreases with increased burial depth to values less than 5 percent (fig. 33). Such relationships tend to confirm low thermal maturity for the organic matter.

Thermal-pyrolysis maximum-yield temperatures for these Tertiary sediments range from 757 to $817^{\circ} \mathrm{F}\left(403^{\circ}\right.$ to $\left.436^{\circ} \mathrm{C}\right)$ which is consistent with an interpretation of thermal immaturity. The ratio of the total pyrolytic hydrocarbons $\left(S_{1}+s_{2}\right)$ to total organic carbon is a measure of the convertibility of the organic matter to hydrocarbons (Claypool and others, 1978; Miller and others, 1979). With the exception of one sample at 4,530 ft $(1,381 \mathrm{~m})$, which has a convertibility factor of 29.88 percent and also has the highest organic-carbon content (3.28 weight percent) in these Tertiary sediments, the average convertibility factor is 7.33 percent, which indicates the predominance of hydrogenlean kerogens. This low convertibility ratio is also reflected in the characterization of the kerogens by their hydrogen and oxygen indices of $129 \frac{\mathrm{mgHC}}{\mathrm{gC}}$ and $65 \frac{\mathrm{mgCO}_{2}}{\mathrm{gC}}$ respectively. The thermal-pyrolytic parameters indicate that the Tertiary sediments are thermally immature and have poor liquid-hydrocarbon source-rock potential (table 6 ).

\section{Upper Cretaceous}

Upper Cretaceous sediments extend from 6,040 to $8,690 \mathrm{ft}(1,841$ to $2,649 \mathrm{~m})$ and are characterized by outer neritic, gray siltstones grading into mudstones in the section from 6,040 to $6,290 \mathrm{ft}(1,841$ to $1,917 \mathrm{~m})$. Below this interval, from 6,290 to $8,200 \mathrm{ft}(1,917$ to 2,499 $\mathrm{m})$, the sediments are composed of outer neritic to marginal-marine calcareous shales that are intercalated with light-gray to buff, dolomitic, sandy limestones. Glauconite is common to abundant in the more sandy intervals. From 8,200 to 8,690 ft $(2,499$ to $2,649 \mathrm{~m})$, interbedded sandstones, shales, ant mudstones occur with relatively minor limestones and coal (table 4; Lachance, 1979).

The Upper Cretaceous interval has an average total-organic-carbon content of 0.83 percent, an average total-oxtractablehydrocarbon content of $36 \mathrm{ppm}$, and an average NSO concentration of $67 \mathrm{ppm}$ if the 7,710-ft $(2,350-\mathrm{m})$ sample is excluded from the calculations. This anomalous sample has higher concentrations of total hydrocarbons (779 ppm) and of NSO's (160 ppm), but the total organic carbon ( 0.72 weight percent) is comparable with the average total organic carbon fcr the Upper

Table 6.-Wrganic-carbon and thermal-Analusis (Rocl-Fval purolusis) ${ }^{1}$ data for samples from the coST No. R-3 well

[--- undetectable or unable to determine; * numerically zero or one]

\begin{tabular}{|c|c|c|c|c|c|c|c|c|c|c|c|}
\hline $\begin{array}{l}\text { Samp } \\
\text { dep }\end{array}$ & & \multirow{2}{*}{$\begin{array}{l}\text { Total } \\
\text { organiç } \\
\text { carbon } \\
\text { (weight } \\
\text { percent) }\end{array}$} & \multirow{2}{*}{$\begin{array}{c}\mathrm{s}_{1} \\
\mathrm{mgHc} / \mathrm{g} \\
(\mathrm{ppt}) \\
\end{array}$} & \multirow{2}{*}{$\begin{array}{c}\mathrm{S}_{2} \\
\mathrm{mgHC} / \mathrm{g} \\
(\mathrm{ppt})\end{array}$} & \multirow{2}{*}{$\begin{array}{l}\mathrm{S}_{3} \\
\underset{(p p t)}{\mathrm{mgCO}_{2} / g}\end{array}$} & \multirow{2}{*}{$\begin{array}{l}\mathrm{S}_{1}+\mathrm{S}_{2} \\
\text { (weight } \\
\text { percent) }\end{array}$} & \multirow{2}{*}{$\begin{array}{l}\mathrm{S}_{2} / \text { org. } \mathrm{C} \\
\mathrm{mgHC} / \mathrm{gC}\end{array}$} & \multirow{2}{*}{$\begin{array}{l}\mathrm{S}_{3} / \text { org } \cdot \mathrm{C} \\
\mathrm{mgCO}_{2} / \mathrm{gC}\end{array}$} & \multirow{2}{*}{$\begin{array}{l}\mathrm{TS} \\
{ }^{\circ} \mathrm{C} \\
\end{array}$} & \multirow[t]{2}{*}{$\mathrm{s}_{1} / \mathrm{s}_{1}+\mathrm{s}_{2}$} & \multirow[t]{2}{*}{$\begin{array}{c}\mathrm{S}_{1}+\mathrm{S}_{2} \\
\text { org. }\end{array}$} \\
\hline Feet & Meters & & & & & & & & & & \\
\hline \multicolumn{12}{|c|}{ Tertiary } \\
\hline 3,810 & 1,161 & 1.03 & 0.122 & 0.27 & 1.58 & 0.04 & 26 & 153 & 421 & 0.31 & 3.79 \\
\hline 4,020 & 1,225 & 1.76 & .023 & 2.39 & .98 & .24 & 136 & 56 & 406 & .01 & 13.69 \\
\hline 4,530 & 1,381 & 3.28 & -- & 9.80 & 1.14 & .98 & 299 & 35 & 403 & * & 29.88 \\
\hline 5,190 & 1,582 & 1.19 & --- & 1.38 & .44 & .14 & 116 & 37 & 427 & * & 11.76 \\
\hline 5,610 & 1,710 & .54 & -- & .37 & .26 & .04 & 69 & 48 & 436 & * & 7.41 \\
\hline \multicolumn{12}{|c|}{ Upper Cretaceous } \\
\hline 6,100 & 1,859 & 0.33 & 0.027 & * & 0.54 & 0.003 & --- & 164 & $-\infty$ & * & 0.91 \\
\hline $6,7 \cap 0$ & 2,042 & 1.30 & .011 & 4.08 & .48 & .41 & 314 & 37 & --- & .003 & 31.54 \\
\hline 7,200 & 2,195 & 1.59 & -- & .31 & .58 & .03 & 20 & 36 & -- & $\star$ & 1.89 \\
\hline 7,710 & 2,350 & 1.05 & --- & 1.75 & .95 & .11 & 100 & 90 & 430 & * & 10.48 \\
\hline 8,220 & 2,505 & .40 & --- & .32 & .67 & .03 & 81 & 168 & 436 & $\star$ & 7.50 \\
\hline \multicolumn{12}{|c|}{ Lower Cretaceous } \\
\hline 8,700 & 2,652 & 1.31 & -- & 0.45 & 0.73 & 0.05 & 35 & 56 & 421 & * & 3.82 \\
\hline 9,200 & 2,804 & .87 & --- & * & * & * & $-\infty$ & $-\infty$ & -- & * & -- \\
\hline 9,700 & 2,957 & .45 & -- & .24 & 1.24 & .02 & 52 & 275 & 424 & * & 4.44 \\
\hline 10,300 & 3,139 & .69 & -- & * & .51 & * & -- & 74 & -- & * & -- \\
\hline 10,800 & 3,292 & .74 & --- & .19 & .53 & .02 & 26 & 72 & 448 & * & 2.70 \\
\hline 11,300 & 3,444 & .70 & 0.034 & 1.29 & .55 & .13 & 185 & 79 & 436 & .03 & 18.57 \\
\hline 12,300 & 3,749 & .72 & -- & .25 & .51 & .02 & 34 & 71 & 436 & * & 2.78 \\
\hline \multicolumn{12}{|c|}{ Upper Jurassic } \\
\hline 12,800 & 3,901 & 0.92 & 0.034 & 0.38 & 1.18 & 0.04 & 41 & 128 & 445 & 0.08 & 4.35 \\
\hline 13,300 & 4,054 & .70 & .13 & .50 & 2.06 & .06 & 71 & 295 & 430 & $.2 n$ & 8.57 \\
\hline 13,700 & 4,176 & .37 & .07 & * & .52 & .01 & --- & 141 & -- & * & 2.70 \\
\hline 14,300 & 4,359 & 1.15 & .05 & .42 & .46 & .05 & 37 & 40 & 448 & .11 & 4.35 \\
\hline 14,900 & 4,542 & 1.25 & .04 & 1.07 & .50 & .11 & 86 & 40 & 436 & .04 & 8.80 \\
\hline 15,600 & 4,755 & 2.12 & .03 & 1.50 & .37 & .16 & 75 & 17 & 439 & .02 & 7.55 \\
\hline
\end{tabular}

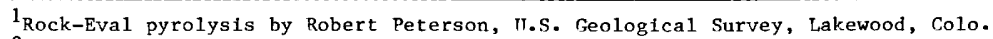

${ }^{2}$ organic-carbon analyses, wet-oxidation method by Rinehart Laboratories, Inc., Arvada, Colo. 
Cretaceous. With the exception of the 7,710-ft (2,350-m) sample, the Upper Cretaceous sediments are poor to lean source rocks for the generation of liquid hydrocarbons (table 5, fig. 31 ).

The saturated paraffin-naphthene hydrocarbon gas chromatograms for the Upper Cretaceous rocks are shown in figure 34. The gas chromatograms for the $6,100-f t(1,859-\mathrm{m})$ to $7,200-f t(2,195-m)$ samples are characterized by the dominant bimodal, unresolved, paraffinnaphthene mixture. The less pronounced resolved aliphatics in this interval have a molecular composition and boiling-point range that extend from about $n-C_{15}$ to $n-C_{30}$, with a CPI ratio that averages 1.47. In samples from $7,200 \mathrm{ft}(2,195$ m) to $8,690 \mathrm{ft}(2,649 \mathrm{~m})$, the bimodal unresolved paraffin-naphthene hydrocarbons are comparable with the resolved allphatics, and the CPI ratio averages 1.41 (table 6).

The longer chain $\left(n-C_{20}\right.$ to $\left.n-C_{30}\right)$ hydrocarbons are predominant in the 7,710-ft $(2,350-m)$ sample and have an odd-to-even ratio of 1.04. The shorter chain $\left(n-C_{17}\right.$ to $\left.n-C_{20}\right)$ hydrocarbons are the major, resolved, aliphatic, molecular spectes in the $8,220-\mathrm{ft}(2,505-\mathrm{m})$ sample (fig. 34). The longer chain hydrscarbon assemblages may be indicative of plant-wax hydrocarbons, or, for those sections ir which the input of terrestrial sediment and organic matter is negligible, the longer chain hydrocarbons may be derived from marine planktonic algae and bacterla. When marine plankton and algae are the major source of input, the CPI value may be near unity even in thermally immature sediments (Tissot and Welte, 1978). Thus, the low CPI value fornd in sediments otherwise indicated to be immature indicates derivation of long-chain n-alkanes from marine plants. The shorter chain normal aliphatics $\left(\mathrm{n}-\mathrm{C}_{15}\right.$ to $\left.\mathrm{n}-\mathrm{C}_{17}\right)$ also occur in marine zooplankton, with pristane as the major saturated component along with unsaturated isoprenoid hydrocarbons and the unsaturated hydrocarbon squalene (B1umer, 1967; B1uner and others; 1969; Gelpi and Oro, 1968).

Throughout the Upper Cretaceous siction, only the $8,220-f t \quad(2,505-\mathrm{m})$ sample contains significant concentrations of $C_{1}$ to $C_{4}$ light hydrocarbons $(7,000 \mathrm{ppm})$ and $C_{5}$ to $C_{7}$ gasolinerange hydrocarbons (125 ppm). The gas is mainly
CARBON NUMBER

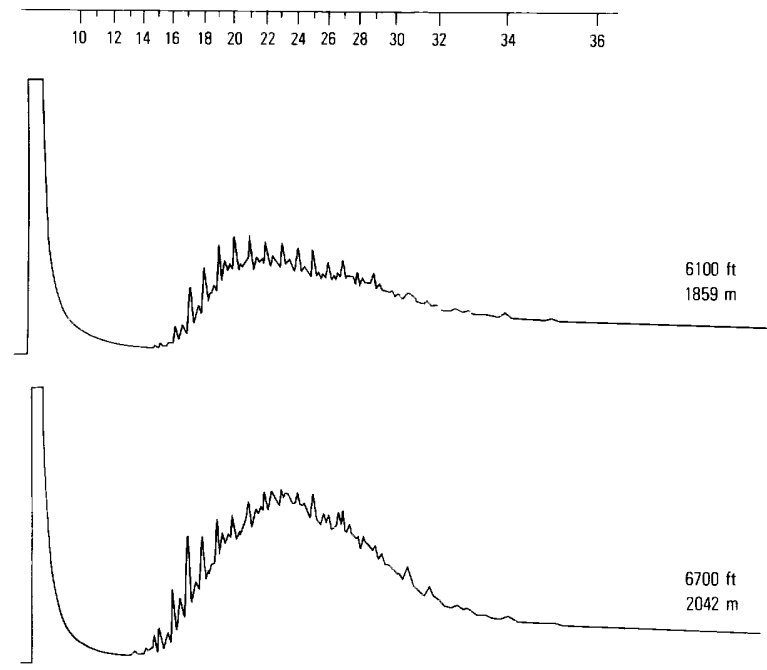

CARBON NUMBER

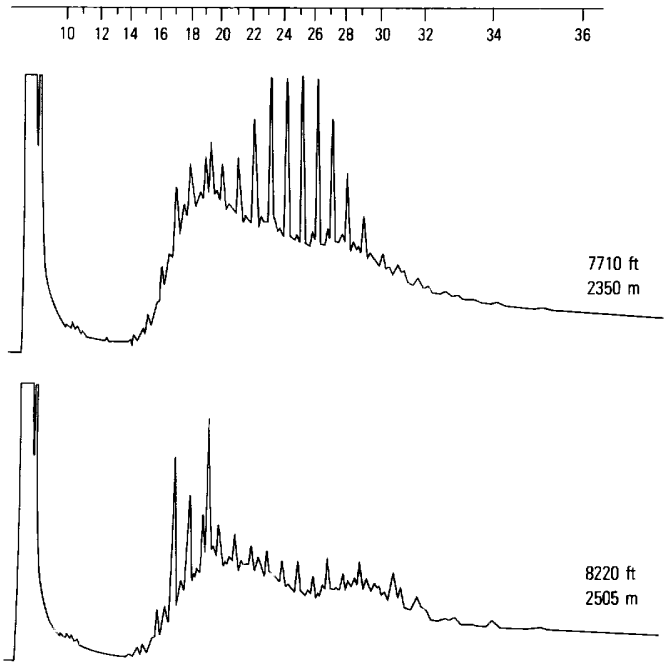

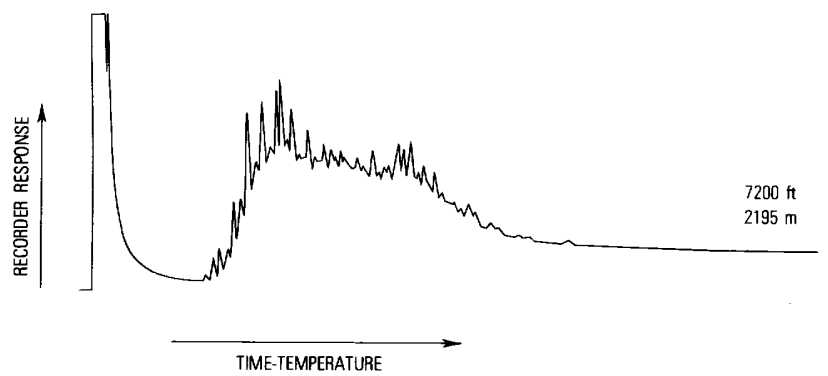

Figure 34.--Gas-chromatographic analyses of saturated paraffin-napthene hydrocarbons of Upper Cretaceous rocks below $6,040 \mathrm{ft}(1,841 \mathrm{~m}), \operatorname{CosT}$ No. B-3 we 11 . 
composed of methane, with a gas-wetness value of less than 2 percent, which may indicate a low temperature history for the organic matter. A point that must not be discounted in the interpretation, however, is the value of the n$\mathrm{C}_{4} / \mathrm{n}-\mathrm{C}_{7}$ ratio, of approximately unity, which suggests the presence of trace amounts of nonindigenous hydrocarbons possibly from anthropogenic sources (fig. 33).

The thermal pyrolysis temperatures $\left(\mathrm{T}_{\mathrm{S}_{2}}\right)$ for Upper Cretaceous samples ranges from 790 to $817^{\circ} \mathrm{F}\left(421\right.$ to $\left.436^{\circ} \mathrm{C}\right)$ and fall within the range for thermally 1mmature organic matter (Tissot and Welte, 1978). Further support for an interpretation of thermally immature organic matter in the Upper Cretaceous section is provided by the average-total-hydrocarbon to total-extractable-matter ratio of 0.30 and an average CPI ratio of 1.4 (tables 5 and $6, \mathrm{fig}$. 31). The presence of hydrogen-defictent, gasprone kerogens in the major part of the Upper Cretaceous section is also indicated by the low average pyrolytic-hydrocarbon to organic-carbon ratio of 5.2 percent. This average-ratio calculation excludes the 6,700-ft (2,042-m) sample, which has a pyrolytic hydrocarbon/total organic carbon percent yleld of 31.54 . The higher ratio for the $6,700-\mathrm{ft}(2,042-\mathrm{m})$ sample indicates a greater proportion of hydrogen-rich, amorphous, alga1-type kerogens.

The very low to undetectable or unmeasurable generation potential $\left(S_{1}\right)$ as determined by pyrolysis is consistent with an interpretation of poor to lean 1iquidhydrocarbon source rocks for the major portion of the Upper Cretaceous section from 6,040 ft to $8,690 \mathrm{ft}(1,841$ to $2,649 \mathrm{~m})$ with the exception of the $6,700-\mathrm{ft}(2,042-\mathrm{m})$ sample. Further

evidence of the poor potential for 1iquidhydrocarbon generation for these Upper Cretaceous sediments is provided by an average pyrolytic-hydrogen index of $69 \frac{\mathrm{mgHC}}{\mathrm{gC}}$, and an average oxygen index of $103 \frac{\mathrm{mgCO}_{2}}{\mathrm{gC}^{2}}$ (tables 5 and 6, fig. 31).

\section{Lower Cretaceous}

The Lower Cretaceous section in the COST No. B-3 well ranges from $8,690 \mathrm{ft}(2,649 \mathrm{~m})$ to $12,400 \mathrm{ft}(3,780 \mathrm{~m})$ and is characterized by marginal-marine, shallow-shelf, and outer shelf depositional environments. The lithologies are sandy, calcareous shales and mudstones Intercalated with thin, 1ight-gray to brown sandstones and 1imestones interbedded with minor amounts of coal. Very small amounts of glauconite, pyrite, siderite, and shell fragments occur as trace constituents (table 4; Lachance, 1979).
The Lower Cretaceous interval is characterized by an average total-crganic-carbon content of 0.71 percent, an average totalextractable-hydrocarbon concentration of 120 $\mathrm{ppm}$, and an average NSO content of $84 \mathrm{ppm}$ (table 5, fig. 31). These organic-carbon and tota1extractable-hydrocarbon values indicate poor source-rock richness and quality for liquidhydrocarbon generation (table 5, fig. 31). The averages for the tota1-hydrocarbor to organiccarbon ratio (percent), the total-hydrocarbon to extractable-organic-matter ratio, and the saturated-paraffin-naphthene to aromatic ratio for the Lower Cretaceous are 1.56, 0.52, and 0.81 , respectively. These values suggest immature to marginally mature organic matter with respect to liquid-hydrocarbon generation (table 5, fig. 31).

The saturated paraffin-naphthene hydrocarbon gas chromatograms for the samples taken from the Albian section at depths of $8,700 \mathrm{ft}(2,652 \mathrm{~m})$ and $9,200 \mathrm{ft}(2,804 \mathrm{~m})$ are characterized by a bimodal, unresolved, complex mixture relative to the comparatively weak, resolvid aliphatic signatures (fig. 35). This is consistent with thermal immaturity. The resolved rormal alkanes have a molecular composition and range that extend from $n-C_{15}$ to $n-C_{30}$. Because of the restricted range and the effect that small concentration values may have on the CPI-ratio calculations of the concentrations beyond $n-C_{22}$, the use of the CPI ratio as an indicator of maturity is limited (M11ler and others, 1979; Swetland and others, 1978). In the Albian section, the CPI value for the $8,700-f t(2,652-$ m) sample is 0.88 , whereas the CPI ratio for the 9,200-ft $(2,804-m)$ sample is 1.21 . These ratios Imply that thermal-maturation processes may have started. However, the change in the ratio with depth of burial probably also reflects the variations in types of organic matter. The normal alkanes dominate the isoprenoid hydrocarbons (pristane and phytane) in the Albian samples and may reflect the nature of the organic matter as well as thernal-maturation effects. The saturated parafin-naphthene hydrocarbons for the Aptian ( $9,700 \mathrm{ft} ; 2,957 \mathrm{~m}$ ) and Barremian $(10,300 \mathrm{ft} ; 3,319 \mathrm{~m})$ samples, with differing CPI ratios of 2.24 and 1.03, respectively, nevertheless have similar gross compositions in that the bimodal, unresolved, complex mixture is equal to or dominates the resolved aliphatics. Such gas-cl romatographic features are unlike mature petroleum hydrocarbons and are consistent with thermal immaturity (fig. 35).

Lower Cretaceous (Hauterivian) rocks from 10,800 ft $(3,292 \mathrm{~m})$ to $12,300 \mathrm{ft}(3,749 \mathrm{~m})$ have 
CARBON NUMBER

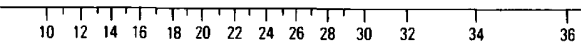
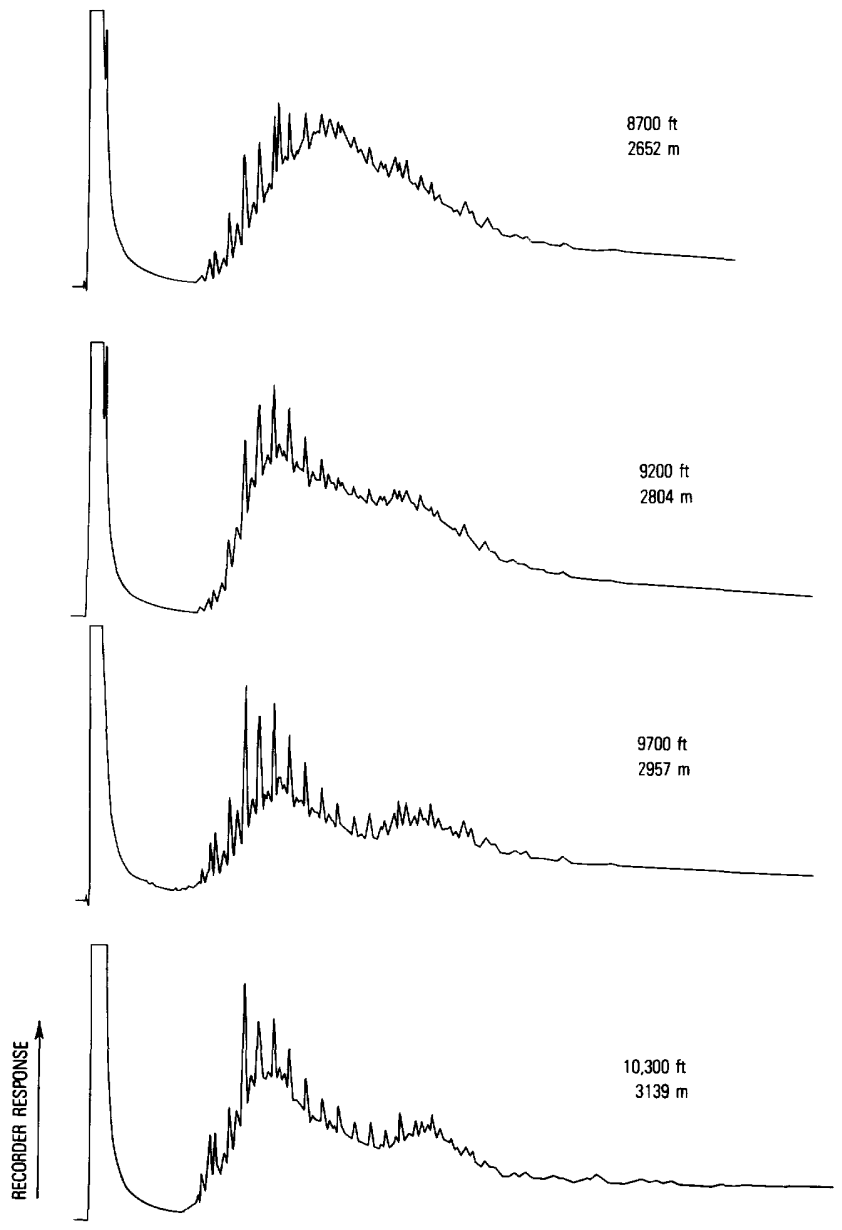

CARBON NUMBER
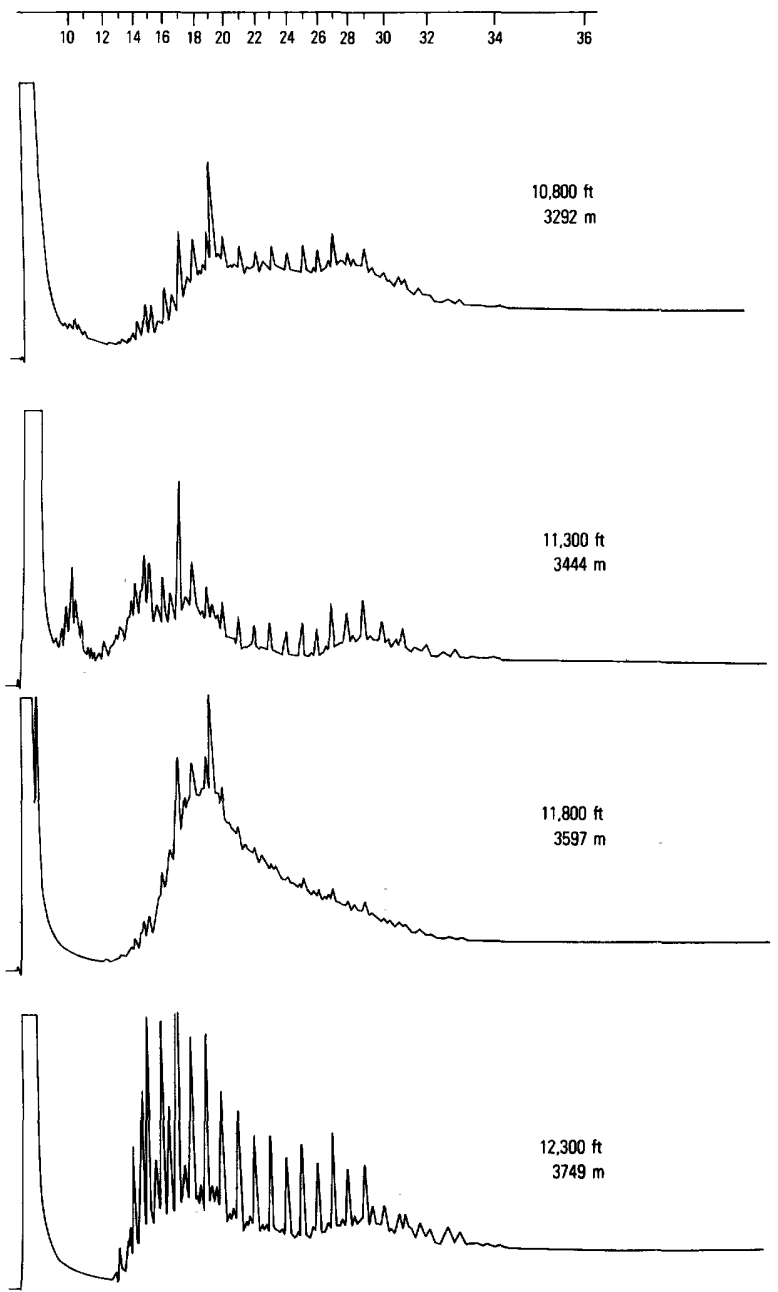

TIME-TEMPERATURE

F1gure 35.--Gas-chromatographic analyses of saturated paraffin-naphthene hydrocarbons of Lower Cretaceous rocks below $8,690 \mathrm{ft}(2,649 \mathrm{~m})$, COST No. B-3 well.

a saturated-hydrocarbon mixture which has a bimodal character. At $12,300 \mathrm{ft}(3,749 \mathrm{~m})$, however, the resolved aliphatics are equal to or dominate the blmodal, unresolved, complex mixture of cycloparaffins and naphthenes. Also at this depth, the resolved alfphatics have a CPI value of 2.466 , a hydrocarbon to organiccarbon ratio of 0.7 , a hydrocarbon to extractable-organic-matter ratio of 0.40 , and a saturated-hydrocarbon to aromatic ratio of 0.20. Each of these values is consistent with an inter-pretation of thermally immature organic matter (figs. 31 and 35, table 5).

Over the entire Lower Cretaceous interval, the $\mathrm{C}_{1}$ to $\mathrm{C}_{4}$ 11ght hydrocarbons are low, averaging only $685 \mathrm{ppm}$. The 12,300-ft (3,749-m) sample contains as much as 700 ppm of the gasoline-range $\left(C_{5}\right.$ to $\left.C_{7}\right)$ hydrocarbons, with a 50 percent gas-wetness rat10. This interval contains the highest gas-wetness percentase for the Lower Cretaceous interval. If the $n-C_{4} / n-C_{7}$ ratio is a true Indicator of the influence of diesel fuel, then the 1.5 ratio would suggest that anthropogentc influences from diesel fuel are probably not a significant factor in the 11,800 ft $(3,597 \mathrm{~m})$ sample. However, the low total-gas concentrations for this intervil may suggest that catagenic processes have not yet progressed to a significant degree (fig. : 3 ).

Thermal-pyrolysis analyses of the Lower Cretaceous rocks indicate that the most prevalent type of kerogens present are of the hydrogen-poor, oxygen-rich varlety, with an average hydrogen index of $74 \frac{\mathrm{mgHC}}{\mathrm{gC}}$ and ar 
average oxygen index of $114 \frac{\mathrm{mgCO}_{2}}{\mathrm{gC}}$. These values are consistent with the average pyrolytic convertibility of the organic matter, which is 6.57 percent. With the exception of the 10,800ft $(3,293-\mathrm{m})$ sample, which has an unusually high temperature of maximum yield $\left(\mathrm{T}_{\mathrm{S}_{2}}\right)$ of $838^{\circ} \mathrm{F}$ $\left(448^{\circ} \mathrm{C}\right)$, the temperature index ranges from 790 to $817^{\circ} \mathrm{F}\left(421^{\circ} \mathrm{C}\right.$ to $\left.436^{\circ} \mathrm{C}\right)$ and is consistent with an interpretation of marginal thermal immaturity for the Lower Cretaceous (table 6).

\section{Jurassic}

The Upper Jurassic interval penetrated in the $\operatorname{cosT}$ No. B-3 well ranges from $12,400 \mathrm{ft}$ $(3,780 \mathrm{~m})$ down to the total well depth of 15,820 ft $(4,822 \mathrm{~m})$ and includes outer to inner shelf and nonmarine sediments. The section from $12,400 \mathrm{ft}$ to $12,710 \mathrm{ft}(3,780 \mathrm{~m}$ to $3,874 \mathrm{~m})$ includes intercalated calcareous, 1ight-gray sandstones, medium- to dark-gray shales, and comparatively thin, gray to light-gray, oolitic 11mestones. Below $12,710 \mathrm{ft}(3,874 \mathrm{~m})$, the section is composed of increasing amounts of silty, micaceous, dark- to 1ight-gray, calcareous shales, and coals interbedded with oolitic, algal, and pelletal limestones (table 4; Lachance, 1979).

If the $13,300-f t(4,054-m)$ sample, which is belleved to contain nonindigenous extractable hydrocarbons, is excluded, then the Upper Jurassic sediments sampled here (table 5) have an average total-organic-carbon value of 1.09 percent, an average total-extractablehydrocarbon content of $285 \mathrm{ppm}$, and an average NSO concentration of $105 \mathrm{ppm}$. The organicrichness properties of the organic carbon and extractable hydrocarbons suggest that these sediments have fair to good source-rock potential (table 5, fig. 31 ).

The 13,300-ft $(4,054-\mathrm{m})$ sample has a totalorganic-carbon content of 0.89 percent and an extractable-hydrocarbon concentration of 1,063 ppm. The abnorma1ly high total-extractablehydrocarbon to total-organic-carbon ratio of 11.95 percent for this interval indicates the probable influence of nonindigenous hydrocarbons for this interval.

The CPI values and saturated paraffinnaphthene to aromatic average ratios for the Upper Jurassic interval are 1.33 and 1.28 , respectively. These ratios, together with the average hydrocarbon to organic-carbon ratio of 3.13 percent, indicate that the hydrocarbongeneration process is in progress (table 5, fig. 31).

The saturated paraffin-naphthene hydrocarbon gas chromatograms for the sample taken from the Tithonian section at a depth of 12,800 ft $(3,901 \mathrm{~m})$ are characterized by a strongly bimodal, unresolved, complex mixture that dominates a relatively narrow range from $n-C_{15}$ to $n-c_{26}$ of resolved aliphatics (fig. 36). Kimmeridgian samples from $13,300 \mathrm{ft}(4,054 \mathrm{~m})$, $13,700 \mathrm{ft}(4,176 \mathrm{~m}), 14,300 \mathrm{ft}(4,359 \mathrm{~m}), 14,900$ ft $(4,542 \mathrm{~m})$ and $15,600 \mathrm{ft}(4,755 \mathrm{~m})$ were examined. At $13,300 \mathrm{ft}(4,054 \mathrm{~m})$, the resolved aliphatics are very weak, poorly resolved, restricted in range $\left(n-c_{15}\right.$ to $\left.n-c_{22}\right)$, and dominated by a very strongly bimodal, unresolved, complex mixture of paraffinnaphthenes. The $13,700-\mathrm{ft}(4,176-\mathrm{m})$ sample has a comparatively well developed, resolved aliphatic component from $n-C_{15}$ to $n-C_{30}$ relative to a very weak, bimodal, unresolved mixture. From $14,300 \mathrm{ft}(4,359 \mathrm{~m})$ down to $\varepsilon$ burial depth of $15,600 \mathrm{ft}(4,755 \mathrm{~m})$, there is a progressive decrease in the magnitude of the unresolved envelope and a relatively consistert increase in the distribution and molecular composition of the resolved, aliphatic, saturated paraffinnaphthene hydrocarbons.

The Upper Jurassic shows a significant increase in the concentratior of $11 \mathrm{ght}$ hydrocarbons beginning with the 14,300-ft (4,359-m) sample, which has $a C_{1}$ to $C_{4}$ concentration of $11,300 \mathrm{ppm}$ and a gas wetness of 25 percent (fig. 33). The $C_{1}$ to $C_{4}$ light hydrocarbons show a further increase to 27,583 ppm at $14,900 \mathrm{ft}(4,542 \mathrm{~m})$ and $47,102 \mathrm{ppm}$ at $15,600 \mathrm{ft}(4,755 \mathrm{~m})$, with a gas wetness of $18-19$ percent. The $\mathrm{C}_{5}$ to $\mathrm{C}_{7}$ Easoline-range hydrocarbons average $285 \mathrm{ppm}$ for the Jurassic interval, and the $n-C_{4} / n-C_{7}$ ratio is well above unity, ranging from 1.5 to 14.0 . This indicates that anthropogenic sources are most probably not a factor. The progressive increase. In the $C_{1}$ to $\mathrm{C}_{4}$ light-hydrocarbon concentrations confirms the onset of thermal maturity $\varepsilon$ nd suggests significant generation of light hylrocarbons in sediments at depths below $14,300 \mathrm{ft}(4,359 \mathrm{~m})$. This interpretation is supported by the observed increase in concentration of the $C_{15}$ to $C_{20}$ hydrocarbons in the $\mathrm{C}_{15}+$ liquid-hytrocarbon gas chromatograms for samples below $14,300 \mathrm{ft}(4,359$ m) (figs. 33 and 36 ).

These Upper Jurassic sediments contain kerogens that are primarily hydrogen-poor and, based upon their organic-richness characteristics, may be classifled as good gasprone source rocks. This interpretation is consistent with the results of the thermalpyrolysis analyses which show the average hydrogen and oxygen indices to be $62 \frac{\mathrm{mgHC}}{\mathrm{gC}}$ and $110 \frac{\mathrm{mgCO}_{2}}{\mathrm{gC}}$, respectively, which are consistent with a hydrogen-poor, Type III (humic-coaly) 


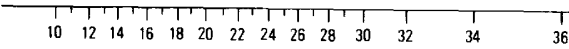
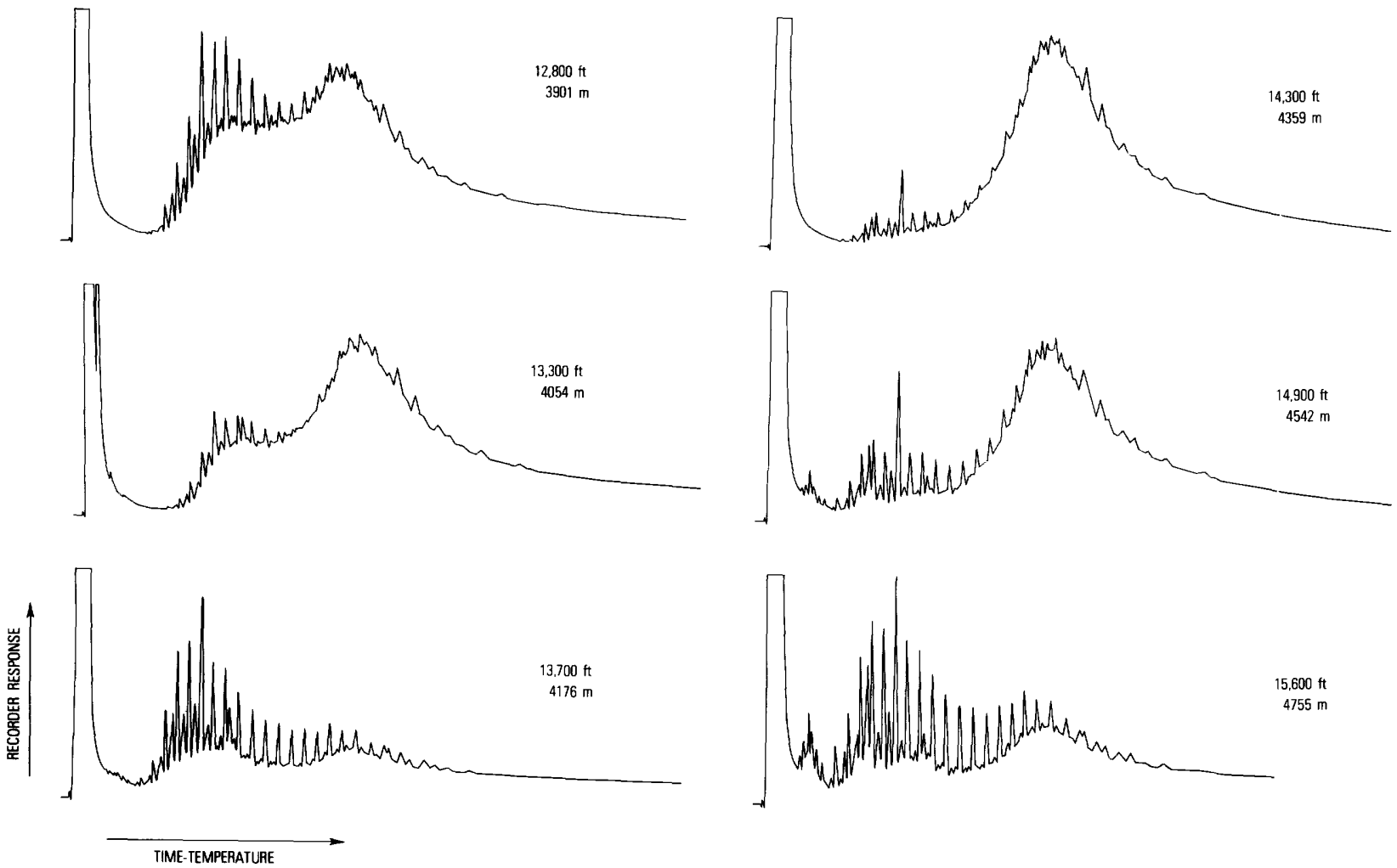

Figure 36.--Gas-chromatographic analyses of saturated paraffin-naphthene hydrocarbons of Jurassic rocks below $12,400 \mathrm{ft}(3,780 \mathrm{~m})$, COST No. B-3 we11.

kerogen. The temperature of maximum pyrolysis yleld $\left(\mathrm{T}_{\mathrm{S}_{p}}\right)$ for the solid organic matter in the Upper Jurassic ranges from 806 to $838^{\circ} \mathrm{F}$ $\left(430^{\circ}\right.$ to $\left.448^{\circ} \mathrm{C}\right)$ (table 6$)$.

\section{A Comparative Discussion of Kerogen Types, Stable-Carbon-Isotope Ratios, Atomic-Hydrogen to Carbon Ratios, Thermal Alteration Indices, and Vitrinite Reflectance with USGS Thermal-Pyrolysis and CPI Values}

The measurements of the types of organic matter in the Tertiary, Cretaceous, and Upper Jurassic sediments of the COST No. B-3 well are shown in figure 37. Geochemical parameters Indicative of the nature of the solid organic matter are the relative kerogen type and abundance (Core Labs, Inc.), atomic-hydrogen to carbon ratio (Core Labs, Inc.), carbon isotoplc composition (Phillips Petroleum Company), and the hydrogen and oxygen indices as determined by thermal pyrolysis (USGS). Figure 38 summarizes properties sensitive to thermal maturity. Such parameters include the thermal alteration index (TAI) and vitrinite reflectance $\left(R_{0}\right)$ (Core Labs, Inc.), and the Carbon Preference Index (CPI) and temperature of maximum pyrolysis yield $\left(\mathrm{T}_{\mathrm{S}_{2}}\right)$ (USGS).

\section{Tertiary}

The most abundant kerogens in the Tertiary section are the algal-amorphous type, which have atomic-hydrogen to carbon ratios that vary from 1.0 to 1.25 . However, the values of the kerogen-pyrolysts hydrogen and oxygen irdices in the same interval are low, averaging $129 \frac{\mathrm{mgHC}}{\mathrm{gC}}$ and $65 \frac{\mathrm{mgCO}_{2}}{\mathrm{C}}$, respectively. The stable-carbonisotope ratios, ${ }^{\mathrm{g} C} \mathrm{C} /{ }^{12} \mathrm{C}$ (given as $\mathrm{C}^{13}$ values in parts per thousand (permil) standard deviations from the PeeDee Belemnite (PDB) carbonate standard), have values of 23.5 to 26.0 , which is in the range for organic carbon derived from marine as well as ronmarine 


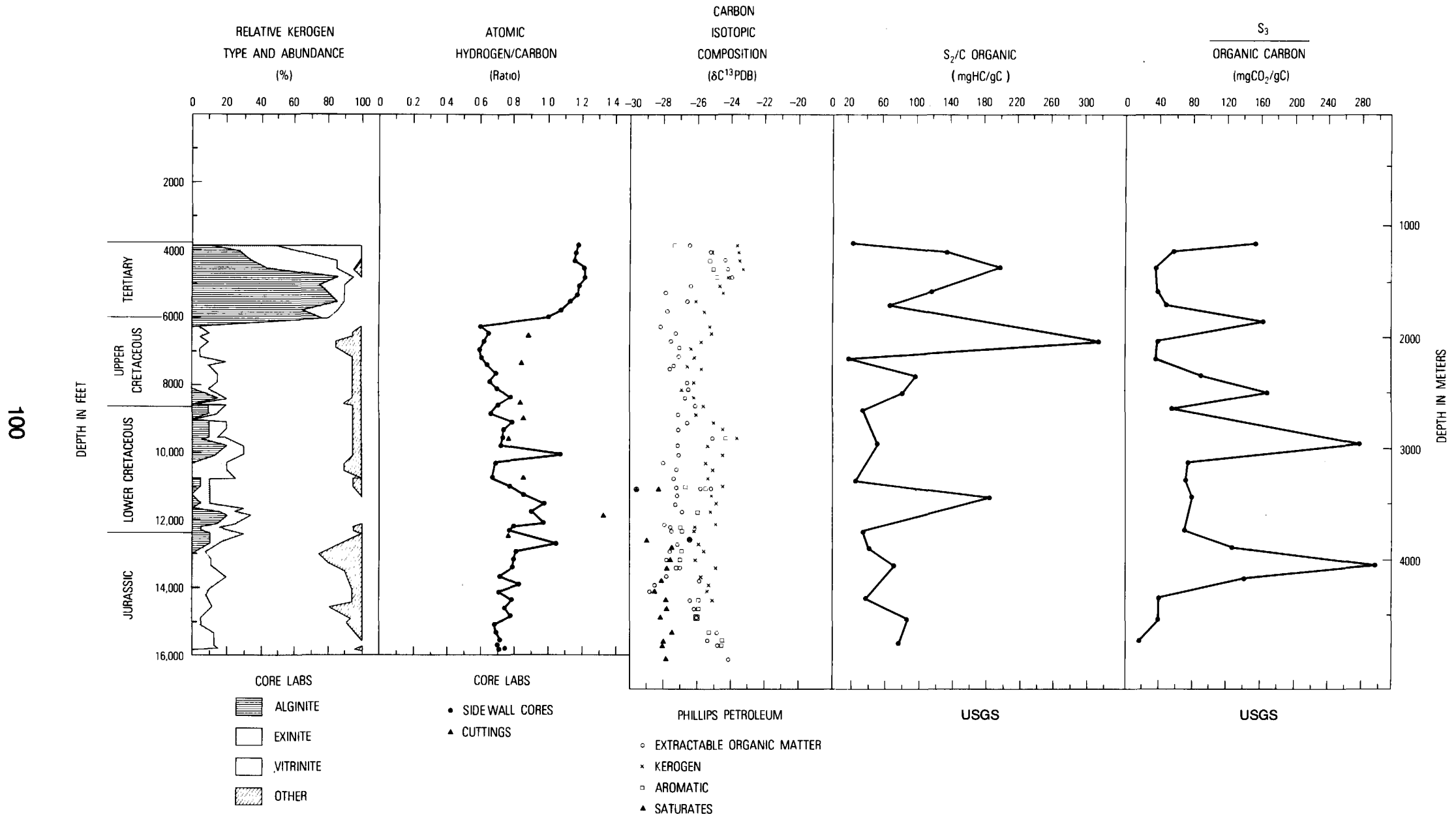

Figure 37.--Summary profile of indicators of types of organic matter present in the COST No. B-3 well, as a function of depth. 


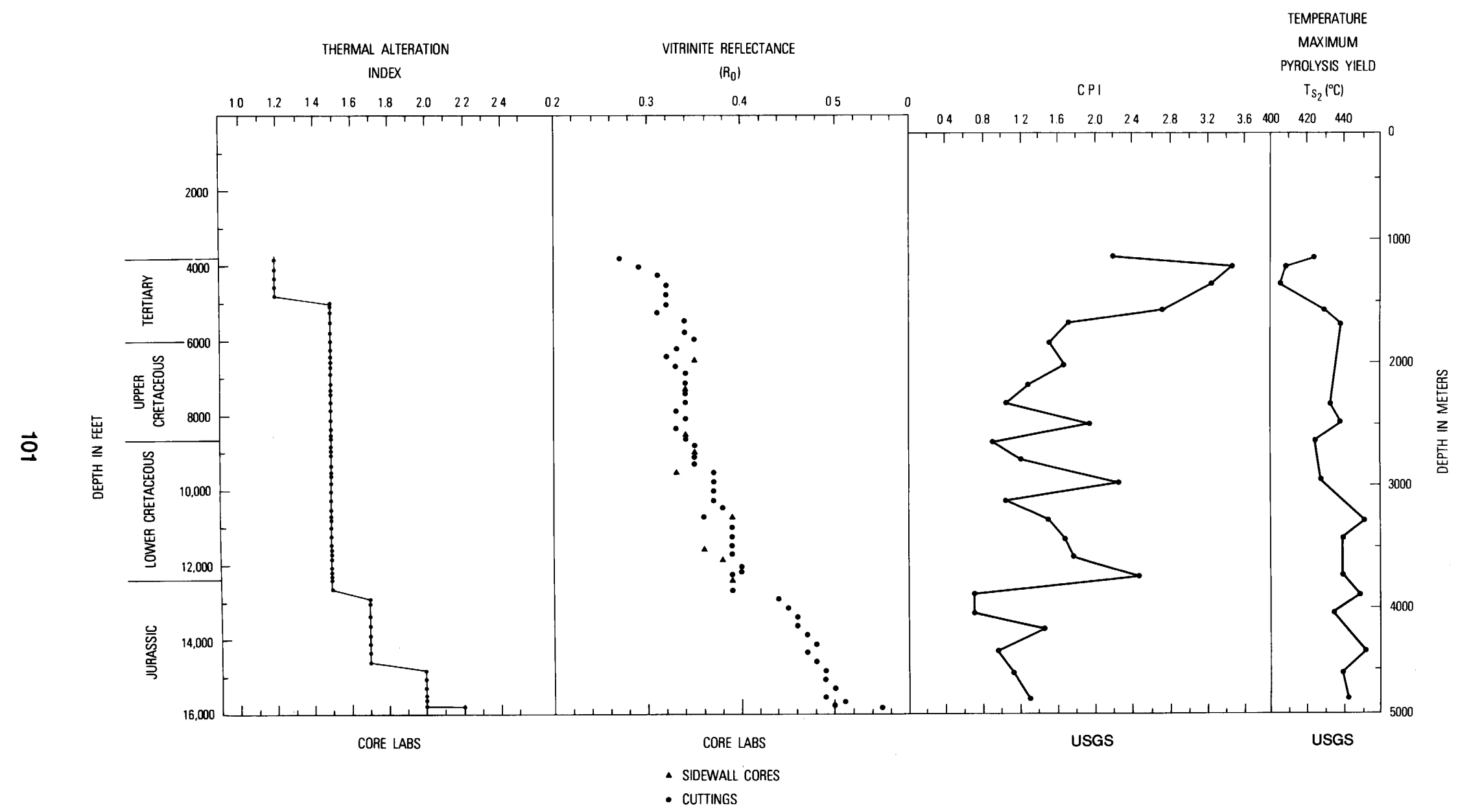

Figure 38.--Maturity profiles of organic matter as a function of depth in samples from the COST No. B-3 well. 
sources. The wide range and inconsistency in the stable-carbon-isotope ratios may indicate that the kerogen and extractable organic matter in the Tertiary secion have unrelated genetic origins, indicating that the extractable hydrocarbons were not derived by thermal processes ( $f 1 g \cdot 37$ ).

The TAI values range from 1.2 to $1.5 .$, and the vitrinite-reflectance values span 0.26 to 0.35 percent. Thermally immature extractable organic matter and kerogen are also suggested by CPI ratios that range from 3.5 to 1.7 and temperatures of maximum pyrolysis yield $\left(\mathrm{T}_{\mathrm{S}_{2}}\right)$ that vary from 757 to $817^{\circ} \mathrm{F}$ (403 to $436^{\circ} \mathrm{C}$ ) (f $\mathrm{ig}$. 38).

\section{Upper and Lower Cretaceous}

The kerogens of the Upper and Lower Cretaceous intervals are composed predominantly of exinite and vitrinite. Much smaller amounts of alginite are present here relative to amounts in the overlying Tertiary sediments. The atomic-hydrogen to carbon ratio varies from 0.6 to 0.8 , which is characteristic of hydrogenpoor, humic (Type III) kerogens. Exceptions to this trend are those samples at approximately $10,000 \mathrm{ft}(3,048 \mathrm{~m}), 11,500 \mathrm{ft}(3,505 \mathrm{~m})$, and 12,000 ft $(3,658 \mathrm{~m})$ that contain a slight enrichment in the hydrogen-rich type of kerogens. For the major part of the Cretaceous section, the relative kerogen abundance and classification show the presence of the Type-III kerogens; these are gas-prone and are not favorable for ofl generation. This humic (Type III)-kerogen predominance is consistent with the therma1-pyrolysis average convertibility of 8.46 (weight percent) for the total Cretaceous interval. For these predominantly humic (Type III) Cretaceous kerogens, the stable-carbonisotope ratio ranges from 23.5 to 27 permil and differs very little from the algal (Type I) kerogens of the overlying Tertiary (fig. 37).

The Cretaceous section is characterized by a constant TAI of 1.5 and vitrinite-reflectance $\left(R_{0}\right)$ values that increase continuously from 0.32 to 0.40 percent. The CPI rat1o varies inconsistently from 0.9 to 2.5 . The temperatures of maximum pyrolysis yleld vary from 806 to $817^{\circ} \mathrm{F}\left(430\right.$ to $\left.436^{\circ} \mathrm{C}\right)$, except for those samples at 8,700 ft $(2,653 \mathrm{~m})$ with a temperature of $790^{\circ} \mathrm{F}\left(421^{\circ} \mathrm{C}\right)$, at $9,700 \mathrm{ft}(2,957$ m) with a temperature of $795^{\circ} \mathrm{F} \quad\left(424^{\circ} \mathrm{C}\right)$ and at $10,800 \mathrm{ft}(3,292 \mathrm{~m})$ with a temperature of $838^{\circ} \mathrm{F}$ $\left(448^{\circ} \mathrm{C}\right)$. These thermal maturation parameters suggest that the organic matter present in the Cretaceous section has not yet reached sufficient thermal maturity to be capable of generating and expelling hydrocarbons (f1g. 38).
Upper Jurassic

The Upper Jurassic sediments penetrated in the $\operatorname{cosT}$ No. B-3 well have kerogsns that are predominantly exinite and vitrinite. These humic and woody kerogen types are very similar to the kerogens present in tho overlying cretaceous sediments. The atomic-hydrogen to carbon ratio for the Jurassic kerogens averages 0.77, which is consistent with a Type-III classification. Additional evidence for an interpretation of a predominantly hydrogen-poor type of kerogen is provided by the average therma1-pyrolysis-convertibility ratio of pyrolytic hydrocarbon to organic carbon of 6.05 (weight percent). The wide range of the stablecarbon-isotope ratios, from 2.5 to 3.5 (permil), between the kerogen, saturated paraffins, aromatics, and total extractable organic matter, suggest that the extractable liquid hydrocarbons are not genetically related to the kerogens (ffg. 37).

Significant and consistent increases in the degree of thermal maturity are indicated by TAI values that vary from 1.5 at $12,750 \mathrm{ft}(3,886 \mathrm{~m})$ to 2.2 at $15,820 \mathrm{ft}(4,822 \mathrm{~m})$ ant vitrinitereflectance values that range from 0.39 to 0.55 percent. Although the $R_{0}$ values are less than the 0.6 percent commonly cited as required for the onset of peak hydrocarbon generation, there is some reason to belleve that the data reported are blased toward low values (Smith, 1979). For this reason, the other maturity inficators are welghted more heavily in our interpretation. The CPI odd-even ratio and the temperature of maximum pyrolysis yield varies from 0.69 to 1.46 and from 806 to $838^{\circ} \mathrm{F}\left(430\right.$ to $\left.448^{\circ} \mathrm{C}\right)$, respectively (table 3). Such consistent agreement between parameters probably indicates the onset of thermal maturity at depths below $14,900 \mathrm{ft}(4,542 \mathrm{~m})$.

\section{Possible Effects of Mud Additives on Source-Rock Interpretation}

Figure 39 shows the saturated paraffinnaphthene hydrocarbon gas chromatograms for the major mud additives used during the drilling of the $\operatorname{cosT}$ No. B-3 well. The normal aliphatic hydrocarbons extracted from the raw stock of Spersene (1ignosulfonate), and barite ( $\mathrm{BaSO}_{4}$ ) have similar gas-chromatographic characteristics that suggest a common component. Both have a well-resolved aliphatic component ranging from $\mathrm{n}-\mathrm{C}_{16}$ to $\mathrm{n}-\mathrm{C}_{28}$ and having a maximum peak intensity at $\mathrm{n}-\mathrm{C}_{18}$, and a moderately well developed, unimodal unresolved complex mixture. The spersene and barite have totalorganic-carbon (weight percent) values of 37.5 
CARBON NUMBER

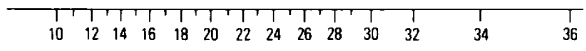
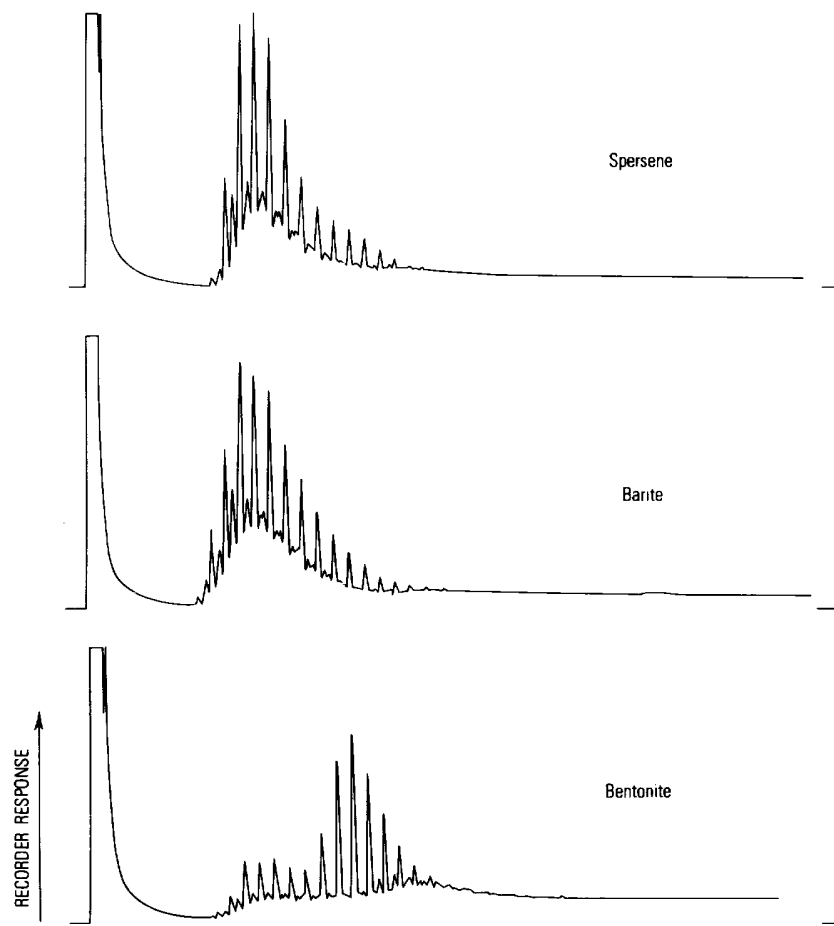

TIME-TEMPERATURE

Figure 39.--Gas-chromatographic analyses of additives to the mud drilling system, COST No. B-3 we11.

and 0.36 respectively (table 7$)$. The source of the normal alkane hydrocarbons in these additives is unknown; however, they are believed to be related to a petroleum-based substance, possibly a light-oil or diesel component, which may have been introduced during the mudadditive-preparation process either at the manufacturing stage or during the time the mud was mixed on the drilling platform.

The saturated paraffin-naphthene gas chromatogram of the montmorillonitic bentonite (total organic carbon, 0.2 weight percent) is characterized by the domination of the resolved

Table 7.--Analytical data for extmactable organic matter in drilling-mud additives used in the COST No. $B-3$ well

[-- Ind1cates no data]

\begin{tabular}{|c|c|c|c|c|}
\hline Additive & $\begin{array}{l}\text { Total } \\
\text { organtc } \\
\text { carbon } \\
\text { (we1ght } \\
\text { percent) }\end{array}$ & $\begin{array}{c}\text { Al1phat 1c } \\
\text { (ppm) }\end{array}$ & $\begin{array}{l}\text { Aromat Ic } \\
\text { (ppm) }\end{array}$ & $\begin{array}{l}\text { NSO } \\
\text { (ppm) }\end{array}$ \\
\hline $\begin{array}{l}\text { P1pe dope- } \\
\text { Bentonite- } \\
\text { Carboxymethylcellulose- } \\
\text { Spersene- } \\
\text { Bar1te }\end{array}$ & $\begin{array}{c}\overline{0.2} \\
33.5 \\
37.5 \\
0.36\end{array}$ & $\begin{array}{r}312,567 \\
4.4 \\
148.3 \\
11.4 \\
71.9\end{array}$ & $\begin{array}{r}71,753 \\
2.8 \\
69.1 \\
1.9 \\
26.6\end{array}$ & $\begin{array}{r}4,247 \\
103.9 \\
237.9 \\
209.5 \\
63.9\end{array}$ \\
\hline
\end{tabular}

aliphatics over a weakly developed unresolved envelope. The aliphatics range from $n-C_{18}$ to $n-$ $\mathrm{C}_{28}$, with the longer chain $\mathrm{n}-\mathrm{C}_{22}$ to $\mathrm{n}-\mathrm{C}_{27}$ hydrocarbons as the dominant molecular species. Both casing-thread dope and the carboxymethylcellulose (CMC), which has a totalorganic-carbon content of 33.5 weight percent, have signatures that show the predominance of a we11-developed, unresolved, complex mixture but with very poorly developed, resolved, normal aliphatic components. The unresolved envelope of the pipe dope reaches its maximum at $\mathrm{n}-\mathrm{C}_{29}$, whereas the maximum is at $n-C_{21}$ for tho CMC additive.

The well-cutting samples selected to be analyzed for the COST No. B-3 well source-rock profile were thoroughly hand washed and extraneous forelgn particles were eliminated before the samples were analyzed. Excert for those specific intervals for which nonindigenous liquid hydrocarbons were discussed, the effect of the mud additives may be minimal on the basis of the relatively immature character of the $\mathrm{C}_{15^{+}}$ gas chromatograms, and the relatively consistent 
levels of total organic carbon (fig. 39 and table 7). However, the $n-C_{4} / n-C_{7}$ ratios would suggest, if the value of untty or below for the ratio is accepted as a fingerprint for diese1fuel contamination, that nonindigenous anthropogenic hydrocarbons might be present in the interval from $3,800 \mathrm{ft}(1,158 \mathrm{~m})$ to $8,200 \mathrm{ft}$ $(2,499 \mathrm{~m})$. The possibility that the mud additives employed in the COST No. B-3 well may have played an influential role by partially masking the indigenous hydrocarbons should not be excluded in the interpretation of source-rock richness, quality, and maturation. However, their influence is believed to be minimal in the B-3 well. A possible solution to the problem of mud-additive effects on source-rock interpretation and evaluation would be to label each additive with a distinctive "tracer" that would allow a diagnostic signature to be detected whenever mud additives have not been completely removed in efther well cuttings or sidewall cores.

\section{CONCLUSIONS AND IMPLICATIONS FOR PETROLEUM GENERATION}

The Tertiary section in the COST No. B-3 we11 $(3,800-6,040 \mathrm{ft} ; 1,158-1,841 \mathrm{~m})$ has an above-average total-organic-carbon content ( 1.5 percent) and kerogens that are mainly composed of the hydrogen-rich (Type I), marine algal variety. Results of both optical and chemical measurements indicate that the Tertiary kerogens are thermally immature. The molecular compositions and bolling-point ranges of the saturated $\mathrm{C}_{15}+$ liquid paraffin-naphthene hydrocarbons also are consistent with thermally immature extractable organic matter. The shallow gas occurrence at about $4,000 \mathrm{ft}(1,219$ m) is predominantly methane and has a relatively low percent gas wetness; it 18 not belleved to be of thermogenic origin.

The Upper Cretaceous section down to a depth of $7,500 \mathrm{ft}(2,286 \mathrm{~m})$ may have been affected by mud additives. Below $7,500 \mathrm{ft}$ $(2,286 \mathrm{~m})$, the effects of mud additives do not appear to be significant factors in influencing source-rock richness or maturity interpretations. In contrast with the overlying Tertiary section which contains predominantly hydrogen-rich kerogens, the Upper and Lower Cretaceous interval from 6,040 to $12,400 \mathrm{ft}$ $(1,841$ to $3,780 \mathrm{~m})$ contains hydrogen-lean kerogens that are classified primarily as exinite and vitrinite (Type III). The molecular compositions of the saturated paraffin-naphthene hydrocarbon mixtures are unlike the composition of petroleum, and the pyrolysis characteristics also indicate that the Cretaceous section is thermally immature. The very low total gas concentrations, coupled with the low values for optical-maturity indicators, suggest that the temperatures required to initiate the petroleumhydrocarbon-formation processes have been of sufficient intensity or duration to have generated or expelled liquid and (or) gaseous hydrocarbons from any potential sourse rocks in the Cretaceous section.

The Upper Jurassic interval $(12,400-15,820$ $\mathrm{ft}$; $3,780-4,822 \mathrm{~m})$ penetrated in the $\mathrm{B}-3$ wel1 has total organic-richness characteristics that indicate moderate to good source-rock potential. The kerogens are composed predominantly of the gas-prone (Type III) exinite and vitrinite varieties. The $\mathrm{C}_{15}{ }^{+}$ liquid-hydrocarbon mixtures show an increasing resemblance to petroleum below 14,90$) \mathrm{ft}(4,542$ $m$ ), as indicated by a systematic decrsase in the magnitude of the unresolved envelope and a relative increase in the concentration of the lower molecular weight, resolved, saturated paraffin-naphthenes. A significant increase in the concentration of $C_{1}$ to $C_{4}$ light hvdrocarbons and in the gas-wetness percentage $\varepsilon 180$ occurs below 14,300 ft $(4,359 \mathrm{~m})$, indicating that thermal maturation of the organic matter has started. Optical and other chemical-maturity indicators are consistent w:th this interpretation. Although conditions favorable for petroleum generation are reached in the Upper Jurassic section at depths kelow about $15,000 \mathrm{ft}(4,572 \mathrm{~m})$ in the COST No. B-3 we11, the organic matter is not of the type that yields significant amounts of liquid hydrocarbons (o11). Although the concentrations of organic matter are adequate for hydrocarbon generation, the types of organic matter present indicate that this section is more 11kely. to generate gas than oil. 
GEOPHYSICAL STUDIES

Davld J. Taylor and Robert C. Anderson

\section{SYNTHETIC SEISMOGRAM}

Synthetic selsmic traces were computed using the Interval-transit-time $10 \mathrm{~g}$ and density $10 \mathrm{~g}$ from the COST No. B-3 well. Velocity Information from the interval-transit-time $10 \mathrm{~g}$ was also used to generate cross-plots of depth versus two-way travel time and of average and RMS velocity versus two-way travel time.

Data for these computations were obtained directly from the digital well-log tape recorded at the COST No. B-3 well site during the logging. A minor amount of editing was performed on the interval-transit-time curve before the synthetic-seismogram traces were generated.

The velocity and density curves were converted to a linear time scale through integration of the interval-transit-time welllog curve. The product of the velocity curve and the density curve produces the acousticimpedance trace, from which the reflectioncoefficient trace is computed according to:

$$
r(t)=\frac{r(t+1) V(t+1)-r(t) V(t)}{r(t+1) V(t-1)+r(t) V(t)},
$$

where $r(t)$ is the reflection coefficient at time $t, V$ is velocity, $r$ is density, and the index " $t$ " denotes the two-way-time position of rock layers above and below the reflecting horizon with respect to sea level. The computation of $r(t)$ for each rock-layer interface yields a reflection-coefficlent trace, consisting of a time series of sharp pulses. The magnitude represents the strength of the reflecting horizon, and the time index is its position in two-way normal-incidence travel time. The sign of the reflection coefficient represents the polarity of the rock layers, which is an indication of whether the selsmic wave is leaving a rock layer that is acoustically harder or softer than the one it is entering. This method for generating synthetic seismograms ignores transmission losses, absorption losses, and any effects of multiples.

To complete the synthetic seismogram, an arbitrary wave pulse, or wavelet, is convolved with the reflection-coefficient serles to match the wave form and frequency characteristics of the seismic data. The resulting trace can then be used to correlate geologic formations to their corresponding expression in seismic field data. For this study, the waveforms applied were symmetric bandpass wavelets with differentfrequency passbands. This approach shows which seismic frequencies are required to be present in the field data in order to allow detection of a particular geologic formation.

A set of synthetic selsmograms generated using the product of velocity and density (acoustic impedance), and with varying bandpass filters applied, is shown in figure 40. Bandpass-filter cutoffs are listed above each seismogram group. Polarity of these seisnograms is conventional: a positive reflection amplitude represents a transition of lower to higher acoustic impendance between rock layers. Noise or multiple reflections ware not added to these seismograms.

In addition to this group of synthetic seismograms, additional sets of synthetics were computed using the velocity data alone and then the density data alone. These seismograms, using the same bandpass filters that were applied to the seismograms in figure 40 are shown in figures 41 and 42 . These seisnograms were constructed to show the individual contributions of velocity and density to the seismic trace. The amplitude of the traces in these figures were scaled to a common levis and, therefore, do not accurately represent the true relative amplitude strength of each trace. However, the seismograms do show where the important acoustic boundaries are located and which acoustic property is contributing to the total seismogram.

The best correlation of the synthetic selsmogram (generated from the CosT No. B-3 well) to fleld data occurs using the $8-35 \mathrm{~Hz}$, filtered, synthetic selsmogram developed from the velocity-density product, and having the polarity inverted. This compensation for polarity is common in seismic interpretation, as it is possible for polarity to be inverted in the phases of recording or processing selsmic data. Figure 43 shows the 8-35 $\mathrm{Hz}$ synthetic seismogram selected for correlation to the field data, discussed in the next section, along with 


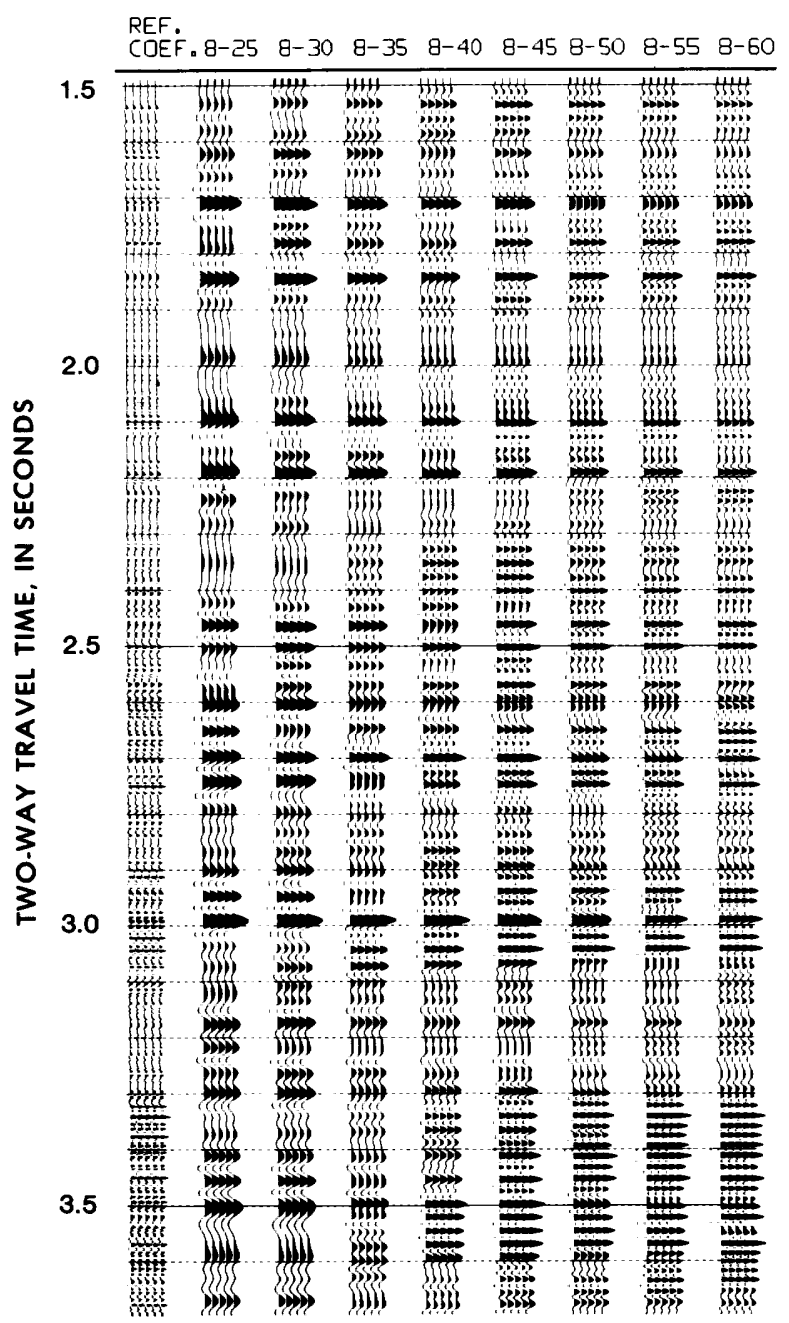

P1gure 40.--Reflection-coefficient trace (at the far left), constructed from the cosT No. B-3 interval-transit-time and density-log curves, and several bandpass-filtered versions of the reflection-coeffictent trace. The upper and lower frequencles of the bandpass filters are listed above each group. Polarity for these synthet1c selsmograms is conventional: a positive reflection (deflection to the right) represents the transition from a layer with lower acoustic impedance to a deeper layer with higher acoustic impedance.

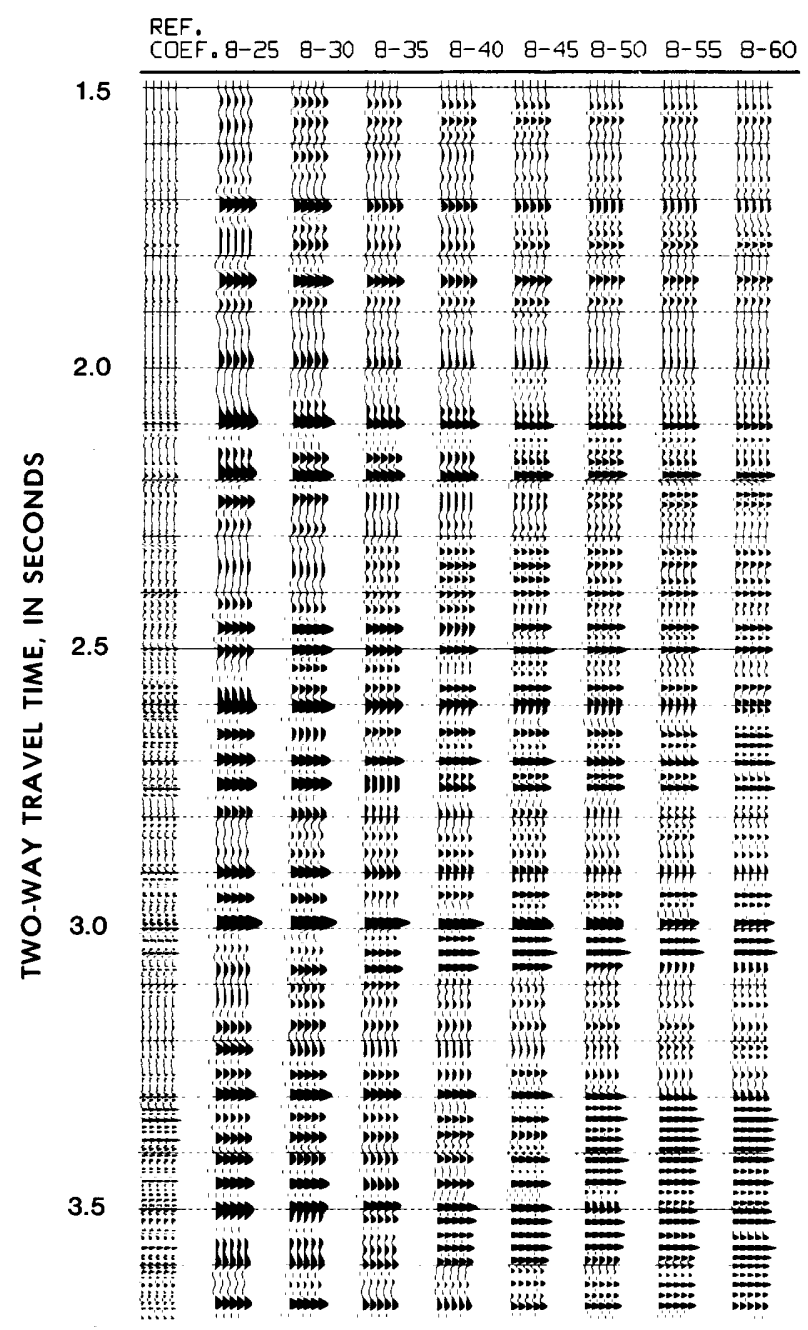

FIgure 41.--Reflection-coefficlent trace and filtered versions constructed from the COST No. B-3 well ustrg only the velocity information from the interval-transit-time log. Filter cutoffs and polarity are the same as those used in f1gure 40. The upper and lower frequencles of the bandpass filters are listed above each group. Polarity for these synthet1c selsmograus is conventional: a positive reflection (deflection to the $r$ ight) represents the transition from a layer with lower acoustic Impedance to a deeper layer with higher acoustic Impedance.

Figure 42.--Reflection-coefficient trace and filtered versions constructed using only density $D$ information. Filter cutoffs and polarity are the same as in figure 40 . The upper and lower frequencies of the bandpass filters are listed above each group. Polarity for these synthetic seismograms is conventional: a positive reflection (deflection to the right) represents the transition from a layer with lower acoustic imnedance to a deeper layer with higher acoustic impedance. 
Figure 43.--Synthetic selsmograms constructed $D$ from velocity and density data from the cosT No. B-3 well. These selsmograms have been filtered using an 8-35 $\mathrm{Hz}$ bandpass filter and reversed in polarity to match the selsmic fleld data shown in figure 46. From the left, the first group of traces represents a synthetic trace constructed from velocity data alone, and the second group is a synthet1c trace constructed using density data alone. The right-most group is the synthetic trace constructed from the velocitydensity product, or acoustic Impedance.

REF.

COEFं.8-25 $\quad 8-30 \quad 8-35 \quad 8-40 \quad 8-45 \quad 8-50 \quad 8-55 \quad 8-60$

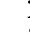

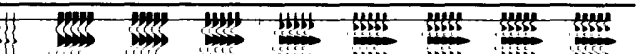

2.0

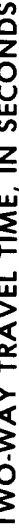

2.5

3.5

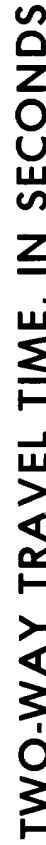

UEL. DENS. UEL. ONLY ONLY DENS。

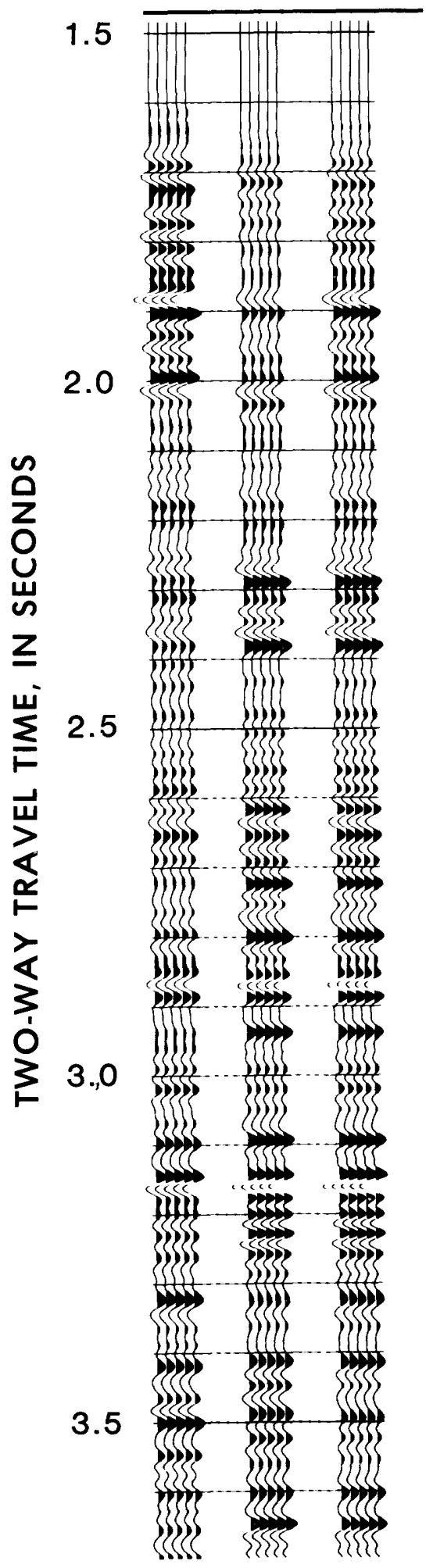


VELOCITY, IN KILOMETERS PER SECOND

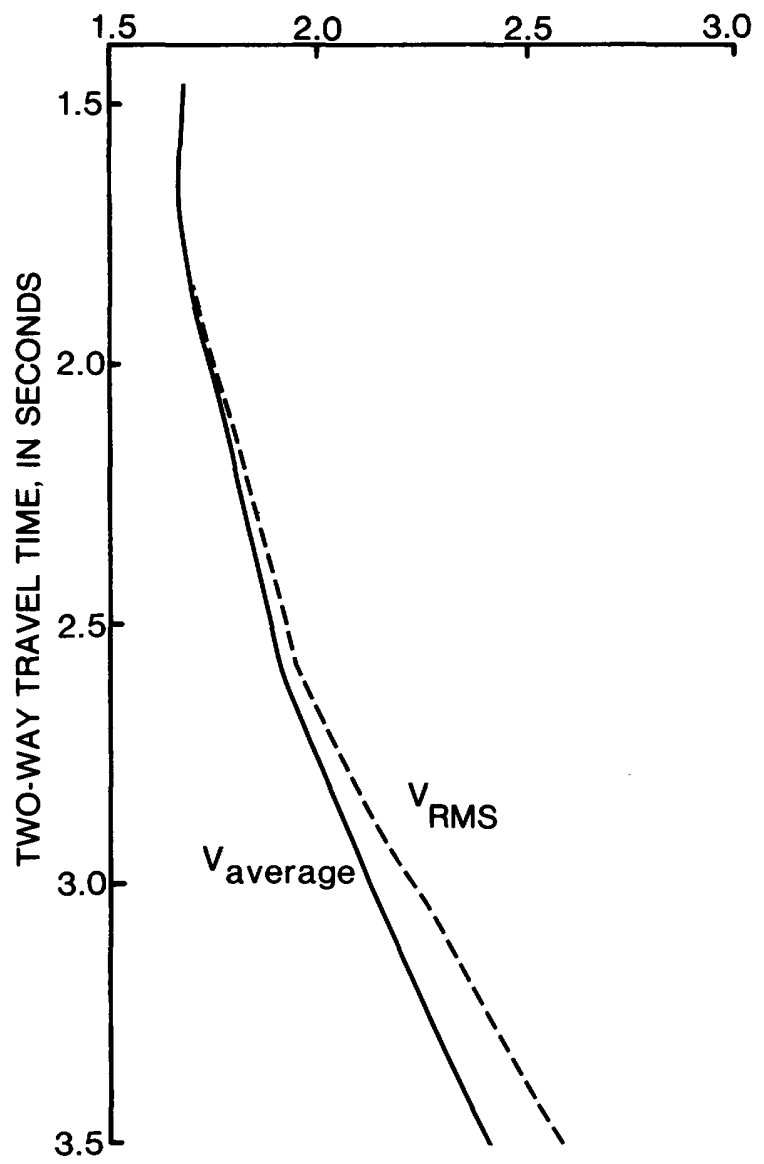

Figure 44.--Two-way travel time from sea-level datum as a function of average velocity and root-mean-square (RMS) velocity.

the velocity-on1y and density-only synthetic seismograms. All of these traces in this figure have been reversed in polarity.

Velocity information useful to seismic-data interpretation can also be extracted from welllog data. Average velocity versus two-way travel time, shown in figure 44, can be used to convert the reflection time of a formation from selsmic field data to a function of depth below the surface. Average velocities can also be used for migration of seismic data in areas of geologic structure and faulting. Root-mean-square (RMS) velocity, shown in the same figure, can be used to determine the proper correction for normal-moveout in the stacking of offset seismic traces. RMS velocities, however, are only usable in areas where changes in lateral velocity are not great. Finally, the relationship between two-way travel time and depth is shown in figure 45. Major age boundarles plotted in the figure are from Amato and Simonis (1979).

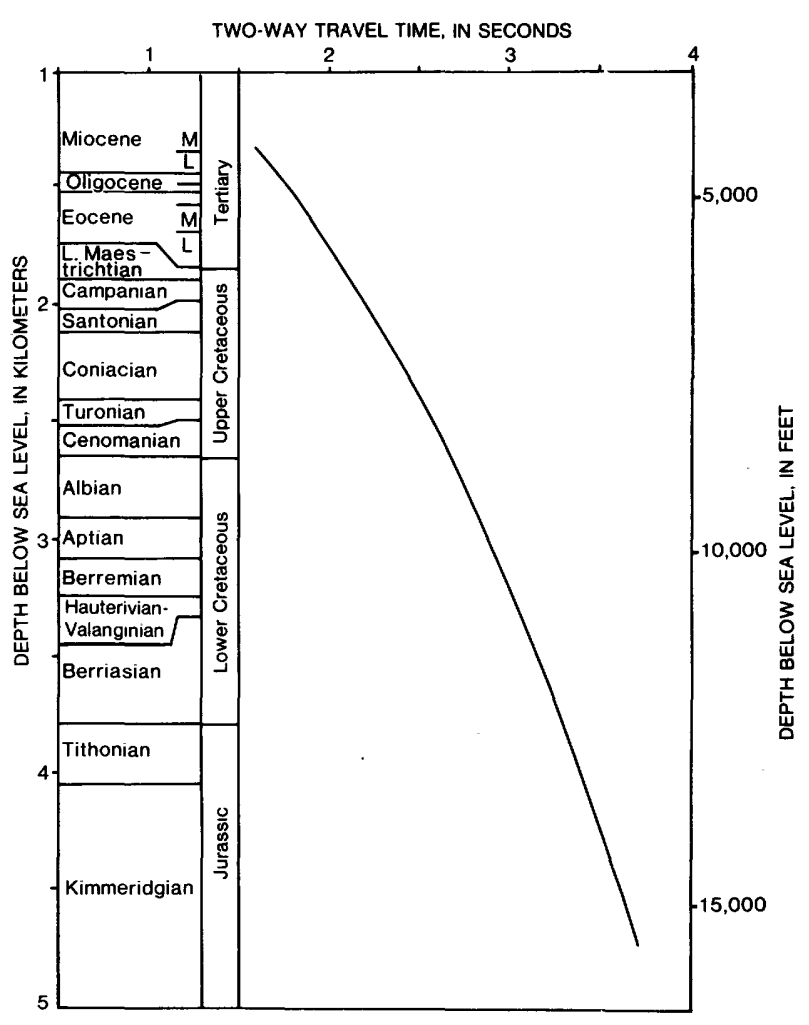

Figure 45.--Two-way travel time below sea-level datum as a function of depth. Ages are from Amato and Simoris (1979).

\section{SEISMIC DATA - LINE 25}

In order to tie the COST No. $\mathrm{B}-3$ well into the grid of regional seismic data, Selsmic Line 25 was used. Line 25 is a 48-fold, common-depth-point (CDP), seismf.c-reflection line and, at this date, is the closest USGS line to the CosT No. B-3 well. The CosT No. B-3 well is roughly $7 \mathrm{mi}(11 \mathrm{~km})$ along strike and northeast of shotpoint number 2885 of Line 25 .

Line 25 was acquired for the USGS by Geophysical Services, Inc. (GSI), during the summer of 1978. Following the acquisition of the selsmic data, GSI performed data processing of the raw fleld data to a final stacked section. This processing included demultiplexing, velocity analysis every $2 \mathrm{mi} \mathrm{(3}$ $\mathrm{km}$ ), normal-movement (NMO) corrections, 48-fold horizontal stacking, time-variant predictive deconvolution for removal of multiples, bandpass filtering, and trace-amplitude equalization.

Figure 46 is a portion of Line 25 surrounding the projected tie with the COST No. B-3 we11. Evident from this figure are several good correlations between the synthetic selsmogram and the seismic data. Table 8 lists several of the better correlations between the synthetic seismogram and the seismic data, along with age dates taken from Amato and Simonis 


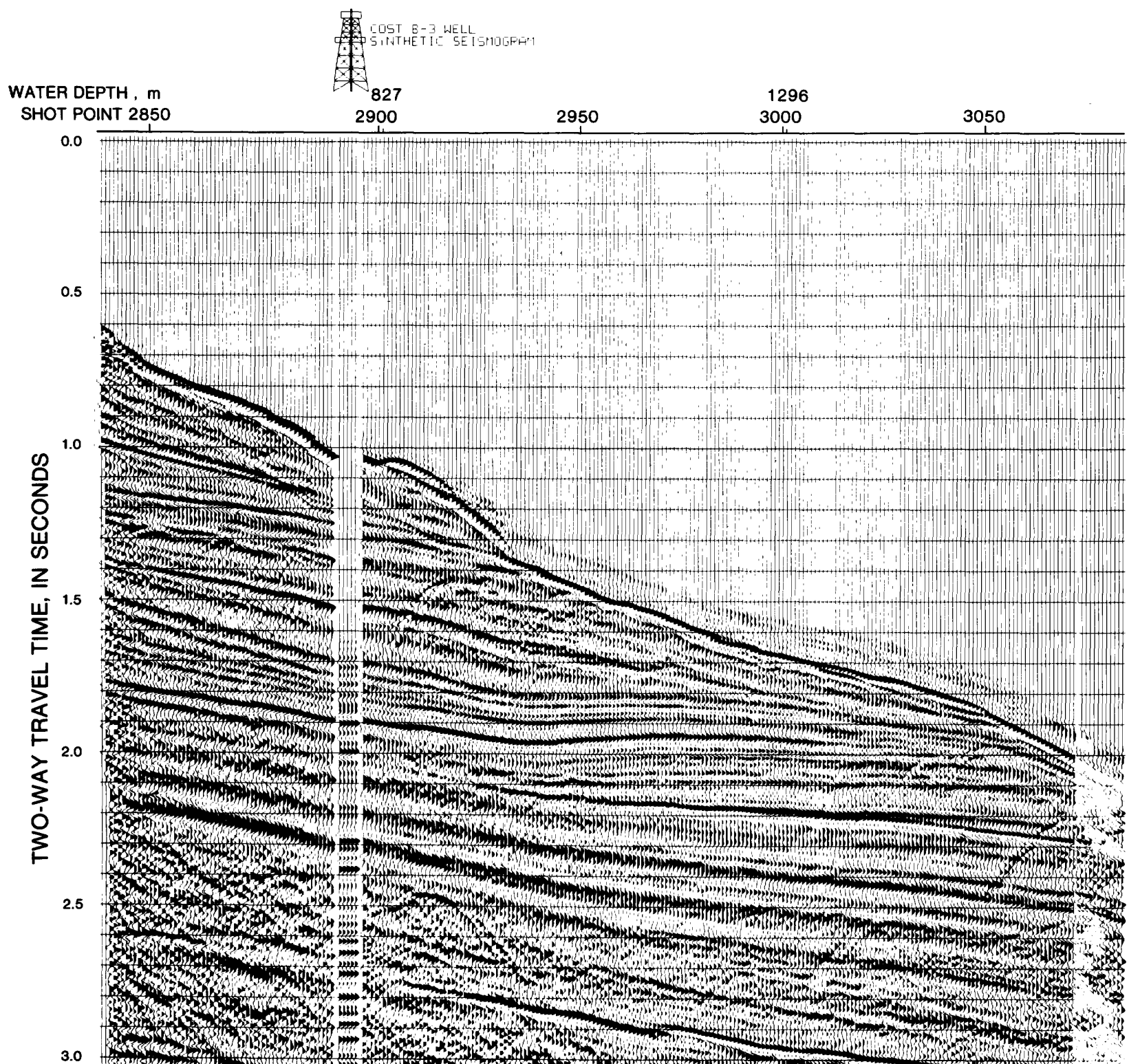
Bry

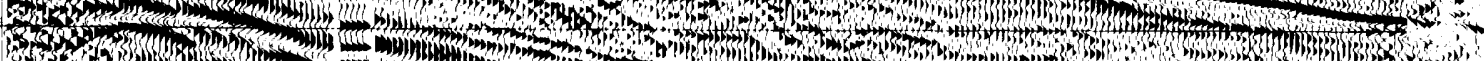

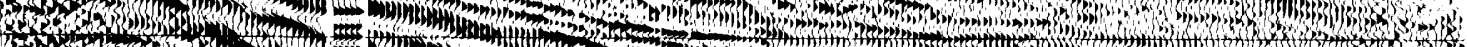

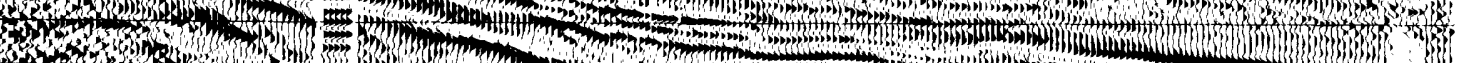

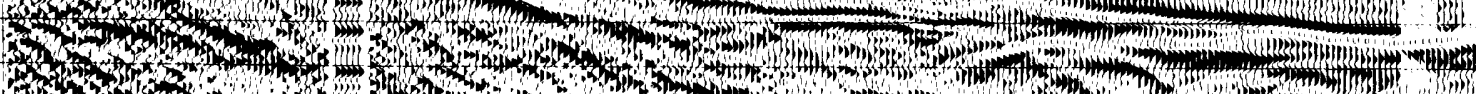

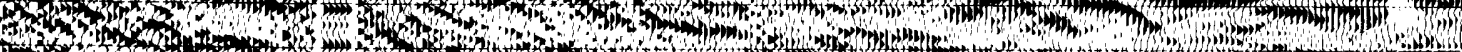

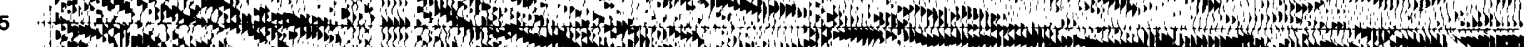

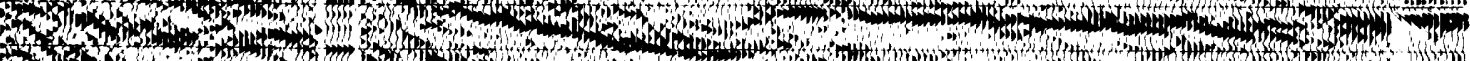

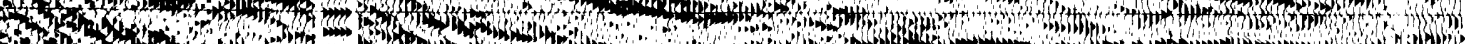

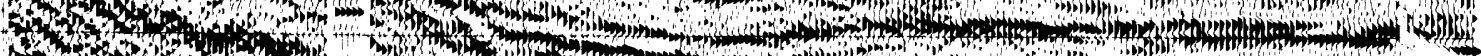

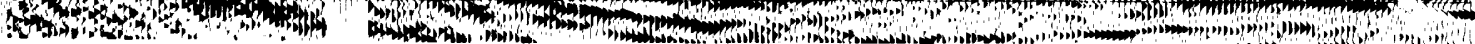

Figure 46.--A portion of USGS CDP reflection Line 25 and the bandpass-filtered (8-35 Hz), reflection-coefficient trace projected along strike from the COST No. B-3 well. The synthet1c selsmogram has been time shifted to account for dip between the well and sefsmic line and has been reversed in polarity to match the polarity of the seismic field data. This synthetic seismogram is also shown in figure 43.

(1979). Figure 47 shows these age correlations interval-velocity log of the cosT No. B-3 and lithologic descriptions plotted against the well. 
INTERVAL VELOCITY, IN KILOMETERS PER SECOND

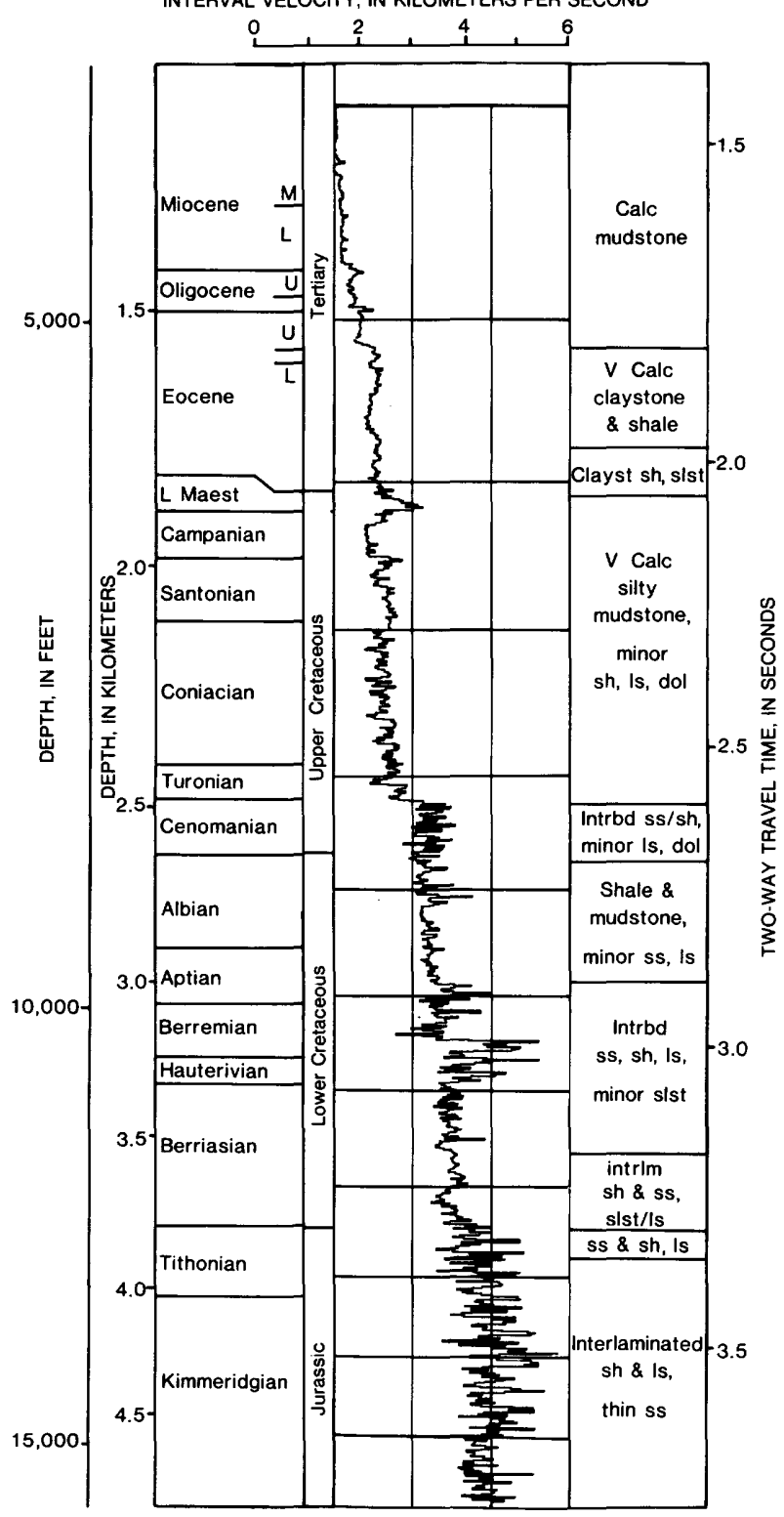

Figure 47.--Interval velocity as a function of depth below sea level and two-way travel time. The correlations and 1ithology are from Amato and Simonis (1979).
Table 8.--Correlations between the COST No. B-3 well and USGS Seismic Line 25

\begin{tabular}{|c|c|c|c|}
\hline \multirow{2}{*}{$\begin{array}{l}\text { Two-way } \\
\text { travel time } \\
\text { (s) }\end{array}$} & \multicolumn{2}{|c|}{ Depth } & \multirow[b]{2}{*}{ Age $^{1}$} \\
\hline & Feet & Meters & \\
\hline $\begin{array}{l}1.745 \\
1.805 \\
1.900 \\
2.090 \\
2.300 \\
2.700 \\
3.160 \\
3.405 \\
3.600\end{array}$ & $\begin{array}{r}4,856 \\
5,052 \\
5,348 \\
6,070 \\
6,923 \\
8,694 \\
11,320 \\
12,960 \\
14,534\end{array}$ & $\begin{array}{l}1,480 \\
1,540 \\
1,630 \\
1,850 \\
2,110 \\
2,650 \\
3,450 \\
3,950 \\
4,430\end{array}$ & $\begin{array}{l}\text { Within late oligocene. } \\
\text { Within late Focene. } \\
\text { With1n late Eocene. } \\
\text { Late Cretacecus boundary. } \\
\text { Santonlan-Corlacian boundary. } \\
\text { Early Cretaceous boundary. } \\
\text { W1th1n Berriasian. } \\
\text { Within Jurassic-Tithonian. } \\
\text { W1thin Jurassic-Kimmeridgian. }\end{array}$ \\
\hline
\end{tabular}

${ }^{1}$ Data from Amato and Simonis, 1979.

.




\section{SEISMIC STRATIGRAPHY IN THE VICINITY}

OF THE COST NO. B-3 WELL

John S. Schlee and John A. Grow

\section{INTRODUCTION}

The CosT No. B-3 well is situated in the vicinity of a grid of multichannel seismicreflection profiles and shallower drill holes (fig. 48); the holes have been described by Scholle (1977), Poag (1978, 1979), Hathaway and others (1976, 1979), and Amato and Simonis (1979). The seismic-reflection profiles have been studied by Grow and others (1979), Klitgord and Behrendt (1979), Schlee and others (1976, 1979), and Folger and others (1979).

The purpose of this paper is to describe the seismic stratigraphy adjacent to the COST No. B-3 well and to tie these observations to the lithology encountered in this and other nearby wells.

\section{SEISMIC STRATIGRAPHY}

As can be seen by the age and arrangement of key reflectors in figures 49 and 50 , the outer shelf and slope were built up during the Cretaceous and Jurassic. During the Cenozoic, intervals of progradation alternated with intervals of erosional retreat, and so the shelf-slope break, at present, is $12 \mathrm{mi}(20 \mathrm{~km})$ landward of where it was in the Early Cretaceous. Beneath the shelf, where the oldest reflectors can be distinguished, subsidence occurred mainly during the Jurassic and Late Triassic. Reflectors inferred to be Late Cretaceous and Tertiary are exposed along the present Continental slope (Weed and others, 1974), and a large sedimentary wedge of Miocene and younger age underlies the Continental Rise. Construction of the rise wedge has been discontinuous, as shown by the presence of apparent unconformities within it (fig. 50). Differential subsidence flanking the Early Cretaceous shelf edge (fig. 51) has created a broad slope "anticline" similar to that described by Lancelot and Selbold (1978) and Von Rad and Einsele (1980) in the Aatun basin off West Africa.

\section{REFLECTOR BOUNDARIES}

The character of the key reflectors (figs. $49,50,52$, and 53) changes from the shelf to the rise. In a study of reflectors beneath the shelf, Schlee (in press) showed that certain ones are associated with unconformities, and these have been used to delineate the major seismic-stratigraphic units. By tracing reflectors from onshore well and the $\operatorname{CosT}$ No. B2 well, the unconformities are enferred to occur in the late 0ligocene, at the base of the Tertiary, in the Confacian and the Cenonantan, and at the base of the Albian. Poag (this volume) has detected hiatuses on the Continental Shelf in the COST No. B-2 well at the base of the Quaternary, within the middle Miocene, at the base of the Miocene, between tho late oligocene and late Eocene, within the early Eocene, at the base of the Tertiary, betwsen the Maestrichtian and Campanian, between the Confacian and Turonian, and between the Trontan and Cenomanian. Below the Cenomanian, faunas are sparse and detection of erosional breaks is difficult. In the COST No. B-3 well, on the Continental slope, Poag finds disconformities between the middle and lower Miocene, tls late oligocene and late Eocene, the early Eocene and Maestrichtian, the Confacian and early Turonian, the Turonian and Cenomanian, and the Barremian and Hauterivian. Some of the breals, as detected seismically and dated by correlation with other wells, agree with Poag's studies and also with the relative-sea-level curve (fig. 50) of Vail and others (1977). The base of the Cretaceous sequence is in apparently conformable contact with Jurassic strata beneath the Outer Continental Shelf, and the contact is unconformable toward the inner part.

Under the Continental Rise (fig. 49), a few of the same reflectors are present: the Oligocene (Au), Tertiary-Cretaceous, Confacian, and Cenomanian, reflectors are present, although all but the Au horizon are conformable. Also present is Horizon (Tucholke and others, 


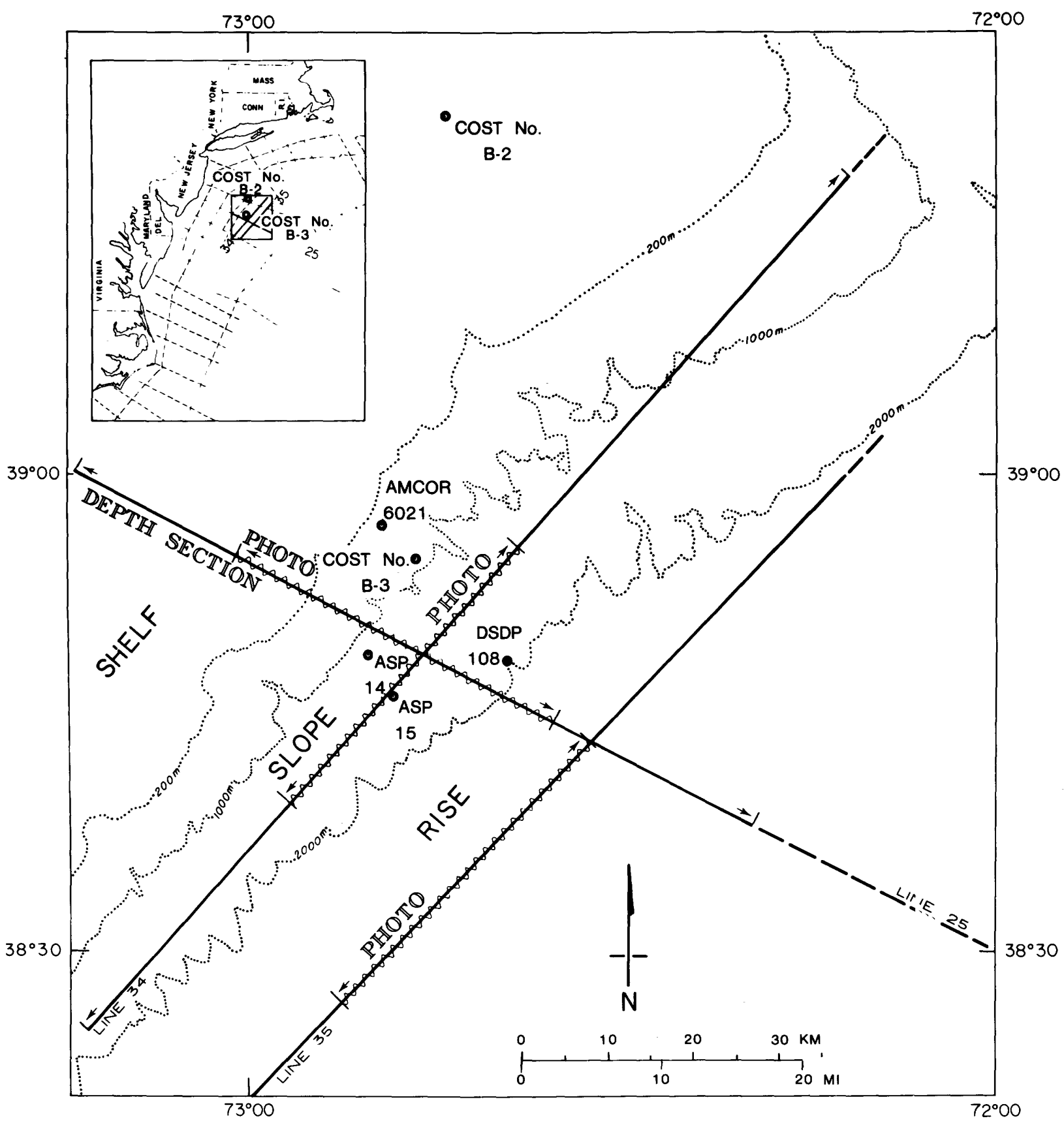

Figure 48.--Index map of seismic lines and drill holes in the vicinity of the $\operatorname{cosT}$ No. $B-3$ well. Inset locates area within the Mid-Atlantic Outer Continental Shelf. 


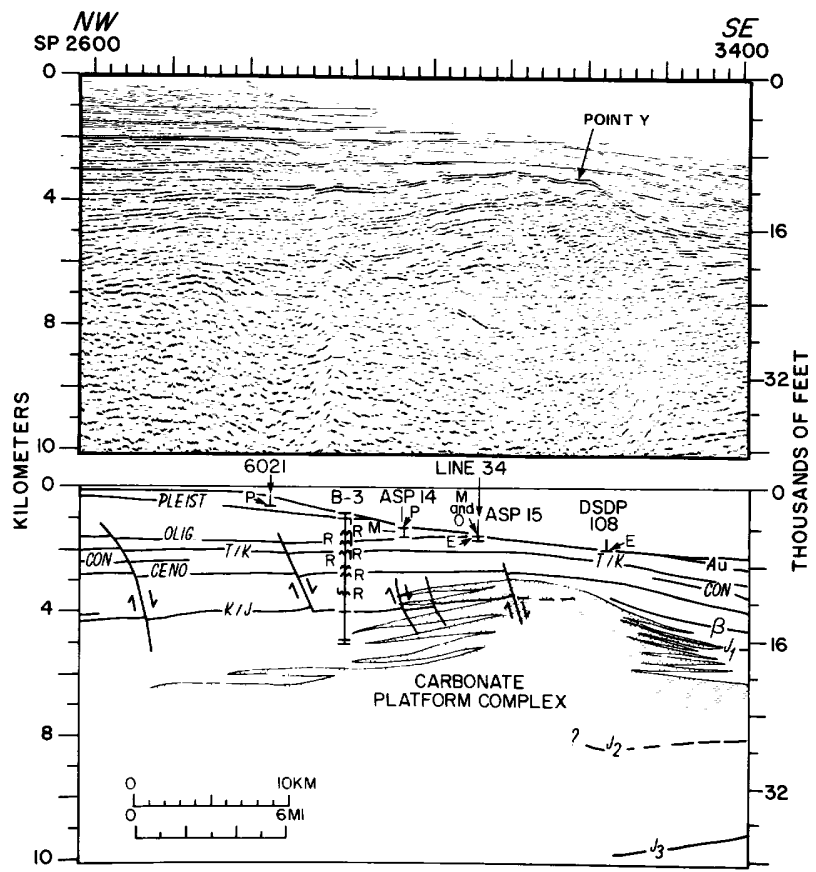

Figure 49.--Annotated depth section of a portion of USGS Selsmic Line 25 between shotpoints 2600 and 3400 . On the interpretation below the photo, reflectors beneath the shelf and upper slope probably approximate disconformities. Nearby well have been projected onto the depth section. Ages of sediments encountered in the shallow penetration holes are marked with a letter designation: P, Pleistocene; $M$, Mocene; E, Eocene. For the COST No. B-3 well, the Intervals of upper and lower slope conditions, as detected by Poag (this volume), are indicated by vertical bars to the right of the COST No. B-3 we 11 profection Iine; the one interval of nonmarine conditions is indicated by a vertical bar to the left of the we11. An " $R$ " near the CosT No. B-3 well Indicates a relative regression, and the wavy lines signify the positions of disconformitles detected by Poag (this volume). The broad outline of the carbonate platform-reef complex is shaded in the interpretation below the photo.

1979), Inferred to be the top of Neocomian limestones drilled in DSDP Hole 105 (400 mi (650 $\mathrm{km}$ ) southeast of the area). Two conspicuous unconformities are evident within the Continental Rise wedge (fig. 53) above the Au reflector.
On the seismic sections parallel to the slope (f1gs. 52 and 53), some of the same reflectors are evident within rocks of probable Cretaceous and Tertiary age. Horizor, so evident on Line 35 seaward of the carbonateplatform front ( $f 1 g \cdot 51$ ), does not carry through to Line 34 ( $\mathrm{f} / \mathrm{g} .49$ ), landward of the front. Instead, at about the same stratigraphic leve1, a horizon inferred to be near the top of the Hauterivian is evident (fig. 51; and Line 34, fig. 52).

Key reflectors (figs. 52 and 53) within the upper Continental Rise are mainly conformable, although Au has a relief of several hundred meters on Line 35 (fig. 53). However, older reflectors are flat and are distinguished by their continuity and moderate tc high amplitude. Further, they mark changes in the selsmic character between adjacent groups of less prominent reflectors.

\section{COREHOLE STRATIGRAPHY}

Projection of 11thology and ages of rocks drilled in nearby holes onto Line 25 (fig. 49) reveals the conditions under which the Continental Margin formed over the past 160 milition years (since Middle Jurassic). The COST No. B-3 well penetrated the upper $3 \mathrm{mi}(4.8 \mathrm{~km})$ of the upper slope ( $\mathrm{fig}$. 49); Upper JurassicLower Cretaceous rocks were deposited in a marine-shelf to nonmarine mileau, probably behind a reef complex (Poag, this volume; Valentine, this volume; Bebout and Lachance, 1979). Several regressions and transgressions affected the Cretaceous shelf, giving rise to hiatuses at the times already indicated. A major transgression occurred during the Late Cretaceous and the Eocene when "upper slope" and "lower slope" conditions prevailed. Regressions preceded development of the Tertlary hiatuses (fig. 49), and the site became part of the outer shelf in late Mlocene, before returning to a slope milieu in the Quaternary (Poag, this volume).

Strong acoustic reflectors on line 25 commonly are assoctated with disconformities (f1g. 49) detected in the COST No. B-3 well (Poag, this volume). Examples are the late oligocene horizon, the base of the Tertiary, the Cenomanian horizon, and the BarremianHauterivian horizon. The strong reflector near the base of the Tertiary could be caused by a sequence of deep-water transgressive linestones encountered in both the COST No. B-2 (Snholle, 1977) and the COST No. B-3 wells (Adinolpht and Jacobson, 1979, pl. 1). A strong reflector colnciding with the Hauterivian-Barremiar hiatus (fig. 49) appears to be associated with a regression and the landward shift of the carbonate-platform complex. Though structurally warped, the reflector appears to be shiraled in a discontinuous manner toward the northwest 
DEPTH

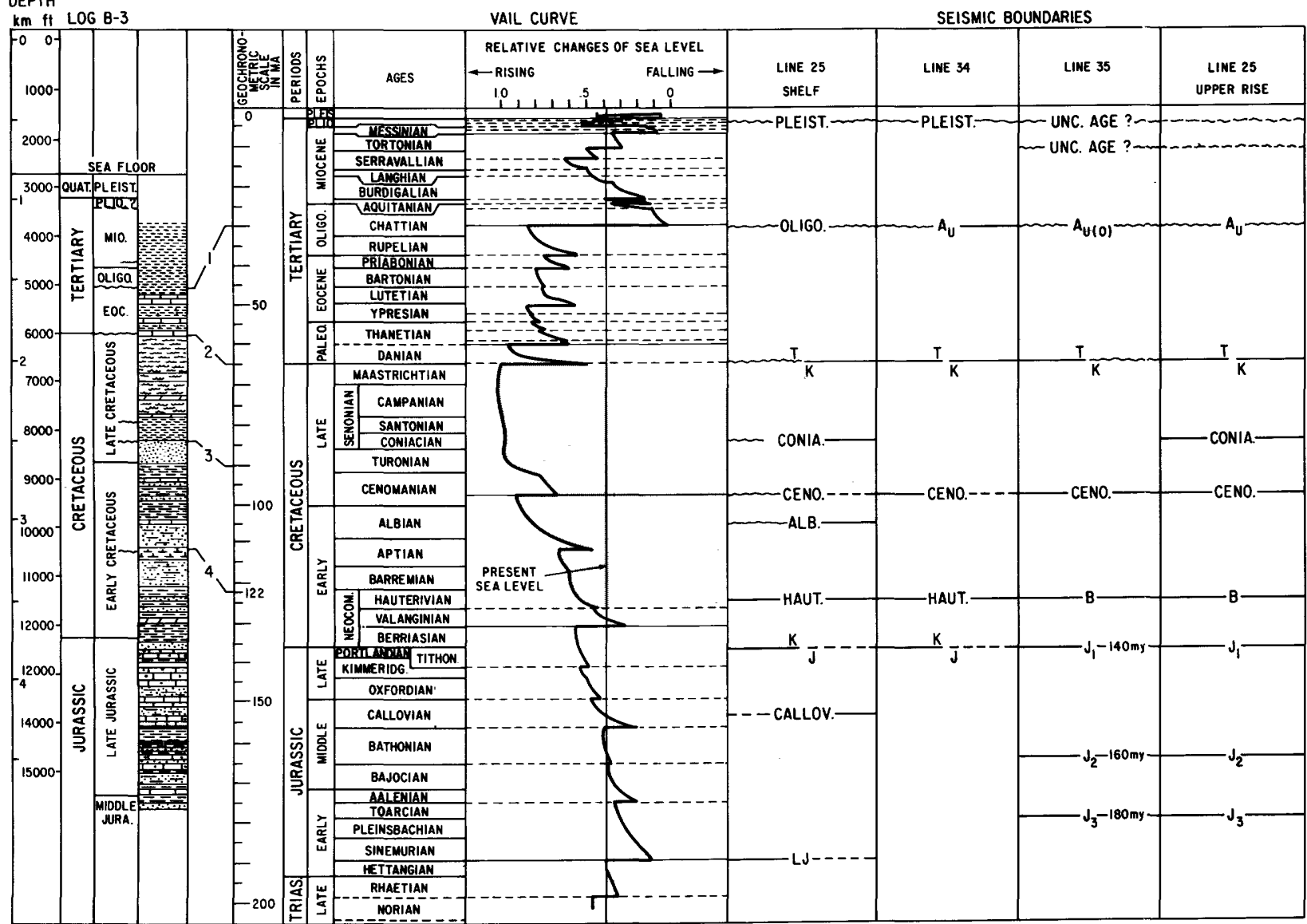

Figure 50.--A tabulation of the major reflectors distinguished on USGS Seismic Lines 25, 34, and 35; they are keyed to the relative-sea-level curve of Vail and others (1977). Also included is a generalized lithologic log of the COST No. B-3 well showing the disconformities recognized by Poag (this volume) as wavy lines. Reflector abbreviations are CALLOV (Callovian--Poag, this volume), HAUT (Hauterivian), ALB. (near base of Albian), CENO, (Cenomanian), CON. (Coniacian), OLIGo. (within the 0ligocene), PLEIST. (near the base of the Pleistocene), and UNC (unconformity).

(point Y, fig. 49); this arrangement and the presence of a limestone unit at the top of the Hauterivian in the $\operatorname{COST}$ No. $B-3$ well suggest platform retreat during this part of the Cretaceous.

In a stepwise manner, the shallowpenetration holes (AMCOR 6021, ASP 14, ASP 15, and DSDP 108) date major units (figs. 48 and 49). Light-gray, siliceous, calcareous chalks of middle Eocene age were cored in DSDP hole 108 (Shipboard Scientific Party, 1972) and in ASP hole 15 (Poag, 1978). The rocks contain radiolarians, calcareous nannoplankton, and planktic Foraminifera, all suggestive of bathyal conditions of deposition (Poag, 1978), just as indicated in the COST No. B-3 well for the Eocene sequence (Poag, this volume; Valentine, this volume). A thin sequence (30 ft, $10 \mathrm{~m}$ ) of oligocene age was encountered in the ASP 15 hole, unconformable with both the Eocene below and the Miocene above.
Most of the upper slope in this area is underlain by a shallowly buried progradational sediment wedge, as seen in seismic records. The wedge is more than $778 \mathrm{ft}(237 \mathrm{~m})$ thick in ASP 14 and is of Miocene age; Poag (197E) noted that it consists of dark-olive-gray glauconitic sand and silty clay deposited under outer shelf conditions. In ASP 15, the sequence is much thinner (148 ft; $45 \mathrm{~m})$, and a lower to middle Miocene section was recovered (Poag, this volume).

AMCOR hole $6021(7 \mathrm{mi} ; 11 \mathrm{~km}$ northeast of the profile) drilled through $1,000 \mathrm{ft}(305 \mathrm{~m})$ of dark-gray, silty clay of Pleistocene age (Hathaway and others, 1976). As can be seen from the profile (fig. 49), a thick wedge of Plelstocene sediment underlies the shelf edge, thinning in both a seaward and landward direction. In both ASP holes, a thin cover of Pleistocene sediment unconformably overlies 
USGS LINE 25 - BALTIMORE CANYON TROUGH

NW

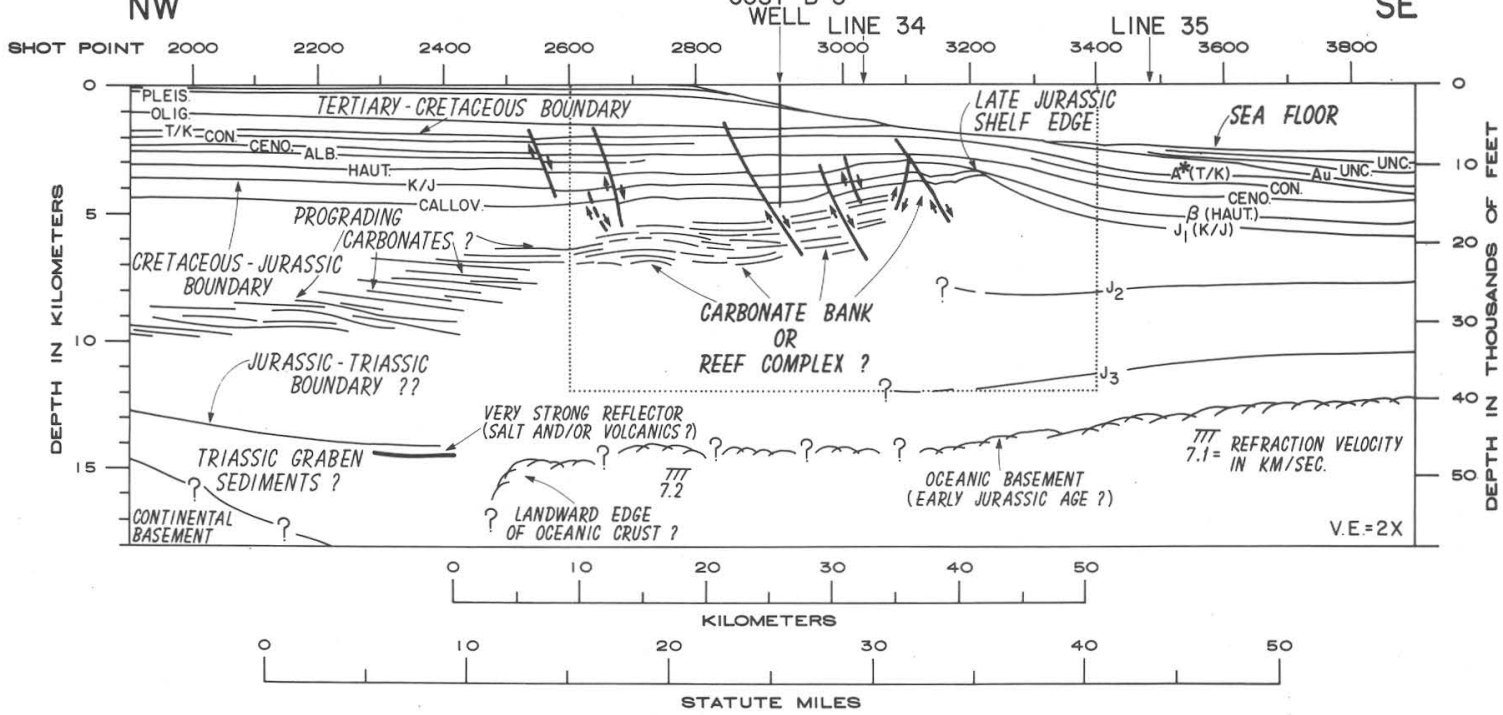

Figure 51.--An interpretation of the depth profile for USGS Selsmic Line 25 between shotpoints 1900 and 3900. Major features are the carbonate bank-reef buildup under the margin and extensions of continental and oceantc crust. Age assignments for the major reflectors are shown in figure 50. Dotted rectangle shows the area of figure 49. Approximate position of faults shown by heavy lines with arrows indicating direction of fault movement.

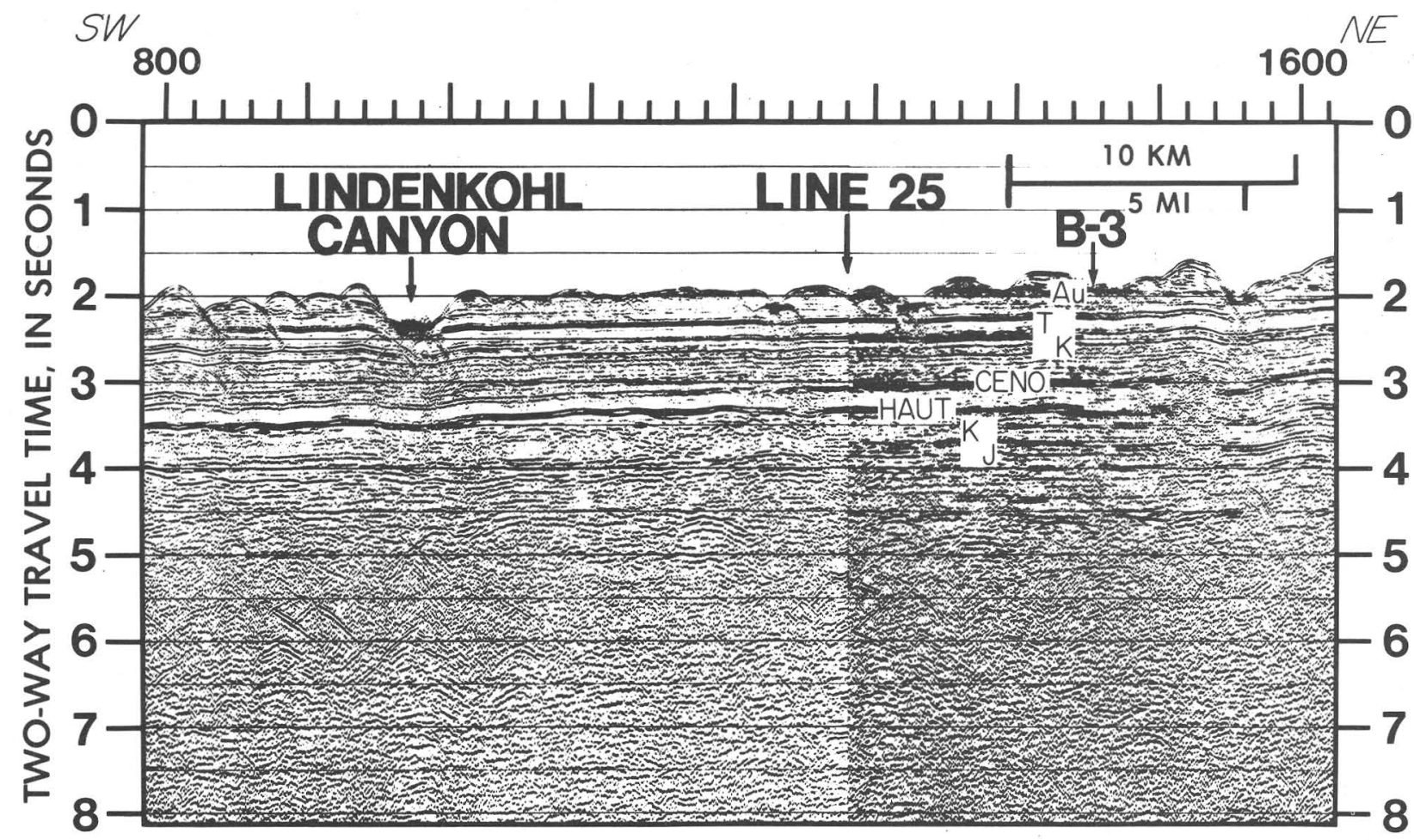

F1gure 52.--Time section of USGS Selsmic Line 34 between shotpoints 800 and 1600. reflectors are indicated on a small segment of the profile. Age designations of these reflectors are shown on figure 50. 


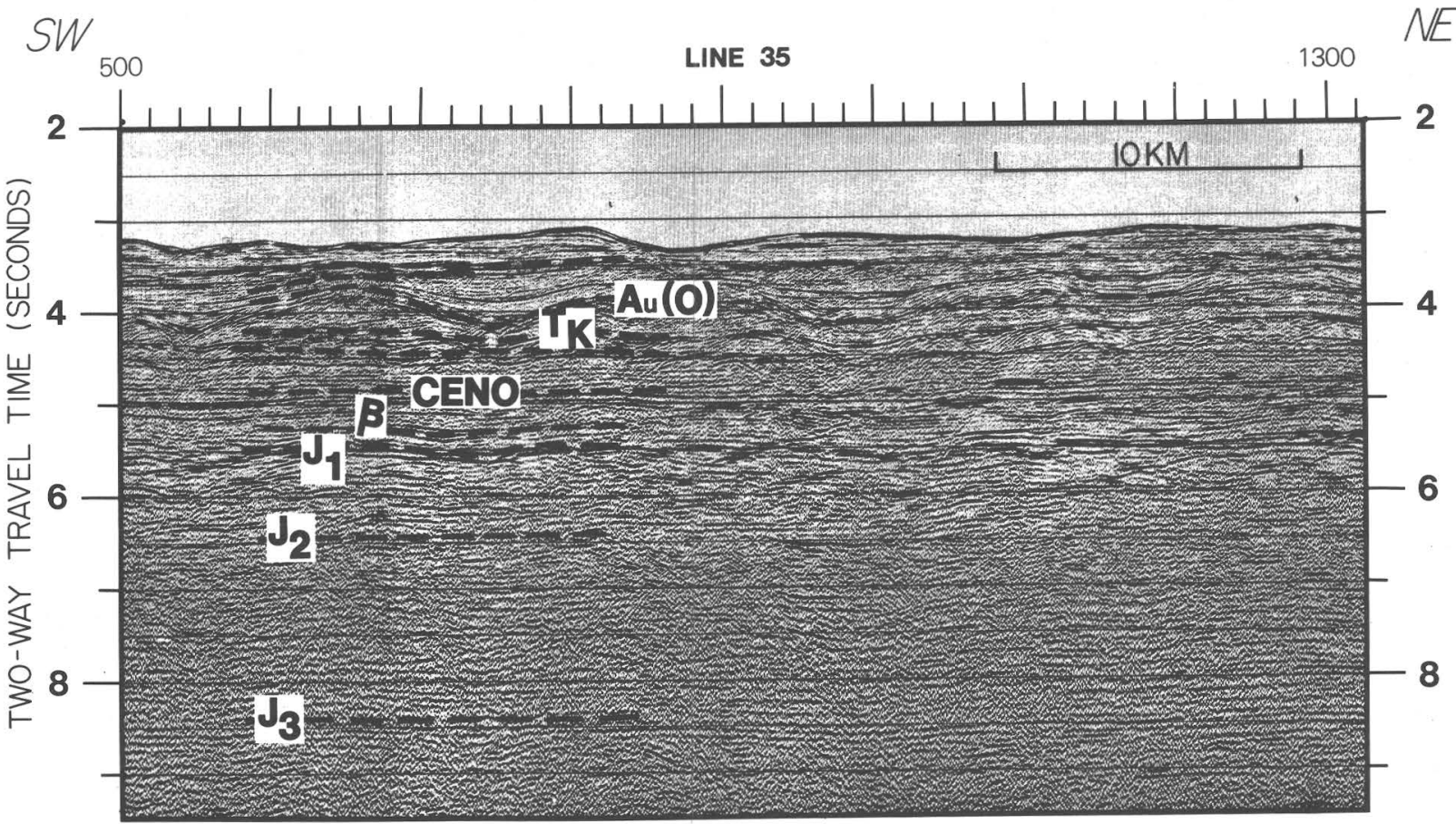

Figure 53.--Time section of USGS Selsmic Line 35 between shotpoints 500 and 1300. Major reflectors beneath the Continental Rise are indicated on a small segment of the profile. Age designations of these reflectors are shown in figure 50.

sediment of middle Miocene age (Poag, this volume); the cover is thickest (100-200 ft; 30$60 \mathrm{~m})$ in ASP 14.

\section{INTERPRETATION OF SEISMIC PROFILES}

The change in seismic character of broad groups of reflectors from the shelf to the rise (fig. 49) gives some insight into the constructional history of the margin since the Jurassic. Beneath the shelf, reflectors that were Inferred to be Jurassic and older are discontinuous and moderate to low in seismic amplitude. Utilizing the criteria of Sangree and Widmier (1977, 1979) the sequence is inferred to be a nonmarine or marginal-marine section of clastic rocks. The upper part of the section was drilled in the COST No. B-2 well and proved to be a sequence of fine- to mediumgrained sandstone, siltstone, and shale with coal seams. Under the slope, some of the reflectors of equivalent age are more continuous and higher in amplitude in the upper part of the group; to the southeast they merge with the main carbonate mass. These more continuous reflectors probably represent limestone formed in shallow-marine environments behind the platform front. Seaward of the main carbonate mass, high-amplitude, continuous and discontinuous reflectors older than Horizon (fig. 49) may be a slope facies of fore-reef breccias and pelagic limestones, as postulated by Arthur and Schlanger (1979). Still farther seaward (fig. 49), below Horizon, reflectors are discontinuous and a few high-amplitude ones are scattered among 1 ow- and moderate-amplitude reflectors. They are most likely the continuation of the slope or flank facies seen at the right of Line 25 ( $f i g$. 49).

The seaward change in acoustic character for reflectors inferred to be of Cretaceous age is less pronounced than that seen in the thick, Jurassic sequences of shale (weak amplitude) interbedded with scattered sequences of limestone (high continuity, moderate amplitude) which accumulated in a slope environment. Beneath the rise (fig. 53), where inferred Tertiary reflectors are semicontinuous and of moderate intensity, their arrangement is dominated by major hiatuses. As seen in figure 53, the seismic character of this group of reflectors probably indicates onlapping-fill and slope-front-fill facies (Sangree and Widmier, 1977, 1979) of a lower slope environment covering broad, channel-1ike erosion surfaces (Au) whose axes trend normal to the present slope. The younger groups of reflectors are part of the rise wedge built of silt and clay obtained through the periodic cutback of the slope during the Cenozoic. Proximal sources upslope and on the shelf supplied the sediment from which the wedge was constructed. 
DEEP STRUCTURE AND EVOLUTION OF

THE BALTIMORE CANYON TROUGH

IN THE VICINITY OF THE COST NO. B-3 WELL

John A. Grow

\section{INTRODUCTION}

The recent avallability of both multichannel seismic-reflection data and deep driling information from the Outer Continental Shelf off New Jersey has begun to answer many important geologic questions concerning the deep structure and evolution of the Atlantic Continental Margin since North America and Africa rifted apart in Late Triassic or Early Jurassic time. Although earlier refraction studies had detected $16,500-\mathrm{ft} / \mathrm{s}(5-\mathrm{km} / \mathrm{s})$ refractors at depths of $1.2-3.7 \mathrm{ml}(2-6 \mathrm{~km})$ beneath the Outer Continental Shelf that were inferred to be basement (Drake and others, 1959), the first multichannel lines measured as much as $7.5 \mathrm{ml}(12 \mathrm{~km})$ of sedimentary section (Mattick and others, 1974; Schlee and others, 1976) and supported interpretations of the highvelocity horizons as carbonate-bank or reef deposits of Late Jurassic and Early Cretaceous age (Emery and Uchupi, 1972; Sheridan, 1974; Sheridan and others, 1979). The COST No. B-2 well was the first deep stratigraphic we1l on the U.S. Atlantic Outer Continental Shelf (fig. $54)$; it sampled $3 \mathrm{mi}(4.8 \mathrm{~km})$ of Upper Jurassic to Pleistocene shallow-water-marine and nonmarine sediments (Smith and others, 1976; Scholle, 1977; Poag, 1979; Grow, Mattick, and Schlee, 1979). More recent multichannel depth sections across the Outer Continental Shelf and Slope (Grow, Mattick, Schlee, 1979; Schlee and others, 1979; Mattick and others, 1978) reveal that the Late Jurassic and Early Cretaceous shelf edge off New Jersey is about $12.5 \mathrm{mi} \mathrm{(20}$ $\mathrm{km}$ ) seaward of the present shelf and about $25 \mathrm{mi}$ $(40 \mathrm{~km})$ seaward of the East Coast Magnetic Anomaly (ECMA) (fig. 54).

The ECMA has been interpreted as a "magnetic edge effect" due to the oceancontinent boundary (Keen, 1969; Keen and Keen, 1974; Klitgord and Behrendt, 1979). Recent refraction data (Sheridan and others, 1979) and gravity models of the ocean-continent boundary structure (Grow, Bowin, and Hutchinson, 1979) have supported the interpretation that the ECMA

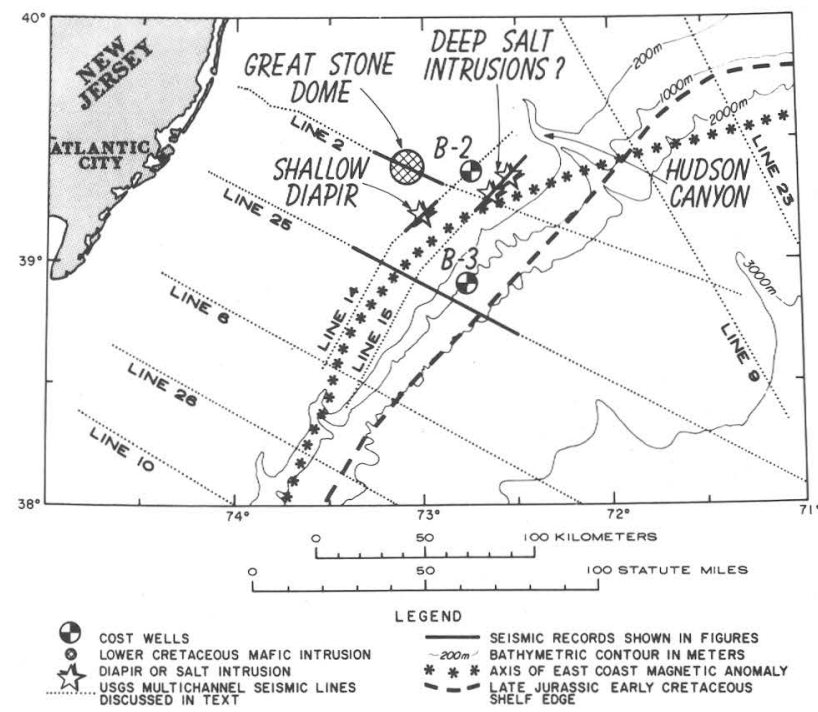

Figure 54.--Continental Margin off New Jersey showing primary structural features and seismic profiles discussed in this report. The Late JurassicEarly Cretaceous shelf edge has been mapped using elght seismic profiles and is approximately $12 \mathrm{ml}(20 \mathrm{~km})$ seaward of the present shelf edge as marked by the reglonal trend of the 650-ft $(200-\mathrm{m})$ 1sobath. The boundary between continental and oceanic crust is inferred to be marked by the East Coast Magnetic Anomaly (ECMA). The COST No. B-3 well is about $3 \mathrm{mt}(5 \mathrm{~km})$ seaward of the present shelf edge and $9 \mathrm{mi}$ (15 $\mathrm{km}$ ) landward of the Late JurassicLower Cretaceous shelf edge. Note that the shelf edge prograded $25 \mathrm{mi}$ $(40 \mathrm{~km})$ seaward of the ECMA during the Jurassic in the area south of Hudson Canyon, whereas it retreated by about $20 \mathrm{ml}(30 \mathrm{~km})$ in the region immediately to the northeast. 
marks the boundary between oceanic crust to the southeast and thin continental or transitional crust to the northwest. Multichannel seismic penetration has typically been less than $4 \mathrm{mi}$ ( 6 $\mathrm{km}$ ) over the ECMA compared with magnetic depthto-source estimates at depths of 4-5 mi (6-8 $\mathrm{km})$. These data have been interpreted as a thickening of the oceanic basement layer beneath the ECMA (Grow, Mattlck, and Schlee, 1979; Klitgord and Behrendt, 1979). This interpretation was based on selsmic data collected prior to 1978 .

During 1978, a new, high-quality, multichannel reflection profile (Line 25, fig. 54) was collected across the Baltimore Canyon trough approximately $6 \mathrm{mi}(10 \mathrm{~km})$ south of the CosT No. B-3 well (drilled after Line 25 was shot). This reveals much deeper sedimentary reflectors than any of the lines used in previous studies by the USGS. The profile was a 48-channel line collected by Geophysical Services Inc. under contract to the USGS. Advanced processing steps, including deep-water deconvolution, signature deconvolution, migration, and depth conversion, were completed during the spring of 1979. In addition to the high quality of the basic data and the opportunity for advanced processing, Line 25 is the first publicly avallable multichannel seismic line through the broadest and least complex part of the Baltimore Canyon trough. Because much deeper penetration was obtained on this line than with our previous data, this report will discuss Line 25 in some detail and will review selected portions of previous lines that bear on the deep structure and evolution of the ocean-continent boundary structure in the vicinity of the Baltimore Canyon trough and the CosT No. B-3 we11.

\section{MULTICHANNEL SEISMIC LINE 25}

Line 25 extends nearly $200 \mathrm{mi}(320 \mathrm{~km})$ southeast from Atlantic City, N.J., passing $6 \mathrm{mi}$ $(10 \mathrm{~km}$ ) south of the COST No. B-3 well (fig. 54). A summary cross section of the entire length of Line 25 is shown in figure 55; and a $53-\mathrm{ml}(85-\mathrm{km})$ segment of an annotated seismic record over the ECMA, COST No. B-3 well, and Jurassic shelf edge is given in figure 56. Line 25 started about $12.5 \mathrm{mi}(20 \mathrm{~km})$ from the coastline ( $\mathrm{fg}$. 54), where the shelf sediments are more than $3 \mathrm{mi}(5 \mathrm{~km})$ thick (fig. 55). The undeformed sedimentary wedge thickens seaward to approximately $9 \mathrm{mi}(14 \mathrm{~km})$ near the axis of the ECMA and appears to be underlain by another wedge of gent1y deformed, seaward-dipping reflectors between 9 and $11 \mathrm{mi}$ ( 14 and $18 \mathrm{~km}$ ) in depth (fig. 56, shot point 2350). Although the reflectors between 9 and $11 \mathrm{mi}$ (14 and $18 \mathrm{~km}$ ) in depth are interpreted to be Triassic graben deposits (which may include red beds, evaporites, and volcanic rocks), no definitive age or lithology can be assigned to these deep reflectors at this time. Because no previous seismic line has ever succeeded in recording reflections from deeper than about $4 \mathrm{mt}(6 \mathrm{~km})$ in depth near the axis of the ECMA (Grow, Mattick, and Schlee, 1979), the penetration achieved with Line 25 represents a significant improvement.

Line 25 also obtained strong, landwarddipping reflectors at $7.5-8 \mathrm{mi}(12-13 \mathrm{~km})$ in depth Immediately seaward of the Jurassic shelf edge (fig. 56, shot point 3400), and these are interpreted as Early Jurassic Continental Rise turbidites which originally dipped to the southeast and gradually reversed dip to the northwest during the deposition and subsidence of the Baltimore Canyon trough. Although one previous seismic line off New Jersey had detected landward-dipping reflectors at 5.5-6 mi (9-10 km) in depth seaward of the Late JurassicEarly Cretaceous shelf edge (Line 2 depth section, Grow, Mattick, and Schlee, 1979), the strong reflectors at $7.5-8 \mathrm{mi}(12-13 \mathrm{~km})$ in depth on this portion of Line 25 indicate that the depth to oceanic basement beneath the Continental Rise off New Jersey is 1-2 $\mathrm{mi} \mathrm{(2-3}$ $\mathrm{km}$ ) deeper than estimated from previous seismic lines $(25 \mathrm{mi}(40 \mathrm{~km})$ northeast and southwest of Line 25).

Although a very strong reflector at $9 \mathrm{mi}$ $(14.5 \mathrm{~km})$ in depth beneath the ECMA was detected on Line 25, its reflectivity is difficult to recognize in figure 56 because this record has time-variant scaling $(500 \mathrm{~ms})$ which suppresses strong events and amplifies weak events. The strong reflector associated with the ECMA is more dramatically shown in a true-amplitude display (fig. 57, a time section that has not been converted to depth). The amplitude anomaly at 6.5 seconds in figure 57 is equivalent to the "very strong reflector" at $9 \mathrm{mi}(14.5 \mathrm{~km})$ in depth in figure 56. The amplitude anomaly does not appear to be explainable as a multiple or any other kind of artifact produced during acquisition or processing. The types of sedimentary and (or) igneous rocks that could give such an impedance contrast at a depth of greater than $9 \mathrm{mi}(14.5 \mathrm{~km})$ remain a matter of speculation, but interbedded low impedence units (salt?) and high-impedance units (volcanic rocks, dolomites, and (or) limestones) are one possibility. This does not exclude the possibility that such salt, volcanic, and carbonate deposits could be incorporated in Triassic grabens that probably, by analogy with onshore exposures, are composed predominantly of continental red beds and arkoses (Hubert and others, 1978). Another set of impressive amplitude anomalies was observed on Line 25 at between 4 and 5 seconds in depth (fig. 57). These climb upward towards the southeast, rising from $6 \mathrm{mi}(10 \mathrm{~km})$ in depth beneath the west flank of the ECMA to about $2.5 \mathrm{mi}(4 \mathrm{~km})$ in depth in the vicinity of the Jurassic shelf edge (fig. 56). Their origin remains speculative, but a prograding carbonate sequence deposited as a bank or reef complex appears to be the most 


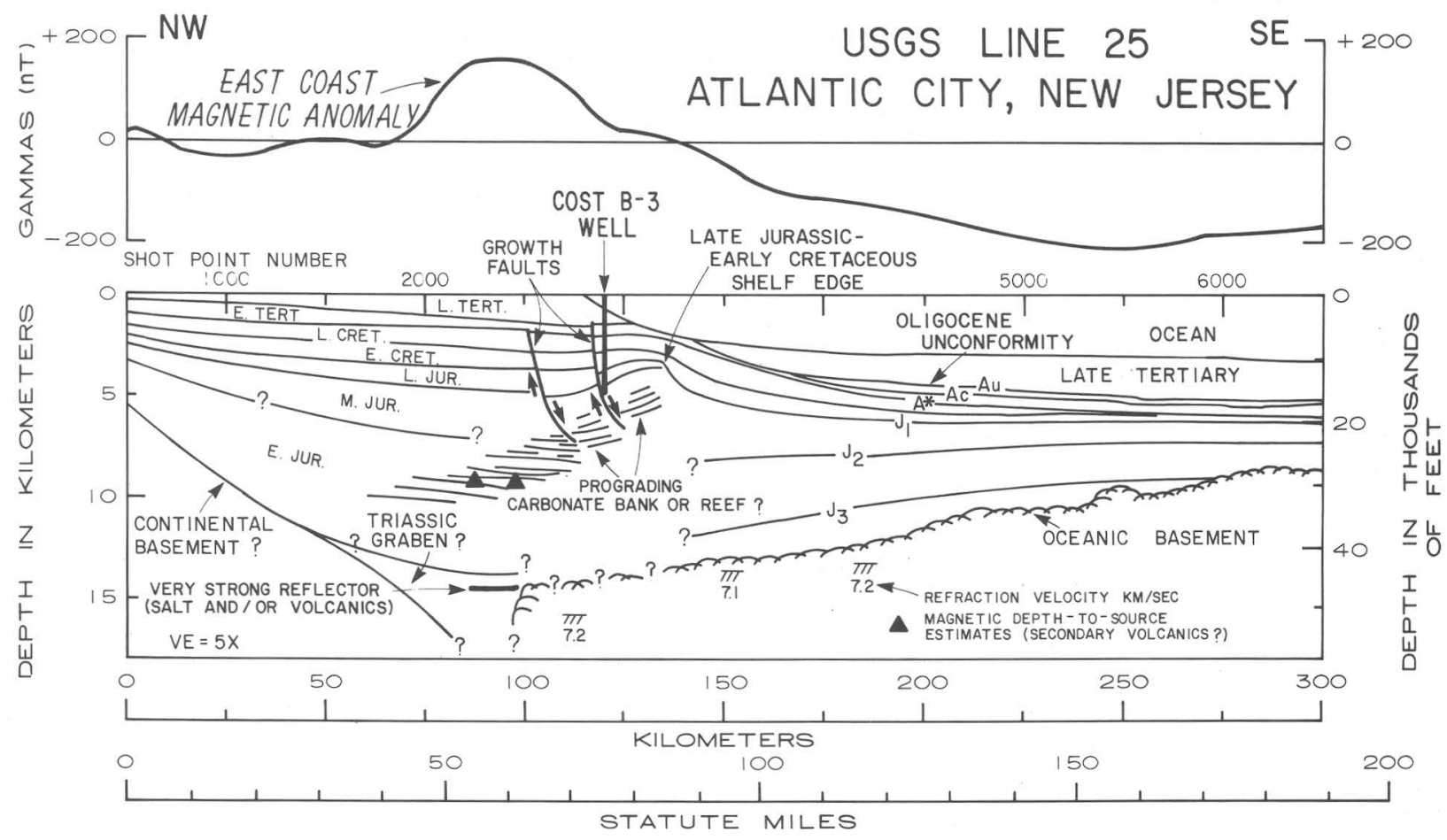

Figure 55.--Structural cross section along USGS multichannel Seismic Line 25. The actual seismic record between shot points 1900 and 3600 is shown in figure 56. Age designations for named reflectors are shown in figure 50 .

obvious possibility. The significant carbonate content in the Jurassic section of the B-3 well (Pollack, this volume) supports the inference of a prograding carbonate bank; whether it was a reef or not is uncertain. The high-amplitude reflectors may represent carbonate rocks deposited in "back-reef" environments.

A third set of amplitude anomalies observed on Line 25 dips seaward from 6.5 to 7.5 seconds (shot points 2000 to 2200, fig. 57) . These appear to form the base of the Triassic-Jurassic sedimentary wedge; that is, the top of continental basement. Individual blocks of fragmented continental crust were not observed beneath these strong seaward-dipping events in either the migrated or unmigrated data, although the resolution capability of multichannel seismic techniques at depths in excess of $8 \mathrm{mi}$ $(12 \mathrm{~km})$ is limited. Further towards land, these strong reflectors merge into what appears to be a major unconformity, which may be equivalent to Falvey's (1974) "breakup unconformity."

Another phenomenon displayed on Line 25 better than on previous seismic lines is the occurrence of seaward-dipping growth faults (that is, listric normal faults) between the ECMA and the Jurassic shelf edge (fig. 56). The downward continuation of these growth faults is obscured by the prograding carbonates, but they probably go considerably deeper than shown and may ultimately tie into bedding-plane faults along the Jurassic slope. The faults were probably most active during the time of Jurassic carbonate-platform progradation, but movement appears to have continued on a few of these faults through the Late Cretaceous. The fault immediately landward of the COST No. B-3 we11 appears to have offset early Tertiary horizons by several tens of feet, but does not appear to displace late Tertiary sediments on Line 25.

Klitgord and Behrendt (1979), in a magnetic depth-to-source study of the ECMA, observed a systematic pattern of low- or intermediatestrength solutions at 4-5 $\mathrm{mf}(6-8 \mathrm{~km})$ in depth near the axis of the ECMA compared to solutions at $6-7.5 \mathrm{mi}(10-12 \mathrm{~km})$ in depth on either side. Similar magnetic depth-to-source results were found near Line 25, and they are shown as triangles in figure 56 (K. Klitgord, oral communication, 1979). They occur at about 5.6 mi $(9 \mathrm{~km})$ in depth, just beneath the reflectors interpreted as prograding carbonates and more than $3 \mathrm{mi}(5 \mathrm{~km})$ above the strong reflector at 9 $\mathrm{mi}(14.5 \mathrm{~km}$ ) ( $\mathrm{fig} \cdot 56)$. Although none of our previous selsmic lines obtained selsmic penetration deeper than $4 \mathrm{mi}(6 \mathrm{~km})$ near the ECMA, Line 25 clearly suggests that the magnetic solutions are well up in the sedimentary section. Therefore, interpretations of the ECMA involving a thickened ridge of oceanic basement underlying the anomaly (Grow, Mattick, and Schlee, 1979; K1itgord and Behrendt, 1979) must now be revised. While the ECMA probably still marks the landward edge of oceanic crust, the 


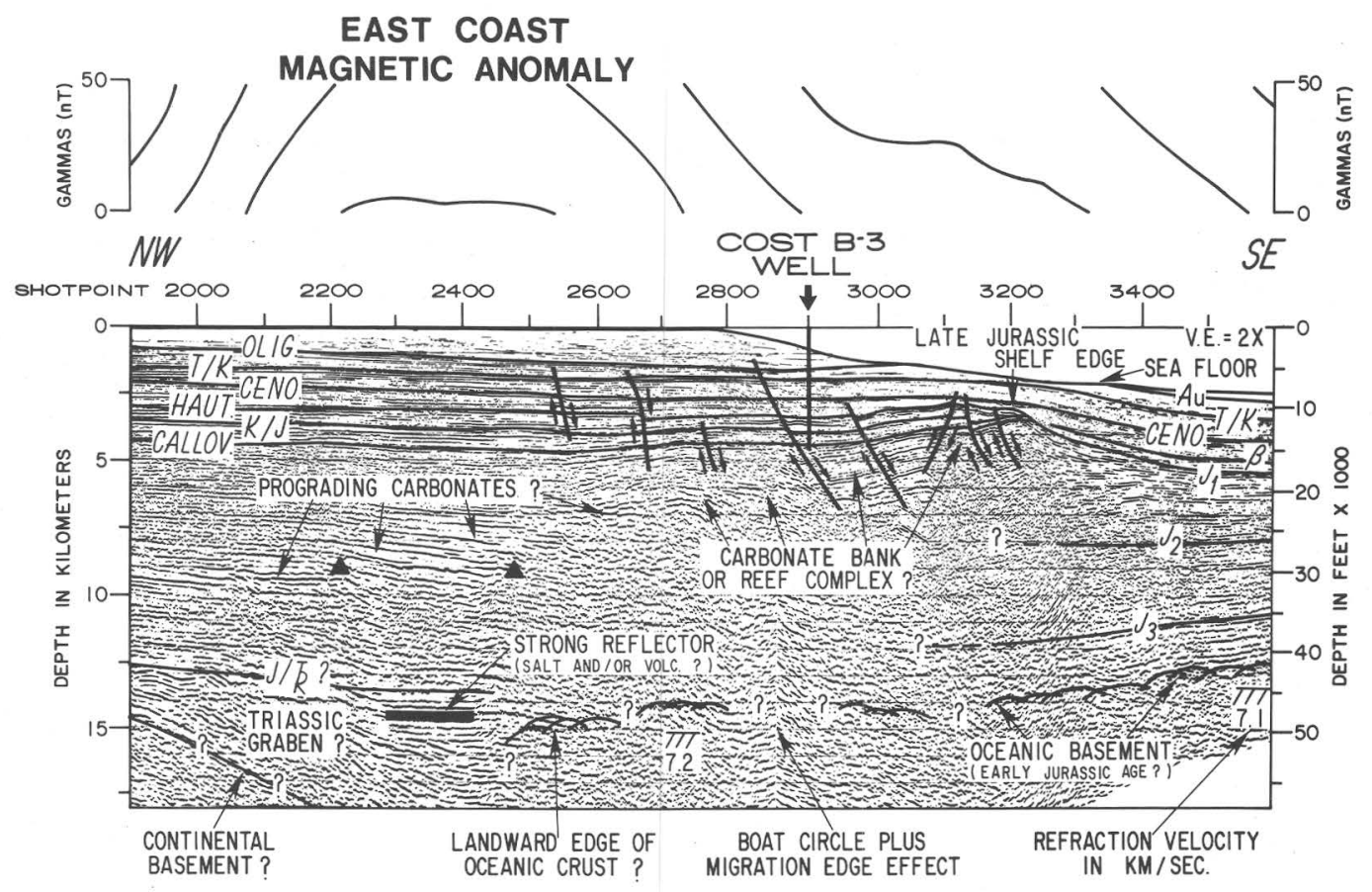

$\underset{10 \text { KILOMETERS }}{10 \text { STATUTE MILES }} \quad \Delta=$ MAGNETIC DEPTH SOLUTIONS

Figure 56.--Annotated multichannel depth section (migrated) for USGS Seismic Line 25 with magnetic anomalies plotted at the top. Line 25 is the first selsmic profile to achieve penetration deeper than about $4 \mathrm{mi}(6 \mathrm{~km})$ in the vicinity of the ECMA and the first profile to record reflected energy from deeper than 5-6 $\mathrm{mi}(9-10 \mathrm{~km})$ in the region immediately seaward of the Late Jurassic-Early Cretaceous shelf edge. Age horizons on shelf from Amato and Simonis (1979), Poag (this volume), and Valentine (this volume). Deep-sea correlations from Klitgord and Grow (In press). The triangles at 5 $\mathrm{mi}(9 \mathrm{~km})$ in depth beneath the ECMA are magnetic depth-to-source solutions (K. Klitgord, oral communication, 1979); see text for further discussion. Location shown in figure 54; age designations for named reflectors are shown in figure 50 .

shallow magnetic solutions will have to be attributed to secondary volcanic events such as dikes, sills, and flows which could have occurred in Late Jurassic or Early Cretaceous time. Alternatively, the Werner deconvolution method for estimating magnetic depth to basement may encounter special problems at depths greater than 4-5 $\mathrm{mi}(7-8 \mathrm{~km})$, which makes these deeper solutions less reliable than those at shallower depths.

In summary, Line 25 represents an important breakthrough in our understanding of the deep structure of the Baltimore' Canyon trough and the evolution of the ocean-continent boundary structure, because it now seems probable that no basement ridge lies between 4 and $9 \mathrm{mi}$ ( 6 and 14 $\mathrm{km}$ ) in depth along the ECMA or shallower than 8 $\mathrm{mi} .(13 \mathrm{~km})$ immediately seaward of the Jurassic shelf edge. Furthermore, considering the way the deep sedimentary reflectors project seaward from beneath the shelf and landward from beneath the rise, it seems unlikely that oceanic basement is shallower than $8-9 \mathrm{mi}$ (13-14 km) beneath the COST No. B-3 well or any part of the margin between the ECMA and the Jurassic shelf edge (f1g. 56). The past fallure of multichannel seismic systems to record reflections from deeper than $4 \mathrm{mi}(6 \mathrm{~km})$ between the ECMA and the Jurassic shelf edge may be due to a combination of high-impedance reflectors in the prograding carbonate rocks, which are very difficult to penetrate, and diffraction effects caused by numerous growth faults.

\section{GREAT STONE DOME}

A mafic plutonic body, referred to as the Great Stone Dome, intruded the Baltimore Canyon trough during the Early Cretaceous (Schlee and others, 1976) and is shown in figure 58. This plutonic body appears to have been intruded 3040 million years after the separation of North America and Africa, and its emplacement created a local unconformity of approximately Aptian age. No other mafic intrusions are known to intrude the Late Jurassic and younger basins 


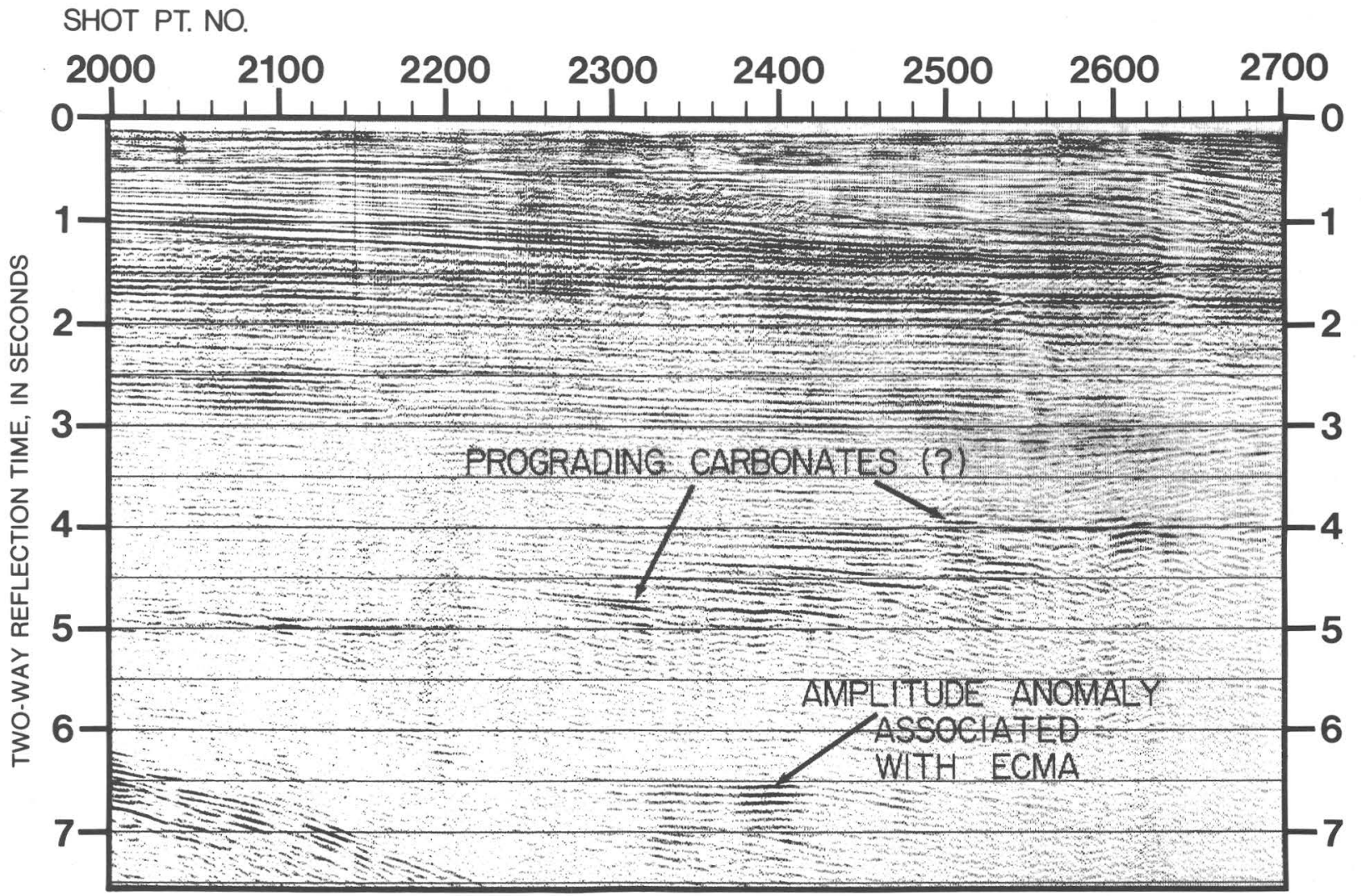

Figure 57.--True-amplitude display (time section) of USGS Seismic Line 25 showing three deep amplitude anomalies. See figure 56 for comparison with depth section that has timevarlant scaling (that 1s, weak reflections are amplified while strong reflections are reduced). ECMA is the East Coast Magnetic Anomaly.

beneath the Continental Shelf off the Eastern United States, although Cretaceous volcanism has been found along the New England seamounts and In the White Mountains of Vermont (Tucholke and others, 1979). The possibility of secondary volcanism occurring $30-40$ million years after separation of Africa and North America and the formation of the ocean-continent boundary which is inferred to be the source of the ECMA may help explain the apparent conflict between shallow magnetic-depth-to-basement values at 4-5 mi (6-8 km) in depth along the ECMA (K1itgord and Behrendt, 1979) and the deeper sediment penetration obtained on multichannel Line 25. For example, small quantities of secondary volcanic rocks such as dikes and sills may have also leaked up from the ocean-continent boundary zone periodically during the Jurassic and (or) Early Cretaceous, which now give rise to the magnetic depth-to-source estimates at 4-5 $\mathrm{ml}$ (6$8 \mathrm{~km}$ ) depth.

\section{POSSIBLE SALT STRUCTURES IN BALTIMORE CANYON TROUGH}

Extensive salt diapirs and related structures have been found along the Continental
Shelf and Slope off eastern Canada (Emery and Uchupi, 1972; Jansa and Wade, 1975; Uchupi and Austin, 1979), but have only recently been reported off the Eastern United States. A linear chain of diapir structures has been found along the ECMA off Cape Hatteras which is thought to be salt (Grow and Mark1, 1977; Grow and others, 1977), and at least three probable salt structures occur along the ECMA where it swings landward of the shelf edge in the Baltimore Canyon trough region (fig. 54).

A diapir structure that penetrates up into Tertiary sediments has been observed on Line 14 (fig. 59), and two probable salt intrusions were also seen on Line 15 ( $f$ Ig, 60). The latter intrusions do not penetrate Cretaceous and Tertiary sediments, probably because they. were blocked from shallower penetration by mechanically strong carbonate rocks in the prograded carbonate bank or reef complex. Salt has also been encountered at a depth of $2.4 \mathrm{ml}$ $(3.8 \mathrm{~km})$ in an exploration well on the south flank of the Great Stone Dome (011 and Gas Journal, 1978), which may be due to salt diapirism in that area having been triggered by the more dominant mafic pluton. 


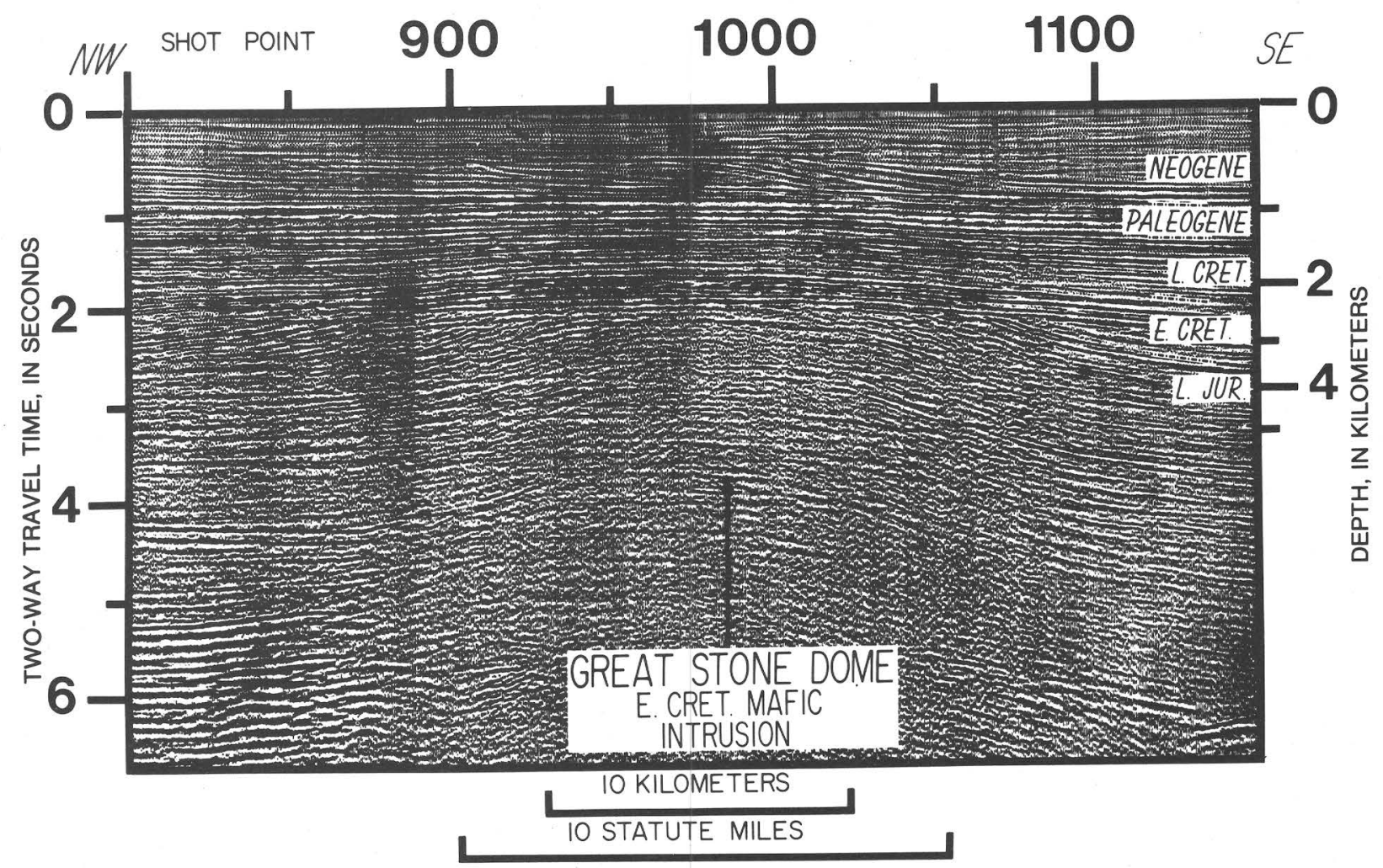

Figure 58.--Multichannel seismic section (Line 2) over the Great Stone Dome. To date, exploration wells have not yielded significant indications of oil or gas on or near this dome (modified from Schlee and others, 1976). Location shown in figure 54.

The salt off eastern Canada is found in the Early Jurassic Argo Formation (Jansa and Wade, 1975); and a similar age can be expected for the salt off the Eastern United States. The origin of salt along the margins of the Atlantic Ocean remains a matter for debate, but the most 11 kely explanation is that evaporite basins formed along the continental shelves in a shallow seaway during the initial separation of Africa and North America, probably as a consequence of restricted oceanic circulation (Evans, 1977).

One other possible diapir has been proposed in the Baltimore Canyon trough, just north of Wilmington Canyon and also along the ECMA (Sheridan, 1975), but subsequent multichannel

Figure 59.--Multichannel selsmic section (Line D 14) over inferred salt diapir which appears to have orfinated from very deep in the Jurassic section and penetrated into Tertiary sediments. No exploration wells have sampled this structure to date. Location shown in figure 54.

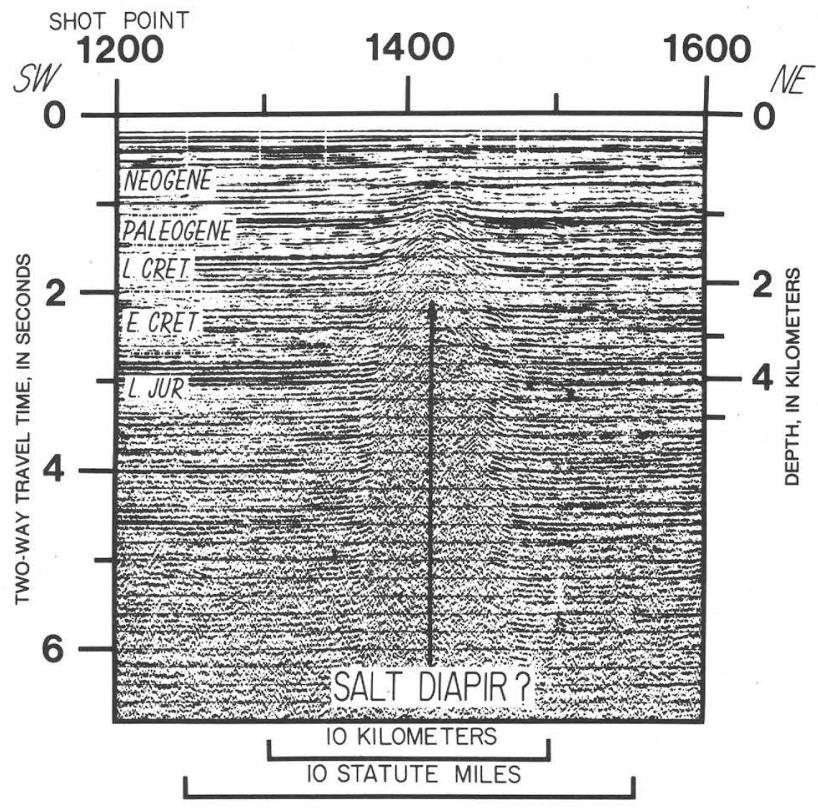




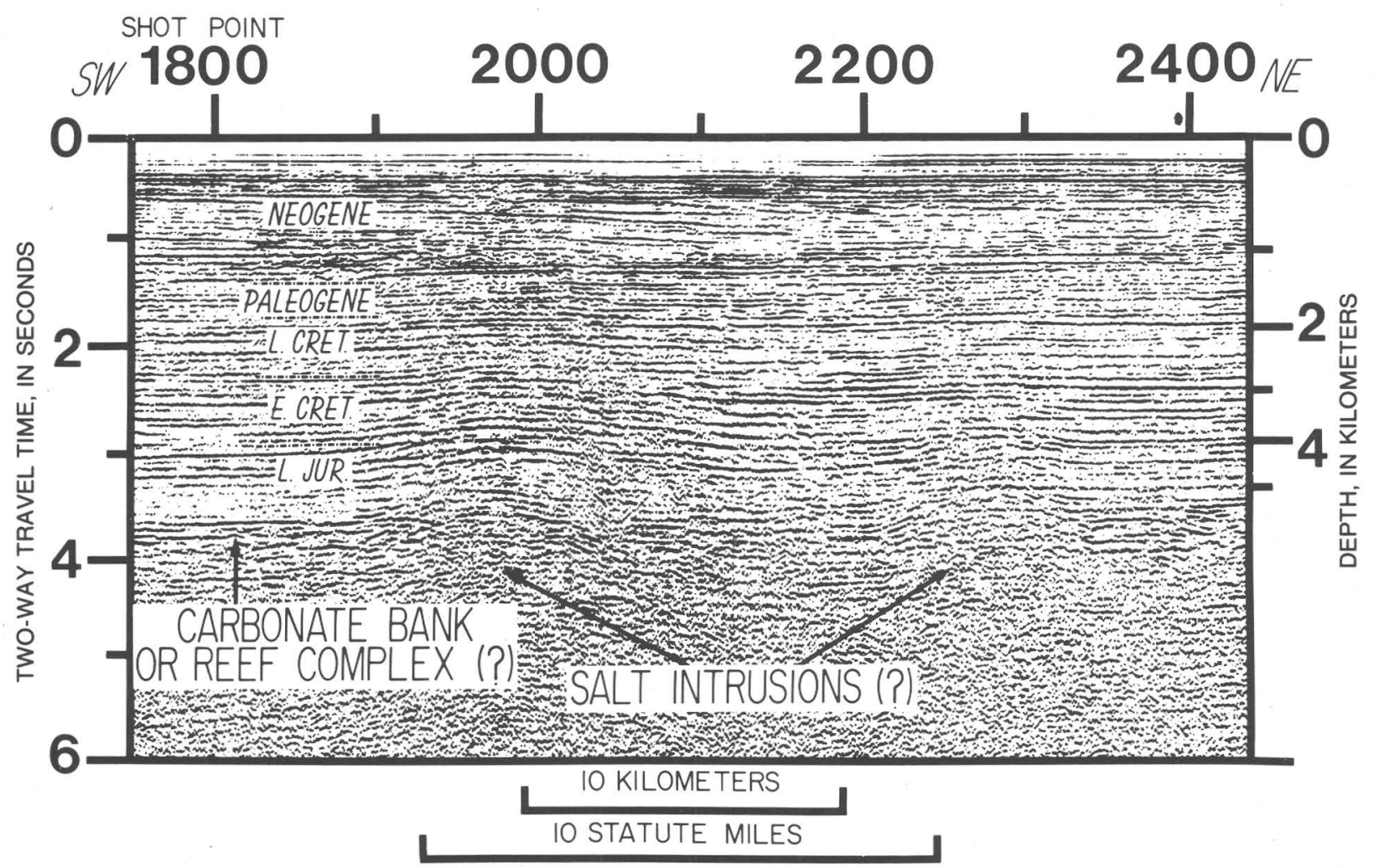

Figure 60.--Multichannel seismic section (Line 15) showing two small, deep domes which are inferred to be salt intrusion. Natural gas has been discovered in three exploration wells drilled by Texaco and Tenneco on the northeastern intrusion, but drilling on the southwestern structure by Exxon has not indicated any significant shows of either oil or gas. Location shown in figure 54.

seismic profiles within $1.2 \mathrm{mi}(2 \mathrm{~km})$ of this proposed structure (Line 6 and the southern part of Line 14) have not detected any obvious salt intrusion in that area. Although additional salt intrusions will probably be detected as more multichannel seismic lines become available, the quantity of salt at depth in the Baltimore Canyon trough is small in comparison to the quantity off Canada or even in comparison to the zone south of Cape Hatteras. Nevertheless, these probable salt structures do suggest a similar structural history to that of Canada, even if the quantity of salt deposited in such Early Jurassic seaways was variable.

\section{DEEP STRUCTURE AND EVOLUTION}

A schematic cross section through the Baltimore Canyon trough near the COST No. B-3 well depicts the overall crustal and sedimentary structure in this part of the trough (fig. 61).

Because the B-3 well bottomed in sediments of Middle(?) Jurassic age at $3 \mathrm{mi}(4.8 \mathrm{~km})$ in depth, the remaining $8 \mathrm{mi}(13 \mathrm{~km})$ of stratified sediments seen on Line 25 are probably Triassic through Middle Jurassic in age. In the main part of the basin, near and just west of the ECMA, the sediments are undeformed down to about
$9 \mathrm{mi}(14 \mathrm{~km})$ in depth, except for variable tilt related to differential regional subsidence. The stratified section between 9 and $11 \mathrm{mi}$ (14 and $18 \mathrm{~km}$ ) in depth near the ECMA (fig. 56) shows gentle deformation, probably caused by deposition in a rapidly subsiding graben underlain by small crustal blocks subsiding independently.

The gravity and refraction data (fig. 61) support the interpretation that the oceanic crust continues westward to the ECMA and that the ECMA is caused by a magnetic edge effect between thin continental or transitional crust to the west and oceanic crust to the east (Keen, 1969; Keen and Keen, 1974; Klitgord and Behrendt, 1979; Grow, Mattick, and Schlee, 1979; Sheridan and others, 1979; Grow, Bowin, and Hutchinson, 1979). The oldest oceanic crust is probably Early Jurassic in age (K1itgord and Behrendt, 1979). This is consistent with the inception of volcanism in the Newark and Connecticut grabens at the Triassic-Jurassic boundary (Cornet, 1977; Hubert and others, 1978).

Recent geophysical studies of continental rifting in the Bay of Biscay, along with new deep-sea-drilling results, indicate that the 


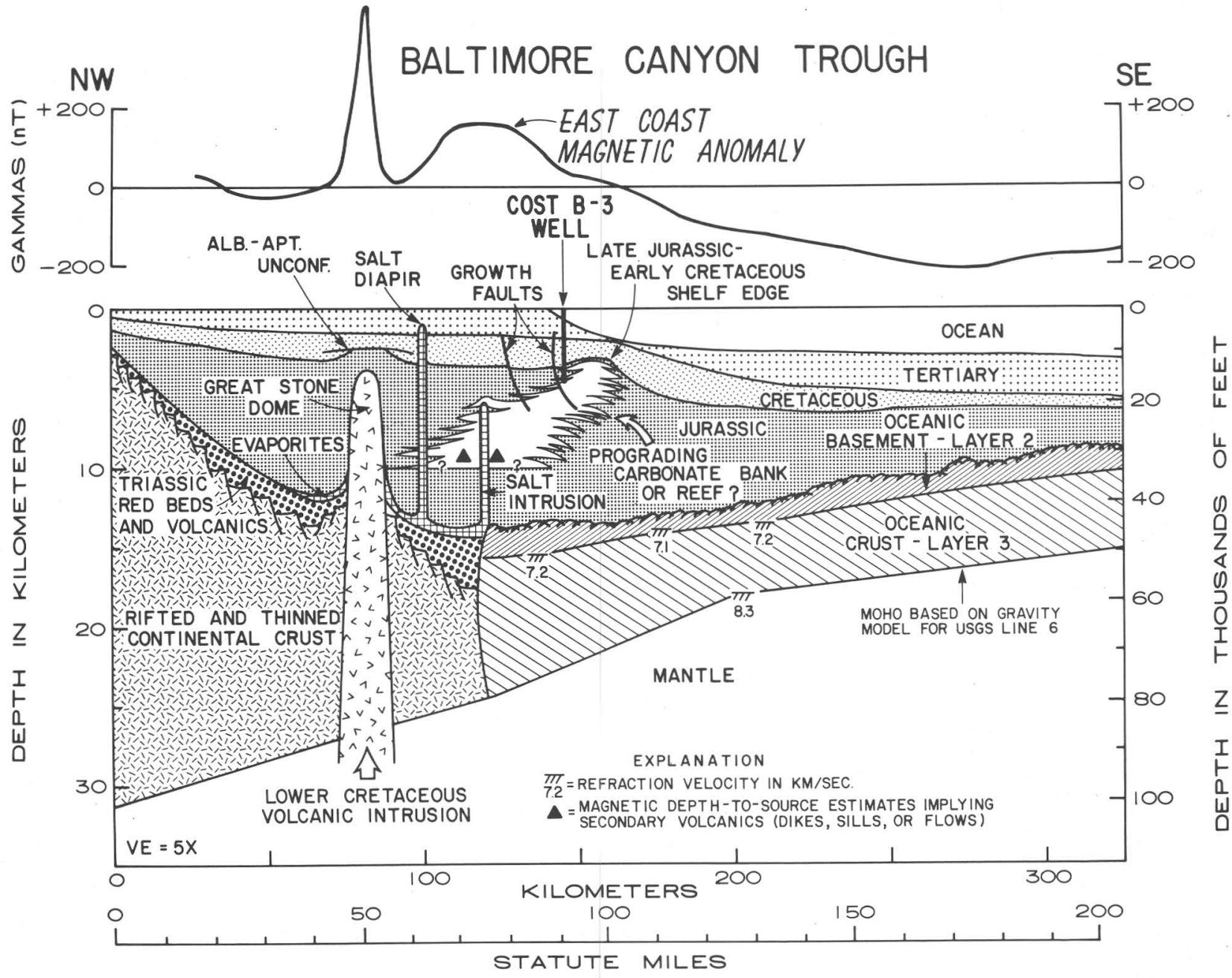

Figure 61.--Schematic cross section through Baltimore Canyon trough approximately along Seismic Line 25 (figs. 55 and 56) with nearby COST No. B-3 we11, geologic features, and geophysical parameters projected into the profile. Refraction data are from Ewing and Ewing (1959) and Sheridan and others (1979). The moho configuration is projected from a gravity model for Line 6 .

transition from deformed graben sediments, referred to as syn-rift sediments, to undeformed basin sediments, referred to as post-rift sediments, occurs after the continental crust has been thinned and at the inception of seafloor spreading (Montedert and others, 1979). The Bay of Biscay model suggests that syn-rift sediments are deposited while the continental crust is being thinned by necking in the lower crust and listric normal faulting in the brittle upper crust. The unconformity marking the transition from syn-rift to post-rift sediments can be considered equivalent to the "breakup unconformity" of Falvey (1974).

Applying the Bay of Blscay model (Montadert and others, 1979) to the Baltimore Canyon trough and assuming that the transition from continental rifting to sea-floor spreading began at the Triassic-Jurassic boundary, we may infer that all of the undeformed sediments between 3 and $9 \mathrm{mi}$ ( 5 and $14 \mathrm{~km}$ ) in depth near the ECMA on Line 25 are Early and Middle Jurassic in age (figs. 56 and 61). It follows from this model that the deformed sediments between 9 and $11 \mathrm{mi}$ (14 and $18 \mathrm{~km}$ ) near the ECMA (ffg. 56) are Triassic in age (fig. 61). The graben sediments probably contain predominantly continental red beds but might include some volcanics and evaporites, especially near the base of the Early Jurassic (fig. 61).

Following thinning of the continental crust during the Triassic, along with related deposition within Triassic syn-rift grabens, and the initiation of sea-floor spreading during the earliest Jurassic, the shelf edge prograded about $25 \mathrm{mi}(40 \mathrm{~km}$ ) east of the ECMA during the Early and Middle Jurassic. The cause of this 
progradation is not known, but carbonate bankand (or) reef-bullding processes may have been important. The Jurassic section within the COST No. B-3 well contained a substantial thickness of carbonate rocks, but, because this well is about $9 \mathrm{mi}(15 \mathrm{~km})$ landward of the Late Jurassic shelf edge (fig. 56), further drilling is needed before the carbonate-bank and (or) reef model can be substantlated. Note that north of Hudson Canyon (fig. 54), the Jurassic shelf edge lies 12-19 $\mathrm{mi}(20-30 \mathrm{~km})$ landward of the ECMA, thereby suggesting that the shelf edge retreated during the Jurassic in that area. The Late Jurassic-Early Cretaceous shelf edge off Cape Hatteras and Cape Cod also indicates either retreat or nonprogradation during the Jurassic in those areas (Grow, Mattick, and Schlee, 1979; Schlee, Dillon, and Grow, 1979).

Great Stone Dome is an isolated igneous intrusion that intruded during the Early Cretaceous; it is unique along the eastern margin of North America. No evidence is available at this time to determine whether it was derived from the mantle or from within the crust. The strong magnetic anomaly over the dome suggests a mafic intrusive which would probably have been generated in the mantle. However, its intrusion followed very rapid subsidence during the Jurassic $(6 \mathrm{mi}(10 \mathrm{~km})$ of Jurassic sediments versus approximately $1.2 \mathrm{mi}$ (2 km) each during the Cretaceous and Tertiary), which might have pushed radiogenic upper continental crust and graben sediments deep enough to initiate igneous melting. Samples from exploration wells on the Great Stone Dome have not been released to date, but petrologic analyses may yet become available to shed light on this question.

The intrusion of the salt structures along the ocean-continent boundary in the Baltimore Canyon trough area appears to have occurred during the Late Jurassic and Early Cretaceous for the two structures on Line 15 ( $\mathrm{f} 1 \mathrm{~g} .-60)$ and during the Tertfary for the shallow diapir on Line 14 (fig. 59).

The final major event in the evolution of the Baltimore Canyon trough has been the retreat of the shelf edge during the Late Tertiary (Grow, Mattick, and Schlee, 1979; Schlee, Dillon and Grow, 1979; Schlee and Grow, this volume). The 12.5-mi $(20-\mathrm{km})$ retreat of the shelf edge appears to have started with a massive submarine erosional event during the late oligocene and is probably related to frequent regressions of sea level since that time (Vail and others, 1977; Poag, this volume).

\section{SUMMARY}

The Baltimore Canyon trough began to form during the Triassic Period when tensional stresses between North America and Africa resulted in thinning of the continental crust and deposition of sediments within rift grabens. The transition from continental rifting to sea-floor spreading probably occurred during the earliest Jurassic and was marked by volcanism and formation of evaporites due to restricted oceanic circulation. Within the portion of the Baltimore Canyon trough near the COST No. B-3 well, the shelf edge prograded 25 mi (40 km) seaward out over the initial oceancontinent boundary (ECMA) during Early and Middle Jurassic time.

The Jurassic shelf-edge progradation with respect to the ECMA occurred southwest of Hudson Canyon, while retreat occurred to the northeast (fig. 54). Because erosion and retreat of the shelf edge are also dominant north of Cape Cod and south of Cape Hatteras (Grow, Mattick, and Schlee, 1979; Schlee, Dillon, and Grow, 1979), the evidence for a Jurassic progradational event off New Jersey appears to be unfque elong the U.S. margin. On the other hand, submarine erosion removed much of the Late Jurassic-Early Cretaceous shelf-edge complex in the other areas, especially since the late 0ligocene.

The strong reflectors that occur w:thin the prograding Jurassic shelf edge suggest that a carbonate-bank and (or) reef complex underlies the outer shelf and Continental slope off New Jersey (figs. 56 and 57). The crest of this inferred Late Jurassic and Early Cretaceous carbonate complex lies $9 \mathrm{mi}(15 \mathrm{~km})$ seaward of the $\operatorname{cosT}$ No. B-3 well. Although some Jurassic carbonate rocks were encountered in the B-3 we11, the selsmic data from Line 25 suggest that more massive carbonates occur at depth beneath the B-3 well and farther southeast torard the Late Jurassic shelf edge. Only mcre deep drilling can substantiate this inference and determine if actual reefal faunas occur within the inferred carbonate complex.

\section{CONCLUSIONS}

1. The COST No. B-3 well was drilled in 2,686 ft $(819 \mathrm{~m})$ of water and penetrated 13,092 $\mathrm{ft}(3,990 \mathrm{~m})$ of sedimentary rocks in the slope area of the Baltimore Canyon trough. The age of sedimentary units was determined through the examination of Foraminifera, calcareous nannofossils, and palynomorphs. The section is Cenozolc down to about $6,000 \mathrm{ft}(1,830 \mathrm{~m})$. From 6,000 to about $9,000 \mathrm{ft}(1,830-2,750 \mathrm{~m})$, the sediments are Late Cretacoous in age. The base of the Early Cretaceous Interval is placed between 12,250 and 13,450 ft $(3,730$ and $5,000 \mathrm{~m})$ by various workers. The oldest unit in the well was considered to be Middle Jurassic (Callovian) by one worker ard Late Jurassic (Kimmeridgian) by others.

2. The sediments down to about $8,200 \mathrm{ft}(2,500$ m) are predominantly mudstones, calcareous mudstones, and micritic limestonos. In the interval from about 8,200 to $12,300 \mathrm{ft}$ $(2,500$ to $3,750 \mathrm{~m})$, medium- to coarse- 
grained sandstones, gray-brown shales, micritic limestones, and subordinate coal and dolomite are the major lithologies. Below $12,300 \mathrm{ft}(3,750 \mathrm{~m})$, to the bottom of the well at $15,820 \mathrm{ft}(4,822 \mathrm{~m})$, the section consists of limestones, fine- to medium-grained sandstones, dark-colored shales, and coal seams.

3. The Tertiary sediments were deposited, for the most part, in slope water depths. The Cretaceous section and the upper half of the Jurassic interval were deposited in lower- to outer-shelf water depth. The lower half of the Jurassic section reflects inner shelf to marginal-marine conditions.

4. Porosities of units down to about $8,200 \mathrm{ft}$ $(2,500 \mathrm{~m})$ range from 20 to 32 percent. The corresponding permeabilities of these fine-grained rocks are generally low. The interval between 8,200 and $11,630 \mathrm{ft}$ $(2,500$ and $3,550 \mathrm{~m})$ contains more than $1,000 \mathrm{ft}$ of sandstone with porosities between 16 and 24 percent. Thin sandstone and limestone untts in the interval from 11,630 to 15,820 ft $(3,550$ to $4,822 \mathrm{~m})$ have porosities between 2 and 25 percent. In general, only a moderate loss of porosity occurs with increasing burial depth in this we11, and potential reservoir units are present in most parts of the B-3 section.

5. Petrographic analysis has shown that calcite cementation is the major cause of porosity loss in this well. Feldspar decomposition and compaction have only minor influence on porosity. Most sandstones in this well are subarkoses with subordinate arkoses, quartzarenites, and feldspathic 1itharenites.

6. Temperature logs were not run in this well, but temperature data from other geophysical logs indicate an approximate geothermal gradient of $1.26^{\circ} \mathrm{F} / 100 \mathrm{ft}$ $\left(22.8^{\circ} \mathrm{C} / \mathrm{km}\right)$.

7. Organic geochemical studies, coupled with data on vitrinite reflectance and color alteration of visible organic matter, indicate that rocks down to approximately $14,300 \mathrm{ft}(4,359 \mathrm{~m})$ are thermally immature to marginally mature with respect to hydrocarbon generation. Although certain intervals above 14,300 ft $(4,359 \mathrm{~m})$, particularly in the Tertiary section above 6,000 ft $(1,830 \mathrm{~m})$, contain abundant organic matter (of both oil-prone and gasprone types), the low degree of thermal maturation makes it unlikely that these sediments have generated significant quantities of hydrocarbons. The section below $14,300 \mathrm{ft}(4,359 \mathrm{~m})$, especially in the interval from about 15,000 ft $(4,572$ m) to the base of the we11, is both thermally mature and rich in organic carbon. The section contains dominantly exinite and vitrinite types of organic matter and must therefore be considered to be gas-prone rather than of1-rrone.

8. The combination of the above-listed factors indicates that the intervals rith the best potential for hydrocarbon discoveries are in the basal part of the we11, below approximately 14,000 ft $(4,267 \mathrm{~m})$. This interval contains thermally mature source rocks, porous (and sufficiently permeable) sandstone, possibly also limestone reservoirs, and shale seals. The this interval is most likely to be gasproductive rather than oil-productive owing to the dominance of terrestrially derived organic matter. This conclusion is reinforced by the "significant" gas show encountered during drijling in the interval from 15,744 to $15,752 \mathrm{ft}(4,799$ to $4,801 \mathrm{~m})$. Some potential for both oil and gas production also exists in the marginally mature zone abovs $14,000 \mathrm{ft}$ $(4,267 \mathrm{~m})$, either through in situ generation or upward migration of hydrocarbons into reservoir units.

\section{REFERENCES CITED}

Abbott, W. H., in press, Analysf.s of diatom assemblages and stratigraphically significant silicoflagellater from the United States Geological Survey Atlantic Margin Coring Program and other Atlantic margin sites: Micropaleontolozy.

Adinolf1, Frederick, and Jacobson, S. S., 1979, Geologic correlation with othar weils, in Amato, R. V., and Simonis, E. K., eds., Geologic and operational summery, COST No. B-3 we11, Baltimore Canyon Trough area, Mid-Atlantic OCS: U.S. Geolcgical Survey Open-File Report 79-1159, p. 32-39.

Amato, R. V., and Simonis, E. K., eds., 1979, Geologic and operational summary, COST No. B-3 we11, Baltimore Canyon Trough area, Mid-Atlantic OCS: U.S. Geolcrical Survey Open-File Report 79-1159, 118 p.

Applin, P. L., 1951, Preliminary report on burled pre-Mesozoic rocks in Florida and adjacent states: U.S. Geolorical Survey Circular 91, 28 p.

Arthur, M. A., and Schlanger, S. 0., 1979, Cretaceous "oceanic anoxic events" as causal factors in development of reefreservolred giant oil fields: American Association of Petroleum Geologists Bulletin, v. 63, p. 807-885.

Ascoli, Piero, 1976, Foraminiferal and ostracod biostratigraphy of the Mesozoic-Cenozoic, Scotian Shelf, Atlantic Canada: Maritime Sediments Special Publication 1, pt. B, p. 653-677.

Baker, D. R., 1972, Organic geochemistry and geological interpretations, in Billings, G. K., Garrels, R. M., and Leris, J. E., Papers on low-temperature geochemistry: 
Journal of Geological Education, v. 20, p. 221-224.

Bayer, K. C., and Mattick, R. E., 1980, Geologic setting, in, Mattick, R. E., and Hennessy, J., eds., Structural framework, stratigraphy, and petroleum geology of the area proposed for $0 i 1$ and Gas Lease Sale No. 49 on the U.S. Atlantic Continental Shelf and Slope: U.S. Geological Survey Circular 812 [in press].

Bebout, J. W., and Lachance, D. J., 1979, Depositional environments, in Amato, R. V., and Simonis, E. K., eds., Geologic and operational summary, CosT No. B-3 we11, Baltimore Canyon Trough area, Mid-Atlantic OCS: U.S. Geological Survey Open-File Report 79-1159, p. 40-48.

Berger, W. H., 1974, Deep-sea sedimentation, in Burk, C. A., and Drake, D. L., eds., The geology of continental margins: New York, Springer Verlag, p. 213-241.

1976, Blogenous deep-sea sediments, in Riley, J. P., and Chester, R., eds., Treatise on chemical oceanography: London, Academic Press, p. 265-388.

Berggren, W. A., and van Couvering, J. A., 1974, The late Neogene--Biostratigraphy, geochronology and paleoclimatology of the last 15 million years in marine and continental sequences: Palaeogeography, Palaeoclimatology, Palaeoecology, v. 16, p. 1-216.

Blow, W. H., 1969, Late middle Eocene to Recent planktonic foraminiferal blostratigraphy, in Proceedings of the First International Conference on Planktonic Microfossils, Geneva, 1967: Lelden, Bri11, v. 1, p. 199421.

Blumer, M., 1967, Hydrocarbons in digestive tract and liver of a basking shark: Science, v. 158, p. 1463-1464.

Blumer, M., Robertson, J. C., Gordon, J. E., and Sass, J., 1969, Phytol derived $\mathrm{C}_{19} \mathrm{di}-$ and triolefinic hydrocarbons in marine zooplankton and fishes: Biochemistry, v. 8, p. 4067-4074.

Bramlette, M. N., and Wilcoxon, J. A., 1967, Middle Tertiary calcareous nannoplankton of the Cipero section, Trinidad, W.I. in Tulane Studies: Geology, v. 5, no. 3, p. 93-131.

Brown, P. M., Miller, J. A., and Swain, F. M., 1972, Structural and stratigraphic framework and spatial distribution of permeability of the Atlantic Coastal Plain, North Carolina to New York: U.S. Geological Survey Professional Paper 796, $79 \mathrm{p}$.

Bujak, J. P., and Williams, G. L., 1977, Jurassic palynostratigraphy of offshore eastern Canada, in Swain, F. M., ed., Stratigraphic micropaleontology of Atlantic basin and borderlands: New York, Elsevier, p. 321-341.
Bukry, David, 1971, Cenozolc calcareous nannofossils from the Pacific Ocean: San Diego Soclety of Natural History Transactions, v. 16, p. 303-327.

1973, Low-latitude coccolith biostratigraphic zonations, Edgar, N. T., Saunders, J. B., and others, eds., Inttial reports of the Deep Sea Drilling Project, v. 15: Washington D.C., U.S. Government Printing office, p. 685-703.

1975, Coccolith and silicoflagellate stratigraphy, northwestern Pacific Ocean, Deep Sea Drilling Project, Leg 32, Larsen, R. L., Moberly, R., and others, eds., Inftial reports of the Deep Sea Drilling Project, v. 32: Washington, D.C., U.S. Government Printing office, p. 677-692.

Bukry, David, and Bramlette, M. N., 1969, Coccolith age determinations, Leg 1, Deep Sea Drilling Project, Ewing, W. M., Worzel, J. L., and others eds., Initial reports of the Deep Sea Drilling Project, v. 1: Washington D.C., J.S. Covernment Printing office, p. 369-387.

Bush, P. R., 1970, A rapid method for the determination of carbonate carbon, and organic carbon: Chemical Geology, v. 6, p. 59-62.

Bybe11, L. M., 1975, Middle Eocene calcareous nannofossils at Little Stave Creek, Alabama: Tulane Studies in Geology and Paleontology, v. 11, no. 4, p. 17i-252.

Carlson, G. R., 1979, Selsmic velocity and data and correlation, Amato, R. V., and Simonis, E. K., eds., Geological and operational summary, COST No. I-3 well, Baltimore Canyon Trough area, Mid-Atlantic OCS: U.S. Geological Survey Open-File Report 79-1159, p. 49-56.

Claypoo1, G. E., Love, A. H., and Maurhan, E., 1978, Organic geochemistry, incipient metamorphism, and ofl generation in black shale members of Phosphoria Formation, Western Interior United States: American Association of Petroleum Geologists Bulletin, v. 62, p. 98-120.

Claypool, G. E., Lubeck, C. M., Baysinger, J. P., and Ging, T. G., 1977, Organic geochemistry, Scholle, P. A., ed., Geological studies on the CosT No. B-2 well, United States South Atlantic Outer Continental Shelf area: U.S. Geological Survey Circular 750, p. 46-59.

Claypool, G. E., and Reed, P. R., 1976, Thermalanalysis technique for soirce-rock evaluation--Quantitative estimete of organic richness and effects of 11thologic variation: American Association of Petroleum Geologists Bulletin, v. 60, p. 608-612.

Cooper, W. W., and Shaffer, B. L., 1976, Nannofossil biostratigraphy of the Bossier Shale and the Jurassic-Cretaceous boundary: Gulf Coast Association of 
Geological Socleties, Transactions, v. 26, p. 178-184.

Core Laboratories, Inc., 1979, Geochemical service report--Atlantic COST B-3, Baltimore Canyon, U.S.A. 3: Dallas, Texas, 200 p. Available for public inspection at the U.S. Geological Survey, Conservation Division, Eastern Region office, $1725 \mathrm{~K}$ Street, N.W., Washington D. C.

Cornet, Bruce, 1977, Palynostratigraphy and the age of the Newark Super-group: University Park, Pennsylvania, Pennsylvania State University, Ph. D. thesis, $505 \mathrm{p}$.

Crawford, Diane, 1978, East Coast 78--a year of inftiation: offshore Journal, $v \cdot 38$, no. 13, p. 82-87.

Diester-Haass, L., 1978, Sediments as indicators of upwelling, in Boje, R., and Tomczak, M., eds., Upwelling ecosystems: New York, Springer Verlag, p. 261-281.

Drake, C. L., Ewing, M., and Sutton, G. H., 1959, Continental margins and geosynclines-The east coast of North America north of Cape Hatteras, in Ahrens, L. H., and others, eds., Physics and chemistry of the Earth, v. 3: London, Pergamon Press, p. 110-198.

Emery, K. 0., and Uchup1, Elazar, 1972, Western North Atlantic Ocean--Topography, rocks, structure, water, Iffe, and sediments: American Association of Petroleum Geologists Memoir 17, 532 p.

Espitalie, J., Laporte, J. L., Madec, M., Marquis, F., Leplat, P., Paulet, J., and Boutefeu, A., 1977, Methode rapide de caracterisation des roches meres de leur potentiel petrolier et de leur degre d'evolution: Reviews Institute Francais Petrol, v. 32, p. 23-42.

Evans, Robert, 1977, Origin and significance of evaporites in basins around Atlantic Margin: American Association of Petroleum Geologists Bulletin, v. 61, no. 5, p. 783.

Ewing, J. I., and Ewing, Maurice, 1959, Seismicrefraction measurements in the Atlantic Ocean basin, in the Mediterranean Sea, on the Mid-Atlantic Ridge, and in the Norwegian Sea: Geological Society of America bulletin, v. 70, p. 291-318.

Falvey, D. A., 1974, The development of continental margins in plate tectonic theory: Australian Petroleum Exploration Association Journal, v. 14, p. 95-106.

Folger, D. W., Dillon, W. P., Grow, J. A., Klitgord, K. D., and Schlee, J. S., 1979, Evolution of the Atlantic Continental margin of the United States, in Talwan1 M., Hay, W., and Ryan, W. B. F., eds., Deep drilling results in the Atlantic Ocean-Continental margins and paleoenvironment: American Geophysical Union, Maurice Ewing Series 3, p. 87-108.

Gartner, S., 1977, Nannofoss11s and biostratigraphy--An overview: EarthSclence Reviews, v. 13, p. 227-250.
Gelp1, E., and Oro, J., 1968, Gas chromatographic-mass spectrometric analysis of isoprenoid hydrocarbons and fatty actds in shark liver oil products: Journal of the American $0 i 1$ Chemists Society, v. 45, p. 144-147.

Gehman, H. M., Jr•, 1962, Organic matter in 1imestones: Geochimica et Cosmochimica Acta, v. 26, p. 885-897.

Gibson, T. G., 1967, Stratigraphy and paleoenvironment of the phosphatic Miocene strata of North Carolina: Geological Society of America Bulletin, v. 78, p. 631649.

Given, M. M•, 1977, Mesozolc and early Cenozoic geology of offshore Nova Scotia: Bulletin of Canadian Petroleum Geology, v. 25, p. 63-91.

Gradstein, F. M., Williams, G. L., Jenkins, W. A. M., and Ascol1, P., 1975, Mesozoic and Cenozolc stratigraphy of the Atlantic Continental Margin, eastern Canada: Canadian Society of Petroleum Geologists Memoir 4, p. 103-131.

Grow, J. A., Bowin, C. 0., and Hutchinson, D. R., 1979, The gravity fleld of the U.S. Atlantic continental margin: Tectonophysics, v. 59, p. 27-5\%.

Grow, J. A., Dillon, W. P., and Sheridan, R. E., 1977, Diapirs along the continental slope off Cape Hatteras: Society of Exploration Geophysics, Abstracts w1th Programs, 47th Annual Convention, Calgary, 19-22 Sept 1977, p. 51.

Grow, J. A., and Klitgord, K. D., 1980, Structural framework, in Mattick, R. E., and Hennessy, J., eds., Structural framework, stratigraphy, and petroleum geology of the area proposed for 011 and Gas Lease Sale No. 49 on the T.S. Atlantic Continental Shelf and Slove: U.S. Geological Survey Circular 812 [in press].

Grow, J. A., Mattick, R. E., and Schlee, J. S., 1979, Multichannel selsmic derth sections and interval velocities over outer Continental Shelf and upper Continental Slope between Cape Hatteras and Cape Cod, in Watkins, J. S., Montadert, L., and Dickerson, P. W., eds., Genlogical and geophysical investigations of continental margins: American Association of Petroleum Geologists Memolr 29, p. 65-83.

Grow, J. A., and Mark1, R. G., 19i7, IPOD-USGS multichannel seismic reflection profile from Cape Hatteras to the Mid-Atlantic Ridge: Geology, v. 5, p. 625-630.

Hardenbol, J., and Berggren, W. A., 1978, A new Paleogene numerical time scale: American Association of Petroleum Geologists, Studies in Geology No. 6, p. 213-234.

Hathaway, J. C., Schlee, J. S., Poag, C. W., Valentine P. C., Weed, E. G. A., Bothner, M. H., Kohout, F. A., Manhoim, F. T., Schoen, R., Miller, R. E., and Schultz, D. M., 1976, Preliminary summary of the 1976 
Atlantic Margin Coring Project of the U.S. Geological Survey: U.S. Geological Survey Open-File Report 76-844, 217 p.

Hathaway, J. C., Poag, C. W., Valentine, P. C., Miller, R. E., Schultz, D. M•, Manheim, F. T., Kohout, F. A., Bothner, M. H., and Sangrey, D. A., 1979, U.S. Geological Survey core drilling on the U.S. Atlantic Shelf: Sclence, v. 206, no. 4418, p. 515527.

Hubert, J. F., Reed, A. A., Dowdall, W. L., and Gilchrist, J. M., 1978, Guide to the redbeds of central Connecticut: Society of Economic Paleontologists and Mineralogists, Eastern section, 1978 Field Trip Guidebook, $129 \mathrm{p}$.

Hunt, J. M., 1961, Distribution of hydrocarbons in sedimentary rocks, in Hanson, W. E., Symposium on the chemical approaches to the recognition of petroleum source rocks: Geochimica et Cosmochimica Acta, v. 22, p. 37-49.

1974, Hydrocarbon and kerogen studies, in van der Borch, C. C., and others, eds., Inttial reports of the Deep Sea Drilling Project, v. 22: Washington D.C., U.S. Government Printing office, p. 673-675.

International Blostratigraphers Inc., 1979, Blostratigraphy of the $\operatorname{cosT} B-3$ Baltimore Canyon we11: Houston, Texas, International Blostratigraphers Inc., 25 p. Avallable for public Inspection at the U.S. Geological Survey, Conservation Division, Eastern Region office, $1725 \mathrm{~K}$ Street, N. W., Washington, D.C.

Jansa, L. F., and Wade, J. A., 1975, Geology of the continental margin off Nova Scotia and Newfoundland, in van der Linden, W. J. M., and Wade, J. A., eds., Offshore geology of eastern Canada, v. 2, Regional geology: Geological Survey of Canada Paper 74-30, p. 51-150.

Keen, C. E., and Keen, M. J., 1974, The continental margins of eastern Canada and Baffin Bay, in Burk, C. A., and Drake, C. L., eds., The Geology of Continental Margins: New York, Springer Verlag, p. 381-389.

Keen, M. J., 1969, Magnetic anomalies off the eastern seaboard of the United States--A possible edge effect: Nature, v. 222, p. 72-74.

Killingley, J. S., and Berger, W. H., 1979, Stable 1sotopes in a mollusk shell-Detection of upwelling events: Science, v. 205, p. 186-188.

Kling, S. A., 1978, Radiolaria, in Haq, B. U., and Boersma, A., eds., Introduction to marine micropaleontology: New York, Elsevier, p. 203-244.

Klitgord, K. D., and Behrendt, J. C., 1979, Basin structure of the U.S. Atlantic margin, in Watkins, J. S., Montadert, L., and Dickerson, P. W., eds., Geological and geophysical investigations of continental margins: American Association of Petroleum Geologists Memoir 29, p. 85-112.

Klitgord, K. D., and Grow, J. A., in press, Jurassic seismic stratigraphy and basement structure of the western Atlantic Nagnetic Quiet Zone: American Association of Petroleum Geologists Bulletin.

Lachance, D. J., 1979, Lithology, in Amrto, R. V., and Simonis, E. K., eds., Geoloric and operational summary, COST No. B-3 we11, Baltimore Canyon Trough area, Mid-Atlantic OCS: U.S. Geological Survey Op:n-File Report 79-1159, p. 13-20.

Lancelot, Y., and Selbold, E., 1978, The evolution of the central northeastern Atlantic-summary of results of DSDP Leg 41 , in Lancelot, Y., Selbold, E., and others, Initial reports of the Deep Sea Drilling Project, v. 41: Washington, D.C., U.S. Government Printing office, p. 1215-1245.

Loeblich, A. R., and Tappan, Helen, 1966, Annotated index and bibliography of the calcareous nannoplankton: Phycolocia, v. 5, p. 81-216.

Malinowsk1, M. J., 1979, Core descriptions and analyses, in Amato, R. V., and Simonis, E. K., eds., Geological and operational summary, CoST No. B-3 well, Baltimore Canyon Trough area, Mid-Atlantic OCS: U.S. Geological Survey Open-File Report 79-1159, p. 66-80.

Matt1ck, R. E., Foote, R. Q., Weaver, N. L., and Grim, M. S., 1974, Structural framerork of the U.S. Atlantic outer Continental Shelf north of Cape Hatteras: American Association of Petroleum Geologists Bulletin, v. 58, no. 6, pt. 2, p. 11791190 .

Mattick, R. E., Girard, 0. W., Jr., Scholle, P. A., and Grow, J. A., 1978, Petroleum potential of the U.S. Atlantic slope, rise, and abyssal plain: American Association of Petroleum Geologists Bulletin, v. 62, p. 592-608.

Mattick, R. E., Perry, W. J., Jr., Robbins, E. J., Rhodehame1, E. C., Weed, E. G. A., Taylor, D. J., Krivoy, H. L., and Bayor, K. C., 1975, Sediments, structural framework, petroleum potential, envirormental conditions, and operational considerations of the United States Mid-Atlantic outer Continental Shelf: U. S. Geological Survey Open-File Report 75-61, 143 p.

Mattick, R. E., Schlee, J. S•, and Bayer, K. C., in press, The geology and hydrocarbon potential of the Georges Banks-Baltimore Canyon area, in Kerr, J. W., ed., Geological atlas of the North Atlantic borderlands: Canadian Society of Petroleum Geologists.

McIver, N. L., 1972, Cenozolc and Mesozoic stratigraphy of the Nova Scotla Shelf: Canadian Journal of Earth Sciences, v. 9, p. 54-70. 
geologic history of the passive margin off New England the Canadian martitime provinces: Tectonophysics, v. 59, p. 5369.

Vail, P. R., Mitchum, R. M., Jr., and Thompson, S., III, 1977, Global cycles of relative changes in sea level, in Payton, C. E., ed., Selsmic stratigraphy--Applications to hydrocarbon exploration: American Association of Petroleum Geologists Memoir 26, p. 83-97.

Valentine, P. C., 1977, Nannofossil blostratigraphy, in Scholle, P. A., ed., Geological studies on the COST No. B-2 well, U.S. Mid-Atlantic Outer Continental Shelf area: U.S. Geological Survey Circular 750, p. 37-40. 1979, Calcareous

nannofossil biostratigraphy and paleoenvironmental interpretation, in Scholle, P. A., ed., Geological studies of the COST No. GE-1 we11, U.S. South Atlantic Outer Continental Shelf area: U.S. Geological Survey Circular 800 , p. 64-70.

van Hinte, J. E., 1976a, A Jurassic time scale: American Association of Petroleum Geologists Bulletin, v. 60, p. 489-497.

1976b, A Cretaceous time scale: American Association of Petroleum Geologists Bulletin, ve 60 , p. 498-516.

1978, Geohistory analysis--Application of micropaleontology in exploration geology: American Association of Petroleum Geologists Bulletin, v. 62, no. 2, p. 201222.
Vassoyevich, N. B., Korchagina, Yu. I., Lopatin, N. V., and Chernyshev, V. V., 1970, Glavanaya faza nefteobrazovaniya [Principal phase of ofl formation]: Moskovskogo Universiteta Vestnik, Series 4, Geologil, v. 24, no. 6, p. 3-27. English translation in International Geology Review, v. 12, no. 11 , p. 1276-1296.

Von Rad, U., and Einsele, G., 1980, MesozoicCenozolc subsidence history palesbathymetry of the northwest African continental margin (Aaiun basin to DSDP Site 397): Royal Soclety of London, Philisophical Transactions, A, Mathematical and Physical Sclences, V. 294, no. 1409.

Weed, E. G. A., Minard, J. P., Perry, W. J., Rhodehame1, E. C., and Robbin, E. I., 1974, Generalized pre-Plefstocene geologic map of the northern United States Atlantic continental margin: U.S. Geological Survey Miscellaneous Geological Investigations Series Map I-861, scale 1:1,000,000.

Wilcoxon, J. A., 1972, Jpper Jurassic-Lower Cretaceous nannoplankton from the western North Atlantic basin, in Hollister, C. D., Ewing, J. I., and others, eds., Initial reports of the Deep Sea Drilling Project, v. 11: Washington, D.C., U.S. Government Printing office, p. 427-457.

Williams, G. L., 1975, Dinoflagellate and spore stratigraphy of the Mesozoic-Cenozolc, offshore eastern Canada: Geological Survey of Canada Paper 74-30, v. 2, p. 107-161. 